


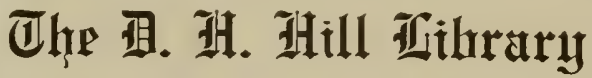

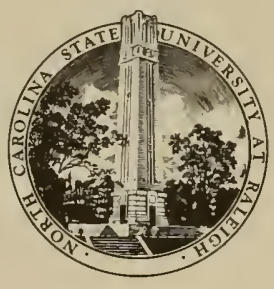

Nurth Caralina \$tate Zniuersity QK9 C95 
THIS BOOK IS DUE ON THE DATE INDICATED BELOW AND IS SUBJECT TO AN OVERDUE FINE AS POSTED AT THE CIRCULATION DESK.

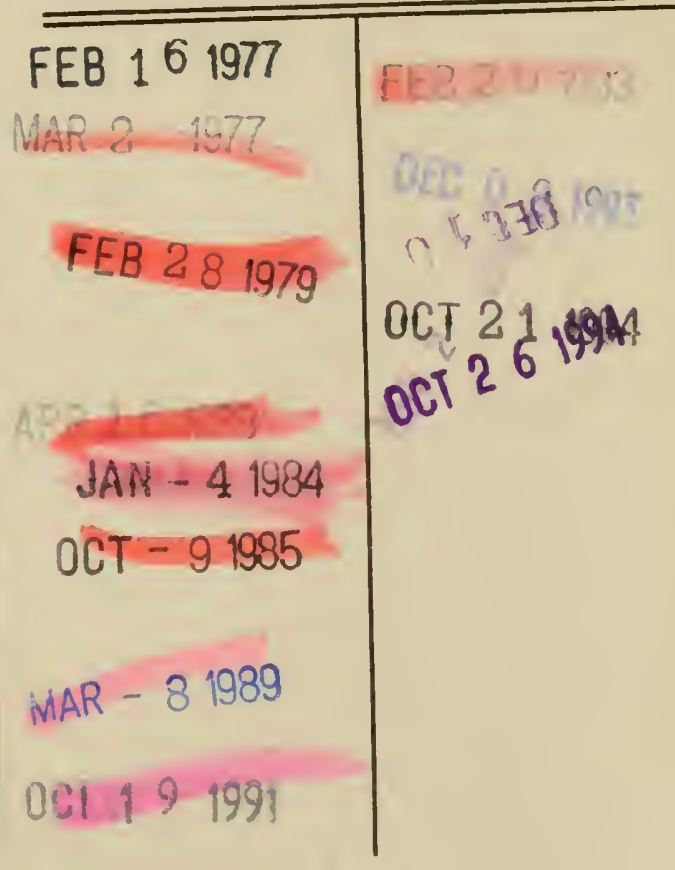







\title{
A. DICTIONARY
}

oF

\section{BOTANICAL TERMS}

\author{
BY \\ A. A. CROZIER
}

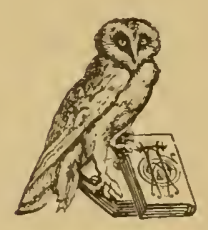

NEIV TORK

HENRY HOL'T AND COMPANY

1892 
Copyright, 1892,

BY

HENRY HOLT \& CO. 


\section{PREFACE.}

IT is now nearly twenty years since an English dictionary of botanical terms was published, and the development of botany during that time has brought into use many new terms and led to the abandonment of some of those which were formerly employed. The present work, though larger than any of its predecessors, is therefore wanting in certain terms which are found in the earlier botanical dictionaries. A few obsolete terms, howerer, which occur in standard botanical literature are retained and marked as such. The scope of this dictionary is nearly the same as that of its predecessors, except that it is broader on the side of agriculture and horticulture, as it aims to include all technical terms applied to plants both by botanists and others. Very many of the newer terms are from the German botanists, to whom we owe by far the greater part of modern structural and physiological botany. 'These terms, particnlarly, include an unfortunately large number of synonyms, which seem to be a necessary result of active research by independent workers in the same fields. With few exceptions, no definition is repeated, all approved synonyms being brought together under one term. Where a choice existed this has permitted the preferable term alone to be defined. No obsolete or wholly undesirable synonyms, howerer, accompany the definitions, and such of these as occur in alphabetical order have usually been admitted only to refer 


\section{PREFACE.}

the reader to the proper term. The cross-references freely given to terms of similar and opposite meanings will be found useful in broadening the scope of the definitions.

I desire here to express my gratitude to various botanical friends for their contributions to this work, particularly to Dr. W. J. Beal, of the Michigan Agricultural College, who has revised the entire manuscript and improved many of the definitions; to Professor V. M. Spalding, of the University of Michigan, who has revised and corrected the terms relating to fungi; to Mr. F. C. Newcombe for aid upon the terms applied in karyokinesis; and to Professor L. H. Bailey, of Cornell Unirersity, for advance proof-sheets of his glossary of horticultural terms.

The marking of the pronunciation was begun by Mr. B. Pickman Mann, of Washington, D. C., and completed by Mr. F. P. Jordan, of the University of Michigan. In their work Webster's dictionary was mainly followed as authority.

ANm ARbor, Mich., January, 1892. 


\section{SIGNS AND ABBREVIATIONS.}

(1).... anuนal.

(2)... biennial.

2f....peremial.

o....staminate.

\&....pistillate.

$\Varangle \ldots$ perfect.

$\infty$...numerous; more than twenty when applied to stamens.

?.....doubt.

!.....certainty. Indicates that the author has seen the specimen in question.

n. sp. new species. Used only with the first printed description.

Eu...the Greek word "well," sometimes written after a species to indicate that it is certainly a well-defined species, not a variety.

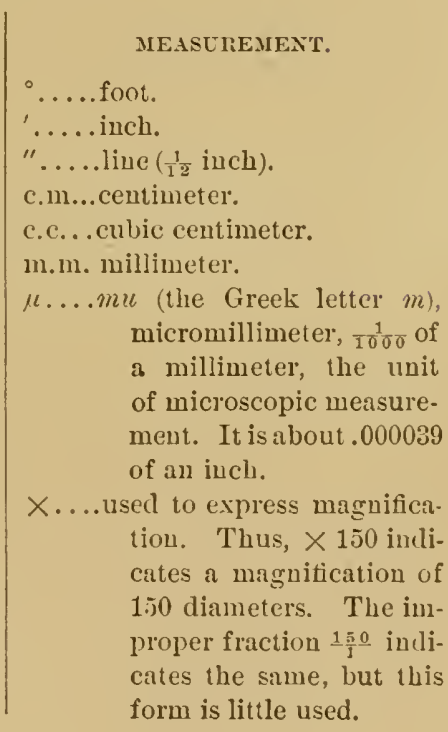





\section{A DICTIONARY}

\section{OF BOTANICAL TERMS.}

A, prefixed to words of Greek origin often signities absence, as cipèt'üloǔs, without petals. Before a vowel it is clinged to AN, as ănün'theroǔs, without anthers.

$\check{\mathrm{A}} \breve{\mathrm{A} X} \breve{\mathrm{I}} \mathrm{AL}$, out of the axis. See EXCENTRIC.

ABBRĒ VIĀTED, shorter than an adjoining organ, or one with which it is compared.

ABĚR'RANT, differing widely from the usual form or struc. ture; as: the Fnmariacex have been regarded as an aberrant group of Papaveracex.

ĂBĬŌG ĚN'ESĬS, see SPONTANEous Generation.

ĂBJĚ $€^{\prime}$ TION, throwing off with force, as spores or seeds.

ÁBJOINT', to separate at a joint.

ÁBJǓNCTION, the separation of one part from another; delimitation. Compare ABstric. TION.

ÁBNÔR'MAL, differing from the "usual structure or condition.

ĂBŌRĬG' INNAL, see INDIGENous. ÁBÔR'TION, the non-formation or imperfect formation of an organ, so that it does not per- form its usual function. Com pare Suppression, Degener. ation, Atrophy.

ȦBô'TǏVE, imperfect, or wanting. See OBsolete.

ĂBRŬPT', terminating suddenly, as a leaf which ends without a taperiug extremity, a compound leaf without a terminal leatlet, or a stem which is sharply beut.

ĂBRŬPT'LY̌ ĂCŪ'MǏNĀTE, having a broad extlemity from which a point arises.

ĂBRǓPT'LY̌ PǏN'NĀTE, pinnate without a terminal leatlet, and usually with an even number of leaflets. There may be a terminal point or tendril; even pinnate; equally pinuate. Compare IMPARIPINNA'TE.

ĂBSÇĬS' SION, cutting off sharply, as the separation of the frustules of diatoms. Compare A BSTRICTION.

Ă B SÇǏSS LĀY'ER, a layer of cells formed by renewed cell-division in the base of the leaf. stalk in autumn, the formation of which permits the fall of the leaf. 
ÁBSôRP TION, the method by which Huids enter the plant. Sec Osmose and Imbibition.

ÁBSTRĬC'TION, the separation of one part from suother by constriction and the formation of a septum. Applied especially to the separation of spores from their hyphæ. Compare AB. scIssion aud ABronction.

ĂCĂL'Y̌C̆INE, without calyx; acalycinous.

ĂCĂLY̌Ç ǏNOǓS, see ACALYCINE.

ĂCĂN'THA (pl. Àcăn'thæ), a thor'n, spine, or prickle.

ĂCĂNTHĀ'ÇEOǓs. having thorns, spines, or prickles.

ĂCĂNTHÖCÄR'POǓs, having the fruit furnished with spines or prickles.

ĂCĂNTHŎC LĂDOǓs, having spiny brauches.

ĂCÁNTHǑPH ǑROǓs, bearing prickles, spines, or thorus.

ĂCĂNTHǑP ŎDOǓs, having the petiole or pedicel furuished with spines or prickles.

ĂCÄR'POǓS, not produciug fruit.

ĂCA ULĚS CENÇE, aL abnormal suppression of the stem.

ĂCA ULĚS'CENT, having only a very short aerial leaf-bearing sten, apparently none, as in the dandelion; acauline; acaulose; acaulous.

ĂCẠU'LINNE, sce ACAULESCENT.

ÁCAUU'LIS, SEe ACACLESCENT.

ĂCAU'LŌSE, see ACAULESCENT.

ĂCAUU LOǓS, SEe ACAULESCENT.

ÁEÇES'SǑRY̆, additional to the usual number, or accompany. ing something else; supernumerary. Said of the additional buds when more than one occur in an axil; applied to the border of the apothecium in lichens when of a diflerent substance or color from the disk.

ĂEÇES'SǑRY̌ BUDS, also called secondiury buds and supernumerary buds; the additional buds when more than one occur in or near the axil, as in the butternut.

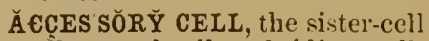
of a guard-cell; subsidiary cell.

ĂECESSŎRY FRUIT, one in which some arditional part or parts is associated with the matured ovary, as in the wintergreen, Gaultheria procumbens; authocarpous fruit. The term is not applied to fruits with an adherent calyx-tube, as the apple and currant. Compare Aggregate Fruit and COLLECTIVE Fruit.

Ă€ÇES'SǑRY̌ GǑNǏD'ǏÁ, gonidia? formations in some species of Mucorini in addition to the typical kind.

ǍEÇĬDĔN'TÁL, see ADYENTITIOUS.

ĂCCŎMMODÁ'TION, see ADAPTA. TION.

ĂCCRĔS'ÇENT, increasing in size after thowering; - applied to parts accessory to the fruit, as the calyx of Physalis.

ĂCCRẼTE', grown together in auy mauner.

ÁCCR $\overline{\mathbf{E}}^{\prime}$ TION, the glowing of one thing to another ; growth by addition of particles to the ont. side.

ĂCCǓM'BENT, lying upon or against another body, as the edge of the cotyledons against the caulicle in some Crucifere. Compare InCUMBENT.

ĂCËPH'ǍLOUัS, headless; said of an ovary when the style is attached to some other part than the summit.

ÁÇERŌSE', narrow, stiff, and 
pointed, like the leaves of the tir. Intermediate in form between Acicular and Subulate.

ĂÇÈR'VĀTE, growing in heaps or cluster's; coacervate.

ĂÇẼR'VŪLǓs (pl. Ăçẽr'vīūī), a small lieap, as of spores.

ÁCETĂBŪ'LIFŎRM, deep saucelshaped, with a broad concave bottom and nearly upright sicles. Compare Cótyliform.

ĂCETÁ'RǏOǓS, used for salads.

ĂÇ'ETŌSE, sour; ateiıl.

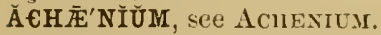

ĂEH新 NŎCÄRP, any simple dry indehiscent fruit. (Masters.)

Ă€HEI'LǍRY̌, destitute of a labellum, as some orchids.

Ă€HĒNE', see ACHENIUM.

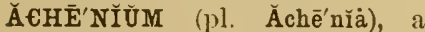
small, dry, indehiscent, oneseeded seed-like fruit or carpel in which the covering does not adhere to the seed, as in the sinflower or buttercup; achanium; achene; akene. Compare Calzopsis, UTHICLE, CYPSELA.

Ă€HĒNŌ'DǏ́M, see CREMOCARP.

Ă€HLĂMY̌'DEOÜs, destitute of calyx and corolla.

ÁEHROMĂT'ÍC, not reaclily colored by the usual staining agents.

ĂEHRŌMĂTǏN, the basic substance of the nuclens, less highly colored by staining agents than the rest.

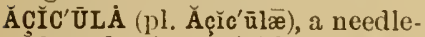
shaped spine, prickle, or other body.

ÁC̆́C'ÜLAR, slender needle- or bristle-shaped, as the leaves of most pines ; aciculate; aciculiform; aciform. Compare ACERose.

ĂČIC'ŪLĀTE, see ACICULAR.

ÁÇIC'ÚLĀTED, marked by fine grooves, as if scratched with i needle. Fincr than striate, and not necessarily parallel.

ĂÇİC'ÜLIF́̂RM, see ACICULAR.

$\breve{A}^{\prime} C ̧ \bar{I} \bar{E} S$, an edge.

ĂÇ'IFÔRM, sce ACICL'LAR.

ĂÇIN $\bar{A}$ ÇEOǓS, full of kernels. (Rare.)

ĂÇĬNĂC̣'ÍFÔRM, sc y mit a r shaped;-luaving one edge thin and convex, and the other thick and straight or concave, like many bean-pods.

ĂÇ'INNE, one of the succulent carpels of a fruit like the raspberry; acimus. (Origiually Acinus meant : bunch of grapes or similar fruit, as the currant, aud later the term was applied to one of the berries of such a bunch and to the seeds of the grape.)

ĂÇĪNōSE', consisting of granular bodies somewhat resembling grape-seed. Ilore rarely, resembling a gripe-berry or buuch of grapes.

ĂC̣'ĨNŬS (pl. Åç'ĩnī), see AcrNE.

ĂCǑTY̌LẼD'ǑNOǓS, destitute of cotyledons, as Cuscuta.

ÁCRĂMPHǏB'RYัOǓs, said of pliuts whose growth is not confined to the apex, i.e., which produce lateral as well as terminal buds. (Rare.) Compare. ACrogenous.

ĂCRŎB'RY̌OǓS, see ACROGENOU's. ĂCRŏCÂR'POǓS, having trrminal fructification. Used chiefly in mosses. Compare CladoCARPOUS.

ĂCRǑG'ENOǓS, growing chietly at the apes, as the stem of ferms; produced at the apex of a filament, as the spores of some fungi.

ĂCRŎG'Y̌NOǓS, having the stem terminated by archegonia ol 
other female organs. Compare AnACROGYNous.

ĂCRŎP'ĚTĂL, produced in succession toward the apex; in the direction of the summit; basifugal; ceutripetal (wheu applied to the order of intlorescence only). Compare BasipETAL.

ĂcRŏscŏP'Ǐc, facing the apex. Compare Basiscopic.

AC'RǑsPIRE, an old name for the plumule of a grain in ger. mination.

ÁC'RŏSPōRE, a spore borue at the summit of a filament.

ÁCTǏNŏMÔR'PHǏC, regular and polysymmetrical, as the flowers of radish, i.e., capable of bisection in two or more planes iuto similar halves. Compare ZYgomonPHic.

ĂCTǏNǑMÔR'PHOǓS, see ACTINoMORPIIC.

AC'TİVE, in a growing condition; opposed to Dormant.

ĂCŨ'L $\bar{U}^{\prime} \bar{A} T E$, having prickles; prickle-pointed; aculeated.

ĂCŪ'LEǑLĀTE, Laving small or few prickles.

ÁCŪ'LEǓS (pl. Ăcūleī), see PRICKLE.

ĂCU'MINĀTE, ending in a prolonged tapering point.

ÁCŪ'MÍNōsE, having a sharp or tapering point; somewhat acuminate. (Rare.)

ÁCŪMIN' ŪLĀTE, having a small acuminate point.

ĂCŪTE', ending in a distiuct angle, but not prolonged.

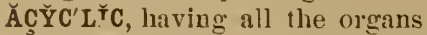
of a flower iu a continuous spiral. Compare HeMicrclic aud C'YCLIC.

ĂDĂPTÁ'TION, the modification of a plant to better fit it for surrounding conditions, or of an organ for a particular function; accommodation. Com. pare Metanionpiosis.

ĂDĚL'PHĬÁ, (pl. Áděl'phīæ), a collection of stamens united by their filiments. Compare Phalanix.

ĂDĚL'PHOǓs, having the stamens united by their filaments in an adelphia or bundle.

ĂDẼN'ÍFÔRM, gland-shaped; adenoid.

ĂDĚN'ǑPHŌRE, a stalk supportiugr a gland.

ĂDENǑPH'ǑROǓS, gland-bearing.

ĂDENŎPHY̌L'LOǓs, having on the leaves glaucls, or gland-like spots or tubercles.

ĂDENOัP'ǑDOǓs, having glands or gland-like tubercles on the petioles.

ĂDENŌSE', gland-like, or bearing gliuds; adenoid; adenous.

ĂD'ENOǓS, see ADENOSE.

$\widetilde{A D}$ ESMY, the separation of parts usurlly joined. Compare Chorisis, Dialysis, Fission.

ĂDGLŪ'TǏnĀTE, see AgGLUTINATE.

ÁDHE' RENT, attached or growing to an organ or body of a ditiferent nature, as the calyx to the ovary. The parts may or may not have growu together from the first. Compare ConeREN' and ADNATE.

ĂDHE'sION, the sticking or growing together of organs of a different uature, as a leaf to the stem. It implies a union of parts which in most other plants or in a younger state of the same plant are separate.

ĂDNĂS'ÇENT, growing to or upon something else: as, "moss is an rduascent plant."

ĂD'NĀTE, said of parts of a dif- 
ferent uature which are grown together from the tirst, or over their whole surface or length. (Compare Connate.) Applied to an anther, it indicates that it is attached throughout its length to the npper or lower surfiace of the filament. Compare Insate. See Adheren't.

ÁDN'TION, the same as adhesion, but implying an earlier or more eomplete union.

ĂDPRĔSSED, see APPRESSED.

ĂDSÇĚN'DĔNT, see AscENDING. ÁDSÛR GENT, see ASCENDING.

ĂDUัN'CoŬS, crooked, twisted, or hooked. (Rire.)

ĂDVENTÍ'TIÓUS, out of the usual place, as buds on al leaf or at a distauce from in nole; growing spontaneously out of its native locality, but not fully established; adventive.

ĂDVĔN'TIVE, see ADVENTI TIOUS.

ĂD'VẼRSE, (1) opposite (rare); (2) directed toward or facing the main axis or other object. Compare A verse.

ĂDVẼRSǏFō'LĪATE, see ADVERSIFOLIOUS.

ÁDVẼRSIFF̄'LǏOǓs, having opposite leaves; adversifoliate.

承ǏD'ǏǑsPōRE, a spore produeed in an recidium.

画 shaper spore-case with its contents in certain Urediuex, in which the spores are produced serially from below; aceidium fruit.

ĀERĔN'CHY̌MÁ, tissue homologous with cork, with thin cellwalls atud large intercellular spaces, found in the stems of some marsh-plants, as Lythrum salicaria. It is supposed by Schenk, the author of the term. to serve for aeration. but by others it is regarded as floating tissue.

$\overline{\mathbf{A}} \overline{\mathbf{E}}^{\prime} \mathbf{R}$ I AL, growing in the air, not attached to the suil, as a para. site or epiphyte upon the top of some other plant.

ĀE'RĬĂL R00TS, those appearing above ground, whether they afterwards enter the ground or not, as the clingiug roots of the ivy and the brace-roots of Indian corn.

ĀERŌ'BĬ $\dot{A}$ (sing. Āerō'bium), organisms which thrive only in the presence of. air or free oxygeu. Applied in bacteria. Compare ANAERoBia.

ÁERǏǑBǏǑT'ǏC, thriving only in the prosence of air.

$\bar{A}^{\prime}$ ERǑCY̌ST, an olı name for ail'bladiler.

A'ERŎPHȲTE, see AIR-PLANT.

A'ERǑTRŏP'IC, seeking the air, as certain roots.

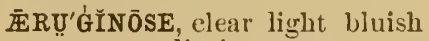
green; verdigris-green.

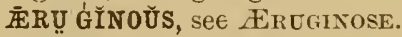

ESTĨ VĂL, see EsTIVAL.

Æ̌sSTIV $\bar{A}^{\prime} T I O N$, the arrangement of the floral organs in the bud; priefloration.

胥THA $\bar{A}^{\prime} L \check{I}$ Ŭ, a compound sporiferous body in Myxomycetes, formed from a large combina. tion of plismodia.

ĂFFÍN'ÍTÝ, true or near relation ship. Compare ANALogr and Hoyologr,

ĂGĂM'ÍC, destitute of sex. Formerly applied to all eryptogams.

ĂG' ÄMǑĠ̌̌N'ESǏs, asexnal reproduction of any kind. See Parthenogensis and ApogA.II.

ĂGĂM'ǑSPŌRE, a spore formed without fertilization; - a go- 
nidium or asexualle produced spore of any kind. (Rare.)

ĂG'ĂMOǓS, see AGAMIC.

ĂGGLǑM'ERĀTE, see ACGLOMERATED.

ĂGGLOัM'ERÃTED, clustered or crowded togetiner but not cohering, as the staminate flowers of pines.

ĂGGLU'TǏNĀTED, glued together. Compare ACCRETE.

ĂG'GREGĀTĚD, collected together but not cohering. About the same as Agglomerated.

ĂG'GREGĀTE FLOWERS, those with several in the same head, as in clover. The term excludes Compositre.

ĂG'GREGĀTE FRUIT, one in which distinct carpels of a single flower are crowded on the receptacle into one mass, as in the raspberry and magnolia; syncarp. Compure CoLLECTIVE FRUIT.

AGGREGA'TION, the condeusation of the protoplasu of a living cell, or of some of the contained proteids under stimulation: first observed in the tentacle cells of Drosera and subsequently produced in the cells of otlier plints by means of various basic substances

ĂGRǏCŬLT'URAL BOTANY, that branch of econonic botany which treats of weeds and cultivated plants. It inclucles the systematic study of such plants and their methods of reproduc tion, the laws of improvement and degeneration in plants, etc., also vegetable pathology in its application to cultivated plants.

đ̆GRǑSTǑG'RĂPHY̌, see AGROs. TOLOGX.

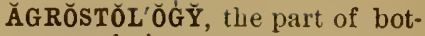
any relating to grasses.

ĂG'YัNOǓS, without pistils.

$\bar{A} I^{\prime} G R E T$, any feathery crown or tuft attached to the seed, as the coma of the milkweed or pappus of the thistle; aigrette; egret.

ĀIGRETTE', see AIGRET.

AIR-BLADDER, an organ filled with air for the purpose of floating the plant in water, as in the sea-weed Fucus; air-sac; air-cell.

AIR.CHAMBER, see STOMATIC Chamber and Air-Passage.

AIR-PASSAGE, an extended opening between the cells containing air, as in the stems of many water-plants; lacuna; air-chamber.

AIR-PLANT, a plant growing in the air detached from the soil, as certain orcliids; ærophyte. Generally applied only to epiphytic flowering plants.

AIR-PORE, see STOMA.

ĂKENE' see ACHENICM.

ẢLA் (pl. Ālæ)), see Wing.

ĂLĂBĂS'TRŬM, an old term for flower-bud.

$\bar{A}^{\prime} L A R$, (1) borne in the forks of a stem; (2) relating to or having wings. See Alate.

$\bar{A}^{\prime} L \overline{A T E}$, see WINGED.

$\bar{A}^{\prime} L \bar{L} T E-P I N^{\prime} N \bar{A} T E$, pinnate with a winged petiole.

ĂLBĚS'ÇENT, whitish; candicant.

ĂL'BĬCĂNT, see ALBESCENT.

ĂL'BǏNǏSM, see Chlorosis.

ĂLBI'NO, a plant or vuriety nearly destitute of chlorophyll, or of which the fruit is abnormally white or colorless.

ĂLBU' $M E N$, nutritive material in many seeds surrounding or 
adjoining the embryo, endo sperm or perisperm.

ĂLBŪ'MEN CRY̌STĂLS, see Cristalloids.

ÁLBŪ'MǏNOID, an organic sub stance containing nitrogen in its composition, as protoplasm; proteid.

ĂLBŪ'MÍNOǓS, furuished with albumen.

ĂLBÛR'NOǓs, haviug, consisting of, or pertaining to, albur. nutu.

ĂLBÛR'NǓM, sap-Wood; a somewhat distinct, usually lighter colored, outer zone of wood in many exogenous trees and shrubs.

ALĚCTŌ'RIOID, filiform, like the thallus of the genus Alectoria in lichens.

ALEU'RŌNE, proteine-grains which replace starch in the cotyledons or albumen of certain oily seeds.

ĂLGŎL'ŎGY̆, the part of botany relating to algæe.

ALǏF'EROǓs, having wings.

ĂL'ǏFôRM, wing-shaped.

ĂLĬG'EROǓS, see ALIFEROƯs.

ĂLLĂN'TOID, saltsage-shaped; botuliform; narrowly oblong; cylindrical with somewhat hemispherical terminations.

\section{ĂLLĂSSǑTǑN'ǏC MOVEMENTS,} a term applied by V ries to the movemeuts of miture organs, as the sleep of plants; movements of variation. Compare AuxoToNic Movenents.

ĂLLǏÁCEOǓS, having the odor or other qualities of the genus Allium, which includes the onion and garlic.

ĂLLI'ĂNÇE, see CoHoRT.

ĂLIŎG'ĂMOǓs, habitually crossfertilized.
ĂLLŎG'ǍMY̌, cross-fertilization. Compare Autogams.

ĂLLǑT'RŏPǏSM, appearance un. der an unusual form.

ĂLPĚS'TRǏNE, glowing on high mountains below the timber line, or on the tops of inferior mountains; mountainous.

ALPHǏTǑMÔR'PHOǓS, resem bling barley meal. said of certain fungi (Rare.)

ĂL PǏNE, growing on mountains above the timber-line.

ĂLTẼR'NĀTE, applied to leaves, indicates one at a node; ap plied to parts of the flower, in. dicates that the members of one whorl are placed opposite the intervals between the members of the next whorl.

ĂLTẼR'NĀTEL Y - P I N N' N Ā T E, pinnate with the pinnze or leat' lets alternating on opposite sides of the rachis.

ĂLTERNÄ'TION OF GENERA. TIONS, the growth of reproductive bodies into structures differing from that on which they were produced, to return after one or more generations to the original stage or form. 'Thus, the spore of ferns produces a small prothallus, and upon this sexual bodies are borne which after fertilization reproduce the original fern-plant. See Metagenesis.

ĂLUTT $\bar{A}^{\prime} \mathbf{C E O U} S$, of a pale brown color; resembling soft tanned skin in color or texture. (Rare.)

ÁL'VEǑLĀTE, deeply pitted so as to resemble boney.comb, like the receptacle of many Compositz; faveolate; favose.

ĂMBÍG'ENÚS, having the outer surface of the perianth resembling a calyx and the inner surface a corolla. 
ĂMBÍG'ŪoǓs, indistinct or doubtful, so that it caunot well be referred to any definite condi tion or place in a system of clas. sitication, as a bract which has nearly the appearance of an ordinary leaf, or a species which is doubtfully of higher rank than a variety, or one which it is difticult to determine into which of two genera it should be placed.

ĂMBÍP'ĂROǓS, producing two kinds, as a bud which produces directly both flowers and leaves.

AM'ENT, a slender spike of naked and usually separated flowers with imbricated scales or bracts; amentum: julus; catkin. Staminate aments are usually deciduous.

AMĚN'TÁ, pl, see AMENTUM.

ĂMENTA'ÇEOŬS, reseınbling, consisting of, pertaiuing to, or bearing aments; as an amentaceous inflorescence or plant.

ÁMĚNT'ǏFôRM, amentaceous; juliform.

ĂMĚN'TŬM (pl. Ăměn'tả), see AMENT.

ĂM'ǏDŎPLǍST, see LEUCOPLAST. ĂMMǑPH'ǏLOǓs, growing in sandy places.

$\breve{\mathbf{A}} \mathbf{M}^{\prime} \mathbf{N}$ Ǐs, the contents of the embryo-sıc betore the formation of the embryo. Seldom used.

ĂME'BOID, assuming various shapes, like the Amoba

ĂMÔR'PHOǓS, without definite form, structure, or position.

ĂMPHĂN'THǏŬM, see CLINANTHIUN.

ĂM'PHIASTER, a term for the combined nuclear spindle and cytasters in karyokinesis when the latter are present, which is rare iu plants. The term is also applied to the combined cytasters only.

AัMPHǏ'ǏOŬS, growing realily either in water or upon dry land.

ĂMPHǏB'RYัOǓS, growing by additions over the whole surface. ĂMPHĬCÄR'PǏC, producing two kiuds of fruit, either as regards form or period of ripening; amphicarpons. Compare HETERUCARPUES.

ĂMPHĬCÄR'POǓs, see AMPHICALPIC.

ĂMPHǏG'ĂMOǓS, see AGAMIC.

ĂMPHĬGÀS'TER, used by Benuett and Nurray for Amphigastrium.

ĂMPHĬGĂS'TRIẢ (sing. Amphigastrium), peculiar scale-like leives accompanying those of ordinary form as a third row upon the under side of the stem in certain Hepatica.

ĂMPHǏG'ĚNOǓS, growing on either surface of a leaf. Said chiefly of certain parasitic fungi.

ĂMPHǏSÄR'CA, any indeliscent fruit, hard and dry externally and pulpy within, as a gourd. (1Rare.)

ĂMPHǏSPẼR'MOUัS, closely investiug the sced so as to have the same form, as the ovary in Graminex.

ĂMPHǏT'RŎPAL, see AMPHITROPOUS.

ĂMPHIT'ROPOǓS, having the funiculus attached to the ovule or seed for half the distance between the chalaza and micropyle; semiauatropous; halfa n a tropous; half-inverted; hemitropous; heterotropous; transverse; amphitropal. Applied to the embryo it means culved so that both ends are brought close together. 
ÁM'PHǑRA, the lower division of a pyxis.

ĂMPLĚC'TĂNT, embracing or clasping, as tendrils, or the sheath of grasses.

ĂMPLĚX'ǏCA ULL, partially surrounding or clasping the stem, as the base of many leaves. Compare Sheathixg and PerFOLIATE.

ĂM'PLİĀTED, eularged, or mod̄erately dilated.

ĂMPŬL'LA், see BLADDER.

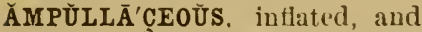
swelling ont loward the base like a bladder or short tlask. Compare LAgENIFORM.

ĂMÝG'DǍLINE, pertaining to or resembling the almoud.

ĂMY̌LA $\bar{A}^{\prime} C E O U ั S$, pertaining to, composed of, or resembling starch.

ĂMY̌LǑĞ́̌N'ESǏs, starch-formation.

AMY̌LŎG ĔN'ǏC, starch-forming. Applied to chlorophyll-granules and similar bodies which originate starch.

A $\mathbf{M}^{\prime}$ Y̌LOID, a colloid substance having nearly the properties of boiled starch which is found in many sea-weeds and in the seeds of the bean, the almond, etc.

ĂMY̌LǑLY̌T'ǏC, pertaining to the transformation of starch into other substances, as amylolytic diastase.

ÁM'Y̌LǓM, starch.

AMYLUM BODIES, see PyreToIDS.

AMYLUM STAR, see STARCHSTAR.

ÁN'ǍBİX (pl. Ănăb'içēs), a stem like that of many ferns, etc., which continually dies below and grows above. (Rare.)

ANĂBǑL'ǏC, applicd by Geddes to the series of ascending metabolic changes in protoplasm by which food is assimilated. Compare Katabolic. See Assimillation.

ĂNĂCĂN'THOǓS, without spines. ĂNĂCRǑG'Y̌NOǓS, applied in Jungermanuiex by Leitgeb to forms in which the archegonia do not arise upon or near the apex of the shoot, which therefore usually continues to grow after their formation. Com. pare Acrogryous.

ĂNĀËR $\bar{O}^{\prime} \mathbf{B I} \mathbf{A}$ (sing. Anaërobium), organismus unable to live or thrive in the presence of free oxygen. Applied to certain bactelia. Compare AEromia.

ĂNĀËRŏB'ĬC, see ANA ËROBIOTIC. ĂNĀËRŏBĪǒT'ǏC, being uuable to live in contact with air or free oxygen, as some bacteria, or capable of living in an atmosphere destitute of oxygen: anıёrobious; anaërobic.

ÀNĀËRŎB'ǏOǓs, see AXAËroBIOTIC.

ĂNĀË'RǑPHỸTE, a plant which does not need a direct supply of air.

ĂN'ĂLŏGUE, an organ or body resembling or having the function of another with which it is compared.

ĂNĂL'ŏĞY , resemblance in certain respects, as in general appearance or function. Applied to organs or to classes of plants. Compare AfFixity, Honologr, and MorpHologr.

ĂNĂL'Y̌SIS, the systematic examination of a plant preliminary to determining its position in the classification. Compare DETERMINATIOX.

ĂNĂMÔRPH'ǏSM, see ANAMURPHOSIS. 
ĂN ĂMôR'PHǑsǏs, (1) a gradual change of form (generally ascending) tracel in a group of plants the members of which have sncceeded each other in point of geological time; (2) a similar gradation of form between the members of a group now existing; (3) a remarkable or profound alteration of form resulting immediately from a change in the conditions of growth.

ĂNĂN'DROǓs, without stameus. ÁNĂN'THẼROǓS, without anthers.

ĂNĂN'THERŬM (obs.), see STAMINODIUM.

ĂNĂN'THOǓS, without Howers.

ĂN'ĂPHAȘES. Strasburger's term for the phenomena of karyokinesis following the metaphases (which see) up to the formation of the resting daughter nuclei.

ĂN'ĂPLĂST, see LEUCOPLAST.

ĂNĂS'TŎMŌSE, to communicate or unite with one inother, as the veius of leaves.

ĂNĂSTǑMŌ'SİS (pl. Ănăstomō'sēs), the inosculation or junction of similar parts, often forming a network, as in the veins of leaves.

ĂNĂT'ǑMY̆， VEGETABLE， see VEgETABLE ANATOMY.

ĂNĂT'RǑPOǓs, applied to an ovule or seed which grows so that the funiculus coheres to aud forms a raphe along its whole length. bringing the hilum near the foramen and the chalaza at the apparent apex, as in Liliacex; auatropal.

ĂNÇǏP'ǏTAL, flattened and twoedged, as the stem of Panicum anceps; ancipitous.

ǍÇĬP'İTOǓs, see ANCIPITAL.

ĂNDROCLIN'IUM, see CLINANDIRIUM.
ĂNDRŎDĪE'ÇIOǓs, having perfeet Howers on one set of plants and staminate flowers on another set, but no individuals with pistillate flowers. Compare Andrononcecious and Grnodiccious. See PoLYGAMIOUS.

ÁNDRE్'ÇĬUM, the stamens of a flower taken together.

ĂNDRŎGŏNĬD'ǏU, see ANDRoSPORE.

ĂNDRŎG'Y̌NAL, see ANDROGYNoUs.

ĂNDRŎG'Y̌Nİș, the change from a diœcious to a monocious condition.

ĂNDRŎG' with the staminate and pistillate flowers in the same inflorescence. Said mainly of the heads of certain Compositæ. Compare Polyganous.

ĂNDRǑMǑNE'CIOǓS, having staminate and perfect flowers on the same plant, but no pistillate Howers. Compare ANdiodiceious. See PolraAMOUS.

ĂNDRǑPEัT'ĂLOŬS, said of Howers which have beeome double by the conversion of petals into stamens. (Rare.)

ĂN'DRŎPHŌRE, a column of uniterl filaments, supporting the anthers; stamineal column.

ĂNDRǑPH'ǑRŬM, see ANDIRPHORE.

ĂNDRǑSPŎRĂN'GIŬM, a sporangium containing androspores.

ǍN'DRǑsPōRE, a kiud of asexually produced zoogoniảum or swarm-pore in Edogoniere which develops into small male plants called "dwarf males;" androgonidium.

AN'DROǓs, pertaining to stamens; male. 
ĂNEMǑPH'ǏLOǓs, having the pollen or seeds conveyed by the wind.

ANFRĂCT'ŪōsE, bent hither and thither, as the stamens of the melon.

ĂNĞǏČCÄR'POǓS, having the fruit invested with a calyx, receptacle, or other covering; having spores enclosed by a receptacle of some kind; angiosporons. Especially, having a closed instead of open apothecium in lichens. Compare GYMNOCARPOUS.

ANG'ĞǑSPẼRM'OǓS, having seeds produced in a closed ovary.

ĂNGIOOS'PŏROǓs, having spores or asci produced in a closed receptacle, angiocarpous.

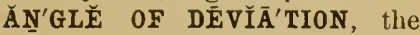
angle which a leaf, branch, or root makes with the axis on which it is borne-on the upper side in branches and leaves, on the lower side in root.

ĂİGLE OF DIVẼR'GENCE, the angle measured by the part of a cycle between succeeding organs in the same spiral or whorl; divergence.

AN'GULAR, having angles or ridges prismatic. In Pomology, having one side developed more than the other, as in the Newtown Pippin apple. Compare OBLIQUE.

ĂN'GŪLAR DǏVẼR'GENÇE, see ANGLE of DIVERGENCE.

ĂN'GŪLĀTE, see ANGLLAR.

ĂNGŪLǑDĚN'TĀTE, having angular teeth.

ĂNGUัS'TĀTE, narıow.

ANGUัS'TIF Ō'LĪĀTE, having narrow leaves; angustifolious.

ANGUัSTIFŌ'LIOUUS, see ANGUSTIFOLIATE.

ANGUัSTǏSE'T'TĀTE, having a narrow septum or partition, as the pod of shepherd's-purse.

ǍNISǑG'Y̌NOǓS, having fewer carpels than sepals.

ĂNİSOัM'EROǓS, not having the same number of floral orgaus in the different whorls. Compare IsOMEROUs and UNSYMMETRICAL.

ĂNİSŏPĚT'ĂLOǓS, having petals of unequal size. (Rare.)

ǍN ĪSǑPHY̌L'LOǓS, unequa]leaved, as when the two leaves of a pair are of unequal size.

ĂNİSŏP'TEROǓS, having wings of unequal size.

ĂNĪSǑSTĂM'ĚNOǓS, see ANISOSTEMONOUS.

ÂNĪsŏsTĚM'ŏNOǓs, having the stamens differing in number from the petals (or parts of the periauth when the sepals are petaloid). Compare IsostenoxOUs.

ĂN ĪsŏTRŏP'Ǐc, having the different parts or organs endowed with diflerent kinds of irritability, or in differen! degrees, as stems which seek the light and roots which shun it.

ĂNNOัT'ǏNŬS, the riug upon a stem which marks the close of a season's growth. It consists of the scars left by the fallen scales of the bud from which the next year's growth proceeded.

ĂNNOัT'ǏNOǓs, having distinct yearly growths.

ĂN'NŪAL, a plant which usually lives but one year or season.

ANNUAL RING, the ring or cylinder of wood produced by exogeuous plants during the year. In some cases the annual ring consists of more than one ring of growth, hence the term "growth-ring" is now often used. 
$\triangle N^{\prime} N U L A R$, in the form of a circle or zone.

ANNULAR DUCTS, SE VESSELS.

ANNULAR VĚSSELS, vessels marked with thickenings in the form of a ring.

ĂN'NŪLÄTE, marked with rings or circular transverse lines; annuluted.

ĂN'NǓLĀTED, see ANNULATE.

ĂNNŬLA'TION, a ring ol belt.

ÁN'NŪLŌSE, furnished with or composed of rings.

ĂN'NŪLǓS (pl. Ăn'nūlī), ayy body in the form of a ring; the ring or band of thick-walled cells in the sporaugium of most ferus which by contraction bursts the sporangium and liberates the spores; the ring of cells upou the inner side of the base of the peristome at the orifice of the theca in many species of mosses which is thrown oft to detach the operculum; the ring on the stem of mushrooms; the abortive foliar sheath at the base of the spike in Equisetum.

ĂN'ŎDĂL, see ANoDIC.

ÁNŎD'ǏC, applied to the edge of a leaf which a leaf-spiral leaves in its upward course. In a right-handed spiral it would be the right edge of the leaf, and vice versa. Compare CATHODIC.

ANǑM'ĂLOǓs, unusual in appearance; contraly to rule; abuornal; irregular.

ĂNǑM'ĂLY̌, any deviation from the essential or usual character.

$\breve{A} N^{\prime} S \bar{U} L \bar{A} T E$, coiled at the apex and the whole coil beut over so as to make a loop projecting above the coil, as the growing extremity of the vine of the musk-melon.

ĂN'TECHĀMBER, the upper (outer) angle or space between the guard-cells of a stoma. Compare Vestibule.

ĂNTĚN'N花 (sing. Åntěn'nà), two slender horn-like prolongations of the rostellum in the genus Catasetum in orchids which, upon being touched by an insect or other object, cause the liberation of the retiuaculum at their base and the ejection of the pollinium.

ĂNTEPǑŠI'TION, see SUPERPOSITIOX.

ÁNTE' RǏO-POSTE'RIOR PLANE, see Mledian Plaxe.

ĂNTE' $\bar{E}^{\prime} \mathbf{I}$ ŏR, the sicle of a tlower, leaf, or other orgau away from the main stem or axis; inferior; exterior; in front. Compare Dorsal.

ÁNTHÉ $\mathbf{L A}$, a paniculate cyme with the lateral axes overtopping the central, as in mauy species of Juncus and Luzula.

ÁN'THEMY̌, a flower-cluster of any kind. (Obs.)

ÁN'THER, the pollen-bearing part of a stamen.

ĂN'THERĬD'ǏŬM (pl. Ăntherid'ia), the male orgau in the higher cryptogims within which antlierozoids are produced.

ANTHERǏF'EROǓS, anther-bearing.

AN'THER-LOBES, the cells or sacs of an anther, usually two in number, containing the pollen.

ÁN'THEROID, anther-like.

ĂNTHERǑSPŎRĂN'G' ĞŬ Ăntherǒsporrăn'giả), see MIcRo. SPORANGIUM.

AN'THERŏZOID, one of the motile fertilizing bodies produced in an antheridium; spermatozoid. 
ĂNTHE'SǏs, the time or act of flowering; florescence.

ANTHǑCÄR'POǓs FRUIT, generally used for Collective fruit, but more properly for Accessory fruit.

AัNTHŎCLINN IUUM, see CLINAN'THICM,

ĂNTHŌ'DǏ UัM, the capitulun or head of Howers in Compositie (popularly ealled a Hower). Compare Clinantmum.

Ă ${ }^{\prime}$ THOID, resembling a flower.

ĂN THŏLİTE, a fossil tlower.

ĂNTHǑL'Y̌SIS, a retrograde metamorphosis of a flower by which normally united or contiguous pirts are separated; solution of a flower. The parts of the altered flower may or may not be changed in eliaraeter.

ĂN'THŎPHŌRE, a stalk or internode sometimes leveloped between the calyx and corolla, as in Silene.

ANTHǑTĂX'Ǐs, the arrangement of Howers in au intlorescence; anthotaxy.

Ă'THŌTĂXÝ, see ANTHoTAXIS.

ĂNTĬCLI'NĂL, sajd of cell-walls or any lines when perpendicular to the onter surface. Compare Periclinal.

ĂNTI'COǓS, facing anteriorly.

ÃNTÍD RŏMĂL, twisted or cuiled in an opposite direction to that with which it is compared, as when the leaf-spiral of a branch turns in the opposite direction from that of the stem; anticlromous. Compare Homodroyous and Heterod. RoMOUS.

ĂNTĬD'RŏMOŬS, see ANTIDRoMAL.

ĂNTÍD'RŏMY̌, having the course of a spiral reversed from the usual direction.

ĂNTǏMY̌cŏT'ÍC, see FungicIDAL.

ĂNTÍPATHĚT'ǏC, said of plants which do not unite readily when grafted.

ĂNTİPEDUNN'CŨLAR, situated opposite tu a peduncle.

ĂNTǏPĚT'ÁLOǓS, situated opposite to a petal, i.e., directly between the petal and the axis; autepetalous.

ĂNTĬP'ŎDĂL CELLS, a group of foul cells at the lower end of the embryo-sac, one of which, destitute of a wall, is the lower polar nucleus. Compare EgGAPPARATCS.

ĂNTǏsĚP'TĬC, preventing putrefisction.

ĂNTǏT'RŎPAL, see ANTITRoPOLS.

ĂNTǏT'RŏPoǓs, having the ladicle of the embryo direeted away from the lilum, as in orthotropous seeds.

ĂNTǏZȲMǑT'ǏC, preventing or checking fermentation.

ĂNTRôRsE', directed upward or forward. Compare ANTICots.

ĂPĚRǏSPẼR'MĬC, see ExALBUMINOUS.

ĂPĔT'ĂLOǓS, destitute of corolla.

$\bar{A}^{\prime} \operatorname{PEX}$ (pl. $\overline{\mathbf{A}}^{\prime}$ pěxes or $\left.\mathrm{A}^{\prime} \mathrm{p}^{\prime} \mathrm{cēs}\right)$, the extremity opposite the point of attichment.

ĂPHELLัOTRǑP'ǏC, turning from the sun; negatively heliotropic.

ĂPHY̌L'LOǓS, without leaves.

ÁPHY̌L'LY, the abnormal suppression of leaves.

ĂP'ICAL CELL, the generating cell of a growing point. 
ĂP'ICAL CONE, see PUNCTUM VEGETATIONIS.

ĂPIC'ŨLĀTE, terminated by an abrupt short acute point.

ĂPIC'ÚLATED, see APICULATE.

ĂPǏC'ŪLŬS (pl. Ápǐc'ūlī), a small acute point.

APLAN OSPORE, applied by Wille to non-motile reproductive cells formed by rejuvenescence in Conjugatex and some other green algæ.

ÁPLĂS'TĬC, not capable of being organized, or converted into auimal or vegetable tissue.

ÁPŏcÄR'POǓs, having the carpels separate or easily separable, as in Ranunculus; dialy. carpous.

APǑG'ĂMY̆, habitual non-sexual reproduction, especially vegetative reproduction where sexual reproduction usually occurs, as in the budding of a prothallus iu ferus. Compare Partienogenesis and VegeTIVE APUGAMY.

ÅPóGĒTTRǑP'ÍC, growing away from the earth, as ordiuary stems.

ÅÖPĔT'ĂLOŬS, having the pet. als of the corolla uuattached to each other; eleutheropetal. ous; polypetalous.

АРО̆PHY̌L'LOŬS, sometimes used for aposepalous, especially iu flowers having but one perianth whorl.

А. ysis.

גРŎPH'Y̌s̆̌s, au enlargement of the seta below the theca in certaiu mosses; a thickening on the scales of the cones of certain pines; any irregular swelling.

ÅǑSĚP'ÁLOǓs, having the leaves of the calyx unattached to each other.
ÅǑS'TĂSĬS, a term applied by Engelmann to the separation of organs by an unusual extension of the internodes; solution. Compare Dialysis.

APÓS'TRŎPHE, the collection of the protoplasm and chlorophyll grains aloug the sicle walls of a cell instead of the outer surface-often caused by cold or excess or deficiency of light. When caused by deficiency of light, as at night, it is called "negative apostrophe"; when caused by too bright a light, "positive apostrophe." Compare EPISTRoPHe and SisTROPHE.

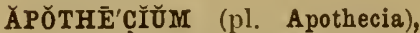
the ascocarp in lichens. See Discocarp, Shield, and PeriTHECIUN.

ĂPPĚND'AGE, any superadded or subordinate part; as hairs, prickles, leaves, etc., upon a stem.

ÅPENDĬC'ŪLĀTE, having an unusual appendage or appeudages, as a winged petiole, or spurred corolla.

ĂP'PLĂNĀTE, flattened out or horizontally expanded. Compare Explanate and CosPLANATE.

ĂP'PLĬCĀTǏVE, see CONDUPLI. CATE.

ĂP'Pōs̄ÍTE, close together; side by side.

ĂPPRĚSSED', lying close, as leaves to a stem; adpressed.

ÁPPRŎX'ǏMĀTE, close together but not united. Compare REMOTE.

ÁP'TEROǓS, having no dilated appendage or wing. Compare Alate.

ÅUĂT'ǏC, growing in water or wet soil. See Palustrine. 
A'QUEOǓS, nearly colorless. See HYALINE.

ĂRĂCH'NOID, covered with loug and loosely entangled hairs, the hairs fewer aud longer than in 'Tomentose; colvebby.

ĂR'A'NĔUS, see ARACHNoID.

ÄR'BǑR, sce TREE.

ÄRBO'́REAL, pertaining to trees or forests.

ÄRBŌ'REOǓs, having the vature of a tree; pertaining to trees.

ÄRBǑRĽS'ÇENT, tree-like in size or for'm.

ÄRBǑRE'TǓM, a botanical tree garden.

ÄR'BǓSÇLE, a low shrub having the form of a tree.

ÄRÇÉS'THǏDA (obs.), see GALBULUS.

AR€HĒB̃̄ō'SĬs, the origin of life. see Spoxtaneous GeneliaTION.

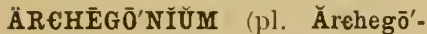
nià), the female organ in the higher cryptogams. Compare Oogoxium. See ANTuERIDIUM.

ÄR€HĒSPŌ'RĬUัM, the cell, group, or layer of cells from which the spore-mother-cells, and tapetum if auy, are derived in the higher cryptogams and flowering plants.

ÄREH'ET $\bar{Y} P E$, the original type or conclition.

ÄREH'ÍCARP, the beginuing of a fruclification; a cell or group of cells fertilized by a sexual act, as an ascogonium or carpogonium.

ÄR'CŪĀTE, curved like a bow.

$\overline{\mathbf{A}}^{\prime} \mathbf{R} \overline{\mathbf{E}} \dot{\mathbf{A}}$, a rather large space bounded by crateks, lines, veins, or part differing in color or texture. Compare Areola.

ARENĀ'ÇEOǓs, growing in sandy places; arenareous; arenose; sabuline; sabulose.

ÅĚNA'RǏOǓs, see ARENA. CEUUS.

ÁR'ENŌSE, sec ARENACEOU's.

ÁR $\overline{\mathbf{E}}^{\prime}$ ŎLA (pl. Arē'ólæ), diminutive of area, any small space sur. rounded by a part differing in structure or color, as the spaces bounded by the veins in reticulate leaves, by the cracks in the surface of the thallus of cer. tain lichens, or by the cell. walls in the leaves of mosses; areolation; areole.

ARE' ÓL $\mathbf{A} T \mathbf{E}$, divided into areolæ. ÁR̆̌ŎLA'TION, (1) see AREOLA; (2) the form and arrangement of the areola in mosses, etc.

$\bar{A}^{\prime} \mathbf{R E} \bar{L} L E$, see AKEOLA.

ÄRĞẼNTEǓS, white with a tinge of gray; silvery.

ÄRGILLA'CEOǓS, growing in a clayey soil; argillose.

ÄR GÍLLŌSE, see ArGILlaceous.

ÁRHI'ZAL, without roots.

ÁR'ǏL, a false coat which sometimes surrounds the seed, growing from the funiculus, hilum, or placenta, as the mace of nutmeg. Compare stroPHIOLE.

ÅÍL'LÁ, see ARIL.

ĂR'ǏLLĀTE, having an aril.

ĂR'ǏLLĀTED, see ARILlAte.

ÁR'ǏLLōDE, a false covering to a seed resembling an aril.

ARILL'LŬS, see ARIL.

ÁRÍs'TÁ, see AwN.

ȦRIS'TĀTE, having an awn.

ĂRİ'TŪLĀTE, having a small a $n$.

ÄRM, in horticulture, a large branch of a vine trained horizontally.

ÄRMED, having thorus, spines, or prickles. 
ÄRMǏL'LA, an annulus in the for'm of a plaited frill sus. pended from the top of the stipe below the eap in certain mushrooms.

AR $\overline{0}^{\prime} \mathbf{M A}$, a pleasant cliaracteristic odor.

Ån̄MĂT'ǏC, possessing aroma, especially if spicy.

ARRĚCT', directed upward from an inclined base, as the pods of milkweed. (Asclepias.)

AR'RŌW-HĚAD'ED, see SAGITTATE.

AR'RōW-SHĀPED, see SAGITTATE.

ÄR'THŎNOID, resembling the apothecium of the genus Arthonia in lichens.

ÄR'THRŌSPŌRE, used mainly in bacteria for a spore formed by segmentation, as opposed to Endospore.

ÅTHRŌSTẼRIG'MÁ (pl. Ärthrōsterig'măta), a jointed sterigma in many lichens, composed of a row of cells from each of which spores are abstricted.

ARTǏC'ŨLĀTE, jointed; articulated.

ARTǏC'ŨLĀTED, see AR'TICU. LATE.

ÄRTÍCÛLL'ÁTION, (1) a node, joint, septum, or separable place; (2) one of the segments so marked off or separated.

ÄRTǏC'ŨLŬS, formerly used botlı for uode and internode.

ÄRTÍFI'CIĂL SYSTEM, a system of classification based on one or a few features only, and not intended to sliow true relationship, as that of Linnceus.

ARŬNDǏNĀ'CEOŬs, reel-like.

ASÇĚND'ENT', see AscENDING.

ASÇĚND'ǏNG, rising obliquely, or curving upwards from near the base, as the stems of
Stellaria or the branches of Norway spruce; adscendent; ascendent: assurgent; adsurgent. Said of ovules which are attached to the middle portion of the placenta or sides of the ovary and are directed upward. Also, directed upward in any manner in contrast to descending, as the ascending axis.

ĂSÇĔND'ǏNG $\check{A} X \check{I}$, the stem.

ĂSCĚND'ǏNG MĚTĂMÔR'PHO. Sİs, see Profiressive MEtaMORPHOSIS.

ĂS'ÇI, pl., see Ascus.

ĂSČID'ǏÁ, pl., see Ascidiur.

ĂSC̣ID'ǏFôRM, ascidium-shaped.

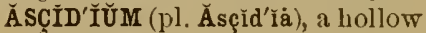
pitcher-shaped leaf, like that of Sarraceni:.

ĂSÇIF'EROǓS, see AscopHorous. ĂSÇİG'ẸROǓs, see AsCOGENoUs.

Ás'CōcÄRP, the sporocarp of Ascomycetes. See АротныCivi, Perithecium, and Cleistocarp.

ĂSCÓG'ENOǓS, producing asci; ascigerous.

Ăs'CōGōNE, see Ascugonium.

ÁsCōGō'NǏUM, the carpogonium, or female orgun in Ascomycetes before fertilization.

Ás'CŌPHŌRE, the ascus-bearing layer of hyphæ lining an ascocarp.

ĂSCǑPH'0̄ROǓS, ascus-benring; asciferous. Compare AscogENous.

ÁS'CōsPŌRE, a spore produced in an ascus. Often inappropriately called sporidium or sporule.

Ás'cǓs (pl. Ás'çi), one of the characteristic spore-cases of Ascomycetes borne in an ascocarp. It consists of an eularged terminal cell containing free 
spores, most frequeutly eight in number.

Ás'CŬS-ĂPPĂRĀTŬS, the asci, together with the ascogenous cells. See ENVELOPE-APPARAtus.

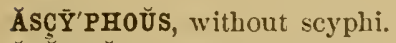

Áš̆P'TÍc, not liable to putrefaction.

Aš̌X ŪAL, withont sex; destitute of stamens and pistils in Howering plauts, or other sexual organs in cryptogams.

ÁSĚXŪAL ĠENERA'TION, the second stage or generation in plauts having an altermation of generations. It produces spores asexually, but is itself the result of fertilization. In ferns the prothallus is the sexual, and the leaf-beariug plant the asexual, geveration. See SPorogonium.

Ás'PERĀTE, see ScABRous.

Ás PẼRǴ̆ĹL'L IFôRM, resembling au aspergillus (a round brush used to sprinkle holy water in Roman Catholic churches), as the stigmas of some grasses. Compare II scariforu.

ÁSPẼRǏFō'LİĀTE, having leaves rough to the touch.

ASPẼRIFF̄'LǏOǓS, see AsPERFOLIATE.

ĂSPẼR'MOǓS, without seeds.

ÁS'PẼROǓs, see ScABRous.

ÁSSIMIL $\bar{A}^{\prime} T I O N$, the conversion of foreign material into the substance of the plant; constructive metabolism.

ĂSSÛR'GENT, see AsCENDING.

ĂS'TER, see MIoTHER-STAR, DTASTER, AMPHIASTER, and CYTASTER.

Ás'TERŌID, having flowers like the Aster. Compare Actisi. FORM.

Ás'TICHOǓS, not in rows.
Ăs'TōMoǓs, without aperture, as mosses which have not in de. ciduous operculum.

ǍSY̌MMĚT'RICCAL, not symmetrical, which see.

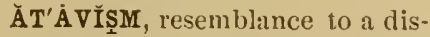
tant ancestor; remote heredity.

$\bar{A}^{\prime}$ TER (in composition, ătro-), pure black, as distinguished from Niger.

ĂTHĂL'LĪNE, without thallus.

ÁT'RōPĂL, see ORTIOTTOPOL's.

AT'RŌPHY̆, a dwarfed or stuuted couditiou of an organ as compared with others, or with the usual state. Especially applied to parts which seem wasted away from lack of nourishment or other cause. Compare Abortion and DEGENERATION.

ÁT'RŌPOǓs, sce ORTHOTROPOL's. ÁTRŌPÛRPU'́REǓS, dark purple. ĂTTĚN'ত̄ $\bar{A} T E$, tapering gradually to a point or narrow extremity.

ATTĔN'ŪĀTED, see ATTENUATE. A.UGMĔTTA'TION, increase beyond the normal number, especially the production of additional Horal whorls.

A U'LŌPHȲTE, a plant which lives within another for shelter ouly, not as a parasite, as some Protococcicex.

ẠURĂNTǏÁ'ÇEOǓS, orange-colored. Darker than Aureus.

AU'REǓS, yellow, with a slight admixture of red; golden.

A U'RICLE, any ear-lilie appendage, as the lobes at the base of the leaves in sorrel.

A RICLED, see AURICULATE.

ÅURǏC'ULA் (pl. Ạuríc'ūlǣ), see AURICLE.

AุURÍC'ŪLĀTE, having auricles, or ear-like lobes or appendages. 
AUURIC'ŨLĀTED, see AURICULATE.

ÂU'RĬFÔRM, having the form of the human ear.

A.USTËRE', astriugent or harsh to the taste.

AUTŌCÄR'YOŬS, said of ovaries which are not adherent to the calyx; superior.

AUTE'ÇIOǓS, said of a parasitic fungus which inhabits the same host-plant through all its stages of growth. Compare Heterecious. Applied in mosses when the male and female "flowers" are in separate involucres upon the sime plant.

ÅUTǑG ĂMoŬs, self-fertilizing.

ÅUTŎG ĂMY̌, close-fertilization the fertilization of a flower by its own pollen. Compare $\mathrm{AL}$ LOGAMY.

ÅUTŌĞĚN'ĚSǏs, see SPONTANE. ous Genera'ion.

AUTTOG'ENOǓS, self-originating. Applied to diseases which have their origin or cause within the effected organism. Compare INFECTION, ESOTERIC, and EXOTERIC.

ÅTOKG'ENŬS Or MONǑG'ENŬS, terms proposed in place of Monotypic, to indicate that a genus contains but a siugle species.

ÅUTON'ŌMOǓS, complete in itself. Applied to forms which continuilly and direetly reproduce themselves, and are not mere stages in the life of a plant.

ÅUTŌPHY̌LLŎG'ENY̌, the growth of oue leaf upon another.

AUU'TŌPLĂST, see CHIoROPIXYL. BODY.

AUTŌTĚM'NOŬS, capable of spontaneous division, as ordinary growing cells.
AUX'ŌSPŌRE, a large renewalcell in Diatomacex, formed either by rejuvenescence, or developed from a zygospore produced by conjugation.

AUXX̄TŌNIC MOVEMENTS, those made by growing organs, as the twining of stems. Compare Allassutonic MoveMENTS.

ĂVẼRSE', turned or facing away from the central axis or other object. Compare Adverse.

AWL'-SHĀPED, see SUBULATE.

AWN, a bristle-shaped appendage, like those on the ginmes of many grasses; arista; beard.

AWNED, having an awn or beard; aristate.

ĂX'FôRM, see DoLABRIForm.

$\breve{A} X^{\prime} \breve{I} A L$, pertaining to an axis; extending in the direction of an axis; forming an axis. Compare Axile.

ĂX̌F EROŬS, having an axis; producing stẹns but no leaves.

ĂX'ÍL, the upper angle between leaf aud stem; auy angle.

ĂX ÍLE, occupying or belonging to the axis, as in axile placenta.

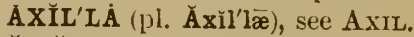

AXX'ÍLLAR, see AXILLARY.

ÁX'ÍLLĀRY̌, pertaining to or occupying an axil.

ĂX'Ǐs, the central line of any body; an organ around which others are attached, especially a main stem or root.

AXIS, ASCENDING, see ASCENDING AXIs.

AXIS, DESCENDING, see DERCENiDING AXIS.

AXIS OF INFLORĔS'CENCE, the part of the stem or brauch aloug which flowers are borne. See Receptacle and Rachrs.

AX'-SHĀPED, see DolabriFORM. 
ĂZȲG'0̄SPŌRE, a spore in certain algæe and fungi resembling a zygospore, but produced asexually.

AZ Y̌GOǓs, without a fellow or corresponding part, as a leatlet which does not have another leatlet on the opposite side of the rachis.

BĂC'CÁ, see BERrT.

BĂC'CĀTE, berry-like; pulpy.

BĂC'CĀTED, covered with berries, or bodies resembling berries.

BĂCÇǏF'EROǓS, producing berries.

BĂC'ḈF̂́RH, see BACCATE.

BÁCÍLLȦR, rod-or club-shaped, like a bacillns; bacilliform.

BĂCK, see DoRsum.

BĂCTÉ'RIOIDS, protoplasmic bodies endowed with Brown ian movement, aud resembling bacteria.

BALD, destitute of the usual cov. ering, as of hair, foliage, etc.; destitute of beards or awns.

BALŬS'TRÁ, sometimes applied to fruits like the pomegranate.

BĂND, (1) a space between two ridges or the fruit of $\mathrm{Lmbel}$ liferz; $(2)$ a broad stripe, es pecially if transverse.

BĂN'NER, see VExILLCM.

BÄRB, a sliary retlexed point on an awl or other process; a hair or other process having such reflexed points, or with a retlexed tip.

BÄR'BĀTE, see BEARDED.

BÄR'BĀTED, see BEARDED.

$B A ̈ R B E$, see BARB.

BÄR'BELLĀTE (diminutive of Barbate), having minute barbs; harbellulate.
BÄRBĔL'LŪLĀTE, see BARBELLATE.

BÄR BŪLE, a small barh.

BÄR, the covering of the stem and roots of exogens, separated from the wood by the cambium.

BÄRRED, crossed by parallel horizontal bands or liues.

BĂR'REN, unproductive; unfruitful; sterie, - ssicl of a plant or organ. The term "barren" is seldom applierl except to a plant as a whole, and even then the term "sterile" is more often used.

$B \bar{A}^{\prime} S A L$, pertaining to the base.

$B \bar{A} S E$, the part of an organ by which it is attached to its sup. port.

BĀSĬDĪōGENĚT'ǏC, borne on a basidium.

BĀSǏD' ǏŌPHŌRE, a sporophore bearing a basidium.

BĀSIJD'ǏŌSPŌRE, a spore borne on a basidium, as those of mushrooms.

BĀSĬD'ǏŬM (pl. Bāsĩd'ìa), one of the branched cells on the spore-bearing surface of mushrooms, etc., which bear the spores. ('ompare STERIGMA.

BĀS'ǏFIXED, attached by its base, as an inuate anther.

BĀSǏF' ÜGĂL, (1) proceeding away from the base; upward; acropetal; centrifugal (centripetal when applied to the order of inflorescence); (2) derived from the base or sitnated at the base, as basifugal growth in the leaves of certain grasses.

BĂSÍGY̌N'ÍUM, see GrropHoRE.

BĂS'ǏLAR, relating to or situated at the base.

$\mathbf{B A} \mathbf{A} I \mathbf{N}$, the depression at the 
apex of an apple. Compare CAvity and ExE.

BĀSǏP'ETAL, proceeding or produced in succession toward the base; downward; centrifugal (when applied to the order of inflorescence only). C'ompare Acropetal.

BÄSǏscŏP'ǏC, on the side toward the base; facing the base.

BȦsS, see BAsT.

BĂST, the liber or iuner bark; particularly the long, tapering, thick-walled phloèm-cells characteristic of such bark.

BĂS'TÄRD, spurious; resembling something else. Used improp. erly for Hybrid.

BĂST-ÇĚLLS, thick-walled elongated spindle-shaped cells in the phloëm portion of tibrovascular bundles. They grive strength and flexibility to the tissues; bast-fibres.

BĂST-FİBRES, see BAST-CELLS.

BAst-ShêATH, see PhLoemSHEATH.

BAST, SOFT, see SOFT BAST.

BAst-TISSUE, see Phloem

BAST-VĔS'SEL, see SIEVE-TUBE.

BËAK, a process like the beak of a bird terminating the fruit of many leguminous and other planis; rostrum.

BE $\overline{E K E D}$, ending in a prolonged narrow rigid tip like a beak; rostrate.

BËARD, the awus of grasses. siugly or collectively; a tuft of hairs, especially if stiff and long: sometimes applied improperly to the lower lip of labiate corollas.

BĒARD'ED, having a bearl; beset with hiirs, especially if stiff and long.

BEARD'LETED, having minute beards or awns.
BĚLL'-SHĀPED, see CAMPANULATE.

BĔL'LY̌ǏNG, swelling out on one side, as the tube of the corolla iu many Labiater.

BĚR'RİED, see BACCATED.

BĔR'RY̆, an indehiscent fruit pulpy or fleshy throughout, as the grape, currant, and tomato.

BĪĂCU' $\mathbf{M}$ ǏNĀTE, two-pointed.

BĬĂN'GŨLĀTE, luaving two angles or corvers.

BÎARTĨC'ŪLĀTED, having two joints.

BİẠURǏC'ŪLĀTE, two-eared.

BİBRĂC'TEĀTE, with two bracts.

BĪBRĂC'TEŌLĀTE, having two bractlets.

BİCĂL'CĂRĀTE, having two spulus.

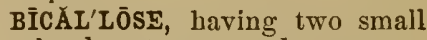
hard spots or protuberances.

BĪCĂP'SŪLAR, haviıg two capsules. Sometimes applied to capsules which are divided before deliscence iuto two parts.

BĪCÄR'PELIÄRY̆, see DICARPELLARY.

BĪCÁR' IN ĀTE, two-keeled, as the palet of grasses.

BĪÇĚPH'ĂLOǓs, having two heads.

BİČİ' ǏTĂL, divided into two parts.

BİCIP'ǏTOǓs, see BICIPITAL.

BÍCOLLĂT'ERAL BUNDLE, a fibro-vascular bundle in which a strand of xylem lies between two stranils of plıloem.

BI'́COLǑR, of two colors.

BI'COLÖRED, see BICOLOR.

BĪCŏN'JŪGĀTE, see BIGEMINATE.

BĪCôR'NÛTE, with two horn-like processes.

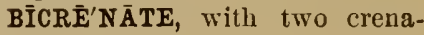


tures or rounded teetl, Compare Doubly-CRENATE.

BİCRƯ'RAL, having two legs or nalrow elongutions, as the lip of the "man-orchis."

BĪCǓS'PİD, having two sharp stiff points or cusps; bicuspiclate.

BĪCǓS'PĪDĀTE, see BICUSPID.

BĪDĚN'TÁTE, having two teeth. Compare Doubly-dentate.

BĪDÍG'ǏTĀTE, having two fiugerlike divisions.

BĪD'ŪoǓs, lasting two days only. BĪEN'NǏAL (adj.), living two years, or requiring two seasons to come to maturity.

BĪĚN'NǏAL, (n.), a plant which usually mitures its fruit the second year and then dies.

BIFA'CIĂL, applied to leaves which have a distinct upper and lower surface differing in texture. Compare CEnTric.

BĪFA'RĪOǓs, pointing in two directions; two-ranked; distichous.

BI'FËR, a plant which ripens fruit twice a year.

BǏF'EROǓs, fruiting twice a year.

BI'FÍD, divided about to the middle in two parts; two-cleft.

BǏF'ǏDĀTE, see BIFID.

BIFǏS'TÛLAR, containing two tubular openings.

BİFLō'RĀTE, see BIFLorous.

BĪFLŌ'ROǓs, two-flowered.

BIF́̄LĪATE, having two leaves or leaflets.

BIF $\bar{O}^{\prime} \mathbf{L} \breve{I} \mathbf{L} \bar{A} T E$, having two leaflets.

BIFF̆LLIC'ŨLAR, with a double follicle.

BIF $\bar{O}^{\prime} \mathbf{R} \bar{A} T E$, having two perforations, as the anthers of Rhododendron.

BIF'ŌRINE, a peculial cell con- taining raphides found in arums and certain other plants -so called because when placed in water they become turgid and discharge their contents, often from both ends.

BǏF'ŌROǓs, see BIFORATE.

BI'FRŏNS, haviug two faces or aspects; growiug on both surfaces of a leaf (amphigenous).

BĪFUR'CĀTE, forked; divided into two branches.

BIFUR CĀTED, see BIFURCATE. BIFURCA'TION, division into two branches.

BİFÛR'COǓs, see BIFURCATE.

BÏĞ̌M'ǏNA ĀTE, twice paired, as a decompound leaf with two pairs of lentlets, i.e., having a forked petiole with a pair of leaflets at the end of each division; biconjugate.

BI'ǴENĚR, see GENUs-HrBRID. BĪGLĂND'ŪLAR, luaving two glands or gland-like bodies.

BI JU' $\bar{U}^{\prime} \mathbf{G} \bar{A} T E$, having two pairs, as a leaf with two pairs of leatlets.

BİJU'GOǓs, see BIJUGATE

BĪLA'BI B̆̄TE, see LABIATE.

BILĂM'ĚLLÄR, see BILAMELLATE.

BĪLĂM'ELLĀTE, of two plates or lamellæ.

BĪLĂM'ELLĀTED, see BILAMEL. LATE.

BİLĂT'ERAL, two-sided.

BĪLO'BĀTE, two-lobed.

BĪLŌ'BĀTED, see BiLoBATE.

BI'LŌBED, see BILOBATE.

BĪLǑC'ŪLÄR, two-celled-applied to ovaries, anthers, etc.

BİM ĂC'ŪLĀTE, having two spots. BĪMĂC'ÜLĀTED, see BuACULATE.

BI'NĂRY̆, in twos; double.

BI'NATTE, in twos or pairs; conjugate--said of two bodies of 
the same nature springing from the same point. In speaking of pinnate leaves the term conjugate is generally used.

BĪNE, a twining or climbing stem. Rare except in composition, as wood-bine.

BĪNẼRV' $\overline{\mathbf{A}} \mathbf{T E}$, haviug two nerves or veins, or two which are especially prominent.

BĪNó'DĂL, containing two nodes only.

BINŌ'MǏAL, of two names, as the generic and specific names which compose a " botanical name."

BI'NOǓs, see BINATE.

BINNŪ'CLËR, see BINUCLEATE.

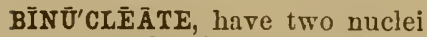
or central points; binuclear.

BIN $\bar{U}^{\prime} C L \bar{E} \bar{L} \bar{A} T E$, with two nucleoli.

BĪOC Ç'ELLĀTE, with two eye-like spots.

BĨóGÉN'ESǏs, (1) the origin of life; (2) the production of living beings from other living beings in any manuer-the converse of spontaneous generation (abiogenesis).

BĪǑG'ENGUัS, growing on living plants, either parasitic or not.

BĪÓG'ENY̌, the genesis or evolution of living forms, or the science which treats of it, includ. ing Ontogeny and Pliyllogeny.

BĪOL'ŌGYY, zoology and botany.

BĪōIY̌T'ǏC, injurious or destructive to life.

$\mathbf{B} \bar{I}^{\prime}$ OKN, an individual norphologically independent.

BĪŏPH'ÄGOŬS, feeding on living organisms. Applied chiefly to insectivorous plants.

BI'ÖPIĂSM, any living fluid; the same as protoplasm.
BĪPĀL'ĒōLĀTE, with two lodicules; bilodiculate.

BĪPĂL'MĀTE, saìl of leaves which are palmate upon sec. ondary palmate petioles.

BIP'ÁROǓs, benring two objects, as a leaf with two leaflets.

BĪPÄR'TED, see BIPARTITE.

BIPÄR'TĬBLE, divisible into two parts.

BĪPÄR'TǏLE, see BIPAPTIBLE.

BIPÄR'TITE, two-parted; divided iuto two parts to the base or nearly so.

BĪPÄRTÍTION, the act of dividing into two equal parts. Compare Bisection.

BĪPĔC'TǏNĀTE, toothed like a comb on two sides.

BĪPĚL'TĀTE, having two shield. shaped parts.

BÎPĚRĚN'NĬLL, said of a part which lives two years, but reproduces itself indefinitely, as the tubers of the potato. (Rare.)

BĪPĚT'ÄLOǓS, having two petals.

BĪPǏN NĀTE, said of a piunate leaf with secondary petioles, each bearing more than one leaflet, as the honey-locust; doubly pinnate; twice pinnate.

BİǏ̃N'NĀTED, see BIPINNATE.

BĪPINNĂT'ǏFĬD, having the divisions of a pinnatifid leaf pinnatifid; twice pinnately cleft.

BĪPǏNNĂTǏPÄR'TĪTE, laving the divisions of a pinnatipartite leaf pinnatipartite; twice pinnately parted. It differs from Bipinnatifid in having the divisions extend to near the mid. rib.

BĪPINNĂT'ǏSECT, having the divisions of a pinuatisect leaf 
pinnatisect; twice pinuately divided. The divisions extend to the midrib, but the segments are sessile.

BĪPL $\bar{I}^{\prime} C \bar{A} T E$, twice or loubly folded.

BĪPŌ'RŌSE, having two small openings or pores.

BĪPǓNC'TĀTE, having two small spots.

BİRA'DǏĀTE, having two rays.

BĨI'MŌSE, opening by two slits, as most anthers; having two clefts, slits, or narrow openings.

BİSĂC'CÃTE, having two sacs $\mathrm{or}^{\circ}$ pouches.

BİSCU'TĀTE, resembling two round bucklers placed side by side.

BÍšCT', to divide into two equal parts.

BISĚC'TION, the act of cutting or dividing into two equal parts: bipirtition.

BİSĚP'TĀTE, having two partitions or septa.

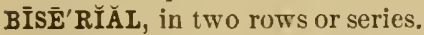

BIISĔR'RĀTE, baving the teeth or serritures serrate; doubly serrate. The latter term is preferable, and Biserrate, though in more common use in this sense, should be applied in analogy with Bidentate to leaves or margins bearing two serritiires.

BİsE TŌSE, having two bristles; bisetous.

Bİs̄' TOǓS, see BisETosE.

BĪSĚX'ŪAL, containing both sexes, as a flower with both stamens aud pistils; hermaphro. dite; monoclinous; synœecious.

BĪSPI'NŌSE, having two spines.

BI'́SPŌRE, a two-spored tetraspore.
BĪSTǏP'ŪLED, having two stipules.

BĪSǓL'CĀTE, having two longitudiual grooves or furrows.

BĪTẼ R'NĀTE, divided into tliree parts, each of which is divided into three.

BǏT'TEN, see ERosE.

BI'VĂLVE (adj.), having two valves, as some capsules; bivalvular.

BI' $\overline{I^{\prime}}$ ĂLVE (n.), a capsule of two valves.

BĪVĂLV'ŪLÄR, see BIVALVE.

BĪVĂS'CŪLÄR, having two ves. sels.

BĪVIT'TĀTE, having two vittæ.

BLĂD'DER, (1) an inflated membranous pericarp; (2) a mem. branous air-sac in some waterplants which enables them to tloat. See AIR-BLADDER.

BLĂD'DERY̌, thin and inflated like a bladder, as the calyx of Silene inflata.

BLĀDE, the expanded portion of a leaf; lamina. The term blade is more commonly applied in grasses and lamina in other plants.

BLĂNCHED, whitened by absence of light; etiolated. Compare Chlorosis and Albinisu.

BLĂND, fair; beantiful.

BLĂSTE' $\mathbf{M A}$, the embryo aside from the cotyledous; also used for auy point of growth or budding part. (Rare.)

BLĂSTẼ'MAL, rudimentary; nascent. (Rare.)

BLĂSTŌCÄR'POǓS, applied to a fruit when the seed germinates within the pericarp, as sometimes occurs in the mangrove. (Rare.)

BLĂSTōcŏL'LA், the gunmy substance on many buds, as on the horse-chestnut. 
BLĂSTŌĞÉN'ESÍs, reproduction by buds; gemmation. (Obs.)

BLĂS'TŬS (obs.), see BUD and Plumule.

BLIND, applied to a malformation, chicfly in certain cultivated plants, as cabbage and caulitlower, in which the stem terminates without producing a head or intlorescence. A "blind bud" is one which fails to develop. To "go blind" is to fail to produce flower-buds where expected.

BLIS'TERED, see BULLATE.

BLOOM, a coating on the surface of fruits, leaves, etc., often grayish or bluish in color, consisting of minute, waxy particles in the form of filuments, granules, or layers. See Gladcous.

BLǑSSOM-BUD, see FLOWERBUD.

BLŏTCHED, having distinct irregular spots of color. Compare CLOUdED.

BLǓNT, obtuse.

BŌAT'-SHĀPED, see NAVICULAR. BŏB, a popular name for the inflorescence (thyrse) of sumach.

BŌLE, the body of a tree.

BōLL, a globular pericarp, as that of cotton.

BŌLT (Hort.), to run prematurely to seed, as carrots when they seed the first year.

$\mathbf{B O} \mathbf{N}^{\prime} \breve{Y}$, hard, brittle, and close in texture, as the stone of the peach.

B00T, a popular name for the sheath of grains and other grasses.

BÔR'DẼR, the expanded portion of a gamopetalous corolla, consisting of the united limbs. See also Bordered Prt.

BÔR'DẼRED, having the margin different from the remainder in form, color, or texture.

BÔR'DẼRED PIT, a thin spot or opening in a cell-wall covered on each side by a thickened convex body having a central perforation; areolated dot; cliscoid marking. Bordered pore of Gregory. These markings are characteristic of the wood-cells of Coniferæ. The border is the more or less di. lated central portion of the pit or passage between the cells.

BÔR'DẼRED PŌRE, see BORDERED PrT.

Bǒss, a rounded protuberance.

BŏSSED, having a boss. Compare UMBONATE.

BŎS'TRY̌CHOID, ÇȲME see HELICOID CYME.

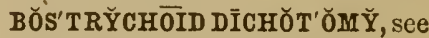
HELICHOID DICHOTOMY.

BŎS'TRY̌X, see HeLICOID CYME. BŌTĂN'ǏCÁL ǴĒOG'RĂPHY̌, see Geographical Botany.

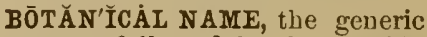
name followed by the specific name.

BŌTĂN'ǏCÅL NŌMENCLĀT'T̄RE, an account of the names of plants, and of the laws for their applicatiou.

BŌTĂN ǏCẢL TẼRMǏNŏL'ǑGY̌,an account of the special words used in describing plants.

BŌTĂN'ǏC GÄR'DEN, a collection of growing plants systematically arranged for the purpose of study.

BǑT'ĂNİZE, to seek for growing plants for the purpose of botanical investigatiou.

BŎT' $\mathbf{A} \mathbf{Y Y}$, the science of plants; phytology. See Strdctural, Phisiological, and Systematic Botany, Botanical No- 
MENClature, and BotaNicaL 'TERMINOLOGY.

BǑTHRĔN'CHY̌MȦ (obs.), see Pitted Tissee.

BǑT'RǓS, : ter like that of the grape.

BǒT'RȲoID, having the form of a bunch of grupes; botryoidal; botryose.

BǑT'RY̌ŌSE, see BOTRYOID.

BŎTRYัOI'DĂL, see BOTLYOID.

BǑT'TLE-SHĀPED, see LAGENIFORM.

BŎTÜ'LI-FôRM, see ALLAÑTOID.

BRĂ€H'ǏĀTE, appliell to branches which are decussate and spreading, as in the ash, and sometimes improperly to those which are long and willely spreading, but not decussate.

BRĂ€HY̌P'ŌDOǓs, short-stalked.

BRĂCT, a leaf of an inflorescence, generaliy subtending a tlower or flower-bramch. Bracts are intermediate in position between foliage leaves and tloral leaves, and are usually much smaller than the ortinary leaves, and in other respects more or less modified.

BRĂC'TẼ் (pl. Brăc'těæ), see BRACT.

BRĂC'TEAL, of the nature of a bract.

BRĂC'TĒATE, furnished with bracts; subtended by a bract or bracts; bracted.

BRĂCTÉ'0̄LA் (pl. Bracteolæ), see BRACTLET.

BRĂC'TĒöLĀTE, furuished with bractlets.

BRĂC'TĒōLE, see BRACTLET.

BRĂC'TĒŌSE, having many or conspicuous bricts.

BRĂCT'L ĚT, a small bract, or bract upon a pedicel or secondary branch of an intlorescence.

BRACT'LĚSS, without bracts.
BRÃIRD, to germinate. (Scotch.)

BRÁNCH (n.), a division of a stem or other elongated organ; secondary axis.

BRẢNCH (v, i.), to produce branches; to ramify.

BRẢNCH'LĚT, a little branch or subdivision of a branch; twig.

BREĀK (v. i.) (Hort.): (1) to rlepart willely from the type and suddenly produce a new viriety (nearly the same as sport); (2) to "bolt" or run prematurely to seed, as a biemnial the first year; (3) to put forth new buds or leaves.

BREAST-WOOD (Hort.), branches which project outward from a wall or espalier.

BRẼATH'ǏNG-PŌRE, see STOMA.

BREED, see RACE.

BRI'DLES, strings of protoplasm which often connect the nucleus with the layer of protoplasm next the cell wall.

BRÍS'TLE, a stifl, short hair or liair-like body.

BRIS'TLE-POINT'ED, ending in a bristle; terminating gradually in a fine sharp point, as the leaves of many mosses.

BRǏS'TLY̌, beset with bristles.

BROOD'-BUD, a deciduous leafbud capable of growing into a new plant, such as the bulbils of the tiger-lily and the deciduous buds of certain lycopodiums; also applied to the soredium of lichens.

BR $\overline{0 D} D^{\prime}-C E L L$, any reproductive unicellular body produced asexually which separates from the parent plaut, as the gonidia of fungi.

BR00D'-GÉM'Md, see GEMMA.

BROWN'ǏĂN MOVEMENT, a trembling movement common to all minute particles sus- 
pended in a liquid. Callecl also Brunonian movement, Pedesis, Non-vital wotion, and (improperly) Molecular movement. 'The caluse is not known.

BRŪN'NEǓS, deep brown, a mixture of dark gray and red.

BRŬSH'-SHĀPED, see ASPERGILLIFORM.

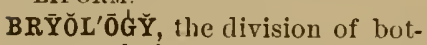
any relating to mosses; muscology.

BŬCK'LER-SHĀPED, see ScUTATE.

BŬD, an undeveloped stem or branch, or its extremity, bearing rudimentary leaves which are specially modified for its protection. See LEAF-BUD, Flower-Bud, and Gemra.

BŬD'DING, putting forth buds or gemmæ. Also applied to Pullulation, which see.

BŬD'LĔT, a little bud attached to a larger one.

BŬD-RƯ'DIMMĚNT, the special cells which originate the leafbearing axis in the pro-embryo of Characex.

$B U D^{\prime}-S C A \bar{A} L E$, one of the modified leaves of a bud; perule.

BŬD'-SPŌRT, see BUD-VARIATION.

BŬD.VĀRÍ $\bar{A}^{\prime} T I O N$, the development of a bud in a manner unusual to the species or variety, and different from the other buds upon the plant. It may be the production of a new variety or a reversion to an earlier form. Bud-variations, or "bud-sports" as they are often called, may usually be propagated by division, but their characters are seldom retained when grown from seed. Compare Seed-variation.

BŬD-VĂRI'ETÝ, a variety which originated by bud-variation.
BŪGLE-SHĀPED, having the shape of a bugle bead;-a form varying from oblong to obovoid. Used in describing the fruit of certain cranberries.

BŬLB, a bud with thickened scales containing uutriment for its development, thus differing from ordinary buds, the scales of which are for protection only. Bulbs are usually subterranean.

BŬLBĀ'ÇEOǓS, having bulbs; bulbous.

BŬLBED, in the form of a bulb; bulbaceous.

BǓL'BĚL, SEe BULRLET.

BŬLBǏF'EROǓS, bulb-bearing; bulbous.

BŬL'BĬL, SEe BULBLET.

BŬLB'LĚT, a little or secondary bulb, especially one above ground, as in some lilies and ferns; bulbel; bulbil; bulbule. See Clove.

BŬL'BŌSE, bulb-like in shape or structure.

BŬL'BŌ-TŪBER, see CORM.

BŬL'BOǓs, producing bulbs, growing from bulbs, or bulbose.

BŬLB-SCÃLE, one of the thickened scale-like leaves of a bulb.

BŬLB, TŪ'NǏCĀTĚD, see TUNICATED Bulb.

BǓL'BŨLE, see BULBLET.

BŬL'BŬS, the swollen base of the stipe in mushrooms.

BŬL'LĀTE, having the surface blistered or puckered, as the leaves of the Savoy cabbage, the spaces between the veins of which are concave on one side and convex on the other.

BǓL'LIFÔRM CĚLLS, see HYGROSCOPIC CELLS. 
BŬNCH, an indefinite cluster or tuft.

BŬN'DLE-SHĒATH, a layer of closely united thin-walled parenchyma partly or wholly surrounding each fibro-vasenlar bundle or continuous around the fibro-vascular cylinder; phlvem-sheath.

BÛR, a seed or head bearing hooked or barbed appendages which serve for its attachmeut to various avimals, thus securing its dissemination.

BÛRSÍC'ŪLĀTE, pouch-like or furnished with pouch-like appendages.

BÛ̉RSIC'ŪLȦ (pl. Bursic'ulæ), au old term for the stigmatic chamber in orchids.

BÛRSICC'ŨLÃTE, having a bursicula or small pouch.

BUSH, a shrub, especially if dense and low. Shrub implies the habitual form or limit of growth, but a bush may grow into a tree.

BŬT'TERFL $\bar{Y}$-SHĀPED, see PAPILIONACEOCS.

BUTTERY, applied to fruits, especially pears, the Hesh of which is soft and yields readily to the pressure of the teeth, as in the IVhite Doyenné and Seckel pears. The texture is in some respects intermediate between Breaking and Melting, which see.

BŬT'TON (v. i.) (Hort.), to form small heads prematurely, as camlitlower.

BĪÇY̌C'LǏC, having two cycles or whorls.

BY̌SSĀ'CEOǓS, resembling or consisting of fine filaments like cobweb, as the mycelium of mushrooms.

BY̌S'SOID, resembling bissus. BY̌S'SÚS, an old name for the filamevtous mycelium of certain fungi.

CĂDŪ'COǓS, falling early, as the ealyx of the poppy.

CERƯLĚS'CGENT, see CGEULESCENT.

C ERƯ'LEǓS, see CarulEUS.

CE'SIOǓS, pale bluish-gray; lavender-colored.

CÆSPǏT'ĚLLŌSE, diminutive of Cæespitose.

CÆS'PİTŌsE, see CESPITOSE.

CĂLẢTHǏD'ĬŬM (obs.), see Capituluar. Formerly applied to the head of flowers in Com. posite, or sometimes to the involucre only.

CĂLĂTH'ǏFÔRM, bowl-shaped, with the margin more or less flariug, like a fruit-dish or Hower-basket.

CĂL'CÄR, see SPCR.

CĂL'CÄRĀTE, having a spur, as the Hower of larkspur; spurshaped.

CĂLCA'Á̄̄ ŬS, of a dull chalkwhite color; growing in chalky or limestone soils.

CĂL'ÇËIFÔRM, see CALCEOLATE. CĂL'ÇĒóLĀTE, slipper-shaped, as the lip of Cypripedium; calceiform; solerform.

CĂL'ÇĬFôRM, powdery, like chillk or lime.

CĂLÇIV'ŌROǓs, eating into lime rock, as certain licheus.

CĀLǏ C'ŨLÄR, c u p - s h a p e d. (1Rare.)

CĀLǏI'U'UAATE, see CALYCULATE. CA'LIX, see CALYX.

CĂL'LI (pl.), see CALLUs.

CĂL'LŌSE, having hardened spots or protuberances; callused.

CĂLLǑS'ǏTY̌, a hard or thickened spot or protuberance; callus; wart. 
CĂL'LŬS (pl, Calluses or Calli), (1) a hard or thickened spot or protuberance; callosity: the new formation upon an injured surface, as seen at the end of a cutting: (3) a thickened deposit of formative material in the pores of the sieve-plates in certain trees in autumu: (4) a tem applied to an extension of the flowering glume in grasses below its point of iusertion, and which is grown to the axis or rachilla of the spikelet and separated from the free portion by a more or less distinct furrow. It is frequently covered with hairs or bristles (us in Stipa) which serve for atticliment to other objects to secure the distribution of the seed. The Callus is sometimes present in the empty glumes also.(Scribner.)

CĂL'VoǓs, bald; having a surface on which hairs are usually present destitute of them, as in an achenium withont a pappus.

CĂLY̌CĂN'THĒMOǓS, ha ving petaloid sepals.

CĂLY̌CĂN'THĒYY, a partial or entire conversion of sepals into petals.

CĂLY̌ÇIFLō'RĂL, having the calyx free from the ovary, and the stamens (and therefore the petals also) iuserted on the calyx. Compare TrateamiFLoRAL and CoRollifloral.

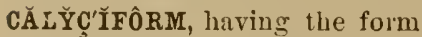
or position of a calyx.

CĂLY̌Ç'ǏNAL, SEe CALTCINE.

CĂL'Y̌ÇINE, pertaining to or situated on il calyx; calyciual.

CĂL'Y̌CLE, a whorl of bracts forming a secondary or accessory calyx outside the true calyx.
CĂL'Y̌CLED, haviug a calycle. CĂL'Y̌CoID, resembling a calyx. CĀLY̌C'ŪLĀTE, lıaviug a calyculus.

CĀLY̌ C'ŪLĀTED, see CALYCU LATE.

CĀLY̌Y'ŪLǓS, a set of involucral bracts resembling a calyx, as in Dianthus.

CĀLY̌P'TRA, the membranous hood or veil covering the capsule in mosses. It consists of the ruptured archegonium carried up by the growiug sporophore. The term is also applied to the root-cap, which see.

CĀLY̌P TRĀTE, lıaving a calyptra or similar coveriug.

CĀLY̌P'TRǏFôRM, shaped like a calyptra or candle extinguisher, as the calyx of Eschischoltzia.

CĀLY̌Y'TRŎGEN, a special layer of cells in certain plants from which the root-cap is developed. (Jancewski.)

$\mathbf{C A} \bar{A}^{\prime} \mathbf{L Y X}$, the outer set of tloral leaves between the bracts, if any, and the corolla. When there is but one set extermal to the stamens, it is usually called calyx or perianth.

CÁ'LY̌X TÜBE, a tube of united sepals adherent to the ovary or enclosing the other parts of the flower. As the elevated margin of the receptacle sometimes forms a portion of this tube, the term "receptacular tube" is also applied to it.

CĂM'ÁRÁ (pl. Căm'àræ), an inclefinite term formerly applied to various fruits having more or less membranous carpels, as the Ramunculus and apple. Also applied to a single carpel of such a fruit. 
CĂM'BǏAL, pertaining to cambiunl.

CĂM'BǏFôRM, said of narrow jrismatic thin-walled cells, like those characteristic of cambium.

CĂM'BĬ $\mathbf{M}$, a layer of meristem belonging to the fibrovascular system, between the xylem and phloem. In exogens it is permanent, and forms the continuous ring or layer of soft growing tissue between the wood and inner bark, from which the new growth of each is derived. It was formerly considered merely a viscid secretion, often called " descending salp." but it is now known to be composed wholly of young, easily broken cells filled with protoplasm or formative matter.

CĂM'BĬŬM LĀY'ER, see CAMBIUYI.

CĂM'BĬŬM RING, see CAMBIUM.

CĂMPĂN'ǏFÔRM, see CAMPANULATE.

CĂMPĂNIL'ǏFÔRM, see CAMPAX̃ULATE.

CĂMPĂN'ŪLĀTE, bell-shaped, as the corolla of the larebeil.

CĂMPES'TRAL, growing mainly in uncultivated fields.

CĂMPŪLITT'RŌPOǓS (obs.), see CAMPYLOTROPOUS.

CĂM PY̌LŌSPẼR'MOǓS, having the edges of the seed rolled inward to form a longitudinal groove or furrow, as in sweetcicely and some other Umbelliferæ.

CĂMPY̌LŎT'RŌPAL, see CAMPYLOTROPOES.

CĂMPY̌LǑT'RÖPOǓS, applied to ovules or seeds which are - curved upon themselves so that the micropyle is near the chalaza, as in Cruciferæ; cam. pylotropal.

CĂNĂL'-ÇELLS, an axial row of cells in the neck of the archegonium the counecting septa of which disappear, forming a canal filled with mucilage for the passige of the antherozoids.

CĂNÄL ĬC'ŨLĀTE, channelled.

CĂNÁLĬC'ŨLǓS (pl. Cănảlíc'ūlīi), a channel.

Ch̆N'ÇELLĀTE, haviug open network; lattice-like.

CĂN'DǏCĂNT, see AlBEscent.

CĂN'DǏDŬS, Latin for pure white.

CĀNE, the stem of reeds and other large grasses. Applied in horticulture to the stems of raspberries and blackberries, and one-year-old stems of grape-vines.

CĂNĚS'ÇENT, hoary (gray or whitish) from a coating of fine hairs; canus; incanus; iucanous; incanescent.

CĀ'NŬS, see CANEscent.

CĂP, see PILEUS.

CĂPĬLLĀ'ÇEOǓS, see CAPILLART.

CĂPĬL'-LĂMENT (rare), see FILAMENT.

CĂP'ǏLLĂR $\breve{Y}$, Iong and narrow like a hair; said of a tilament or channel.

CĂPĬL'LIFÔRM, see CAPILLARY.

CĂPǏLLITT'Ǐ ments, often in the form of network, among the spores of puff-balls and some other fungi.

CĂP'ǏTĀTE, furnished with a globose head; growing in " liead.

CĂPǏTĚL'LĀTE, diminutive of capitate; capitular.

CĂPİT'ŨLAR, see CAPITELLATE. 
CĂPǏT'ÜLIFÔRM, in the form of a small liead.

CÂPİT'ŪLŬM (pl. Căpĭt'ūlà), a dense flower-cluster, as in the clover or sunflower; a head of any kind.

CĂP'RĒOLLATTE, having tendrils; cirrhose.

CĂPRË'ŎLŬs (pl. Căprē'ǒlī), see TENDRIL.

CÁPRIFĬCĀ'TION, (1) the fertilization of the fig, by liand or by means of iusects. Sometimes extended to the artificial fertilization of other fruits. (2) The proeess of acceleruting the ripeniug of tigs by placing on the cultivated plant brauches of the wild fig (eaprificus). A hymenopterous inseet found on the wild plant enters the fruit to lay its eggs, causing it to ripen earlier. The same result is obtained by the practice of pricking the green figs with a needle dipped in olive-oil; also by the application of a drop of the oil to the eye of the fig. There seems to be some doubt as to whether the result from caprification by means of the wild fig is due to fertilization, or the punctures of the inseet, or to both.

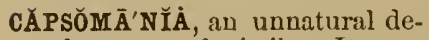
velopment of pistils. It may consist of excessive multiplication or of any alteration in form which impairs their function.

CÁP'SŪLAR, pertaining to a capsule.

CĂP'SŪLĀTE, enclosed in a cap. sule.

CĂP'SŪLE, any dry dehiscent fruit, especially one which is superior and polycarpellary. The sporangium of mosses is usually called a capsule.
CÃPSŪLǏF'EROǓs, bearing capsules.

CÄRBǑN $\bar{A}^{\prime}$ ÇEOǓs, appearing as if burnt.

CÄR'ÇERŨLE, a dry fruit formed from a polycarpellary ovary, the carpels of which separate when ripe into indehiseent. few-seeded cocci, as mallow; careerulus. Compare ScHrzoCARP.

CARÇĔR'ŬLŬS, see CARCERULE.

CARÇITTH'ǏUM, au old term for Mycelium.

CÅĬCǑL'ŌGY̆, the study of the genus Carex.

CA'RǏ̀s, au old term for decay.

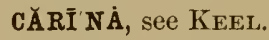

CĂRI'NȦL, pertaining to a keel.

CĂRI'NÁL 死STǏVA'TION, when the cariua embraces the other parts of the flower.

CĂRI'NA்L CĂNĂL', a lacuna in the xylem of a fibrovascular bundle, as iu Equisetum. Compare Vallecular Canals.

CĂR'ǏNĀTE, kcel-slıaped, or having a longitudinal ridge like a keel; keeled.

CĂR'ǏNĀTED, see CARINATE.

CARǏǑ'SǏs, see CARYopsis.

CĀ'RǏOǓs, decayed. (Rare.) Compare CARIEs.

CÄR'NẼOǓS, flesh-colored; pale red. Compare Carnose.

CÄR'NĒUÚS, SEe CARNEOUS.

CÄRNǏV'ŌROǓS, sEe INSECTIVOROUS.

CÄR'NŌSE, fleshy in texture. More firm than succulent or pulpy.

CÅR'NOŬS, pertaining to flesh; fleshy.

CÄRPÁDE'LIŬM, see CREMOCARP. 
CÄR'PEL, a simple pistil or one of the elemeuts (moditied leaves) of a compound pistil.

CÄR'PELLĀRY̌, pertaining to a carpel.

CÄRPĚL'LŬM (pl. Cärpěl'là), see CARPEI.

CÄR'PǏD, a ripe carpel, especially if sepurable.

CÄRPǏD'ǏŬ, a carpid or carpel.

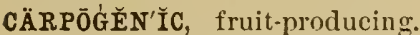
In Floridex applied to the special cell (or cells) of the procarpium which develops into the carpogonium.

CÄR'PŌGŎN, see CARPOGONIUM.

CÄRPŌGŌ'N ǏUM, the female organ, usually multicellular, of Carposporea before fertilization. Compare Oogonitur.

CÄR'PŌLİTE, a petrified fruit; lithocarp; carpolith.

CÄRPǑL'ÓGÝ, the part of botany which relates to the structure of fruits. Compare PosoloGr.

CÄR'PŌPHŌRE, the stalk of a sporocarp; a stalk elevating the gynecium above the rest of the Hower (gynopliore); a prolongation of the axis between the carpels, as in Umbellifera.

CÄR'PŌPHY̌LL, see CARPEL.

CÄRPŌPHY̌L'LŬM (pl. Cärpōphy̆l' là), see (ARPEL.

CÄR'PŌSPŌRE, a spore produced in a sporocalp. De Bary extends the term to all those produced on a sporophyte, thus including the spores of ferus. This makes it equivalent to the term "spore" as used by Sachs.

CÄR'PŌSTŌME, the opening in a sporocarp throngh which the spores are discharged.

CÄRTǏLĂG'ǏNOǓs, fil'm and tough like cartilage.
CĂR'ÙNCLE, a partial aril growing from the hilum, as in Polygala; strophiole.

CĂRŬN'CŪLȦ, see CARUNCLE.

CĂRŬNN'CŨLÄR, see CAIUNCULA'TE.

CĂRUัN'CŪLĀTE, having a caruncle or the form of a carluncle; caruncular; carunculous; carunculated.

CĂRŬNN'CŪLĀTED, see CARUNCULATE.

CĂRŬNِCŨLOŬS (rale), see CARUNCULATE.

CĂRY̌ŌÇỸNE'SĬS, sce KAIYOKINESIS.

CĂRY̌ŌPHY̌LLĀ'CEOǓS, pinklike; especially having five petals with long claws, as in the pink fimily (Caryophyllacex).

CĂRY̌ǑPH'Y̌LLOŬS, see CARY. OPHXLLACEOUS.

CĂRY̆ŎP'SISS, a dry one-seeded indehiscent fruit, with the pericarp thin and adberent to the seed, as in wheit and most other Graminea; cariopsis.

CĂSQUE, see GALEA.

CĂSSĬD'ẼOǓS, a term applied to an irregular corolla having the upper petal broad and helmetshaped as in Aconitum.

CĂST $\bar{A}^{\prime}$ NẼOŬS, chestuut-colored.

CĂS'TRĀTE (adj.), said of a stames which contains no anther, or no good pollen.

CĂS'TRĀTE (v.), to remove the anthers.

СĂTĂBŎL'ǏC, see КАTABOLIC.

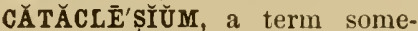
times applied to an achenium like Mirabilis, being a onecelled, one-seeded fruit within a hardened calyx.

CĂTĂCōRŏL'LȦ, a secondary co. rolla sometimes found inside or outside the true corolla. 
CĂTĂPĔT'ĂLOŬS, having the bases of the petals in a polypetallous corolli adherent to the bases of the stamens, as in Malva.

cӐT'ǍPHY̌L, a scale-like leaf, as on buds, rhizomes, etc. Compare EUPHYLL.

CĂTĂPHY̌L'LĂRY̆, scale-like, as the perules of a bud or the rudimentary leaves on a rootstock.

CĂT'Ẽ ĀTE, see CoNCATENATE. CĂTĚN'ŪLĀTE, see CONCATENATE.

CĂTH'0̄DĂL, see CATHODIC.

CĂTHŎD'ǏC, applied to the edge of a leaf which is entered by an ascending spiral. In a right-luanded spiral it would he the left edge and vice versa. Also spelled Kathodic. Compare A Nodrc.

CĂT'KIN, see A.ENT.

CA U'DATE, having a long termination like a tail.

CACU'DĀTED, see CAUDATE.

CA U'DEX (pl. Cạu'dexes or Cạu'diçess), the trunk of a palm, a tree-fern, or other arborescent endogen or acrogen; an upright root-stock; the persistent base of various herbaceous perennials (in this sense obsolete). Formerly applied to the trunk of any tree.

CAU'DǏCLE, a little stalk, as that to which each pollen-mass in orchids is attached.

CAUDǏC'ŬLA், see CAUDICLE.

CẠULÉS'CENT, having a distinct leaf-bearing stem.

CA U U'LICLE, the first internode, or portion of the stem below the cotyledons and above the radicle or beginning of the true root; tigellum; cauliculus, usually called radicle. Seldom applied to the part after the plant has developed.

CẠU'LǏCŪLE, see CAULIClE.

CẠULÍC'ŪLŬS (pl. Cạulic'ūūî), see CAULICLE.

CẠULIF' ̌rROǓs, having a stem; caulescent.

CẠU'LIFÔRM, stem-like.

CẠULIG'ÉROǓs, borne upon the stem.

CAUU LINE, pertaining to the stem; belonging to the stem, or main stem, as cauline lenves.

CAULINE BŬN'DLES, fibrovascular bundles confined exclusively to the stem and not connected with those in the leaves. Compare Comson Bundes.

CAUU'LIs, the stem; especially the main stem in herbaceuus plints.

CẠULŌCÄR'POǓS, producing fruit upon a permanent stem, as ordinary trees and slirubs.

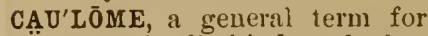
stems of all linds, whether loving the ordinary form and functions of stems or not. Compare Phyllone.

CAULŌ'MER, a name proposed for one of the secondary axes which form a sympodium.

CẠULŌT $\mathbf{A} X^{\prime}$ Iss, the arrangement of the brauches upon a stem.

CĂ $\mathbf{V}^{\prime} \check{I} T Y$ (Hort.). the depression in the stem end of an apple. Compare Basin.

ÇĚLL, (1) one of the structural elements of living bodies, by the multiplication of which growtl is effected. In plants the cell usually appears as a closed sac surrounded by a firm wall of cellulose and containing the essential element, protoplasm, and usually a nu. cleus, the active agent in cell- 
division. See Cellulose, Cell-ivall, Cell-sap, Pro-

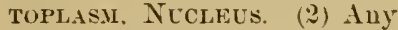
cavity, as that of au auther or ovary.

ÇELL-FAMILY, a group of cells of common origiu: used maiuly among the lower alga; colony. See Coenobrum.

ÇĚLL-Fi'BRE, see NúcLEAR FIBRIL.

ÇELLIF' ĔROŬS, bearing or producing cells.

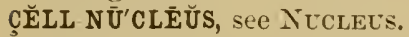
ÇELL-PLATE, the early condition of a cell-wall at the equator of a dividiug nucleus, formed by the fusion of a series of thickenings of the spindle-fibres called by Strasburger Dermatosomes.

ČLLI, PRĪMÔR'DIAL, see PRIIORDCAL CELL.

Ç̌LL SĂP, fluid in living cells which separates from the protoplasm as one or more vaclloles; cytenchyma. Compare VAsCCLAR SAP and DEUTOPL.AS.Y.

ÇĚLL-TÍS'SŪE, tissue composed of cells as clistinguished from vessels. See CElluldi Tis. SUE.

ÇĔL'LŪLAR, composed of cells; pertaiuing to cells as distiuguished from vessels; having the cells latgre and soft; containiug cavities of auy lind; porous.

ČEL'LŪLAR BÄRK, see MEsoPHLEUM.

ÇĔLIŪLAR ĚN'VĔLŌPE, see MESOPHLCEUM

ÇẼL'LŨLAR PLÁNTS, those which contaiu no fibrovascular tissue, as fungi and algae; thallophiptes.

ÇĔL'LŪLAR SPŌRE, see COAPOUND SPPUIE.
ČEL'LŪLAR SY̌S'TĚM, the cellular portion of a plant as distinguished from the fibrovascular.

ÇĚL'LŪLAR TǏS'SŪE, tissue iu which none of the cells are moditied into ducts or vessels. Especially, tissue composed of cells which are large aud loose, like the pulp of fiuits; parenchyma. Compare VASCELAR Tissue.

ÇĚL'LŪLE, a small cell.

ÇĚLLŪLIF'ẼROǓs, beariug or produciug little cells.

ČEL'LŪLŌSE, primary cell-wall substance; the material forming most of the dry matter of plauts. It is seen nearly pure in cotton-fibre and in the cellwalls of most plants while young. There are many modifications of cellulose, amoug them Lignin in older wool and Suberin in bark.

ÇĚLL-WẠLL, a sac enclosing the liviug contents of a cell.

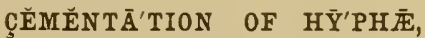
their inseparable union by a cementing substance; concrescence. (DeBary.)

ÇĚM' ̌̌NT-DǏSK, Mïller's term for the glandular disk or retiuaculum of orchids.

ÇENĂN'THY̆, the suppression of stamens and pistils.

CĚNŌ'BĬŬM, see C'СуовIUM.

ČẼNóGENĚ T'ǏC, secondary.

ÇĚN'TRÁL CELLL, the cell of an archegonium, from which the oosphere originates. Compare EMBRYO-SAC.

CÉN'TRÁL CÔRD, a cord or bundle of elongated thiu-walled cells at the centre of the stems, leaves, and fruit-stalks of many mosses which serves for the transfer of water; tissue-cord. 
CĽN'TRẢL CYYL'ǏNDĚR, the portion of the tissue of roots and stems within the cortex. It includes the medullary and fibrovascular systems, - used mainly in roots. Compare Fibirovascular Cylinder.

GĚN'TRĬC, a term applied to such leaves as show no cousiderable difference between the internal structure of their upper and under sides. Compare BrFACIAL.

CĚNTRIFF'ŨGẢL, saiı of an inflorescence in which the terminal flower blossoms first: definite; determivate. Applied to a radicle which is turned toward the side of the fruit, or to anything else which poiuts ontward.

CóNTRÍP'ÉTÁL, said of an inflorescence in which the lower or outer Howers blossom first; indefinite; indetermiuate. Applied to radicles or seeds which point toward the axis of the fruit. Now little used in the latter seuse.

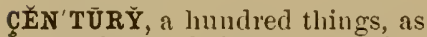
a package of plants containing a hundred specimens.

ÇĔPHĂL ĂN'THǏŬM, see ANTHODIUM.

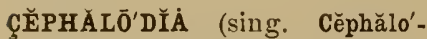
diŭm), ontgrowths of a licheu thallus in which algal cells are situated.

ČEPH'ĂLOID, capitate or headshaped.

ÇERA' $\bar{A}^{\prime}$ CEOǓS, wax-like.

ÇÊRAMĬD'ǏUM (pl. Ceัrảmǐd'ǐà), the ovate or urn-shaped capsule containing the spores in the red algæ (Florideæ).

CELIF'EROǓS, producing wax.

ČẼR'NOǓS, nodding, curved over near the top, as the flower of narcissus upon its stem; nutant. Compare Droopixa.

ÇÊR'NŬOŬS, see CERNots.

ÇẼR'NŬŬS, see CERNOUS.

ÇE'SIOǓS, see C Fisious.

Č̌s'PİTŌSE, iu tufts or dense bunches; crespitose: tufted.

ÇĚS'PǏTOǓS, see CEsPITOSE.

ÇÉSPǏT'ŪLŌSE, iu small tufts or bunches.

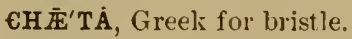

CHÁFF, the glumes aud palets of graius and other grasses; the bracts which subtend each flower in the head of Compositæ, ete.

CHĀIN-GĔM'MÁ, a kind of gemma found in Alucorini having the form of a septate confervoid filament, the segments of which are capable of germination; sprouting gemmal. (DeBary.)

$\mathbf{C H} \dot{A} \mathbf{L} \overline{\mathbf{A}}^{\prime} \mathbf{Z} \dot{A}$, the base of the orule or place where its coats unile with each other aud with the mucleus. In orthotropous sceds it corresponds with the lilum.

CHĂP'LĔT, a series of objects arranged like beads on a striug, as the spores of Cystopus.

EHĂR'ĂCTẼR, whatever distinguishes a plant or group of plants from others; a descrip. tion composed of the distivetive features of a species or other group. See SPEcific (Haracter, Gexeric CharACTER, etc.

CHÄRTÁÁCEOǓs, of the texture of parchiment or writing-paper.

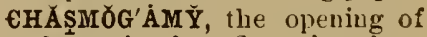
the perianth at flowering time. (Rare.)

cHǏNK'Y̌ (Tuckelman), see RIMOSE. 
ЄHLAMYั'DŌSPŌRE, a lind of thick-walled spore formed asexually in Mucorini by freecell formation within the hyphr. The term is also applied to certain thick-walled spores in protophytes, and occasionally elsewhere.

EHLŌ'RANTHY̌, the conversion of the parts of a flower into green leaves.

€HLŌRōLEŨ'C̄'TE, see ChLOro PLAST.

EHLŌ'RŌPHY̌L, see CuLoroPHYLL.

ЄHLŌ'RŌPHY̌LL, the green coloring matter of plants.

€HLŌ'RŌPHY̌LL-BŎD' body (plastid) in the cells of plants containing the chlorophyll; chlorophyll-grauule; chlorophyll-corpuscle; chloroplast; autoplast; chloroleucite. See Plastid and ChromatoPHORE.

€HLŌ'RŌPHY̌LL - CÔR'PǓSÇLE, see CHLOROPHYLL-BODY.

€HLŌ'RŌPHY̌LL-GRĀIN, see CHLOROPHYLL-BODY.

€HLO' RŌPHY̌LL GRAN' ŪLE, see CHLOROPHYLL-BODY.

€HLŌ'RŌPHY̌LL-VĚs'Ǐ́CLES, see PrRenoids.

€HLO'RŌPLĂST, see CHLOROPHYLL-BODY.

€HLŌRŌ'sǏs, an abnormal absence or dininution of the green coloring matter of plants; albinism. Compare Etiolation.

€HÔR'DA PǏSTǏLLĀ'RǏs, a fibrovascular bundle in the style. (Obs.)

€HōRǏPĔT'ẢLOǓS, see PoLYPETALOUS.

€HōRǏsĔP'ÁLOǓS, see PoLYsEPALOUS.

$\mathbf{E H} \mathbf{O}^{\prime} \mathbf{R}$ ÍsÍs, the production of two or more organs in the position of one. It is considered in most cases to be a branching of rery enrly origin. 'The condition may be normal or abnormal. See CollateraL and Traxsverse Chorisis. Compare UNLiNing.

€HōRISTǑPH'Y̌LLOǓS, separateleaved. (Rare.)

ЄHRŌMĂT'Ǐc, capable of being colored by staining agents; pertaining to color.

EHRŌ'MÁTIN, that part of the protoplasin of the cell, mainly in the nucleus, which is readily and deeply colored by stitining agents. It forms the chief portion of the granular fibrils called "nuclein" or "uucleoplasm."

ЄHRŌMÁT'ŌPHŌRE, the protoplasmic body (plastid) in which chlorophyll or other coloring matter is produced; color-granule; chromoplast; chromoleucite. The term is also extended by some to all plastids. See CHLOROPHYLL-BODY.

€HRŌMǏD'ǏŬM, a term sometimes applied to the gouidium or algal host of lichens.

ЄHRŌMŌLEŨ'C̄TE, see CHROMATOPHORE.

ЄHRŌ'MŌPLĂST, see CHROMATOPHORE.

€HRŌMŌPLĂS'TǏD, see CHROMATOPHORE.

CHRŌ'MŌSŌME, one of the serrments of the nuclear filament in karyokinesis.

EHRǑM'ŪLE, a terin applied to all coloring pigments found in living plants.

ЄHRǑN'İZŌÖSPŌRE, one of the microzoogonidia produced in vast numbers in Hydrodictyon - so called, because they rest for several weeks or more be. 
fore germinating; chronispore; chrovizoospore.

ÇĬC'ĀTRǏÇE, see CiCATRIX.

ÇICA'A'TRİX (pl. Çìcătrī'çēs), a scar left by a falling leat or other organ.

CIĚN'€HY̌MA, a șstem of intercellular spaces. (Kíchler.)

Çİ'İA (siug. Çil'iǔm), Lairs or bristles forming a row or fringe: the tail-like appendages of zoospores; single, fine, soft, hair-like termimal appendages of any kind. Compare FLAGELLA.

ÇǏL' İ $\bar{A} T E$, having cilia.

ÇIL'IATE-DĚN'TĀTE, lo a v ing teeth fringed with hairs.

ÇǏL'ǏÍFôRM, resembliug cilia.

ÇÍL'ǏǑGRĀDE, moving by meaus of cilia, as zoospores.

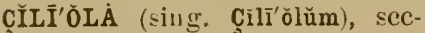
oudary or minnte cilia.

ÇǏL'ǏŬM (sing.), see CILIA.

ÇǏN'ÇINNĂL ÇȲME, see SCORPIOID CHAE.

ČIN'ÇĨNNĂL DĪ€HǑT'ŌMY̌, see SconploID DichotuMY.

ÇIN'CINN NUS, see SCORPIUID CYME ÇİNẼRÁ ÇEOŨS, a liıtle paler than Cinereous.

ÇÍNE' RẼOǓs, ash-gray.

ÇINẼRĔS'ÇENT, becoming ashgray; cineraceous.

Č̃NÊRT' TIOŬS, see CiNEREOUs. Ç' I'ON, see ScION.

Çİ'ÇINAAL, see CirciNate.

ÇİR'ÇINA ĀTE, rolled forwarl from the end, as the young leaves of many ferns.

ÇĨR'CUัMÇİȘED', divided in a transverse circular manner.

ÇIRCUัMNŨT $\bar{A}^{\prime} T I O ̌ N$, the act of bending around successively through different points of the compatss, as is done by the euds of twining vines, and in a less degree by other growing points; revolving nutation. See Nutation.

ÇİRCǓMSC̆İS'SILLE, dehiscing or dividing by a transverse circular line, as the fruit of purslaue.

ÇĨRCUัMSCRÍP'TION, an outline or boundary.

ÇǏRHǏF'ĚROǓS, having tendrils. See Cirrhose.

CǏR'RHǏFôRM, tendril-slıaped; cirriform.

CİR'RHŌSE, having tendrils; cirrhiferous; cirrhous; cirrous: cirrose; capreolate. Also, resembling a tendril or coiling like a tendril: tipped with a wavy filiform appendage; slenderly Hagellate.

C̆L R'RHŌSELY̌ PǏN'NĀTE, piunate with a terminal leatlet replaced by a tendril, as in the pea.

CĬR'RHOǓs, sce CIRIRIIOSE.

ÇİR'RHǓS (pl. Cir'rhì), a tendril; capreolus.

ÇǏRRǏF'ĚROǓs, see CIRRHIFEROUS.

ÇĬR'RǏFôRM, see C'IRIßIIFORM.

ÇİRĬG'ĚROǓS, producing tendrils. See CinfHose.

ÇİR'RōsE, see CirRHose.

CIIR'ROǓs, see CIRliHosE.

ČIR'RŬS (pl. Cir'rī), see CiRIrHus. ÇİSTŌMÁ, see C'ıs'TonE.

ÇǏs'TōME', a term sometimes given to a stomatic chamber when it exists as a kind of sac lined by a special layer of cells.

CLĂDOCÄR'POǓS, luaving the fruit in mosses on short lateral bra n c li es ; pleurocarpous. Compare Acrocarpous.

CLĂD'ŌDE, see PHYilocuadiur. CLĂDō'DǏŬM (pl. Clădōd'ía), see Phyllocladium.

CLĂD'ŌPHY̌LL, see PHYLLOCLADIUM. 
CLĂMP-ÇĔLL, see CLAMP-CONNECTIUN.

CLĂMP-CÓNNĚC'TION, a semicircular process combecting two adjoining cells of a hypha. In some cases it may communicate with but one of the cells, thit from which it origivated, in others its extremity becomes applied to the wall of the artjoining cell, at which point both walls are absorber, leaving a passage around the sep. tum between the cells of the filament. The process may become cut off from the originating cell hy a septum when it is called a "clamp-cell." It is found mainly in Basidiomycetes.

CLA்SS, a group of related orders.

CLȦSSIFǏCĀTION, the srstematic distribution of individuals into groups.

CLĂTH'RĀTE, latticed: furnished with openings like latticework; cancellate.

CLĂTH'RĀTE ÇĚLL, see SIEVETUBE.

CL $\bar{A}^{\prime} V \bar{A} T E$, club-shaped; gradually thickened upward or away from the extremity of attachment.

CLĂV' '̇FÔRM, see CLAVATE.

CLǍV'ĚLLĀTE, diminutive of Clavite.

CLĂV'ǏCLE, see TENDRL.

CLĂVǏC'ÜLẢ (pl. Clăvǐc'ūlæ), a term formerly used for teudril, especially a tendril formed by a petiole.

CLĂVǏC' ŨLĀTE, having a tendril. (Rare.)

CLĂV'ǏFôRM, see CLAVATE.

CLĂV'ŪLE, the club-shaped conjugating process in Iucorini. (DeBary.)

CLẠW, the stem or narrow base of a petal, as those of the pink; ungruis.

CLĚFT, having narrow sinuses reacling about half way to the base. Compare PARTED and DIVIDED.

CLEI'STŎCÄRP, an a s c o c a r p which is entirely closed, and from which the spores escape by its final rupture, as that of the Erysiphee.

CLEİSTŎG'ĂMOŬS, having closed fertilization: a term applied to certain more or less depauperate fluwers, sometimes underground, which never open, but ire self-fertilized, as in some violets; clandestine. Cleistogamons flowers sometimes accompauy flowers of the usual form on the sime plant.

CLEİSTǑG'ĂMY̌, self-fertilization without the Howers opening; closed-fertilization.

CLEİSTŎGĒNE, a plant which bears cleistogamous flowers. See above. It may bear flowers of the ordinary form also.

CLĚS'TILNE, see RAPHIDIAN CELL.

CLİMB'ǏNG, rising by laying hold of other objects in any way except by twining; scandent.

CLINĂN'DRĬŬM, the part of the column of orchids containiug the anther.

CLĬNĂN'THĬŬM, the receptacle of the flowers in Compositx; phoritutlium; elinium; anthoclinium. Compare AntroDIUMr.

CLǏNG'STŌNE, applied to varieties of the peach and other drupaceous fruits, in which the flesli when ripe is not readily separable from the pit. Compare FreEs'TONE.

CLINI I ' IUUM, the stalk or filanıent 
supporting a stylospore. (Tuckerman.)

CLǏN'ǏŬM, see ClinaNTHIUM.

CLĬNŌSPŌRĂN'ǴĬŬM, see PrCNIDIUM.

CLI'NŌSPŌRE, see STYLOSPORE.

CLİSTŌ-, see CleisTo-.

CLŌSED, applied to fibro-vaseular bundles in which all the cambium cells become permanent tissue, as in monocotyledons. Compare OPEN.

CLŌSED - FẼRTǏLǏZA'TION, see Cleistogamy.

CLŌSE-FẼRTǏLIZA' $\bar{A}^{\prime}$ TION, the fertilization of pistils by pollen from the sante Hower; self-fertilization.

CLŌS'ǏNG-MĚM' BRĀNE, the original unthickened cell-wall at the centre of a bordered pit.

CLOU'DĔD, having a pale ground with ill-defined patches of a darker tint gradually shading into it.

CLōvE, one of the small luulbs developed in the axils of the scales of a larger bulb, as in garlic.

CLǓB, one of the elements composing the pulp in the seet?cavities of the lemon and olange. It consists of a more or less oval body about one fourtl of an inch long filled with juice and attached by a stalk to the inner side of the cavity or cell. Morplologically, it is a pluricellular hair.

CLÜBBED (Hort.), applied to the stem of an apple when its base is enlarged and fleshy. Compare Clavate.

CLǓB-SHĀPED, see ClAvATE.

CLUัS'TẼR, an indefinite popular term, applied maiuly to suallfruits in which several fruits grow together in an inflorescence, as in the raceme of the currant. About the same as Bunch, but applied more often perluaps to locse collectious.

CLUัS'TẼR-CŬP, see ĖCIDIUM.

CLǓS'TERED, collected into or growing in a bunch, as the conglomerate flowers of dodder.

CLY̌P' $\bar{E} \bar{A} T E$, see SCUTATE.

CLY̌Y'PĒİFÔRM, see SCUTATE.

CŌẢÇẼR'VĀTE, see ACERVATE.

CŌĂD'ŪNĀTE, united at the base or farther; connate.

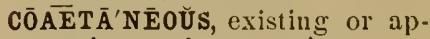
pearing at the same time; contemporineous.

CŌALĔS'CENCE, the complete union of similar things. The same as Cohesion when applied to orgitus. Compare Consu. GATION.

CŌẢLĚS'ÇENCE OF ÇĚLLS, the partial or entire absorption of the partition-walls of adjoining cells, as when the cavities of long rows of cells in a tissue become connected in the formation of ducts or vessels.

CōÄRC'TĀTE, crowded together; compact. Opposed to effuse.

CŌAT'Ẽ, composed of layers, or latving a rind.

CŌATĔD BǓLB, see TUNICATED BULB.

CŏB'WĔBBY̆, having fine slender filaments or hairs like cobweb; arachnoid.

cŏCÇID'ĬŬM (p]. Cŏcçĭd'ìå), a sporocarp like that of Delesseria (one of the algx), being a closed case with the spores borne on a central placenta.

CŏcÇǏF'ÈROŬS, producing berries; bacciferous.

CŏCÇĪN'

Cŏc'CǓs (pl. Cóc'çī). (1) One of the separable one-seeded carpels of certain dry fruits, as Euphor- 
bia. Compare Regura. (2) A spherical or spheroilal cell among bacteria, especially of the gemus Micrococcus.

Cŏ€H'LĖ̇, see Strombus.

CŏEH'LĖA, a form of æstivation in which one piece being larger covers ail the others, as ill Acouitum. Compare VexILLARY.

Cǒ€HLĒ̌̆R'ǏFôRM, shaped like the bowl of a spoou.

CŏCH'LĒĀTE, shaped like a snailshell; spirally turbinate. Practically the sime as strombuli. form.

CǒcKs'CōMBED, fasciated. Applied mainly in horticulture to strawberries which are irregular in shape from being tlattened at the sides or fasciated.

Çॅ̌L'ŌSPĚRM, a coelospermous seed.

Çడ̌EL̄SPẼR'MOǓs, applied to the seeds (cremocarps) of coriander. and some other Umbellifere, which have the inner surface hollowed by the curving iu of the top and bottom.

ÇĒNĂN'THIŬM, see CLINAX̃тніUл. Also sometimes applied to receptacles like the tig, or to any fleshy receptacle in which the Howers are more or less embelded.

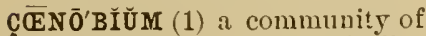
a definite number of unicellular individuals united in one bolly of definite form, as in Volvox: cenobium. Compare Cell-FAirly. (2) A name of the fruit peculiar to the Boraginacex and Labiatere, consisting of four distinct nutlets around a common st ̧̧le.

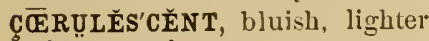
than coruleus.

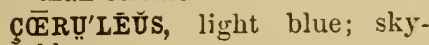
blue.

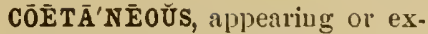
isting at the same time; of the same age.

CŌHE'RENT, having similar parts more or less united, as the petals in a gamopetalous co. rolla. Compare AdHerext.

CōHÉ'sION, the union of members of the same whorl or kind. Compare Adilesion.

Cō'HôRT, a matural group of orders within a class; alliance.

CŌLĒŌPHY̌L'LŬM, a membranous or fleshy sheath investing the plumule in Monocotyledons.

CŌLẼ̄P'TǏLE, see COLEOPIIYLLUM.

CōLĒôRH I'́ż, the covering through which the radicle of most MLonocolyledons bursts in germination; root-sheath. The term has also been applied to the vascular-buudle sheath in roots.

CóL'LAR, the line of junctiou between the stem and root; collum; neck. Also applied to the annulus of a mushroom.

CǑLLĂTẼRAL, side by side.

CǑLLĂT'ẼRAL BŬN'DLE, a fibrovascular bundle having a single strind of phloem in continuous contact witl a single strand of xylem. Compare BicoLLATERAL BUNDLE, RADIAL Buxde, and Coxcentric BUNDLE.

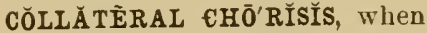
the parts originating by chorisis stand side by side; parallel chorisis. Compare TraxsVERSE CHORISIS.

CơLLĚCT'ǏNG HÂIRS, hair's upon the style in certain Composita which serve to collect the pollen as it is discharged from the anther.

CǑLLĔCT'IVE FRỤIT, a fruit- 
like body originating from more than one flower, as the mulberry; multiple fruit; pseudo-syncarp. Compare Anthocalpous Fruit, ACcessory Fruit, and AggreGATE FIRUIT.

CŎLLĔCT'ORS, see CollectiNG HA1RS.

CǑLLĚN'€HY̌M posed of cells liaviug carti!aginous thickenings at the augles. Common beneath the epidermis of stems, and in other places where strength is required.

CớL'LET, an old term for collar.

CǑLLE'TẼRS, glandular hairs which secrete a gummy matter (blastocolla) upou buds.

CǒL'L $\overline{0 I D}$, n., any substance in the colloid stite.

cơL'นÖD, adj., resembling jelly; the molecular condition of a class of substances, such as gums, usually produced by the disorganization of orgunized mitter, which mix with water in all proportious and pass from the solid to the fluid state through all stages of softening, thus differing from Crystalloids, which see.

CớlŌ̄̃'AL, see Colloid.

CŏL'LŬM, the neck or tapering base of the capsule in mosses; the line of junction between root and stem; collar.

CǑLMAR SHĀPED, pear-shaped with a rather slender neck ind large body. (J. J. Thomas.)

CŎL'ŌNY̆, see CELL-FAMILY.

COL'ÖRED, of any other color than green.

Cర̌PEN'€HY̌MA, epidermal tissue composed of cells with sinuous margins. Not in general use.

cð̌LŪMĽL'LA, the axis or central column of a porl or spore-case. Usually a placenta.

CǑLŪMĚL'LǏFÔRM, shaped like a iittle column or columella.

CǑL'ǓMN, the united flameuts and styles in a gynandrous flower, as an orchid.

CōLǓM'NAR, shaped like a columv or pillar: round or nenrly so, taperiug slightly or none, and not so loug as to be called slencler. Often applied to styles. Compare Terete.

$\mathbf{C O} \bar{O}^{\prime} \mathbf{M} \dot{A}$, a tuft of hairs on a seed; a terminal cluster of empty bracts; iny tuft.

CŌ'MĀTE, see CoMose.

CÓMBINED' HY Y'BRID, a derivative hybrid in which three or more species or varieties are united, as when a hybrid unites with a new parent form or another hybrid.

CŌMB-SHĀPED, see PECTINATE. CÓMMLN'SALİSM, see STMBIOSIs. CǑM'MÍSSŪRE, a line of junction of two parts. In the IIrattiacex a longitudinal partition connecting the two stipules and forming an anterior and a posterior chamber. Compare SUTURE.

Cǒm'MŏN, general, primary, or universal, as opposed to partial or secondary.

CŏM'MǑN BŬD, one containing botll leaves and flowcrs, or one from which more than one Hower is produced.

CX̛N'MǑN BǓN'DLE, a fibrovascular bundle a part or the whole of which passes from the stem into a lenf.

CǑM MǑN İN'VōLŪCRE, one subtending an inflorescence; general or universal involucre.

CǑM'MŌN NĀME, any name, except the "botanical name," by which a plant is known. 
CǑM'MǑN PẼDŬÑ'CLE, one supporting several perlicels.

CǑM'MǑN PĚR'ǏĂNT, applied to certain common involucres, as that surrounding the liend of flowers in Compositr.

CŎM MǑN RĒÇ̌́P'TĀCLE, one supportiug more than one Hower or other orgin.

CǑM'MŎN UัM'BĔL, see CoMPOUND UMBEL and UNIVERSAL UMBEL.

CŌ'MŌSE, bearing a coma or tuft, or growing in tufts; comate.

Со̆мPӑсT', solid; close.

CǑM'PLȦNĀTE, flattened verticilly to a level surface above and below. Applied also to several organs which are flattened or arranged so as to lie in one plane, and to such as lie flat upon or against each other, as when leaves lie flat upon the stem. Compare Explanate and CoMpressed.

CǑMPLÈTE', haviug calyx, corolla, stamens, and pistils. Compare Penfecr.

CŎM'PL $\breve{X X}$, an assemblage of interwoven fibres, or any group of complicated parts.

CǑM'PLİCĀTE, folded together forward. Compare REPL1CATE and CONDUPLICATE.

CǑM'POUND, consistiug of a number of similar subordinate parts forming a complete whole, as the leaf of the walnut.

CǑM'POUND CŏR'Y̌MB, one with more than one Hower on each ray or branch.

CǑM'POUND DIEHA'SĬUM, one in which the primary axis termiuates in a flower, beneath which arise several secondary axes, each of which terminates in like mauner, as in valerian.
CǑM'POUND FLOW'ẼR, an old ter'm for the flower-hend in Composita.

CǑM'POUND FRƯIT, see AGGREGATE FlRUTT.

CǑM'POUND IN'FLŌRĚS'CENÇE, one in which the ultimate branches each bear more than one Hower, thus forming a com. pound spike, corymb, etc.

CǑM'POUND LEAF, one having two or more distinct blades, or leatlets, as in the ash.

CǑM'POUND Ō'VẢRY, one having more than one carpel.

CǑM'POUND Pİs'TIL, one composed of more than oue carpel. CǑM'POUND RẢÇĒME', sce PANICLE.

CŏM'POUND SPIKE, one having more than owe flower or spikelet on each short branch, as wheat. Applied especially when the secondary spikes are well developed, or when, as in Panicum sunguinale, the infloresceuce consists of several spikes of nearly equal size arising from the apex of the peduncle.

CǑM'POUND SPŌRE, a spore consisting of more than one cell, each of which is frequently capable of germination. It differs from Gemma by its more definite form and specialized method of production. The synonyms are spore-group, semen-multiplex, compound spore, cellular spore, multicellular spore, pluricelhular spore, septate spore, polyspore, sporidesm, etc. See IIErrSPORE.

CǑM'POUND SPŌ RŌPHŌRE, oUe formed by the coliesion of separite hyphal branches. Compare Sruple SporoPHORE. 
CǑM'POUND STĚM, a branched siem.

CǑM'POUND ǓM'BĔL, one in which each primary ray bears a smaller unbel instead of a single flower. Formerly known as Common, General, or Universal Umbet.

CǑMPRĚSSED', flattened, especially lengthwise laterally, the horizontal diameter much less than the vertical. Compare DEPRESSED, OBCOMPRESSED, and COMPLANATE.

CǑNCĂT'ẼNĀTE, joined in a continuous series like a chain; catenate; catenulate.

CŎNCĂ T'ĒNĀTĚD, see CONCATENATE.

CŎNCẠULĔS'ÇENÇE, the COAescence of the pedicel of a flower with the stem for some distance above the subtending bract.

CŎNÇĚN'TRǏC, having a common centre.

CǑNÇĚN'TRĬC BŬN'DLE, a fibrovisculat bundle in which a strand of one element is wholly surrounded by the other, as in some ferms in which the xylem is wholly surromuled by phloem.

CǑNÇĚP'TA்CLE, a name applied to sac-like receptacles of various kinds, as perithecium, cystocarp, follicle.

CŎNÇ̌PTĂC'ŪLŬM, see CoNCEPTACLE.

CON€H'IFÔRM, like half a clamshell.

CǒN'COLǑR, of the same color as another part or plant. Also applied to several objects which are all of the same color. Compare Uxicolor.

cón'COLǑRED, see CONCOLOR. CŏN'CŏLŏROǓs, see CoNCOLOR.
CŏNCŏM'ÍTANT, applied by De Bary to tibrovascular buudles which run continuously sicie by side without becoming separated by other bundles.

CǑNCRĔS'ÇENÇE, see CEMENTATION.

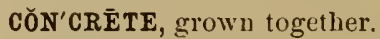

CŏNDŬCT'ǏNG ÇĚLLS, narrow elougated cells associated with sieve tubes, and similar to them, but without perforated walls.

CŎNDǓCT'ǏNG TǏS'SŪE, tissue composed of conducting cells. Compare Conductive 'Tissue.

CǑNDUัCT'ǏVE TǏs'SŪE, that through which the pollen tube passes on its way to the ovary. It is often loose in texture and moist with nutritive fluid for the growth of the pollen tube.

CǑNDÜ'PLICCĀTE, folded together forwirl and leugthwise in any manner: complicate. Compare Replicate and INFLEXED.

CōNE, the fruit of Coniferæ; strobile: also applied in other plants to a fruit or inflorescence resembling the cone of the fir or pine. See Gar.bunus. CǑNFẼRRỰ'MǏNĀTE, closely united, as the cotyledons of the horse-chestnut.

CǑNEẼR'TĚD, crowled or clustered; opposed to distinct. Compare CoNGEsted.

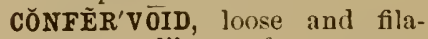
mentose, like confervil among algæ.

CǑN'FLŪENT, ruuuing together or blended into one; coherent.

CǑN'FLÜEN T FRƯIT, an old term for collective fruit.

CóNFôRMED', (1) closely resembling; (2) closely fitted to, as the skin to a seed. 
CǑN'GENẼR, a plant of the same genus as another.

CǑNGENĔR'ǏC, said of two species or individuals which belong to the same genus.

CǒNǴ' $\overline{\mathbf{E}}^{\prime} \mathbf{R I} \overline{\mathbf{E}} S$, a collection of parts or organs. (Rare.)

CǒNǴĚST'ĚD, packed closely together.

CǑNGLŌ'BĀTE, clustered into a ball.

CǑNGLŎM'ẼRĀTE, clustered together; opposed to Diffuse.

CǑNGL $\bar{U}^{\prime} T$ ǏNĀTE, glued together in a mass.

CǑN'ǏCAL, in the form of a geo. metric cone. Said of a root when it tapers downward, or of any other part when it tapers upward or outward. Compare OBCONICAL.

CōNÍD'İ, pl., see CoNIDIUM.

CŌNǏDǏÍF'ẼROǓs, learing coniclic.

CōNǏD'ǏŌPHŌRE, a branch of mycelium bearing one or more conidia.

CōNǏD'ǏŌSPŌRE, see CoxıDIUM.

CŌNǏD'ǏŬM (pl. Cōnĩd'íà), :ı asexual spore (goniclimm) alsstricted singly or otherwise from the apex of a filament, as in Peronosporil. Applied chiefly where the spores form a dusty or powdery coat, but not userl in Hymenomycetes, aud in less use elsewhere than formerly, the general term Gonidium being now usually employed insteid.

CŌNǏE'ÈROǓs, cone-bearing.

CŌN'ǏFÔRM, see CONICAL.

Cō'NǏōçY̌sT, a term applied by Harvey to the oogonium of Vaucheriex.

CǑN'JŪGĀTE, joined or arranged in pairs, as the leatlets of many compound leaves; paired. Sec BINATE.

CǑNJUGG $\bar{A}^{\prime}$ TION, the simplest method of fertilization, in which the male and female cells are alike or nearly so, as in the order Conjugatex; $z y$ gosis. The uniting cells are called gametes and the product a zygote. The conjugation of naked protoplasmic bodies, as zoospores, is sometimes called Coalescence.

CǑNJŪGA'TION-ÇĚLL, see GANETE.

CŎNJǓNC'TǏVE THRĔADS, Fol's ternı for spindle-fibres, which see.

CǑNNĂS'ÇENT, produced at the sime time.

CǑN'NĀTE, said of organs of the same nature which are grown together from the first or united at the base. Compare $\mathrm{AD}$ NATE.

CŎN'NĀTE-PẼRFō'LĪĀTE, Saiil of a pair of opposite leaves when their buses are united around the stem.

CŎNNĚCT'ǏNG CĚLL, Harrey's term for Heterocyst, which see.

CǑNNĔCT ǏvE, the part of the anther (being a continuation of the filament) which convects its two lobes.

CǑNNĔCTI' $\bar{I}^{\prime} V$ UัM, see CONNECTIVE.

CǑNNI'VENT, converging. CǑNNÜ'BĬŬM, a term applied by Pringsheim to that stage in the conjugation of Conjugater in which the protoplasm of the conjugating cells has coalesced.

Cō'NOID, cone-like; conical.

CŌNOID'AL, somewliat conoid.

CǑNSǑL'ĪDĀTĚD, (1) grown to- 
gether, said either of like or unlike parts; (2) haviug a small surface in proportion to bulk, as many cacti.

CǒN'SôRTǏsM, see SrubIosıs.

CǑN'STANT, always present, or always in the same coudition; uniform

CŏNSTRĬCT' L̆D, narrowed in certain places.

CŎNSTRŬCTĬVE MẼTĂB'ŌLISM, sce Assinillation.

CŎNTÄBĔS'ÇENÇE, the condition of being wasted away or aborted; said of anthers which contain little or no fertile pollen.

CŎNTA'ÁGIOǓs, said of diseases which are communicable from one plant or animal to anotlier by contact only, or by the direct transfer of the diseaseproduciug organism. Strict contagion implies parasitism, the orgauism being unable to grow outsicle the supporting body. Compare Infectious.

CǑNTẼR'MǏNOǓs, of equal extent.

CǑNTĬG'ŪoǓs, near, or in coutact.

CǑNTÍN'ŪOǓs, uniform in structure or outline; uninterrupted. Said of hyphæ which are without septa, or of objects which are in all parts of the same size, or whose diameter increases or diminishes regularly.

CŏNTôRT'ĚD, in restivation, when the margins of the floral leaves successively overlap each other (obliquely or otherwise) in one direction; $t w$ isted. Compare Convolute.

CǑNTÔRT'ĚD ÆૅSTǏVÄ'TION, sce above.

CǑNTÔR'TION, an abnormal twisting of branches or other organs.
CǑNTÔTTŨ'PLICÃTE, twisted and folded.

CǑNTRĂCT'ĚD, narrowed, or the successive parts shortened. Compare CoNstricted.

CǑNTRĂCT'ǏLE VĂC'ŪŌLEȘ, small cavities containing a watery fluid which malse their appearance in the protoplasm of many zoospores and other motile organisms and then suddenly disappear; pulsating vacuoles. Their fuuction is not known.

CǑNTRĂCTǏL'ǏTÝ, a property of protoplasm by which it is enabled to change its form spontaveously, or by virtue of forces within itself. Compatre IRISITABILITy.

CŎN'TRẢRY̆, extending in an opposite direction to something witl which it is compared; as, the pod of sliepherd's purse is flattened contrary to the partition.

Cō'NŬS, see CoNE.

CŏN'vōLŪTE, rolled together leugthwise from one edge, as the leaves of the plum in the bud. The term Contorted (userl mainly in restivation) refers more especially to the relation of the organs to each other and to the axis, while C'onvoluted (used mainly in veruation) refer's more to the manner of folding of the orgatu itself. A contorted corolla may or may not have its parts con. voluted.

CǑN'VŌLÜTĔD, see CONYOLUTE. CǑP'RŌPHȲTE, see SAPROPHY'TE. CŏR'ÁCOID, shaped like a crow's beak.

CŏR'ĂLLǏNE, resembling coral; corallifor'u; coralloid.

CôR'ClE, see Corculuar. CôR'CŪLŬM, an old term for 
plumule, or plumule and radicle together.

CÔR'DĀTE, heart-shaped, as usually pictured, with the point of attachment at the broad end. Applied mainly to leaves.

CÔR'DATĚD, see CoRDATE.

CÔR'DĀTE-HĂS'TĀTE, intermediate in form between corlate and hastate, approaching more nearly to hastate.

CÔR'DĀTE-Ō'VĀTE, between cordite and ovate, approaching more nearly to ovate.

CôR'DĀTE - SĂǴ'İTTĀTE, between corlate and sagittate, approaching more nearly to Singittate.

CÔR'DIFôRM, sometines applied to solid bodies shaped like the buman heart. Compare CorDATE.

CōRE, the bony endocarp of a pome containing the seeds.

CōRİ $\bar{A}^{\prime} C$ EOǓs, leathery in texture.

côRK, tissue composed of firm elastic cells, generally soon tilled with air, which are produced in the bark and upon injured surfaces. It is composed of a molitication of cellulose called Suberin, and is designed for protection.

CôRK-CĂM'BǏŬM, see PhelloGEN.

CÔRK-MĚR'ǏSTĚM, see PhelloGEN.

CÔRK'Y̌ ĽN'VĔLÖPE, see CoRKY LAYER.

CôRKY LĀY'ẼR, the layer of bark immediately below the epidermis which produces the cork; epiphløum. Compare MesophleEvi.

CôRM, the enlarged base of an lierbaceous stem, consisting of one or a few short internodes. and serving for the storage of starch or other reserve foodmaterials; pseudo-bulb; solid bulb; bulbo-tuber. It difters from a Tuber mainly iu being upright, or more nearly so, and in seldom being produced upon an elongated subterianean stem. The Indian turnip and crocus are examples. Compate Plateau.

CôR'MǓs, see CoRMr.

CÔR'MŌPHY̌TE, a plant having a true stem. Compare 'ThaisoPHYTE.

CôR'NĒoǓs, having the texture of horn.

CǑRNIC' ŪLĀTE, liaving a process or appendage like a little spur or horn. Compare ConNute. CÔR'NǏFôRM, horn-slaped.

côR NŪ (pl. Cŏr'nūà), see HorN.

CÔR'NŪTE, horn-shaped, as the nectary of columbine, or bearing a horn-sbaped process; corniform. Compare CornicuLATE.

CǒR'ǑL (obs.), see Corolla.

CŏRŏL'LA, the conspicuous part of most flowers, being the inner set of thoral envelopes when there is more than one, commonly distinguished by its fine texture and by having some other color than green. See Petal, Calyx, and PeriANTH.

CǑRǑLLÄ'ÇEOŬS, like a corolla in appearance or texture; petaloid. Petaloid is the term usually employed, especially when referring to individual organs.

CŎR ŎLLĀTE, having a corolla.

CŎR'OLLLĀTĚD, see CoROLLATE. CŎR'ŎLLĔT, see FLoRE'T.

CōRŏLLǏFLó' RAL, having ealyx, petals, and ovary inserted separately on the receptacle and 
the stamens inserted upon the corolla. Compare CalycifloRAL and THALAMIFLORAL.

CŎR'ŎLLİNE, see COROLLACEOUS. CǑR'ǑLLŪLE, see FLORET.

CŌRŌ'NA் (pl. Cōrōnæ), see CROWN.

CŎR'ŌNĀTE, having a coroua or crown.

cōRŏN'ǏFôRM, having the form of a coloua or crown.

CōRō'NŪLÀ (pl. Cōrō'nūlæ), see CoRonule.

CǑR'ŌNÜLE, a diminutive corona Ol crown.

CôR'PǓSÇLE, (1) any very sinall body; (2) see Corpusculum (in the first sense).

CŎRPŬS'CŨLȦ, pl., see CoRPÚsCLLCM.

CŎRPŬS'CÜLE, see CORPU'SCULCM.

CǑRPǓS'CŪLAR, pertaining to or composed of corpuscles or small particles.

CǑRPŬS'CŪLŬM (pl. Cŏrpŭs'cūlả), (1) an old term for the central cell in the archegonium of Gymnosperms: sometimes applied to the whole archegonium; (2) the counecting body between the arms (retinacula) which bear the pollinia of milkweeds (Asclepias).

CÔR'RỤGĀTĚD, iu folds or wrinkles.

CôR TĚX, that portion of the fundamental tissue lying outside the tibrovascular bundles. In trees it is the "outer bark."

CôR'TÍCAL, pertainingr to the bark or cortex.

CÔR'TǏCAL SHĒ ATH, the riug of primary bast (phloem) bundles. Compare Medulatir Sheath. CôR'Tİ́ĀTE, having a rind or cortex.

CôRTǏCǏF' ẼROǓs, prod $u \mathrm{c}$ in g bark or cortex.
CǒRTỊ̌̆'ǏFôRM, like bark.

CóRTĬC'ŌLOǓs, growing upon the bark of trees, as many mosses and lichens.

CôR'TǏCōSE, having or resembling bark; corticous.

CÔR'TǏCOǓs, see CoRTICOSE.

CôRTI'NA, the remnant of the veil sometimes found at the borrler of the pileus or cap in mushrooms.

CǒR'Y̌MB, a convex or flat-topped indefinite or centripetal intlorescence, like a raceme with the lower pedicels elongated. Compare Crus.

CŌRY̌M'BĀTE, having corymbs, or growing in corymbs.

CǑRY̌MBǏF' ẼROŬS, prolucing corrmbs.

CōRY̌M'BŌSE, growing in or resembling corymbs; corymbous.

CŌRY̌M'BOŬS, see CORYMBOsE.

CŌRY̌M'BÜLŌSE, arranged in small corymbs.

CŌRY̆M BŬS, see CoIYMB.

cŏȘMóP'ŌLITTE, a plant widely extended in the world, as Pte$r$ is aquilinu.

CŏS'TÁ (pl. Cós'tæ), see Riв.

Cŏs'TAL, pertaining to a rib.

CǑS'TAL-NẼRVED, a term sometimes applied to parallel-veined leaves when the veins arise from a midrib and run toward the margins, as in the banana.

Cǒs'TĀTE, having one or more prominent veins or ribs.

CŎSTĔL'LĀTE, having small rilos. CŎTY̆LE'DǑN, the first leaf or leaves of a plant: seminal-leaf; seed-lobe; seed-leaf. In exogens they are usually different in form from the leaves produced afterward, and are stored with nutritive matter for the young plaut. 
CǑTY̌LĚD ǑNOǓs, haviug cotyledons.

CŌTY̌L'ǏFôRM, like a cotyle, the articulating cavity of a bone; a little shallower than acetabuliform.

COWLED, see CCCullate.

CRĂM'PǑN, see HoLD-FAsT.

CRAंTẼR'ǏFôRM, goblet-shaped: narrower tlan Calathiform and less flaring than Cyathiform.

CREEP'ǏNG, rumning upon or under ground and rootiug; re. pent.

CRĔMǑCÄRP, the fruit of Lmbelliferze. Also applied to other fruits of somewlint similar structure, as that of maple. See Mericarp and SchizoCARP.

CRE'́n'́, see CRENature.

CRE'NATE, having the margin furnished wilh rounded teeth, which usually point toward the apex of the object bearing them: crenated; crenelated: crenelled. See Doubir, Acetely, and Obtesely C'renate.

CRE' NĀTĚD, see CRENATE.

CRĚN'ÁTŨR, a tootl of a crenate malrgiu; creuel; creua.

CRENĚL', see CRENATCRE.

CRĚN'ĚLĀTĚD, see CRExATE.

CRENĚLED', see CRENATE.

CRẼNELLED', see CIENATE.

CRĚN'ŪLĀTE, diminutive of creuate; laving the margin furnished with fine rounded teeth.

CRĚN'ŪLĀTĚD, see CRENULATE.

CRĔST, (1) a partial aril in the form of a ridge aloug the raphe of some seeds, as Singuinaria aud Dicentra. Compare AliL, STRophiole, and Caruncle. (2) An elevated ridge or appendige termiuating any organ: a stimen is crested when the filament (comnective) projects beyond the anther.

CRĚST'ĚD, having a ridge ol termiual appeudage; cristate.

CRETT $\bar{A}^{\prime}$ CSEOÚS, (1) of the color of chalk; (2) growing on chalky land.

CRǏB'RĀTE, see Cribrose.

CRǏB'RIFF̂RM, see CRIBROsE.

CRĬB'RǏFôRM ÇĚLLS, see SIETETUBES.

CRǏB'RŌSE, pierced with small holes like a sieve; cribriform; cribrate.

CRİB'RŌSE ÇĚLLS, see SIEVETUBES.

CRI'N $\bar{I}^{\prime} T E$, having a tuft or fringe of long weak liairs.

CRI'NOID, resembling a lily.

CRISP, having the surface, especially near the malgin, strougly and finely mudulate, as the leaves of Sivoy cabbage or the cultivated endive; curled; crispate; crisped.

CRǏS'PĀTE, see CRISP.

CRǏSPED, see CRIsP.

CRĬS'TĀTE, see C'IESTED.

CRǏS'TĀTĚD, see CIRESTED.

CRǏT'ǏCAL, difficult to chiracterize or classify.

CRŏss, a uniou of two varieties of the same species. Applied in a narower sense to the offspring of auy two flowers which have been cross-fertilizerl. Compare Hrbind.

CRǑSS-ÄRMED, see BRACHIATE.

CRǑSS-BREED, see Cross.

CRǑSS-FẼRTǏLǏZ $\bar{A}^{\prime}$ TION, the fertilization of a Hower by pollen from another flower, especially from one of auother variety of the same species; allogamy. Compare Close-fertilizaTION. 
CRŎSS-PŎLLǏNĀTION, the conveyance of pollen to the stigma of another flower.

CROWN, (1) an appendage in the throat of the corolla in some Howers, as Silene aud Narcissus; coroua; paracorolla. In some cases it represents a circle of metamorpliosed stamens.

(2) A ring of cells at the apex of the nucule in Characere. (3) Any circle of organs in the form of a crown, as the scales at the apex of an achene.

CROWN'ING, borne at the apex.

CRŌZIẼR, auything witl a coiled end, as the young leaves of most ferus.

CRU'CYIATE, in the form of a Mialtese cross, as the petils of Cruciferæ; cruciform; clossshaped.

CRỤÇǏF'ẼROǓs, (1) belongiug to the Crucifere or musturd family; (2) resembling plants of the mustard family, especially in the form of the Hower.

CRƯ'ÇǏFÔRM, see CRLCiATE.

CRŬMPLED 臭STǏVA'TION, when the petals are irregularly folded in the bud, as in the poppy.

CRU'RAL, somewhat leg-sliaped. Used mainly in composition.

CRŬSTÁ'ÇEOŬS, said of the thallus of it lichen when it forms an adherent crust which cannot be removed from the substratum without injury.

CRY̌P'TŌGĂM, a plant belonging to the lowest of the two clice divisions of the regetable kingdom, including ferus, mosses, fungi, etc. Cryptogams produce no true seeds or flowers, but in most groups there is a process of fertilization essentially the same as in the higher plants.
CRȲPTŎG'ẢMOǓs, pertaining t? cryptoganis, or plants haviug no true flowers or seeds.

CRY̌P'TŌPHȲTE, see CRYPTO. GAII.

CRYัS'TALLOIDS, protein bodies in the form of crystals; allumen crystals. Applied also in opposition to Colloids to indicate all substances susceptible of crystallization and of diffusion through a membrane. (Graham.)

CŨ'CǓLLĀTE, conical, witlı the sille cleft, and often inrolled like a cornet of paper, as the spathe of arum and the calyptril of some mosses: cuculiforns; lıoded; hool-shaped; cowled.

CÛCŬL'LǏFôRM, see C'CCULLATE. CŪCUัL'LǓs (pl. Cūcǔl'lì), a term sometimes given to various hood-shaperl organs, especially a concave and arched sepal or petal, as the large upper sepal (galea) of A conitum.

CŨCƯ'MǏFôRM, having the form of a cucumber.

CŪCÛRBǏTA'ÇEOǓS, belonging to or resembling plants of the Cucurbitacex or melon family. CƯL-DĔ-SĂC, a tubular or banshaped cavity closed at one end.

CŬLM, the stem of grissses; sometimes applied to that of sedges also.

CǓLMǏC'ŌLOǓS, growing upou the stems of grasses, as certain fungi.

CŬLMĬF'ẼROǓS, p r.o d u c i n g culns.

CŬL'TRĀTE, shaped like a pruning-knife; broad, thin, pointed, with the end curved edgewise; cultriform.

CǓL'TRĀTĚD, see CuLtratTE. 
CǓL'TRǏFôRM, see CuLTRATE. CU'NEAL, SEC CUNEAT'E.

CU' $\bar{U}^{\prime} \mathbf{E} \bar{A} T E$, wedge-shaped in outline. Said of leaves which are broand above and narrowed to the base in straight lines. The same as Obdeltoid but usually narrower; cuneiform.

CŨNE'IFÔRM, see CUNEATE.

CÜNIC'ŪLĀTE, piercell with a long narrow passage or passilges.

CǓP, (1) a concave involucre enclosing a nut, as in the acorn; cupule; (2) a discocalp (apothecium) in Ascomycetes.

CŬP-SHĀPED, a rather indefinite term, lisually applied to cavities from one half to twice as deep as broad, with concave bottom and nearly vertical sicles

CŨ'PŪLÁ, ste CUP.

CU'́U'PUATE, furnished with a cup or cupule.

CŨ'PÜLE, sce C'UP.

CŪPŪLIF' ĖROǓS, bearing or furnished with a cupule or cupules.

CƯ'PÜLIFôRM, see CUP-SIAPED. CÛRD, applied in horticulture to the material composing the head in calulitlower. Sometimes the heads iudividually are called "curds."

CÛRLED, see CRISP.

CÛRVĬCẠU'DĀTE, Laving a curved tail.

CÛRVǏCŏs'TĀTE, baving curved ribs or linge veius.

CÛRVİDẼN'T̄ ÁTE, having curved teeth.

CÛR'VIFF̂rR, curved.

CÛR'VǏNẼRVED, having curved nerves. Applied to the veins (so-called nerves) of enclogens.

CÛRVǏsE'RİAL, in curved rauks. Compare Rectiserial.
CUSH'ION, a thickened medial portion of the prothallus in terus; any pulvinus.

CǓSP, a sharp rigid point.

CŬSPED, see CUSPIDATE.

CŬS'PĬDĀTE, furnished with a cusp.

CŬS'PǏs, see CusP.

CǓT, acutely cleft or parted; having acute incisions deeper than Dentate. CompareCLEFT, INCISED, and LACINIATE.

CÜ'TICLE, the outer cell-wall of the epidermis when thickened or otherwise molified.

CŨTĨCŨLÄRǏZA'TION, the formation of cuticle.

CU'TIN, sec SUBERIN.

CU'T'TIS, SEe CUTICLE.

CUTTINIIZA'TION, the formation of cuticle. Compare SuberIZATION.

CǓT-T00THED, deeply and suarply toothed.

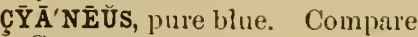
Caruleus.

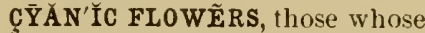
color contains mole or less blue. Compare Xantur Flowers.

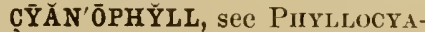
NIN.

ÇỸ ĂTH'ǏFôRM, wine - glass shaped. Compare CotruiFORM and ACETABLLIFORM.

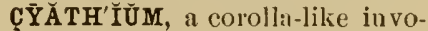
lucre, as in Euplıorbia.

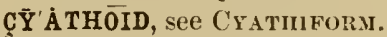

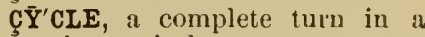
spire or circle.

ÇY̌C' I ĬC, having the floral organs in distiuct whorls. Compare Hemictelic and ACrCLIC.

ÇY̌C'LǏCAL, coiled into a full circle.

Ç̄̄YLo'sÍs, sce Rotation. 
GȲCLŌSPẼR'MOǓs, having the embryo coiled around the ceutral albumen, as in the Caryophyllacese.

CYYLǏNDRĀ'ÇEOǓS, nearly cylinilical.

ÇY̌L̆N'DRĬCAL, circular in transverse ontline and tapering but little if at all, as most stemis.

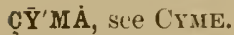

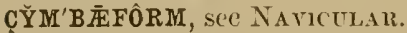
ÇY̌M'BĬFÔRM, see NAVICULAR.

ÇȲME, a somewhat flat-topped leterminate inflorescence resembling a corymb.

ÇȲME'LĚT, see CrMLI.E.

ÇȲMǏF'ẼROǓS, prolucing cymes. CYYMÖ-BǑT'RY̆S, a mixed inflorescence in which the primary inflorescence is botryose while the secondary is cymose, as in the horse-chestnut.

ÇY'MOID, llaving the form of a cyme.

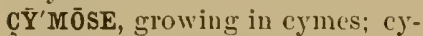
mous; or cymoid.

CYY'MŌSE ǏNFLŌRĚS'C̣ENCE, a cyme or other determiuate inflorescence.

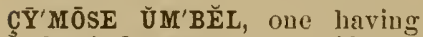
the inflorescence centrifugal; a cyme resembling an umbel. Unbels are usually botryose (centripetal) in intloresceuce.

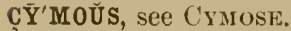

CY̌M'ŪLA, see CYMULE.

Ç̄'M $\bar{Y}^{\prime} \mathbf{U} L E$, a little cyme, or division of a compound cyme. Sotactimes applied to the verticillasters of Labiatæ.

ÇY̌NĂRRHŌ'DǏŬM, a fruit-like body, like the lip of roses, consisting of several acheuia enclosed in a flesliy receptacle.

ÇY̌NĂR'RHŎDŎN, sce CYNALRIIODIUM.

ÇY̌PẼRA'CCEOǓS, resembling or pertaining to plants of the fam. ily C'yperaceze.

ÇȲPHĚL'LA (pl. Cyphĕl'1æ), a kiud of pit in the under-surface of the thallus of some licheus. C'sphella sometimes appenr as spots or as eleviltions. 'Their nature is unknown.

ÇȲPHĚL'LĀTE, having Cyphellix.

CYYP'SĚLȦ, an achenium with an adherent caly $x$-tube, as in Compositie. (Obs.)

ÇY̌sT, a closed sac, especially one abnormally produced, or whose nature is not understood.

ÇY̌S'TǏD (pl. Cystǐds or Cys'tĭdēs), a large sterile ('hul)-shaped cell common among the basidia in some agarics.

ÇY̌STǏD'ǏŬM (pl, Çstǐd'ía), sce Crstid.

ÇY̌S'TŌBLȦST (obs.), sce NuCLEUS.

ÇY̌s'TŌCÄRP, an old term for the Sporocarp of Floriciex.

ÇY̌S'TŌLİTH, a cluster of crystals of calcium carbonate in a cell upon a stalk of cellulose. Common in the leaves of the nettle family (Urticacea).

CYYTĂS'TẼR, a series of achromatic rays extending from each pole of the nucleus in karyolinesis into the cytoplasm. Rarely seen as yet in plants.

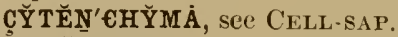

ÇỸT'ĪODẼRM, the cell-wall in Diatomacer.

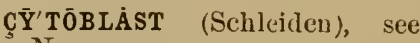
NUCLEUS.

ÇỸTŌDİER' $\bar{E} S \check{S}$, cell-division, involving division of the nucleus with the formation of a nu- 
clear-spindle and asters. (Carnoy.) Compare Stexosis.

ÇỸTŌGÉEN'ẼSISS, cell-formution. ÇȲTOLL'ŌGY̌, the science of cells.

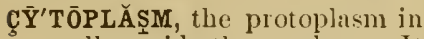
a cell outside the nuclens. It excludes grauules of protein, stareh, ete. Compare Nucleo. I'LASI.

JÄRWǏN'İAN CÛR'VĀTURE, the curvature of the growing apex of a root a way from any source of irritation placed upon one side near the tip. It is the irritability which cituses this curvature that enables growing roots to pass around ol)stacles in the soil.

DA्UGH'TẼR-ÇELL, any cell when mentioued in relation to the one from which it wis derived. Compare MotTHER-CELL.

DẠUGH'TẼR-SPŌRE, a spore pro"luced directly from another, or upon a proinycelium.

DAUGH'TẼR-STÄR, one of the groups of chromatic tilaments at the poles of a dividing uucleus. The two polar figures together with the connecting spindle-tibres are called a Dyaster.

DË ÁL'BĀTE, appeariug as if whitewashed: covered with a very white bloom or pow (ler.

DĚCĂGY̌Y'ǏAN, see DECAGY Not's.

DĒCĂG'Y̌NOǓS, haring teu pistils or styles: decagyniau.

DĒCĂM'ẼRoǓS, Laving the parts in tens, as ten floral organs in a whorl. Also writteu 10 . merous.

DËCĂN'DRĬAN, see DECANDROUS.

DĒCĂN'DROǓs, having ten stamens; decaudrian.
DĔCẢPĚT'ALOǓS, having ten petals.

DĔCA்PHY̌L'LOǓS, having ten leaves, as a decaphyllous periauth.

DĒCQĔMDĚN'TĀTE, having ten teeth or tooth-like processes.

DĒČEM'FÍD, teu-cleft.

DËĔMLǑC'ŪLAR, lıaving ten loeuli or cells in an ovary.

DĒÇİ'ŨoǓs, falling at the usual time, or at the close of the scason. Applied to leaves which fall in autumn after one season's growth, und to plants which bear such leaves. Also applied to petils which fall immerliately after blossoming. Compare Caducous, Marcescentr, Peristext, and EVERGIEEN.

DĔC'LINA ĀTE, bent or culved downward: deelining; declined. Applied to stamens it means curved to one side, neitler outward nor inward nor erect. Compare liecrrived, Reflexed, Reclinate.

DĒCLINED', see DECLINATE.

DẼCLI'NOǓS, see DECLINATE.

DĒCŏMPOUND', twice compound, as a compound leaf whose parts are compound. See SUPRADECOMPOUND.

DĒCRĒAS'ǏNGLY̌ - PIN'NĀTE, having the leatlets of a piunate leaf gradually smaller iu size from base to apex.

DÉCUMBENT, erect at the base, then prostrate, with the end rising.

DËCǓR'RENT, prolonged and attacherl below the main point of insertion, as the leaves of thistles; decursive. The stems in such cases are often called IVinged. Compare SurcurRENT.

DËCÛR'SĬVE, see DECURREN'T. 
DĒCÛR'SǏVELY̌-PǏN'NĀTE, appareutly pinnate, but having the segments decurrent along the rachis.

DẼCUัS'SĂTE, said of leaves which grow in pairs successively at right angles to each other. Compare Brachite.

DĒCǓS'SĀTĔD, sec DEcUSsATE.

DEDOUBLEMENT [Day-doobi-imän], see CHonisis.

DĒDŨPLICA'TION, see CHorisis.

DĚF'ẼRENT, currying auything dowuwards.

DĚF'ǏNǏTE, (1) lıaving a constaut, fixed, or limited, num ber; in stamens not exceeding twenty; (2) the same as Determinate, which see.

DĚF'ǏNITTE GRŌWTH, see DETERMIXATE GROWTH.

DĚF'ǏNǏTE INNFLŌRĚS'ÇENÇE, See DETERMINATE INFLORESCENCE.

DĒFLĔCT'ĚD, sec DEFLExed.

DËFLĔXED', bent abruptly to one sicle or outwarl at an angle of forts-tive degrees or less; detlected. Compare REFRACTED and Recurved.

DËFLO' RĀTE, past the flowering state, as an anther after it has shed its pollen, or a plant or Hower after the petals have falleu.

DÉE $\bar{O}^{\prime} L \bar{I} \bar{A} T E$, having cast its leaves.

DĒFŌLI $\bar{A}^{\prime} T I O N$, the fall of leaves.

DEFF ĈRM $\bar{A}^{\prime} T I O N$, an alteration in the usilal form of an organ, by accident $\mathrm{Ol}^{\circ}$ otherwise; malformation.

DËGĚNĚRA' $\bar{A}^{\prime} T I O N$, deficiency in size or quality, or appeariug in a less developed or lower state, as when scales take the place of leaves, or petals the place of stameus; degradation.
DĚGRẢDÁ TION, sce DEGENERATION.

DĒHǏSCE', to open for the escape of seeds, spores, etc.

DËHǏSÇENÇE, the opening in a regular manuer of certain fruits to discharge their seeds, aud of anther's and spore cases to discharge their contents.

DĒHĬS'ÇEN T, opening in il regular manner to discharge the contents, as most poils to liberate the seels. Compare INDEHISCENT.

DĒLİMITTÁTION, see ABJUNCTION.

DĚLǏQUĚS'ÇENT, lissolving. Said of a tree which branches repeatedly, so that the main stem is lost. Compare ExcurRENT. Also applied to fungi which dissolve at maturity by the absorption of moisture from the air, as some mushrooms.

DĚL'TOID, nearly in the shape of an equilateral triangle, or the Greek letter delta. When applied to leaves it implies that the attachment is at the broad end, olherwise the term $\mathrm{Ob}$ deltoid is used.

DE $\bar{E}$ ẼRSED', growing constantly or naturally under water; immersed; submersed.

DĚN'DRǏFôRM, tree-shaped.

DÉNDRĬT'ÍC, branched like a tree; dendriform.

DEN'DROID, tree-sbaped; dendriform; dendritic; arborescent; applied to small plauts, such as mosses, which branch like a tree or shrub.

DĚNDROL'ŌGY̆, the natural history of trees.

DËN'ÍGRĀTE, dark dusky brown. DENSE, crowded together.

DĚN'TĀTE, having broad acute 
marginal teetl which are usually directed outward. Conpare SERRATE and CRENATE.

DĚN'TĀTĚD, see DENTATE.

DĚN'TĀTE-ÇIL' ǏATE, haviug the margin dentate and fringed.

DĚN'T $\bar{A} T E-C R \bar{E}^{\prime}$ NĀTE, (1) having part of the margin dentate and the remainder crenate; (2) intermediate between dentate and crenate, i.e., having somewhat rounded teeth.

DĚN'TĀTE-LĀCYIN' $N^{\prime}$ İTE, having the teetl extended into long lax points.

DĚN'TĀTE-SĚR'RĀTE, (1) intermediate between dentate and serrate; having the teelh directed but slightly forward: (2) having part of the margin dentate and the remainder sellate.

DĚN'TĀTE-ŠL' ${ }^{\prime} \bar{U} \bar{A} T E$, liaving broal shallow simuses between the teeth of a dentate margin.

DĚNTĀTǑ-SĚR'RĀTE, see DENTATE-SEIRRATE.

DĚNTĀTŎ-S̆N'ŪĀTE, see DENTATE-SINUATE.

DËN'TICLE, a small tooth or projecting point.

DĚNTǏC'ŨLĀTE, having small teeth or notches; finely dentate.

DẼNTICŪLA'TION, (1) the state of being denticulate; toothed; (2) one of the teeth of a denticulate leaf.

DEN'TIFFôR, see DENTOID.

DEN'TOID, tooth-shaped.

DEENÜDĀTE, deprived of the usual corering, especially of a coating of down or hair. The term has been applied with little reason to plants whose Howers appear before their leaves.

DĒŌPẼR'CŪLĀTE, applied to moss capsules in which the lid does not separate spontaneously to liberate the spores. Compare Disoperculate.

DẼPẠU'PẼRĀTE, sail of a plant or part of a plant which is rednced in size from lack of nutrinent, or apparently so; starved; stunted; undeveloped.

DËPĚND', to hang directly downward.

DĚP'LA்ĀTE, Hattened vertically aud expanded. Both sides may be flattened (Complimate) or only the upper. (liare.) See Explanate, Depressed, and CUIPLANATE.

DËPRĚSSED', more or less flattened vertically or endwise; oblate. Also applied to any part having a lower position than usual, as a leaf whose disk is lower than the margin, as in some water lilies.

DĒPRĚSSED'-GLŌ'BŌSE, globular with the poles slightly flattened; oblately spheroidal.

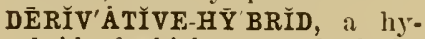
brid of which one or both the pareuts is a liybrid; secondary hybrid.

DẼRMĂT'ŌGEN, the primordial epiclermis, i.e., the epidermis in an organ when first former and still capable of cell-division.

DẼRMĂT'ŌPHȲTE, any fungus parasitic upon tle skin of man or other animals, as T'richophy. ton tonsurans, the fungus which causes ringworm.

DËSÇĚND'ǏNG, directed downward in any degree.

DĒSÇEND'ǏNG ǍX'Ǐs, root.

DĒSČ̌ND'ǏNG MĔTĂMÔR'PHŌSİS, see Retrogressive METAMORPHOSIS.

DËSÇĚND'ǏNG SĂP, a term formerly applied to cambium 
when in a soft mucilaginous condition, from the supposition that the sap passed in a corrent upward in the wood to the leives, then downward between the wood and bark. See Propen Juice.

DËSCRǏP'TIYVE BǑT'ÁNY̌, see PHYTOFRAPIIY.

DĒSTRŬC'TǏVE MĒTĂB'ŌLǏSM, the chemical changes which take place during the waste of tissues. Compare Assminta. TION.

DĒSTRỮC'TÍVE PĂR'ÁSİTE, ONe which causes the death of the tissues of the host upon which it feeds.

DẼTẼR'MǏNĀTE GRŌWTH, when the season's growth ends in a well-formed bud.

DĒTẼR'MǏNĀTE ÍNFLŌRĚS'CENCE, one in which the flowering begins with a terminal bud so that it puts a limit to the elongation of the stem; centrifugal or definite inflorescence.

DẼTẼRMÍNÁtTION, the discovery of the botanical name of a plant, or of its position in a system if nunamed; identification. It implies some knowledge of its characters acquired by at more or less complete analysis, and is frecquently completed by the aid of a systematic key.

DEU'TŌPLĂȘM, the portion of the cell contents aside from the protoplism proper, consisting of cell-sap in which may be granules or other substauces; paraplasm. Compare Metaplasm.

DĚX'TRÔRSE, twining npward from left to right, with the suu or hands of a watch, as the hop. Used in the opposite sense, however, by most Eng- lish and American botanists. Compare Sinistrose.

DİAGH $\mathbb{E}^{\prime}$ NǏ Ŭ , see MERICARP. Dİ̆ $\in H^{\prime} \breve{M} M \dot{A}$ (obs.), see MIEsoPHIYLLUI.

DİÄDẼL'PHǏAN, see DIADELPIIOU'S.

DİÁDKL'PHOǓS, having filaments miterl by their edges in two sets (one of which may be ouly a single stamen), as in the pea.

DİÄGEÕT'RŌPISTM, il kind of geotropic irritability in certain organs, as rootstocks, which causes them to assume a horizontal position; transverse geotropism.

DİÄGNō'sǏs ( $p]$ l. Dĩägnō'sēs), a brief characteristic description of a plint or species.

DİÁGNŎS'TÝC ЄHĂR'ĂCTẼR, see Essential Cilatiacter.

DİĂG'ŌNAL PLĀNES, the two planes which bisect the right angles between the median and lateral planes. See MIEDIAN Puane and Lateral Plane.

DİÁG'ŌN AL PŌS̄ÍTION, a position intermediate between the median aud the literal plane and bisected by the diagomal plane.

DI'ȦGRĂM, FLÖ'RAL, see FLOTRAL DIAGRAM.

DİAHẼLǏ́̆ T'RōPǏSM, the tendency of organs to place their surfaces at right augles to the suu's rays, is most lenves; transverse heliotropism.

DİĂLY̌CÄR POŬS, see APOCARPOUS.

DĪĂLY̌PĚT'ALOǓS, see PoLYPETALOUS.

DİÁLY̌PHY̌L'LOǓS, see PoLysePALOUS.

DİALY̌SĔP'ALOǓS, see PolYSEPALOUS.

DI ĬL' $L^{\prime}$ SISS, the separation of organs usually joined; adesmy. 
When applied to parts of a flower it refers to the separation of organs of the same whorl from each other, as when a normally gamopetalous corolla has its petals distinet. Compare Solution.

DİȦMESǑG'ẢMOǓs, fertilized by the aid of some exterual agent, as wind, water, or iusects.

DİĂ'DRǏAN, see DLANDROUs.

DI ĂN'DROǓs, having two stamens.

DİĂPH'ẢNOǓs, tl'ansparent, or nearly so.

DI'ÁPHRĂGM, any dividing membrane or partition; septum. The term is usually applied to the septum at the node of a hollow-stemmed grass.

DĨ $\mathrm{P}^{\prime} H Y$ Y̌S̆, an old term for the proliferation of a flower.

Dİ'ȦSTẢSE, a ferment genernted in germimating seeds, etc., which ussists in the transformation of starch into sugar.

Dİ̆̌s'TẼR, see DYASTER.

DIĂT'ŌMÍNE, see PHYCOXANTIIINE.

DİCÄR'PĚLLĀRY̌, of two carpels; digynous.

DĪEHĀ'SǏŬM (pl. Dīchā'sià), a false dichotomy in which two lateral shoots of nearly equal strength arise beneath the apex which bears a flower; biparous, dichotomous, or forked cyme. Compare Compound DICHASIUM.

DİEHĂS'TÍC, spontaneously divisling.

Dİ€HLĂMY̆D'Ẽ calyx and corolla.

Dİ€HŏG'ȦMoŭs, having flowers in which the stamens and pistils mature at different times; either protandrous or protogynous. Compare Srinacaic.
DĪEHŎT'ŌMAL FLOWER, one seated in the fork of a dichasium.

DĪEHŏT'ŌMİZE, to fork.

DĪєHǑT'ŌMOǓs, forked; furcate; bifurcate.

DĪєHŏT'0̄MY̌, forking into two brauches of the same nature and usually of about the same size. True dichotomy is caused by the cessation of the previous increase in leugth of a member at the apex, and its continuance in two diverging directions from two newly constituted apices. Compare Hesicond and Scoirpioid Dicho'roms.

DĪCLE'SĬŬM, a name formerly applied to an achenimm having an adherent ealyx, as in Mirabilis.

DǏC'LǏNǒUs, haviug the stamens and pistils in separate blossoms - either monocious or diccious; sepirated; digimuous; unisexual.

Dİcǒc'coǔs, having an ovary consisting of two closed carpels or cocei with one seed in each, as in the Umbelliferz.

DİÇE'LOǓs, having two cavities. DĪCŏTY̌LĚD'ǑNOǓs, having two cotyledons.

DǏD'Y̌MOǓS, in pairs.

DĬDY̌N'MǏAN, see DIDYNAnous.

DĪDY̌N'ÁMOǓS, lıaving two long and two sliort stamens. Compare Tetradyranous.

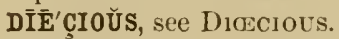

DǏF'FLŪENT, readily dissolving. Compare Deliquescent.

DfFFôRMED', of unusual sliape.

DǏFFRĂCT', said of a lichen thallus which is broken into areolæe separated by clefts or chiuks. 
DǏFFŪSE', spreading widely, loosely, and irregularly. Compare EFFUSE.

DIFFU'sioN, the spontaveous mixture of one liquid with another, or of any dissolved or tinely divided substance or any liquid throngh a liquid or solid. Compare Osirose.

DĬG'ẢMOǓs, see Diclixous.

DĬ'G'ENOǓs, containing both sexes or produced sexually. (Rale.)

DÍG'ǏTĀTE, having several parts radiating from one point, or nearly so, somewhat like the tingers on one's hand. Applied in grasses where several sjikes railiate from nearly the same point, as in crab-grass (Sanguinaria). In lesves it is the same as Palmately-compound. Compille Pedate.

DÍG'ǏTĀTE PĬN'NĀTE, having a digitate leaf with pinnate leaflets.

DÍĞ ǏTĀTE-VEINED, see PALYATELY-VEINED.

DÍG'ǏTǏFôRM, see DiGitate.

DÍG'ǏTINẼRVED, see PALMATELT-YEINED.

DĬG'ONOǓs, $t$ Toro-angled, as the stems of some cicti.

DÍGỸN'ǏAN, see Digrsots.

DĬG'Y̌NOŬS, having two pistils, st rles, or stigmas in a flower. Generally the same as Dicarpellary.

DĪLĂMINA ÁTION, see CHORISIs.

DÍLĀT'ĚD, expauded or widened. DǏM'ẼROǓs, having the parts in twos, as two sepals, two petals, two stamens, aud two pistils in a flower.

DǏMǏD İĀTE, halved, or appearing as if oue sicle or one half were wanting, as a leaf which is developed on one side of the midrib only. Compare $\mathrm{OB}$ Lique. Applied also to the calyptia of mosses when divided aloug one side. The term is also applied to bodies which are actually halved or divided into two parts, and to tlose in which one side differs from the other in function.

DĪMÔR'PHOǓs, existing under two forms. as two forms of leaves, sterile and fertile, on one plant in ferns. Applied especially to lieterogonous plants having two forms of flowers on separate individuals, one with long stameus and short styles and another with short stamens and long styles. Compale Trimorpilous.

DĪE'ÇAN, see DICECIOL'.

DĪE'ÇIOǓs, having stamens and pistils in separate flowers upon different individuals.

\section{DĪE'CIOǓSLY̌ PŌLY̌G'ẢMOǓS,} when some of the tlowers in diceious plants are perfect. Each set of pliuts may have perfect as well as uuisexual flowers, or one set may have all perfect flowers and the other all staminate or all pistillate; polygamo-diœcious.

DI'ǑsMŌsE, see Osuose.

DİP̌T'ALOǓs, haviug two petals in a tlower.

DĪPHY̌L'LOǓs, two-leaved. Having two leaves, leatlets, or leaflike parts. Sometimes used for Disepalous.

DIPLĂN ĚTǏsM, the property of being twice active with an interveuing period of rest. It occurs in the zoöspores of certain genera of Saprolegnieæ in which the zoöspores escape without cilia from the sporangium and come to rest in a 
cluster each forming a cellwall. After some hours of rest the protoplasm of each spore escapes from its cell-wall, acquires cilia, and enters upon a period of active movement.

DǏP'LŌẼ, see MESOPHYLL.

DǏPLŌǴĔN'ẼsIS, the duplication of parts normally siugle.

DǏPLŌPẼRǏS'TŌMOǓS, said of the capsule in mosses when the peristome consists of a double row of teeth. Compare AploPERISTOMOUS.

DǏPLŌSTĚM'ŌNOǓS, havịg the stamens in two whorls, those of each whorl equal in number to the petals, which are in one whorl. Compare IsostemoNOUS.

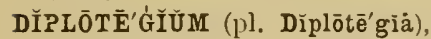
an inferior capsule, as in Caupanula.

DĬP'TĚROǓS, two-winged.

DÍREC'TION-ÇĚLLS, see POLAR C'ELLS.

DǏRĔC'TION-CÔR'PǓSÇLES, see Polar Cells.

DǏRĔCT' MĔTĂMÔR'PHŌSǏs, see Progressive MetallorphoSIS.

DĬRĚCT' SŪPẼRPŌŠÍ'TION, the situation of accessory buds in an axil above the leading bud or one first formed, as is usually the case in superposition. Compare Inverted SUPERPoSITION.

DÍŘMP'TION, see DISPLACEMENT.

DISÄRTÍC'ŪLĀTE, to separate at an articulation or joint, as most leaves in antumn.

DǏSC, see DISk.

DİS'ÇǏFôRM, disk-shaped; flat anil circular.

DǏSÇİG' Ẽ ROǓS, disk-bearing, as the wooly tissue of conifers.
DǏs'CōCÄRP, an ascocarp in which the hymenium lies exposed while the asci are maturing, as in Peziza. The term has also been applied to fruits like the rose and fig, in which the receptacle is expanded and forms the main part of the fruit, enclosing the seeds or acheuia.

DÍscōD, disk-shaped; flat and circular; belonging to the disk, as the central florets in a head of Compositie.

DǏS'COID FLOWẼR, a head of flowers in Composita in which each flower is tubular.

DIS'COTDD MÄRK'ÍNG, see BorDERED PIT.

DISCOL'ŏR, of more than one color; variegated; especially having the two surfaces of a leaf differing in color, as in the begonias. Compare UxicoloR and CoNCOLOR.

DǏS'COŬS, disk-shaped.

DǏSCRẼTE', distinct; separate. Compare Concrete.

DǏs'CŬS, see Disk.

DĪSĚP'ALOǓS, of two sepals.

DISK, any Hat, circular area: the central part of such an area or of any flat body as opposed to the border: disc. Especially (1) the central part of a head of flowers in Composita, generally bearing tubular florets only; (2) the portion of the receptacle of a Hower between the stamens and pistil, often more or less dilated and serving as a nectary; (3) a circular borlered pit, as in Conifer' (4) the circnlar adhesive base (retinaculum) of a pollinium.

DǏSK FLŌ'RĚT, see 'TUBULAR FLORE?.

DǏSK' FLOWẼR, see 'TUBULAR Floret. 
DǏSK'-SHĀPED, tlat and more or less circilar; discoid.

DISLŌCA'TION, see DISPLACEIENT.

DǏsōPẼR'CŪLĀTE, having lost the opereulum or lid. Compare DEOPERCULATE.

DISSPLĀÇE'MENT, the situation of an organ out of its normal position; dislocation; diremp. tion.

DǏsSĚCT'ĚD, cut deeply into many lobes or divisions. Compare LACINIATE and Divided.

DǏsSĚMǏN $\bar{A}^{\prime} T I O N$, the natural dispersion of seeds.

DǏSSĚP'ǏMENT, one of the double walls separatiog the cells of a syucarpous ovary; septum. Comprare False Dissepimen's,

DISSSIL'ǏENT, dehiscing with elastic violence, as the pod of Impatience.

DǏssōÇİÁ TION, separation.

DIS'TAL, pertaiuing to the apex or outer extremity. Compare Proximal.

DǏ'TANT, laving larger intervening spaces than usual. $\mathrm{O}_{\mathrm{p}}$ posed to Dense or Approximate.

DǏS'TÍ EHoǓS, two-rauked, as the leaves of grasses. Applicd also to leaves arranged like those of the fir, which are turned in two directions, though not inserted oppositely in the same plane. In this latter sense Bifarions is somewliat the better term.

DÍSTǏNCT', when parts of the same kind are unconnected; opposed to Coherent. Com. palle FreE.

DǏSTRĂC'TĬLE, widely separated. Applied mainly to authers in which the conuective is developed so as to keep the lowes wide apart, as in Salvia.

DİTRĪ€HOT'ŌMOǓS, dividing into two or three branches.
DĪÛR'NAL, said of flowers which open in the day and close at night.

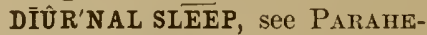
LIOTROPISI.

DİVăR'ǏCĀTE, divergiug at a widle angle.

DǏVẼR'GENÇE, see ANGLE OF DIVERGENCE.

DǏVẼRSİFLō'ROǓS, laving flowers of two or more forms.

DǏVĪD'ĚD, having incisions exrencling to the midrib. Compare Cleft and Parted.

DōDĒCĂG'Y̌NOƯs, having twelve pistils.

DŌDĒCĂM'ẼROǓS, having the Horal orgaus in twelves; 12merous.

DŌDẼCĂN'DROǓS, having twelve stamens.

DŌDĔCĂPĔT'ĂLOǓS, h twelve petals.

DōLĂB'RIFôRM, lıaviug the form of an axe or hatchet, as the leaves of Mesembryanthemum dolubriforme.

DŌMĚS'TǏCĀTĚD, introduced and found to thrive and reproduce itself under cultivation. It does not neeessirily imply any change of elaracter.

DÔR'MANT BǓD, one which is poorly developed and which under ordinary ciremustauces will not grow into a branch. Often the first-formed buds on a season's growth are of this character; latent bud.

DÔR'MANT STĀTE, the condition of a living plant during winter, or other definite periorl of cessation from active growth; lintent period.

DÔR'SAL, pertaining to the back, or situated upon the back. The dorsal surface of a leaf or other foliar organ is the anterior, 
outer, or normally lower surface. Some botanists, however, apply the term dorsal to the upper surface. Compare VENTRAL.

DôR'SAL SÜ'TŪRE, one situated at the midrib of the carpellary leaf.

DôRsǏCǓM'BENT, see SUPINE.

DôRSǏF' ẼROǓs, beuring the fruit upon the back, as the spores of many ferns; dorsiparous.

DÔRSĬP'ĂROǓS, see DORSIFERoUs.

DôRSĬVĔN'TRAL, having a distinct frout and back, as leaves.

DôR'SŬM, the back of any organ: the outer or lower surface of leaves or parts of a Hower. See also Dorsal.

DôR'TY̌, (Hort.), delicate; difỉcult to cultivate. (liare.)

DŏT'TĚD, see Punctate.

DǑT'TĔD DŬCT, see PITTED VEsSEL.

DOǓB'LE, having more than one whorl of petals. A flower is completely double when all the essential organs are replaced by petals.

DOÜB'LY̌-COM'FOUND, t $\mathrm{w}$ i c e compouml, as bipinuate or bipalmate.

DOÜB'LY̌-CRE' $\bar{E}^{\prime} \mathrm{NA} T E$, having the crenatures or teeth of a crenate leaf again crenate.

DOǓB'LY̌-DĚN'TĀTE, having the teeth of a dentate leaf dentate. Compare Bidentate.

DOǓB'LY̌-PINN'NĀTE, see BIPIXNATE.

DOǓB'LY̌-SĔR'RĀTE, ha v ing small serratures upon the large ones, as in the elm. Compare BiserRate.

DOǓB'L Y̌-TẼR'NĀTE, see BI'TERNAT'E.
DOǓB'LY்-TOOTHED, having the teeth themselves toothed, as in Doubly-dentate.

DOWN, soft short pubescence.

DoWN'Y̌, having a dense covering of short weak hairs.

DRAWN, elongated by absence of light, as plants which are crowded together.

DRĚP'ÁNǏFôRM, see FALCATE.

DRDOOP'ING, inclining downward more than cermous and less than pendent or pendulous.

DRỰPA'ÇEOǓS, like, or pertaining to, a drupe; producing drupes, as drupaceous trees.

DRUPE, a stone-fruit, as the peach, almond, and cherry. It consists of one carpel, with usually a single seed surrounded by a thickened bony endocarp called the pit or stone.

DRU'PEL, a very small drupe, as the so-called seeds of the blackberry.

DRUPE'LĚT, see DIRUPEL.

DÜ'BǏOǓS, doubtful.

DŬCT, see VESSEL.

DǓL'CIs, devoild of acidity: sweet.

DŨMōsE', laving the form of a bush or low compact shrub.

DŪ'MǓs, see Bưsil.

DÜ'PLǏCĀTE, doubled or folded.

DU' $\bar{U}^{\prime} P L \check{I} C \bar{A} T E-C R \bar{E}^{\prime} N \bar{A} T E, \quad$ s e e

DOUBLY-CRENATE.

DÜ'PLǏCĀTE-DĚN'TĀTE, se e DOUBLY-DEN'TA'TE.

DŪ'PLICCĀTE-ŠKR'RĀTE, S $\mathrm{C}$ DOUBLY-SERRATE.

DÜRA'MĚN, henrt-wood; the central portion of the trumk of most exogens, consisting of wood of darker color and denser lexture than the outer newer layers, and possessing 
the claracteristic color of the species.

DWA ARF, habitually attaining much less than the ordinary size of related species or varieties; nanus. Compare $\mathrm{Hu}$ MILIS and DEPAUPERATE.

DWARF MĀLEȘ, very small iudividuals in (E)dogoniere, originating from special swarmspores called androspores, and produciug only antherozoids.

DỸ $\mathbf{A} S^{\prime} T \tilde{E} R$, a stage of karyolinesis succeeding the monaster or mother-star stage and ending with the formation of the diughter-skeins. During this stage the chromatle filaments are grouped about the poles, the iwo groups (asters) being more or less united by the spindle finres or conjunctive threads. See Daughter-stak.

Е- or EX-, a prefix meaning destitute of, outside of, or away from.

EAR, a prominent lobe, as those at the buse of the leaf in sorrel (Rumex acetocelli).

ĖARED, see Auriculate.

ËBE' NẼOǓs, black like ebony.

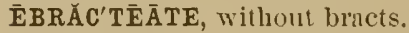

EBÛR'NĒOǓS, ivory-Wlite.

ECĂL'CÁRĀTE, without a spur.

ẼCAU'DĀTE, without a tail or tail-Jilie appendage.

ĔCBLĂSTẼ'SǏS, the prorluction of butls within a flower in consequence of lateral prolitication.

ĚCČ̌N'TRĬC, out of the centre or axis; not having the same centre; when the centre or axis of growth dloes not foincile with that of the mass, as in most starch-grains, or in trees which develop more rapidly on one side than on the other.
ĚCH'ǏNĀTE, spiny or prickly.

EิEHǏN'ŨLATTE, dimiuutive of Echinate; having small prickles.

\section{ĖČID'ǏU, see EcIdIUr.}

ÉCŌNǑM'ǏC BǑT'ÁNY̌, the classification of useful and injurious plants, and the stucly of all botanieal questions liaving a practical bearing. See AciriCULTURAL Botany.

ËCǒS'TĀTE, withoul a rib.

ĚCTŌĞ'NǏC, capable of living outsicle of an animal body. Said of certain disease-producing orgunisms, as the bacillus of anthrax.

ĔC'TŌPLĂȘ, a lyaline layer of protoplasm free from grauules next to the cell-wall; byaloplasm.

ÉC'TŌSPŌRE, sce BAsIDIOSPORE. ÉCTŌSPŌ'ROǓs, sce Exosporots.

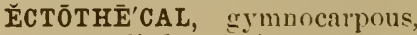
as applied to Ascomycetes. (Rare.)

EDĚN'TĀTE, without teeth, as an entire leaf.

ĚDǴED, see MATGINATE.

ĚFFẼTE', exhaısted; no longer poductive or fruitful: past the bearing age.

ĚFFLŌRĚS'C̣ENC̣E, the time or act of flowering.

ĚFFŪSE', spreading loosels, especially on one side, as the panicle of Juncus effusus. Compare Diffese and SECIND.

ĚGG-ĂPPȦRĀ'TǓs, a group of three mucleated hodies at the upper end of the embryo-sac, which together with the upper polar nucleus correspond with the antipodal cells. 'The central deeper cell of the egg-apparatus beromes the oösphere, the others form the elongated 
synergidæ; germinal apparatus.

ĔGG ÇĚLL, see OÖSPHERE.

ĒFŬL'CRĀTE, saidl of buds from below which the leaf has fillen. (Rare.)

ẼGĂN'DŪLŌSE, without glands.

E'GRĚT, see AIGRE'T.

Eİs'ŌDAL, anterior. Applied to the outer or anterior part of the opening of a stoma. Compare OPISTHODAL.

EJĚC'TION, throwing out with force, as spores from a sporangium or seeds from a pod. Compare ABJection.

ÉLĂBŌRÄ'TION, a term applied to the changes which lake place in plant-food after it is absorbed, to prepare it for the use of the plant. Compare Assimlation aud Metasta. SIs.

ĚL'ÄTẼR, a term for varions elastic, usually spiral, bodies which serve for the clispersion of spores, as those in the cap sules of mosses and hiverworts and those at tached to the spores of Equisetum.

ĚLA'TE'RIUUM, a term sometimes applied to fruits which discharge their seeds by means of elastic carpels, as in certain Euphorbias; regma.

ĒLEŪTHẼRŌPĚT'ȦLOǓs, s e e Apopétalous.

ĒLEŪTHẼRŌPHY̌L'LOŬS, S e 3 APOPHYLLOUS.

ẼLEŪTHẼRōSÉP'ÁLOǓs, se e Aposepalots.

ÉLLǏPSOID'AL, nearly elliptical in outline.

ĚLLǏP'TǏCAL, oblong, and rounded at the ends; longer than oval.

ĚLLİP'TǏC-LĂN'ÇĒōLĀTE, intermediate between elliptical and lanceolate, but approaching the latter.

ẼLŎC'ŪLAR, see UNILOCULAR.

ELLON'G'GTĚD, exceeding the usual or a verage leugth.

ẼLYัT'RIFFôRM, resembling the wing-cover of a beetle; elytroid.

EMÄR ÇID, flaccid; wilted. (Obs.)

$\bar{E} M \ddot{A R} R^{\prime} G \breve{I N} \bar{A} T E$, notched at the end. Sonetimes applied to organs which are notched at other places, as to the gills of mushrooms when notched or cut out before reaching the stem.

ĔMBǑSSED', see UMBONATE.

ĖMBRĀÇ'ǏNG, clasping by a broad surface. Compare AuPLECTANT and Sheathixg.

ÉM'BRY̌ō, the rudimeutary plaut within the seed.

ĚM'BRY̌Ō-BǓD, a rudimentauy bud, especially if adrentitious.

ĚM'BRY̌ō-Č̆LL, see OÖsPHEIE.

ĚMBRY̌ ŌĠ̌́N'ÍC, pertaining to the levelopment of an embryo.

ĚMBRY̌ŎG'ENÝ, embryo-formation.

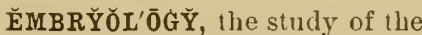
embryo and its development.

ĔM'B̈RY̆ǑNAL ÇĚLL, see Ö̈SPHERE.

ĚM'BRY̌ŎNAL VĚS'ǏCLE, see OÖSPHERE.

ĚM'BRY̌ōNĀTE, having an embryo.

ĚMBRY̌ŏN'ǏC, in an early undeveloped condition; rudimentary.

ĚM'BRY̌ō NǑD'ŪLE, a term applied to small knots, frecuently about the size of a pea, found beneath the bark in certain trees, and sometimes containing one or more rulimentary buds. 
ĔMBRY̆ðN'ǏC SĂC, see EurRYoSAC.

ĚMBRY̌ON'ǏC VĔS'ǏCLE, see Ö̈SPHERE.

ĔM'BRY̌ Ō-SÁc, a large cell in the nucleus of the ovule within which the germinal vesicles or ö̈spheres (one or more) are produced, and which finally contaius the embryo. Compare Central Cell.

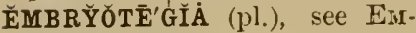
BIYYTEGIUM.

ĚMBRY̌ōTE'ĞĽŬM (pl. Е̌mbry̌ōtế' (Gia), a small cap covering the micropyle in certain seeds, as asparagus, and detached by the radicle in germinatiou.

ĖMẼR'GENČ̆ES, a term applied to outgrowths of various kinds derived from the fundamental tissue below the epidermis, and covered by the latter, as the prickles of the rose.

EMẼR'GENT, protruding through or elevated above surrounding parts.

E'MÈRSED', jaised out of water.

ĚMPĀLE'MENT, an old term for calyx.

ĚMP'TY GLŪMES, oue, two, or more bracts or scales subtend. ing a spikelet in grasses, and enclosing one or more flowers: outer glumes. Formerly called merely glumes. Compare Flowerina: Glume.

ẼNĂNTÍ̄̄BLĂS'TǏC, a term sometimes applied to the embryo of o.thotropous seeds. Compare Homoblastic.

$\bar{E} N \bar{A}^{\prime} T I O N$, having outgrowths or excrescences the result of excessive developmeut, as scales upon petals. Compare СноRISIS.

$\breve{E} N \in H Y L L \bar{E}^{\prime} \mathbf{M A}$, the unorganized proteids in living cells, as aleurone graius. (Haustein.)
ĔNÇY̌S'TĚD, euclosed in a cyst or sac. Applied, for example, to a stage of growth in Protococcacere in which the iudividual exists as a free cell with a cell-wall, but destitute of cilia.

ĚNDĒCÁG'Y̌NOǓS, haviug eleven pistils or styles.

ĚNDẼCAN'DROǓS, having eleven stamens.

ĚNDĚCAPHY̌L'LOŬs, said of a leaf containiug eleven leaflets.

ĚNDĔM'Ǐc, occurring in the one limited locality or region only. Compare Sporadic.

ĚNDŌBĀSǏD'Ǐ basidium, as in Gasteromy. cetes.

ÉN'DŌCÄRP, the inner layer of a pericarp, particularly if developed in a special mauner, as the pit of a peach or core of an apple.

ĚN'DŌ€HRŌME, coloring matter in cells, or colored cell-conteuts aside from clilorophyllused mainly in algre. Often applied to the entire cell-contents of algx, and sometimes to colored cell-contents in other plauts, but less used now than formerly.

ĚNDŌDẼR'MǏs, a layer, of one or more cells in thickness, which forms the inner boundary of the cortex and surrounds the fibrovascular cylinder.

ĚNDǑG'ENOǓS, produced within auother body. Applied also to the stems of monocotyledons and their manner of growth, which was formerly supposed to take place chiefly at or near the centre.

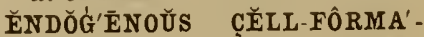
TION, see FreE CELL-FORMATION. 
ĚNDŌGŌNǏD'ǏÙM, a gouidium formed within a leceptacle, as in the sporangium of Mlıcorini.

ĚNDŌPĚRĬ'Ǐ UัM, the iuner peridium when there are more than one, as in Geaster.

ĚNDŌPHLĒ'ŬM, inner bark; liber. See BAsT.

ĚNDŌPHY̌L'LOǓS, enclosed in a leaf or sheath, as the joung leaves of monocotyledons.

ĚN'DŌPHȲTAL, growing within other plants; entophytal.

ĚN'DŌPHȲTE, a plant which grows within another, either parasitic upon it or not; entophyte.

EN'DŌPLĂSM, the internal granular portion of the protoplasm; when distinguished from an outer layer free from granules called Eetoplasm.

ENDŌPLEŪ'RÄ, see TEgMEN.

ĚNDǑP'TÍLE, an old term applied to the plumule of endogens.

ĚNDŌRHİ'ZA (pl. Ěndōrhīzæ) an old term for endogen.

ĚNDŌRHI'ZAL, said of an embryo in which the radicle is sheatlied by the cotyledons wrapped around it. Applied also to the method of germiuation in endogens.

ENDŌRHĪZOǓs, see ExDORHI$\mathrm{ZAL}$.

ĚN'DǑSMŌSE, an in ward curreut established between fluids of different densities when separated by an animal or vegetable membraue: endosmosis. The absorption of moisture by roots is due to endosmose. See OsMose.

ĚNDǑSMŌ'sǏs, see ExDOSMOSE.

ĚN'DŌSPẼRM, the albumen of the seed, especially when formed in the embryo-sac. Compare Perisperu.

ĚN DŌSPŌRE, the iuner coat of a spore.

ĚN'DŌSTŌME, the orifice of the inner coat of the ovule, i.e., the inner portion of the foramen. Compare Exostosie.

ĚNDŌTHË'ÇĬŬM, the lining (tapetum) of an anther cell, consisting of one or more layers within the exothecium.

ĚNDŌZŌ'Ǐc, living inside an animal; entozoic.

ĚNNẼ̂́'́'ÝNOǓS, having nine pistils or styles.

ĔNNEĂN DRİAN, see ENNEAXDROUS.

ĚNNĔĂN'DROǓS, having nine stamens.

ĚNNĖȦPĚT'ALOǓS, haviug nine petals.

ĚNNĒẢSĚP'ALOǓS, having nine sepals.

ĚNNẼȦSPẼR'MOǓS, nine-seeded.

$\bar{E} N \bar{O}^{\prime} \mathbf{D A L}$, without norles.

ĚN'SĀTE, see ExsiForग.

ÉN'SIFF̂RM, sword - shaped; straight, or nearly so, twoedged, and tapering very gradually from base to apex, as the leaves of iris; gladiate.

ĚNTIRE', having margins lestitute of teeth or notches.

ĚNTŌMǑG'ẼNOǓS, growing upon insects, as certain fungi; entomophytous.

ĚNTŌMŎPH'ǏLOǓS, adapted to polliuation by iusects.

ĚNTŌMǑPH'Y̌TOŬS, see ExTo. MOGENOUS.

ĚNTŌPĂR'Ás̄̄TE, a parasite living entirely within its host.

ĚN'TŌPHȲTAL, see ExDOPHXTAL.

EN'TŌPHȲTE, see ExDOPHYTE.

ĚNTōZō'Ǐc, see ExDozolc. 


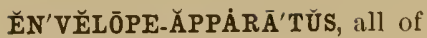
the ascocarp except the ascnsapparatus.

ĒPǍN'ŌDY̌, a general term for reversion from an irregular to a regular condition. In flowers it is termed "regulal peloria."

ËPĂN'THOǓs, growing upou Howers, as certain fuugi.

ĚP'ĚN, see EPENCIYMA.

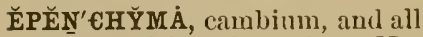
tissue arising from it. (Niigeli.) Compare ProtesCIIYMA.

ËPHĚM'ẼRAL, lasting but a day or a very short time, as the corolla of purslaue.

ĚP'ǏBLA்ST, a term applied to a small scale-like appendage in front of the embryo and opposite the scutellum in the seeds of rice and many other grasses. (F. L. Scribner.)

ĔPǏBLE'MÁ, a collective name for the epidermal cells of a young organ, especially a root, including the root-hairs. (Obs.) See EPIDERMIS and DeriatOGEN.

ĚPĬCA'LYX, au involucre resembling an exterior calyx, as in unallow.

ĚP'ǏCARP, the outer layer of a pericarp.

ĚP'ǏєHǏL, see EPICHILIUม.

ĔP'ǏєHĬLE, see Eрichilum.

ĚPICHǏL'ǏUM, the upper or distal portion of the labellum of an orchid, when especially different from the lower or basal portion. Compare HrpoCIIILIUM.

ĚPǏCLI'NAL, seated upon the recejtacle.

ĚPICôR'MǏC, applied to side branches which develop on the body of a forest tree from which surrounding trees have been removed.

ĚPǏCŌR̆L'LǏNE, upon the corolla.

ĚPǏCŏT'Y̌L, the portion of a young stem between the cotyledons and the lowest true leaves. Compare Caulicle.

ĚP'ǏDẼRM, See EPIDERIIS.

ĚPIDẼR'MAL, pertainiug to the epidermis.

ĚPİDẼR'MǏs, the exterual layer of cells in a plaut. Compare Cuticle aud Deriatogen.

ĚPǏDẼRMOI'DAL LĀY'ẼR, a term sometimes applied to an onter layer of cortical cells borlering on the epidermis.

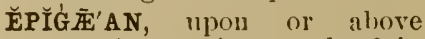
ground; growing on laud iu distiuction from water; growing close to the earth, as some leaves; rising above ground instead of remaining beneatl, as the cotyledons of beans; epigreous.

ĚPÍGE'AL, see EPIGAAN.

ĚPǏGĽN'ÉsǏs, (1) origiuating upon another body; (2) the theory that the embryo is the joint product of both sexes, as distinguished either from the doctriue that the male parent furnishes the germ and the female simply the nidus or resting-place in which it is nourisher, or from the theory that the female furuishes the germ which is merely quickened by the inthence of the male. Seldom used in botayy. ËP̌́' surface or on the upper surface, as a fungus on its host. Compare Hypogenous and EDOGENOUS.

ĚPǏGE'OǓS, see EPIGÆAN. ĚP' ĬGŌNE, see EPIGONIUM. 
EPIGG'NI İU, the archegonium in mosses after the capsule has developed. It is frequently ruptured, a part being carried up to form the calyptra, and a part remaining at the base of the sporangium or its stalk, as the ragimule. Also an homologous sac enclosing the young sporangium in Hepatica.

ẼI İG'Y̌NOǓS, growing upon the ovary.

ĚPİNÀS'TǏc, denoting curvature resulting from growth on the upper side of an organ making it curve dowuward. Compare HYPONASTIC.

ÉP'INĂSTÝ, that state of a growiug dorsi-ventral organ in which the upper surface grows more ripidly that the lower.

ĔPǏPĔT'ALOǓs, upon the corolla.

ĚPǏPHLE'ŌDAL, upon the epiderm is or outer surface. Compare IIYPOPHLEODAL.

Е̌PIPHLE' UัM, see CORKY LAYER. Ё'ÍPHRĂGM, a menbrane closing the mouth of the capsule in mosses; also a delicate membrane closing the cup-like sporophore in Niclularia.

ĚPǏPHY̌L'LOǓS, growing $\mathrm{Ol}^{\circ}$ inserted upon a leaf, or upon the upper side. Compare HrpoPHYLLOUS.

ĚP'ǏPHŸTAL, see EPIPIITIC.

ĚP'ǏPHȲTE, a plant growing upon another but not nourished by it : air-plant. Compare Paliasite.

ËǏPHY̌T'ǏC, growing u pon another plant but not nourished by it; epiphytal; pseudoparasitic.

ĚPǏPHȲTǑT'ǏC, a term applied by Erwin F. Smith to any wide-spreading disease among plants, corresponding to an epidemic amoug men or an epizoöt ic amongr animals.

ĚP'IPLĂȘM, protoplasm which remains in an ascus or other unicellular sporangium after the formation of the spores.

ẼPIP'TẼROǓs, winged at the alpex.

ĚPǏRRHĒŏL'ō'Ğ, the portion of physiological botany which treats of the effects of external agents on living plants. (Rare.)

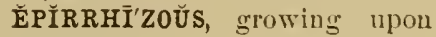
roots.

ĚP'ÍSPẼRM, the seed-coat, espe cially the outer coat or testa.

ĚPISPŌRĂN'ǴĬŬM, an oll term for indusium.

ĚP'ÍSPŌRE, the outer coat of a spore; exospore.

ËPİ'TRŌPHE, said of chlorophyl-bollies when they talie their position aloug the outer wall of the cell, nsually when the light is of medimm intensity. Compare Apostrophe and SrstroPHE.

ĚPITTHĂL'LINNE, growing upon the thallus.

Е̌PITHE' $\bar{E}^{\prime} \mathbf{I} \breve{U} \mathbf{M}$, any distinct layer of one or more cells in thickness bounding an internal car. ity. Formerly applied also to delicate epidermis of rootlets and other exterual parts.

ẼIXX'Y̌LOǓs, growing upon wood, as many fungi.

ĚPǏZō'ǏC, growing upon living auimals, either parasitic or not.

EQUAL, symmetrical; regular; of the same number; like another in all respects, or in lengtl.

E'QUALIY̌ - PǏN'NĀTE, S e e ABIRUTLYYPINNATE.

EQQUAंTó'RĬAL PLĀNE, the plane which passes through the equa- 
toria] plate (mother-star) of the cell-uucleus, or between the parts when the plate has divided, and which occupies the position of the future cellwall. It is the plane of celldivision.

ẼQUÁTō'RĨAL PLĀTE, see MOTHER-STAR.

ẼQUǏLĂT'ẼRAL, equal - sided; opposed to Oblique.

ẼQUINǑC'TIAL, sail] of flower's which open and close at particular hours of the lay.

ĔQ'UǏTANT, having the leaves so arranged that the base of each is enclosed within the opposite base of that which is next below it, as in the iris. Compare HALF-EQUITANT.

ẼQǓVĂL'VŨLAR, laving the valves of a cilpsule all of the same size.

ĒQUǏV'ŌCAL GंĚNĚR $\bar{A}^{\prime} T I O N$, see Spontaneuus Gexeration.

ERĂDIC'ŨLōSE, without rootlets or rhizoids.

ĒRĚCT', perpendicular, or nearly so, to the surface to which it is attached; standiug without support, not weak or lax. Compare Strict. Applied to ovules or seeds it means growing vertically from the base of the ovary. Compare AscexdING and INVERTED.

ERĔCTŌPĂT'ENT, intermediate between erect and spreading.

ẼR'́nōBLĂST, a unicellular plant. (Sachs.)

ĚRǏĂN'THOǓS, woolly-flowered.

ERĬCĀ'CEOǓs, heath-like.

ER'ICOID, ericaceous. Said of a subulate form of leaves often fouvd upon the juniper.

ĚRĪōPHY̌L'LOǓS, woolly-leaved. ERŌ'DĚD, see ERose.
ẼRōSE', laving irregular sinuses as if bitten out; eroded.

ĒRǑS'TRĀTE, without a beak.

ERŬM'PENT, breaking out, as the spore clusters of some fungi through the epidermis of their lost.

ẼRYTH'RŌPHY̌L, red coloring matter in plants.

ĚS'CULLENT, used for food by man.

ÉSĚP'TĀTE, witlınut septa.

ÉSōTĚR'ǏC, origiuating within the organism. Compare ExOTERIC:

ĚSSĚN'TIAL €HĂR'ĂCTẼR， a feature which distinguishes a plant or group of plauts from all others; diagnostic character.

ĚSSĔN'TIAL ÔR'GANS, stamens and pistils.

EัSTI' VAL, pertaining to summer; restivil.

ĚS'TǏVĀTE, to pass the summer in a dormant condition. Compare HilserNate.

ĔSTǏVÁt'TION, (1) the arrangement of the floral organs in the bud-usually written Estivation; (2) passing the summer in a dormant condition.

ÉT社'RĪo, a term somelimes applied to such fruits as the raspberry and blackberry.

E'TǏōLĀTĚD, blanched by exclusion of light. Compare CHLORosis.

EŪCYYC'LǏC, applied by Braun to flowers having the members in each whorl equal in number and alternating will those in all adjoining whorl.

EU'́PYY̌LL, an ordinary foliageleaf. See Phyllome.

EŪTRŎP'ǏC, twining or turning with the sun; dextrorse.

ĒVăLV'ŨLAR, without valves. 
ĚVȦNĚS'ÇENT, (1) soon passing away; (2) applied to veins which disappear before reaching the mirgiu of the leaf.

EVEN-PIN'NĀTE, see ABRUP'TLYPINNATE.

ÉV'ẼRGREEN, haviug green leaves throughout the year, as most Conifer:e.

ĚVẼRLȦST'ING FLOWẼRS, see IIIMORTELLES.

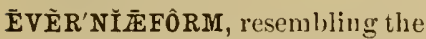
thallus of the lichen Evernin.

$\bar{E}$ ẼR'SION, the protrusion of a part which is generally produced in a cuvity.

ĒVẼRT'ĚD, turned iuside out.

Ě ÍDENT, distinctly visible.

Ẽ IIT'TĀTE, without vitte, which see.

ĚVōLU $\bar{U}^{\prime} T I O N$, the act of unfolding or unrolling; hence growth or development, especially the supposed development through successive geuerations of the higher from lower or simpler forms of life, both in animals and plauts.

ĚXĂLBŪ'MǏNOǓs, haviug the nutriment in the seed all stored in the cotyledons.

ĚXÁN'NŪLĀTE, without an anmulus.

ĚXĂR'ǏLLĀTE, withont an aril.

ĚXĂS'PẼRĀTE, covered with short hard points; muricate.

ÉXCEN'TRIC, ont of the centre; abaxial. An embryo is excen. tric when it lies within the albumen, but not in the centre of it, as in asparngus; the trunk of a ree is excentric when developed more on one side of the heart than on the other.

ĚX'ÇIPLE, see ExcıPuidu.

ĚX'ČrŪLE, see ExcIPULU.I.

ĚXçI'P'ŪL ŬM, the portion of the thallus supporting or surround- ing the apothecium in lichens. In some cases the excipulum is an outer rim of the perillecium itself, and is then termed a "proper" excipulum.

ÉXC̄TȦBĬL'ǏTÝ, the general facnlty, characteristic of living bodies, of being influenced by external stimuli. Compare IRIRTABILITY.

ĚXCR ĚS'CENT, growing out in a morbid or unnatural mauner, as a wart or tumor; superfluous.

ÉXCR $\bar{E}^{\prime} T I O N$, the separation of unassimilable mitter from an organism. Compare SEcreTION.

ĚXCǓR'RENT, projecting beyond the usual limit, or to the extreme summit or apex.

ĚXF $\bar{O}^{\prime} \mathbf{L} \breve{I A T E}$, to cast off layers or plates, as the bark of sycamore.

ĚXHẢLA'TION, see TRANSPIRATION.

ĚXIG'ÜOǓs, small or slender. See Gracile.

ĚX'ǏNE, see EXTINE.

EXǏN'TǏNE, a term applied by Fritscle to a third coat observed by him in the covering of certain pollen-grains between the iutine and a secoud coat called by him the intexine. The terms Iutexine and Exintine are not in ordinary use and do not represent any constant recoguized structures.

ĚX'ŌÄRP, the onter layer of a pericilp.

ĚXOG'G'ENOǓS, growing by addition to the outside, or springing from the exterior tissues. Applied also to the manner of growth of the stem in ordinary trees (dicotyledons and gymnosperms).

ĚXŏG'Y̌NOǓS, having the style exserted beyourl the corolla. 
ĚXÖPẼRID'ǏUM, the outer peridium when there are more than one, as in Geaster.

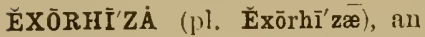
old term for exogen. Compare ENDORIIIZA.

ĔXōRHI'ZAL, the manner in which the radicie of dicotrledons is developed !n germina tion. (Rale.)

ĚX'ÖSMōsE, the passage of gases or liguids through a closed membrane from within ontwarl, or from the denser to the rarer Huid in the process of osmose.

ĚX'ŌSPŌRE, see EPISPORE.

ĚXŌSPŌ'RI IUM, see EPISPORE.

ĚX'0̄STōME, the orifice in the onter coat of an ovule or seed, which with the endostome forms the foramen.

EXX̌sTō'sǏs, any indurated protuberince.

ĚXōTĚR'ǏC, having its cause or origin outsicle the orgunism. Compare Esoteric.

EXōTHE $\bar{E}^{\prime}$ CIU $\mathrm{M}$, the outer coat or epiclermis of an antler. Com. pare ENDothecica.

ĚXŏT'ǏC, introduced from a foreigu conntry.

ĚX'PLȦNĀTE, splead or flattened ont. Appliel to a part usually rolled or foluled. Compare Complanate.

ĚXSẼRT'ĚD, protruding beyond the margin of a receptacle, as stamens beyoud the corolla, or a panicle of a grass above the lenf-sheath.

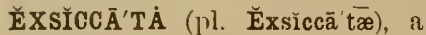
dried herbarium specimen; exsiccate.

ĔX'SǏCCĀTE, see ExsICCATA.

ĚX'SǏCCĀT LD, dried; especially, collected and dried for preservation as a botanical specimen.
ĚXSTǏP' ŪLĀTE, without stipules. EXXǓC'COǓS, destitute of juice.

EXTE'RIOR, when applied to the parts of it flower, means the sime as Anterion, i.e, the side away from the axis; lower; onter.

ĔX'TINE, the outer coat of a pollen-grain. (Exille of Schacht.) Compare INTixe.

ĚX'TRA - ĂX'ǏLLĀRY̆, situated out of the axil.

ĔX'TRA-ÇĚL'LŨLAK, outside of a cell.

ĚX'TRA்-FŌLǏ̃ 'CEOŬS, not situated upon or near the leaves, as extru-foliuceous prickles.

ĚXTRÁV̆́G'ǏNAL, applied to branches in grasses which in growth burst through the base of the subtending sheath. Compare Intravaginal.

EXTRôRSE', applied to anthers the lobes of which are situated on the outside of the filament or connective, i.e, on the side farthest removed from the pistil. Such anthers generally dehisce on the outside also.

ĚXUัNGGUัC'ŪLĀTE, without an unguis or claw, as most petals.

$\breve{\mathbf{E X}} \overline{\mathbf{U}}^{\prime} \mathbf{V} \breve{\bar{A}} \overline{\mathrm{E}}$, anything excreted or cast off. (Rare.)

EX̄E (Hort.), a bud on a tuber; the cavity enclosed by the callyx in the apple; the ostiolum or opening in the apex of a tig: any conspicuous central spot in a flower or petal, including the disk in Compositæ.

FACE, the upper, imuer, or free surface of an organ as opposed to the back.

$\mathbf{F} \overline{\mathbf{A}}^{\prime} \mathbf{C I} \overline{\mathbf{E}} \mathbf{S}$, the general aspect of a plant. (Obs.) Com pare HABIT. 
FĂC'ULTĀTǏVE， occasiona\}; incidental. Compare Unligate.

FĂC'ULTĀTǏVE PĂR'ȦSĪTE, a plant (usually a stuporophytic fungus) capable of passing through at least certain stages of its (levelopment as a parasite, but which does not always or necessarily do so.

FĂC'ULTĀTİVE SĂP' RŌPHĪTE, a prant (usually applied to parasitic ftugi) which is capable of living as a saprophyte during the whole or a part of its life.

F $\breve{A C} C^{\prime} \overline{U L A} \dot{A}$, see FECULA.

FĂL'CĀTE, scythe-sliaped, or sickle-shaped. Compare UNCrNATE.

FĂL'C̣IFÔRM, see FALCATE.

FALSE, similar in appearauce, but different in structure or origin; spurious. The same as the Greek pseudo-.

FALSE DĪ€HǑT' $T^{\prime} \mathbf{M} \check{Y}$, any dichotomous appearance which does not arise from a terminal division of the main axis, as a dichasium.

FẠLSE DǏSSĚP'ǏMENT, one of the additional partitions in certain fruits which is not formed by the edges of carpels. False dissepiments frequently proceed from the dorsal suture.

FALSE İNDƯSTIUัM, a recurved margin of the froud in ferus covering the sporangia, as in the geuus Pteris.

FALLSE RẢCĒME', see HELICOID CYule.

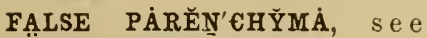
PseudoparexchyM.

FĂM'ÍL $\breve{Y}$, the same as ORDER, which see, and in more familial use. The term is also employed, especially among cryptugams, to indicate groups lower than the order. In hor- ticulture it is sometimes used to indicate groups of related varieties, as the Duchess family amoug apples.

FĂN'-SHĀPED, like a fan in outline, especially if also plaited; Habelliform; Habellate.

FĂN'-VEINED, see PAlahtely. VEINED.

FÄRC'TĀTE, wilhout vacuities; stuffed; olstructed; infarctate; infareterl; opposed especially to fistulose. Seldom used, the word solirl or turgid being nearly always preferable. See STUFFED.

FÁRI'NÁ, starch. Formerly applied also to pollen.

FĂRĬNĀ'C̣EOǓs, containing starch, or of the texture of meat or flour.

FĂR' ǏNŌSE, covered with a white mealy powder.

FĂR'ǏNōSE, u., a supposititious cellulose substance in starclıgruins, which is not colored blue by iodiue. Compare Granulose.

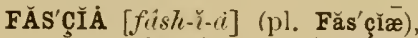
a cross-band, especially of color. (Rare.)

FĂS'ÇĪĀTĚD, (1) having broad parallel bands or stripes; (2) exhibitiug fasciation, which see.

FĂSÇĪÁt'TION, a monstrous flattener expansion of the stem, as in the garden cockscomb (Celosia).

FĂS'ÇICLE, a bundle, as the clustered leaves on the dormant branches or spurs of the larch: a bunclle of tuberous roots, as in the dahlia; a tibrovascular buudle, especially if rudimentary; a close cyme, as in sweet-william; a bundle of herbarium specimens. 
FĂS'ÇICLED, growing in tufts or clusters; fascicular; fasciculated.

FĂSÇĬC'ŪLAR, see FASCICLED.

FĂSÇĬC'ÜLAR SY̌S'TĚM, s e e Fibrovascular Srsteir.

FĂSÇĬC'T̄LAR TǏs'SÜE, see FItrROYASCULAR T'ISSUE.

FĂSÇǏ C'ŨLĀTE, see FAsCICLED.

FĂSÇĬC'ŪLĀTĚD, see FASCICLED. FĂSÇĬC'ŪLŬS (pl. Fáscǐc'ǔlī), a dense cymose inflorescence, as in sweet-william; fascicle.

FĂsTĬG'ĪĀTE, having $\mathrm{t}$ he branches close, parallel, and upright, as in Lombardy poplar. Sometimes erroneously used for Hlat-topped.

FẠUX (pl. Fạu'çēs), the throat or oritice of a gamopetalous or gamosepalous flower.

FẢVĚL'LA் (pl. Fảvél'læ), a form of sporocarp in Floridea, consisting of an irregular mass of spores embedded in more or less gelatinous material aud without a distinct conceptacle. It may be seated upon the frond or more or less embedded in it, and is derived from one or from several coutiguous cells. In the latter case, and also when embedded in the froud, it was formerly called a favellidium.

FẢ $\overline{\mathbf{E}}^{\prime} \overline{\mathbf{O}} \mathrm{L} \overline{\mathrm{A}} \mathrm{TE}$, see Alveolate.

FẢVŌSE', see AlVEOLATE.

F̌̌ATH'ẼR-VEINED, see PINNATELY-VEINED.

FĚATH'ẼRY̌, see Plumose.

F̌̌́'ǓLA, any powdery fariuaceous matter.

FĚC'ŪLENT, muddy; thick with sediment.

FĚCŬNDĀ'TION, see FERTILIZATION.

FĒCŬN'DITYY, fertility; fruitfulness.
FEED'ẼR, an outgrowth of the hypocotyl in the embryo of some genera of Gnetacex which serves for the absorp$t$ ion of the endosperm.

FĚLT'ĚD-TǏS'SÜE, lyphal tissue in which the filamentous cells are not regularly united, as in phenogams, but cross one another irregularly, and are often more or less grown together; tela contexta; spurious tissue. In its more consolidated forms it is known as pseudo-pirenchyma.

FE' $\mathbf{M A L E}$ FLOWẼ R, one having pistils only; pistillate flower.

FĒNĚS'TRĀTE, having rather large openings like wiudows.

FE'RAL, see WILD.

FĚRRỤ'GIN OǓs, resembling ironrust; brownish - red. For synonyms see Rubiginose.

FẼR'TǏLE, producing fruit, or reproductive bodies of auy kind; having pistillate or perfect flowers.

FẼRTILIZİ'TION, the process by which the pollen causes the ovule to develop as a seed. It is the essential feature of sexual reproduction of every kind, being the union of the male ancl female reproductive bodies. In some cases, and perhatps always, it consists in the coalescence of the nuclei of two cells of different nature and origin; fecundation; impregnation. Sec ConsugaTION.

FEÜ'ILLEMÔRT, of the color of a faded leaf: filemot. (Rare.)

FI'BER, see FiBre.

FI'BR $\tilde{E}$, any slender thread-like body of considerable strength; especially: (1) the slender fusiform cells of the inver bark, kuown as bast; (2) small slen- 
der roots like those of grasses. Also applied to bodies of simi. lar form which have no special strength, as the threads or filaments in a nucleus during celldivision.

FI'BRIL, diminutive of Fibre; a small or secondary tibre.

FĪBRĬL'LA (pl. Fībrìl'læ), see Fibril.

F'́'BRILLŌSE, diminutive of Fibrous; bearing tibrils or composed of small fibres.

FI'BRĬLLŌSE MȲCE'LǏŬM, see Fibrods Mrcelium.

Fi'́BRoŬs, composed wholly, or in large part, of fibres; separable into tibres.

F'̄'BROǓS MỸCE'L lium in which the hyphæ form by their union elongated branching strands; fibrillose mycelium; mycelial strand.

F'̄'BRŌ-VA'SAL BŬN'DLE, see Fibirovascular Bundle.

F'̈'BR0̄-VA'SAL STRĬNG, see Fibrovascular BUNdLe.

FİBRŌVĂS'CŪLAR BƯN'DLE, one of the characteristic elements in the stem of all flowering plants and the higher cryptogams. Isolated tibrovascular bundles form the "fibres" in the so-called pith of a cornstalk, and the veins in leaves. Each bundle usually consists of two parts, xylem and phloem (which see), the whole often surromnded by a special layer of cells called the bundlesheath.

FİBRōVĂS'CŪLAR CôRD, a term applied by Strasburger to a fibrovascular bundle in monocotyledons, but not generally adopted.

FİBRŌVĂS'CŪLAR CY̌L'ǏNDẼR, a name giveu to the peculiar fibrovascular system in the stem of Lycopodiacex. Sometimes used in exogens, especially in roots, where it is generally called "central cylinder."

FĪBRŌVĂS'CŬLAR SY̌S'TĚM, the fibrovascular tissues of a plant taken together. In exogenous trees it includes the veius of the leaves, and all the material of the stem and branches, except the pith, medullary rays, and outer bark.

FĬD'DLE-SHĀPED, see PANDURIFORM.

FǏL'ȦMENT, the stalk of a stamen supporting the anther.

FǏLAMĔN'TOǓS, slender and thread-like, or composed of filaments.

FILLA்M ĚN'TOǓS MȲCE'L ǏŬM, one composed of free hyphæ, which are at most loosely interwoven with one another, but without forming bodies of definite shapeand outline; Hoccose mycelium.

FǏLAMMĚN'TOǓS SPÖR'ŌPHŌRE, SEe SIMPLE SPOROPHORE.

FǏLA'RĨOǓS, see FILAMENTOES.

FǏL'ẼMŏT, see FEUILLEMolRT.

FǏL'ǏCōID, fern-like.

FǏL'ǏFôRM, threıd-shaped; slender, romnd, and of equal thickness throughout. Compare CaPILlarT.

FǏL'ǏFôRM ĂPPẢRA'TŬS, a homogeneous, strongly refractive, cellulose cap often found at the apex of each synergida, especially in monocotyleclons.

FǏLǏĚN'DŪLOǓs, hanging by a thread.

F $\bar{I}^{\prime} \mathbf{L} \bar{S} \mathbf{S E}$, termiuating in a threadlike process.

FǏM'BRİ̀, a fringe. 
FǏM'BRǏĀTE, fringed; bordered by lax, slender processes, generully larger thin hairs.

FǏM'BRǏCĀTE, sec FıMBRIATE.

FĬMBRĬL'LĀTE, diminutive of Fimbriate; havinga very smal] or tine fringe; fimbrilliferous.

FĬMBRĬLLIF'ẼROǓS, see FrMBRIL],ATE.

FǏN'GẼRED, see DifrTATE.

FǏS'SǏLE, capable of being split or divided.

FǏs SION, the division of an organ which is usually entire; that mode of cell-division in which the cell separates into two nearly equal portions.

FǏSSǏP ȦROǓs, reproducing by spontaneous division into two parts.

FÍs'TŪLAR, see Fistulose.

FǏs TÜLǏFôRM, tubulatr.

FǏS'TŪLōSE, hollow and cyliudrieal, or nearly so, as the stemis of many grisses: fistular; fistulous. Used especitlly when the hollow is of consiclerable size, as in reerls.

FǏS'TŨLOǓs, see FISTCLOSE.

FLABĚLL'LĀTE, see FAN-SHAPED.

FLÄBĔL'LǏFôRM, see FANSIIAPED.

FLĂC'C̆́D, mable to support its own weight. Compare Lax.

FLĂǦ̌L'LÄ, pl, see FIAGELI.UNI.

FLĂG'ELLȦR̆̌, pertaining to or cansed by flagella, as the flagelinry movements of certuin zoöspores.

FLĂG'ĔLLĀTE, (1) bearing tlagella; (2) flagelliform.

FLÁGĔL'LǏFôRM, lonğ a u d supple like a whip-lash; tlageltate.

FLÁĞĚL'LÜM (pl. Flăğèl'lá), any slender flexible process or organ, as (1) a solitary long swinging process of protoplasm on certain zoöspores (a large cilium); (2) a similar appendage to the cells of many bacteria: (3) a young flexible shoot, especially a long trailing brauch of a vine (sarment).

FLĂT (Hort.), in describing fruits, means flattened endwise (itepressed).

FLA் V̌̌s'ÇENT, yellowish.

FLÄ'VOǓS, sce FLAYUS.

FL $\bar{A}^{\prime}$ VUSs, pure pale yellow; lemon-5ellow. Compare LUTEUS.

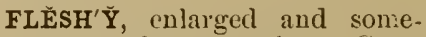
what soft, as a tuber. Compare Succulent.

FLĚX'ŪōSE, zigzagr; wavy; winding; tlexuous.

FLĚX'ŪOǓS, see FLEXưosE.

FLŌAT'ǏNG, see NATANT.

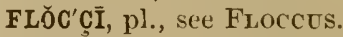

FLǒccōsE', covered with matted woolly hairs, especially if they fall away in tufts. Said of the perithecia of Erysiphe when the appendages are of equal cliameter throughout, more or less tortuous, and end abruptly, or in a straight point thus distinguished from "hooked" and "dichotomous)."

FLǑCCŌSE' M M $\bar{Y} C \bar{E}^{\prime} \mathbf{L} \breve{I} \mathbf{M}$, see Filanientrot's Mrcelium.

FLǑC'CŪLEN', see Floccose.

FLŏC'CǓs (pl. Flǒc'çī), any woolly hair or thread, or a tuft of such filaments.

FLō'RA, the agriegate of the species of plants of a country or region, or a book which describes them.

FLō'RAL, pertaining to a flower. 
FLŌ'RAL DI'ẢGRĂM, a drawing showing the relative position of the parts of a flower.

FLŌ'RAL ĚN'VĚLŌPES, in ordinary plants the calyx and corolla, sometimes including bracts when developed in il special manner so as to surround a flower: in crasses the flowering glume and palet.

FLŌ'RAL GLŪME, used by Dr. IV. J. Beal instead of tlowering glume or lower palet.

FLO' RAL LẼAF, see BRAC'T.

FLORĚS'CENCCE, the opening of flowers; blossoming; anthesis.

FLŌ'RĔT, an individual Hower of a bead or cluster, especially in Compositæ: Hoscule; Hosculus; floweret.

FLŌRǏ $F^{\prime} \tilde{E} R 0 U ั S$, flower-bearing.

FLŌRĬP'ÁROŬS, Horiferous; sometimes used when a proliferous branch or Hower bears additional flowers instead of stems and leaves.

FLǑS'CŬLAR, see Flosculous.

FLǑS'CŪLE, see FLORET.

FLǑS'CŪLŌSE, see FLOSCULOUS.

FLǑS'CÜLOŬS, composed of or bearing Horets: applied mainly to heads of Howers in Composita when composed of tubular Horets only. Compare SEMIFLOSCULOUS.

FLOW' $\tilde{\mathbf{E}} \boldsymbol{R}$, the part of a plant immediately concerned in the production of seed. A complete flower in ordinary plauts consists of pistils, stamens, corolla, and calyx, of which the two former are essential to the production of seed. The parts of a Hower are modified leaves.

FLOW'ẼR-BŬD, an unopened Hower or cluster of Howers.

FLOW ẼRĚT, see FLORET.
FLOW'ẼR-HẼAD, see HEAD.

FLOW'ẼRING GLŪME, the organ in grasses formerly called the lower palet. It may subtend one flower or more. Dr. WV. J. Beal proposes the more appropriate term Floral Glume.

FLU $\bar{U}^{\prime}$ I TANT, floating in or upon water. Compare Natast.

FLÜ'VĬAL, see FLCVIATIC.

FLŪVǏ̆T'ǏC, belonging to How. ing water; fluvial; fluviatile.

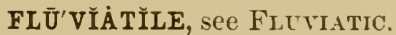

FōLD'ED, (1) said of leaves in vernation when the two halves are simply brought together forward: (2) (Hort.) when a narrow projection of the thesh of an apple extends into the cavity. (Warder.) Compare LIPPED.

FōLǏÁ'ÇEOǓS, leaf-like; having leaves intermixed with the flowers, is a foliaceous spike; consisting of thin laminæ or layers; foliose.

FŌLǏÁ'ÇEOǓS THĂL'LŬS, the thallus in licheus when tlat and leaf-like and attached by one or few points; frondose thallus. Compare CrustaCEOUS ThaLlu's.

Fō'L İÁGE LẼAVES, ordinary green leares, in distinction from those which are trans. formed into petals, scales, etc.

Fo'́l'L AR-TRĀÇE, see L EA F TRACE.

FōL Ĭ $\bar{A}^{\prime}$ TION, the act of leafing out; frondescence. Sometimes used erroneously for prefoliation.

FŌLIF' ẼROǓS, bearing or producing leaves; folififerous: foliiparous.

FōLIǏF' ẼROǓs, see FoLIFEloUs. Fō'L Ǐ́FôRM, leaf-shaped 
FōLIǏP'ÁROǓS, producing leaves or leizves ouly.

Fō'LĪōLĀTE, pertaining to leaf. lets, as trifoliolate-having three leaflets.

Fō'L ǏōLE, a little leaf or leaflet. (Rare.)

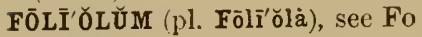
LIOLE.

Fo'LĪōsE, (1) abounding in leaves; foliaceous; leafy ; (2) having the nature or appearance of a leaf.

Fō'LǏOǓs, see Foliose.

Fō'LǏŬM (pl. Fō'lỉà), a leaf.

FŏL'LICLE, a simple pod opening by the ventral suture only, as in the milkweed (Asclepias).

FŏLLĬC' ŪLĀTE, having follicles. FǒLLIC' ŪLŬS, see FolLICLE.

FOOT, a basal protrusion of the fern-plant which maintains its connection with the prothallus. Also a similar base to the seta in mosses.

FOOT-STALK, the stem of a leaf, Hower, or other organ. See Petiole, Peduncle, Pedi. CEL, STIPE.

FōRA' $\bar{A}^{\prime} \mathbf{E} \mathbf{N}$ (pl. Fōrăm'inà), any suluall aperture, especially that in the integuments of the ovule, at which fertilization is effected. Compare MichopyLE.

FōRĂM'ǏNĀTĚD, having small holes or perforations. Compare LACUNOSE.

FōRÁMǏN'ŨLŌSE, pierced with very small holes; diminutive of Foraminated.

FôR'ÇĬPĀTE, like a pair of pincers.

FôRKED, having two or more main branches arising from nearly the same point; furcate. Compare Bifurcated.

FôRM, (1) nearly the same as Variation, which see; (2) one of the conditions or states wheu several regularly appear among plants of the same parentage, as the short-styled form in heterostyled species.

FôRM'ÁTǏVE, concerned with or serving for growth, as formative materiai (starch, albuminoids, etc.), formative tissue (meristem).

FôRM-GE' NŬS, a so-called genus constitited by similar form. species, as Botrytis in fungi; psenclo-gemus.

FÔRM-SPE' $\bar{E}^{\prime} \mathbf{I E} S$, a particular phase in the development of a protean organism, as the rusts; so called because the different stages have of ten been mistaken for distiuct species. Used also by E. L. Stmrtevant synonymously with Race.

FôRM-SPŌRE, a body which is morphologically or physiologically a spore, but which either does not become detached as an orlinary spore for dispersion, or which las not the power of germination.

FÔR'NǏCĀTE, see VAULTED.

FôR'NIXX (pl. Fôr'nicēş), arclied scales in the throat of a corolla, as in comfrey.

Fŏs'ŠL BǑT'Á fossil plants, including their order of succession on the earth; paleobotany; paleopliytology; geological botany; phytolithology.

FǑS'TẼR-PLĂNT, see HosT.

FOUR-FŌLD PǑL'LĚN - GRĀIN, see Pollen-tetrad.

$\mathbf{F} \overline{0}^{\prime} \mathbf{V} \overline{\mathbf{A}} \mathbf{A}\left(\mathrm{pl}, \mathbf{F o ̄}^{\prime} \mathbf{v e ̄}\right)$, al pit or depression, as that in the leaf of Isoetes, coutaining the sporangium.

F $\bar{O}^{\prime} \mathbf{V} \overline{\mathrm{E}} \overline{\mathrm{A}} \mathrm{TE}$, marked with deep or rather large pits or depressions. Compare Alveolate. 
FōVĒ'ōLA் (pl. Fōvē'ōlæ), a little pit or depression; diminutive of Fovea.

$\mathbf{F} \bar{O}^{\prime} \mathbf{V} \overline{\mathbf{E}} \mathbf{O} \mathbf{L} \overline{\mathbf{T}} \mathbf{E}$, marked with little pits or depressions.

FōvĭL'LA் (pl. Fōvĭl'læ), the con tents of a pollen-grain; geuerally used in the singular for the entire contents, but sometimes applied to the individual granules in the fluid protoplasm.

FREE, not united with any dissimilar part; opposed to Ad. berent. Compare Distisct.

FREE ÇĔLL-FôRM $\bar{A}^{\prime} T I O N$, the production of new cells within another, generally free from the cell-wall of the original or mother cell. Usually applied to cases in which several nuclei appear within the cell, each of wlich becomes surrounded by an inclependent cell-wall, as in the production of pollen; in. ternal or endogenous cell-for. mation.

FREE GRŌW'ǏNG, thrifty or vig. orous, as opposed to dwarf or feeble.

FREE-STǑCK, a seedling tree of the same species used for grafting, as opposed to a stock of a rlifferent species, the latter being generally used for dwarfing.

FREE'STŌNE, applied to drupes in which the Hesh separates readily from the pit when ripe. Compare Clingstone.

FRĬLL, see ARMILLA.

FRǏNGED, see FIMBııAte.

FRŏND, the leaf in ferns, especially the foliage portion of it: the expancled leaf-like portion of the thallus of liverworts; the stem and leaves taken together in plants where the distinction between leaf and stem is not obvious, or where, as in Equisetum, the leaves are unimportant; the whole expanded leaf-like or branchiug thallus of many marine algae.

FRǑNDĚS'ÇENÇE, see FOLIATION and PHyLlody.

FRŎN'DǏFÔRM, frond-like or froud-shaped, especially like the leaves of ordinary ferns.

FRŏN'DŌSE, froud-like, or producing fronds instead of ordi. dary foliage; leafy or leat.like. (Rare.) Compare Tilalloid.

FRŎN'DŌSE THĂL'LŬS, see FoLIACEOUS Thallus.

FRŎTH'Y, see WARTY.

FRŬCTĔS'ÇENÇE, the time at which a fruit arrives at maturity.

FRŬCTǏFǏCA'TION, the fruit and attendant parts; an infloresceuce at any stage of growth; the process of development of a fruit and its attendant parts.

FRŬCTǏFǏCA'TION, ÔR'GANS OF, stamens and pistils.

FRUIT, the mature ovary and its contents, together with iny closely adheriug part; specialized reproductive bodies of auy kind, as the spores of cryptogams, including any modified portion of the plant in which they are produced. The term is also extended to many consolidated forms of intlorescence, as the cone of the pine.

FRƯIT'-BŬD, generally the same as Flower-bud, which see.

FRƯIT'-DǑT, see Sorús

FRỤIT'SPÛR, a short stout branch. bearing ve or more flower-buds, as in the apple.

FRƯMĚNT $\bar{A}^{\prime}$ ÇEOǓS, producing or pertaining to elible graiu.

FRŬS'TÛLE, the individual in Diatomacere (often joived together in colonies). 
FRŬS'TŪLŌSE, consisting of similar separable parts, like the frustules of diatoms.

FRUT ŤS'CENT, somewhat shrubby,-woody at the base and herbaceous above, like the gar. den sage; subfrutescent; suffrutescent.

FRƯ'TĚX, a slırub, which see.

FRỰ'TǏCōSE, shrubby; pertaining to shrubs; shrub-like. Compare Frutescent.

FRƯ'TǏCŌSE THĂL'LŬS, a thallus in lichens which is attached to the substratum by one point only. or by a narrow base, aud grows mpward as a simple, or more usually branched, shrublike body.

FRƯTÍC'ŪLÖSE, like a small shrub; diminutive of Fruticose.

FRƯTIC'C'ULŬS, a little shrub.

FU'C $\overline{O I D}$, pertaining to, or resembling, Fucus, a genus of marine alsae.

FŪG $\bar{A}^{\prime} C I O U ̌ S$, disappearing in a very slort time; eplemeral. Compare Caducous.

FŨ'GÍTǏve, quickly disappearing; easily blown away or absorbed; volatile; evanescent; fug:tcious.

FŬL'CRĀTE, furnished with fulcra, which see.

FŬL'CRŬM (pl. Fŭl'crà), a general term for various appendages to the plant which serve for support or defence, as ten(lrils, spines, prickles, hairs, etc. Now little used.

FŪLǏG'ǏNōsE, see Fuliginous.

FÜLĬ'́'INOǓS, dark brown; sooty or smoky.

FULL, applied to double flowers in which all the stamens and pistils are transformed into petals: completely double.

FŬL'VǏD, see Fulvous.
FǓL'Voǔs, yellow, mixed with gray and brown; tawny.

FUัL'VǓS, see FuLvous.

F $\bar{U}^{\prime} \mathbf{M} \overline{\text { SSE}}$, smoke-colored; brownish gray.

FŨ'MOǓs, see Fumose.

FǓNDAMM̌̃' TAL ÔR'GANS, root, stem, and leaf.

FŬNDÁMĚN'TAL SY̌S'TĔM, all that portion of the substance of the higher plants which is not inclucled in the fibrorascular and epidermal srstems. Compare Cellular Srstey.

FǓNDÄMĚN'TAL TǏS'SŪE, pith, cortex, and medullary rays; grouncl-tissue.

FǓNGÍCI'DAL, destructive to fungi; antimycotic.

FǓN'ĞCĨDE, anythiug destructive to the life of a fungus.

FǓN'GÍFÔRM, mushroom-slıiped. FŬNGĞL'LIFÔRM, diminutive of Fuvgiform.

FǓN'GOID, fungus-like.

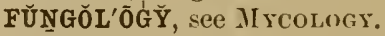

FƯ $\mathbf{N}^{\prime} \mathbf{G} \bar{O} \mathbf{S E}$, spongy in texture, like many fungi.

FŬN'GOǓS, prouluced by a fungus; pertaining to a fungus or 10 fungi, as a fungous disease. The substantive form "Fungus" is also used as an adjec. tive.

FUัN'GǓSED, injured by a fungus. (Rare.)

FU'NǏCLF, see FuNiculus.

FŪNǏC'ŬLAR CôRD, see FuxICULUs.

FŪNÍC'ŪLǓs, the stalk of an ovile or seed by which it is attached to the placenta; funicular corl; umbilical cord; poclosperm. In Nidularize a hyphal cord attaching the peridiolum to the inner surface of the wall of the peridium. 
FŪNĬL'ǏFôRM, like a rope or cord, as the roots of many eudogens.

FŬN'NĚL-FôRM, tubular, and gradually enlarging upward to a spreadiug border; infundibuliform. Compare Rotate and Cyatiliforis.

FÛR'CĀTE, see For KED.

FÛR'CÄTĚD, see ForkED.

FÛRCA'TION, division into two (mely said of more) maiu branches. See Bifuncation.

FÛRFÜRA' $\bar{A}^{\prime}$ CEOǓs, covered witl soft scilles easily displaced; scurfy.

FǓR'RŌWED, see SULCATE.

FǓSÇĚS'ÇENT, sliglıtly fuscous.

FǓs'COǓS, grayish browu.

FÜ'SǏFôRM, spindle-shaped; enlargen, terete, and taperiug toward each end, as the roots of some ridlishes.

FU' $\bar{U}^{\prime} \mathbf{S O I D}$, somewhat fusiform.

GĂL'BŪLǓs, a closed fleshy cone, resembling a berry, as that of juniper.

$\mathbf{G} \overline{\mathbf{A}}^{\prime} \mathbf{L} \overline{\mathbf{E}} \dot{\mathbf{A}}$, an arched sepal or petal resembliug il helmet; belmet; lood; cucillus. Also applied to the upper lip of some sicrophulariaces, though not so arched.

$\mathbf{G} \overline{\mathbf{A}}^{\prime} \mathbf{L} \overline{\mathbf{E}} \mathbf{A} T \mathbf{E}$, lıelmet-shaped, as the Hower of Aconitum.

GÁLVÅNǑT'RōPǏsM, the curvature of growing orgaus under the influence of a current of electricity.

GĂM'ÉTE, any sexual protoplasmic boly, naked or invested with a membrane, motile or non-motile, as au oösphere or antherozoid; conjugation-cell; renerative cell. Used mainly in Conjugatæ.
GĂMĚTÖĞLN'ẼSIS, the production of gametes (malc or female).

GĂM' $\mathbf{E} T \mathbf{O} P H \bar{Y} T E$, the protlatlus or sexual generation in ferus, etc. Compare Sporophrte.

GĂMōǴĚN'ẼSIS, sexual reproduction.

GĂMŌPĚT'ALOǓS, having the petals more or less united; sympetalous. Also called erroneously Mouopetalous. Compare Polypetalots and UNiPETALOUS.

GĂMŌPHY̌L'LOǓS, a ter'm including Gamopelalous and Gamosepalous, but applied mainly to sepals.

GĂMōsĚP'ALOǓs, lıving sepals more or less united; monosepalous.

GĂN'GLǏ̃oN (pl. Găn'glià), a term applied to various enlargements on the mycelium of certain fungi, some of which at least are rudimentary fructifications.

ǴEITŌNǒG'ÁMY̌, the fertilization of a pistil by pollen from another flower of the sime plant-the closest kind of crossfertilization.

ǴĔM, see GEMMA.

ĠĔM'ǏNĀTE, in pairs or twins; binate.

ǴĔM MÁ (p). Gěm'mæ', an olıl term for leaf-bud, now usually confined to varions asexual reproductive bud-like processes in cryptogams. Ther may be distinguished from renirlia W not laving as miform methods of production, by greater variation in size, aud by usually containing many cells. See Goxidiuy.

GEMMA'C ÁEOǓS, having the nature of gemmx; bealing gemmæ; gemmiferous. 
ǴEMMÁ'TION, reproduction by means of gemme.

GEMMMǏF'EROǓS, bearing gemmæ.

GĔMMǏP'ȦROǓs, p r odu cing gemmæ.

GEัM'MÚLE, diminutive of Gemma-an old term for leafbud and plumule. Now applied to certain primary formative grauules in the protoplasm. (Nägeli.)

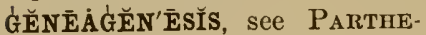
NOGENESIS.

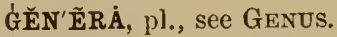

ǴĔ'ẼRAL, see CoMMON.

GÉN'ẼRAL ǏN'VŌLŪCRE, see COMMON INVOLUCRE.

ǴĚN'ẼRĀTĨNG TǏS'SŪE, see Meristem.

ǴĔN'ẼRĀTIVE ČLLL, a sexual reproductive ecll of any kind. See Gainete. Also applied to the cell in a pollen-grain which develops into the pollen-tube. Compare Vegetative Celd.

GĚN'ẼRĀTIVVE NU'CLẼŬS, the uncleus in the pollen-tube which is directly concerned iu fertilization.

G'ẼNĚR'

ǴENĚT'IC, pertaining to geueration or origin; e.g., things are genetically related which have the same origin.

G'ENNĚT' ǏC SPI'RAL, a spiral line passing through the point of insertion of all equivaleut lateral members on an axis from older to younger; generating spirul; fundamental spiral.

ǴEN ǏC' $\bar{U} L \bar{A} T E$, bent abruptly at an angle, like the knee, as the stems of decumbent grasses.

ǴĒNǏC'ŪLŬM, a term occasionally applied to a node, especially when the stem is bent at that point, as is frequent in grasses.
GÉNUTFLĚC'TION, the formation of a knee-like bend in a conjugating filament, as is Sirogonium.

G'E' $\bar{E}^{\prime} \mathrm{N}$ S (pl, Gén'ērà), a group of species within a family or order.

GË'NǓS-HȲ'BRID, a hybrid between plants of distinct genera; bigener.

G'É $\mathbf{0} B L A \dot{S} T$, a plumule which in germination leaves the cotyledous under ground, as in the pea.

G'ĒōGRĂPH' ǏCAL BǑT'ÁN Ý, the study of plants in respect to their geographical distribution; botanical geograpby.

ǴĒōLŐ' '́C̆CAL BŏT'ÁNY̌, see Fos SIL BotaNy.

GÉ̄̆T'RŌPǏsM, the tendency to grow downward or toward the centre of the earth. Compare APOGEOTROPISM.

GẼRM, a bud or growing point; the embryo in is seed; a rudimentary ovary or young fruit; a female reproductive cellgerm-cell, oösphere; a spore or seed; especially a spore or reproductive individual in bacteria.

ǴERM-ČELL, any female reproductive cell. (ompare SPERMCell. See Oösphere. Applied also by Brefeld to spores of the simplest character (Sporidia) borue on a promycelium.

G $\tilde{E} \mathbf{R}^{\prime} \mathbf{M} \breve{E} \mathbf{N}$, an old name for ovary.

GẼER'MǏNAL ĂPPÁRÁ'TŬS, see EGg-APPARATUS.

G'ẼR'MǏNAL CôR'PǓSÇLE, SEe OösPHERE.

G'ẼR'MǏNAL VĚS'ǏCLE, s e e OöSPHERE.

GẼRMINNA'TION, the early stage of growth of a seed or spore into a new plant; sproutiug. 
ǴĔR'MǏNĀTǏVE NŪ'CLẼUS, see Generative Nucleus.

GẼ RM - N $\bar{U}^{\prime} C L \bar{E} U \mathbf{S}$, the mucleus resulting from the union of the pronuclei of two gametes in conjugation or fertilization.

GẼRM-PŌRE, a pit in the coat of a spore through which the gerno-tube issues in germination.

ǴẼRM-TŪBE, the first growtlı from a spore or sclerotium upon germination.

GÍB'BOǓS, convex, as though swollen; protuberant, especially upon one sicle, or some distinct part of the surface.

GILLLS, the spore-bearing plates upon the lower side of the cap in mushroous; lamellie.

GIR'DLE, the overlapping edge of one of the two valves in diatoms.

GLA'BRÃTE, nearly glabrous.

GLẢBRĚS'ÇENT, slightly glabrous.

GLĂBRǏǓS'CŪLǓS, almost but not quite glabrous.

GL $\bar{A}^{\prime} B R O U ̌ S$, sinooth; free from roughness or hairs-the surface may be uneven. Compare Scabrods and Lavis.

GLĂD' ĪĀTE, see ENsiforM.

GLAND, any secretiug apparatus. A gland is generally a group of cells luaving a peculiar form and character to adapt them to their special function. 'They sometimes form wart-like projections upon the surface, or depressions within it. The hairs of many plints also serve as glands (see GiandULAk HAIR). In deeply - seated glands of certain kinds, as those of the pine, the internal cell-walls of the gland are more or less absorbed to form reservoirs for the secreted sub- stance. The term gland is also applied to certain wart-like swellings which are not secre1ory, as the abortive tecth at the base of the leaf in the peach and cherry.

GLĂN'DǏFôRM, gland-shaped or gland-like; adenoid.

GLAND OF THE TORUS, see LEPAL.

GLĂN'DŪLAR, glaud-like or bear. ing glands; glanrluliferous.

GLĂN'DŪLAR DǏSK, see RETINACUI,UI.

GLĂN'DŪLAR HÂIR, an epidermal appendage of oue or more cells, the apex of which is usually enlarged and coutains the peculiar secretion.

GLĂN'DŨLAR WOŌD' TǏS'SŪE, a term formerly applied to the wooly tissue of Conifere from the appearance of its circular bordered pits.

GLĂN'DÜL $\bar{A}^{\prime} T I O N$, the position and arrangement of the glands upon a plint.

GLĂNDŪLĪF'ĚROǓs, b e a $\mathrm{r}$ i n $\mathrm{g}$ glands.

GLĂN'DŪLŌSE, see GIANDULAR. GLĂN'DŪLŌSE-Š̌R'RĀTE, haVing serratures tipped by socalled glands, as the leaves of Prunus glandulosa.

GLǍNS, a nut like that of the oak and chestmut, and sometimes extended to all linge nuts. A term of little use.

GLÂR' ĒōSE, growing in gravelly places.

GLẠUÇES'ÇENT, slightly glaucous.

GLACU'COǓS, covered with a whitish bloom, as the leaves of cabbage; more accurately, light blıish green; sea-green. Compare Pruinose, Hoarr, and CANESCENT. 
GLE' $\overline{\mathbf{E}}^{\prime} \mathbf{B} \dot{\mathbf{A}}$ (j)l. Glē'bæ), chambered sporogenous tissue within a sporophore, as in puff-balls.

GLō'BĀTE, globular.

GLO'BOIDS, granules of calciummaguesium phosplate found in graius of aleurone.

GLón'BōSE, see GLoBULAR.

GLŎB'ÜLAR, spherical or nearly so; globose.

GLŐ' $\mathbf{B}^{\prime} \mathbf{L E}$, the autheridium or male organ of Characeæ.

GLŌEHǏD'Ǐ $\bar{A} T E$, barbed like an arrow or tish-book.

GLŌ'€HǏs, a barbed hair or bristle.

GLŌM'ẼRĀTE, collected into a close round heud.

GLǑM'ẼRŪLE, a capitate cyme.

GLÜ'MÁ, see GLUME.

GLŪMA'CEOǓS, bearing or resembling glumes.

GLŪME, one of the outer floral envelopes in grasses. The term as now used includes the bracts which subtend a spikelet (empty glumes) and the lower of the two bracts subtending the individual flower (Howering glume).

GLŪMĽL'LA, an obsolete term which lias been applied both to the palet and lodicule in grisses.

GLŪMĚL'LŪLÁ, see LODICULE.

GNAUR, a knot. (Obs.)

GNŌMǑN'ǏCAL, bent at right angles. (Olus.) See GenicuI.ATE.

GŎB'LĚT-SHĀPED, see CRATERIFORM.

GŌNǏD'ǏŌPHŌRE, a stalk bearing a gonidium.

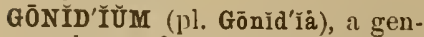
eral term for nearly all asexual reproductive bodies in cryptogams. Also applied to the algal host of lichens. Compare SPore and Carpospone.

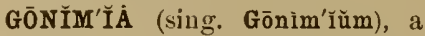
term of little importance originated by Nylander and used by Tuekerman and other's for pale bluish green gonidia in lichens.

GōNǏM' $\mathbf{I} C$ LĀYẼR, the gonidial layer in certain lichens. "Gonidial layer" is preferable.

GǑN'ǏMOǓS, gronidial as applied to the algal host of lichens; gouimic. (Rare.)

GǑN'ŌPHŌRE, a stalk elevating the stamens and pistils only.

G0̄NǑPH'0̄RŬM, see GoNOPHORE. GŏN'0̄PLĂȘM, in Peronosporeæ, the portion of the protoplasm of the antheridium which passes through the fertilizing tube and coalesces with the oösphere. (De Bary.)

GôRGE, see THroat.

GǑS'SY̌PǏNE, cottony.

GRĂÇ'ǏLE, slender.

GRÁFT - H $\bar{Y}^{\prime}$ BRILD, a plant, or portion of a plaut, which is supposed to lave been essentially modified through the influence of a graft.

GRĀIN, the seed or fruit of Graminex; any small seed.

GRĀINED, Laving grain - like tubercles or processes, as tliose on the flowers of doek (Rumex).

GRĂMǏN $\bar{A}^{\prime}$ ÇEOǓS, pertaiuing to grasses; gramineous.

GRAMIN'EAL, see GRAMINACEOUS.

GRẢMǏN'Ẽođ̌s, see GrAMINACEOUS.

GRĂMǏNǑL'ŌĞY, see AGROSTOLOGY.

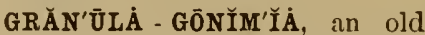
term for the gonidia of lichens. 
GRĂN'ULAR, composed of grains or granules; covered with small tubereles.

GRĂN'ŪLĀTE, see GRANULAR.

GRĂN'ŪLE, aly small grain-like body.

GRĀNULLIF'ẼROǓS, see GRANULAI.

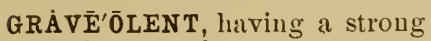
unpleasint odor.

GREEN-LÄYẼR, see M E s oPIILOEUM.

GRĒG $\bar{A}^{\prime}$ RIOǓs, thesame as Social; also ipplied to the fruiting spots or sori of a parasitic fungus when they appear in groups upon the host. Compire C'espitose.

GRŌSSIFǏCA'TION, the swelling of the ovary after ferlilization.

GROUND-TIS'SŪE, see FUNDA. IIENTAL TISSUE.

GRōW'ING POINT, see Punctum VEGETATIONIS.

GRōWTH-FôRM, a vegetable structure marked by some easily recognized feature of growth, chiracterizing stages in the lives of plants which are not necessarily closely related, as a filamentous fungus.

GRŌWTH' - RǏNG, see ANNUAL IRING.

GRỤMŌSE', see Grunous.

GRƯ'MOǓS, consisting of clustered grains or tubercles; grumose.

GUÄRD-ÇĚLLS, special epidermal cells, usually two in number, enclosing the opening of a stoma, and which have the power of altering their shape so as to increase or climinish the size of the opening.

GUÄRD'ǏAN-ÇĚLLS, see GUARDCELLS.

GU'́LAR, pertaining to the throat.
GŬM, a name applied to various viscid (not oily) secretions of amorphous eharacter which either dissolve in water or merely swell in it. as cerasin, the characteristic element of cherry gum.

GŬM-PĂS'SĀGE, a glandılar intercellular passage eontaining grim.

GUัS'SĔT, an intercellular space, either filled or loollow, at an angle where more than two cells meet.

GǓT'TĀTE, eovered with small dots, as though sprinkled with some colored fluid.

GŬT'TǏFẼR, a plant which produces gum or resiu.

GŬTTǏF'ẼRoǓs, yielding gum or resin.

GǓT'TŪLĀTE, resembling small drops of oil or resin.

GYYMNĂX'ŌNY̌, a monstrous condition in which the placenta protrudes from the ovary.

ǴY̌MNŌBLÀs'TƯs, having the ovary superior. (Obs.)

ǴY̌MNŌCÄR'POǓs, naked-fruited; having the fruit destitute of hairs (rare), or free from the perianth or other covering; in fungi, having the hymenium exposed when the spores are maturiug. Compare AxgroCARPOUS.

G'YMNŌSPẼR'MOǓS, having the seeds naked (not enclosed in a pericarp), as in Coniferie.

G'Y̌MNOS'TŌMOǓs, said of the mouth of the sporangium in mosses, when destitute of a peristome.

G'YM'NŌSPŌRE, a naked sporeone not produced in a receptacle.

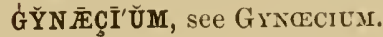


ĞYNĂN'DẼR, a plant liıving the stamens inserted on the pistil. (Rare.)

GY̌NĂND'RǏAN, see GYNANDROU's.

ǴY̌NĂND'RŌPHŌRE, a stalk supportiug the stimens and pistils above the insertion of the corolla: gonophore.

ǴY̌NĂNDRŎS'PŌROǓS, beariug both male and female spores; applied in Etogoniea to certain female plauts which pro. duce audmspores.

ĞYNĂN'DROǓS, having stamens and pistils united.

ĞY̌ĂN'THẼROǓS, having stamens converted into pistils.

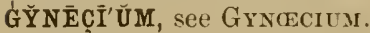

ǴY̌N'ŌBĀSE, an elevated portion of the receptacle supporting the ovary, as in geranium. Compare GrNophore.

GY̌NŌBĀ'SǏC, having a gryobase. Also applied to styles which are attached to the base instead of the summit of the ovary.

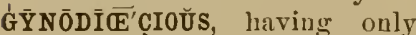
pistillate flowers on one set of plants and perfect flowers upon another set. Compare GrooMoxeEcIOUS and ANDrodicECIOUS.

G'Y̌NG'ČIU pistils of a flower taken togetber.

GỸNŌMŌNOE'CIOǓS, having perfect and pistillate flowers on the stume plant but no staminate flowers. Compare GrovDICECIOUS and ANDROMONEcrous.

GY̌N'ŌPHŌRE, the stalk of a pistil elevating it above the receptacle; carpophore; basigynium; podogynium; thecaphore. (Obs.) Compare Gynobase.

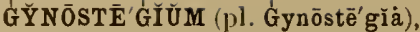
a sheath or covering of the gyuœcium, as the monadelphous filaments of Asclepias.

G'Y̌NOTTE'MǏŬM, a term former]y used for the united stamens and style (column) in orchicls.

G' $\bar{Y}^{\prime} \mathbf{R A} T E$, coiled, circiuate, or takiug a circular course. Compare Grrose.

G'Y $R O^{\prime} \mathbf{M A}$, an old term for the anuulus of ferus.

G'Y $\mathbf{Y} 0 \bar{S} E^{\prime}, \quad$ curved alternately backward and forward; nearly the same is Anfractuose. Sometimes used in the sense of Gyrate.

HĂB'ĬT, the general appearance or manuer of growth, as loose or compact, dwarf or otherwise, climbing, creeping, or upright. Also the character with regard to fruitfuluess, hardiness, etc.

HĂB'ĬTĂT, the kind of situation in which a plant is naturally found, as marsh, woods, mountains, etc. Compare HabitaTION.

HĂBITT $\bar{A}^{\prime} T I O N$, the entire locality or yeogruphical range within which a species is found. Com. pare Habitat and Station.

HĂD'RŌME, see XrLèr. Applied by Ptonie to the phloëmlike portion of tle fibrovascular bundle in vascular cryptogams.

HÂIR, any feeble outgrowll from the epidermis; trichome. Hairs may be of any shape, and may consist of one cell or more. They are usually derived from a single epidermal cell.

HÂIR-POINTED, terminating in a very fine weak point.

HÂAR'Y̌, covered with longer and 
coarser hairs than "pubescent."

HẠL'BẼRD-SHĀPED, see HASTATE.

HẠL'BẼRT-SHĀPED, see HAS'TATE.

HÄLF-A்N ĂT'RŌPOǓS, see AMPHITROPOUS.

HÄLF-BREED, applied in stockbreeding to a cross between a well-established breed and common (31" "scrul)" stock, but selitom used in botany. (L'sed by Burbidge in the seuse of (ross.)

HÄLF-ĚQ'UǏTANT, said of opposite leaves whose margins are folded forward and enclose the stem and one edge of the opposite leaf, leaving one margin of each leaf outside. Compare EqUiTANT.

HÄLF-INFF' $\bar{E}^{\prime}$ ǏOR, said of an ovary when the stamens are perigynous.

HÄLF STĚM-CLȦSP'ǏNG, sce SEMIAMPIAEICAUL.

HÄLF-SŨPE'RĨOR, see PERIGYNOT'S

HẢLǑPH'ǏLoŬS, salt.loving.

HĂL'ŌPHȲTE, a plaut containing a large quantity of common salt in its composition, and which thrives liest in salty places, as Silsola Küli.

HÄLVED, see DIMDIATE.

HĀ'MĀTE, looked,

HĀMŌSE', see HAџATE.

HĀ'MOǓS, see HAMATE.

HĂM'ŪLĀTE, diminutive of Hamate.

HĂM'ŪLŌSE, dimiuntive of $\mathrm{Ha}$ mose; bearing small hooks.

HĂM'ŪLǓS, a small hook.

HĂPLŌGŌNÍD'ǏUM, an algal gonidium in lichens resembling Protococcus. (Rare.)
HĂPLŌPẼRÍS'TŌMOǓS, lıving a peristome in mosses with but a single row of teeth.

HĂPLŌSTĚM'ŌNOǓS, having the stamens in one whorl.

HÄRD, said of fruits, chiefly pears, which require cooking to soft. eu them for eatiug.

HÄRD'Y̌, said of plants capable of passing the winter uninjured by cold. Harliness also iumplies the ability to withstand any injurious climatic influence, but its limited use referring to cold is most common.

HĂS'TĀTE, like the head of a liaberd-applied to leaves which liave a spreading lobe on each side of the base. Compare SAgiTTATE.

HĂS'TǏFÔRM, see HASTATE.

HĂS'TİLE, see HASTATE.

HĂTCH'ĔT-SHĀPED, see DoLABIRIFORM.

HAULM, the dead stems of any herbaceous plant.

HẠUSTŌ'RǏUM (pl. Hạustōrǐà), ihe special organ of certain parasites by means of which they obtain food from their liost.

HĔAD, any compact somewhat rounderl body upon a stem. The term is also applied to a cluster of nearly sessile flowers, as in the clovers and Compositx, also to other more or less compact inflorescences, as the spike, corrmb, and panicle. See Capitulum.

HEÄRT, the organic ceutre of anything, as the central portion of a tree-trink, or a growing point surrounded by leaves.

HEÄRT-SHĀPED, sce CORDATE.

HEÄRT-WOOD, see DURAMEX.

HĒEEECÄR'POŬS, having pubescent fruit. (Obs.) 
HĚB'ĒTĀTE, having aน obtuse point: bluuted.

HĚDẼRA' $\bar{A}^{\prime}$ EOŬS, pertaining to or resembling ivy.

HĚ D' ẼRAL, see HEDERACEOUS.

HĒLIÇ'IFÔRM, see HELICOID.

HĔL'İCOID, (1) coiled into the form of a lielix or suail shell; spiral; (2) in intloresceuce contrasted with Scorpioid, which see. See Helicond Crase and HELICOID DiCHO'TOMY.

HĚL'ǏCOID ÇȲME, one in which ench successive flower is situ. ated upon the sime side of a pseudaxis, which may or may not be coiled, as the priminy brauclies of the intlorescence of Hemerocullis fulve; bostry. choil cyme; bostryx; false riceme. Compare ScolzPIOID Crine.

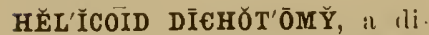
chotomy in which a branch on the same sile in each successive lifurcation continues to develop while the other does not; bostrychoid dichotomy. Compare Scorpioid Diciót OMY.

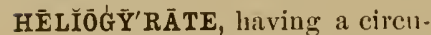
lar line curried obliquely around au object, as the anmu. lus on the spore-case of Trichomaues.

HĒLัOT'RŌPǏSM, having the power of movement uuder the influence of light.

HELL'MĔT, see GALEA.

HELL'MĚT-SHĀPED, see GALEA'TE.

HÉlō'BǏoŭs, see Palustrine.

HĔMĬ.ẢNĂT'RŌPOǓS, see AMPHITROPOUS.

HĚM'ǏCÄP, one of the ripened separable carpels of a dicarpellary fruit, as in Umbellifere: diachænium. S e e Mericare.
HĔM' ̌̌ÇYCLE, half of a coil or circle.

HĚMĬÇY̌C'LICC, having part of the Horal organs arranged in whorls and the remainder in a spiral. Compare Crobic and ACYCLIC.

HĚMİT'RŌPAL, see AMPHTROPOUs.

HĚMIT'RŌPOǓS, see AUPIITROPOUS.

HĚPTĂǴY̌NOǓS, haviug seven pistils or styles.

HĚPTĂM'ẼROUัS, laving seven parts.

HĔPTĂN'DRoƯs, having seven stamens.

HĚPTẢPĔT'ALOŬS, lıving seven petuls.

HẼRB, a plant of which the stem contains but little wood aud dies to the gromnl at the close of the seison. It may be an anmul, a biemnial, or a perennial.

HẼRB $\bar{A}^{\prime}$ ÇEOŬS, like an herb; succulent. Also green, as opposed to colored like an oriliuay corolla, as a petal with an herbaceous (green) tip.

HẼRBA' ÇEOǓS PĚRĚN'NǏAL, see Pereñial Herb.

HẼRB'AL, see HERBARIUM.

HẼRB $\bar{A}^{\prime} R$ ǏŬM (pl. Hèrbā'rǐumş or Herbā'rià), a classified collection of dried specimens of plants; herbal; hortus-siccus.

HERBEL'CENT, herbaceous or somewhat so.

HẼRBŌRǏZĀ'TION, see BOTANIZING.

HẼRCŎG'ȦMOǓS, said of an hermaphrorlite flower when some structural obstacle prevents self-fertilization, as in many orchids.

HẼRMĂPH'RŌDITTE, see PERFECT. 
HĚSPẼRĪ'IŬM, a fruit like the orange, being succulent within and corered with an indehiscent leathery rind.

HET $\bar{T} \bar{x}^{\prime} R I \overline{0}$, a collection of distinct inclehiscent carpels be. longing to a single tlower. They may be either dry upon a fleshy receptacle, as in the striawerry, or dry upon a dry receptacle, as in Ranunculus, or fleshy upon a dry receptacle, as in the rispberry. Usually but improperly spelled Eterio.

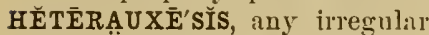
or unsymmetrical growtl, either normal or abnormal.

HÉTẼRŌCÄR'POǓs, bearing fruit of two or more kinds or forms, as in the geums Imphicarpea. Compare Hosucarpocs.

HĚTẼRŌÇĚPH'ȦLOǓs, bearing leads of more thin one kind. For example, having tlowerheads some of which contain only staminate flowers and some ouly pistillate.

HĚTẼRŌ€HRō'MOǓs, haviug different members unlike in color; also applied to a flower-head in Compositie whin the florets of the ceutre or disk differ in color from those of the circumference or ray.

HĚTẼRōCLI'NOUัS, laving male and female tlowers in separite heads or receptacles.

HĚT'ẼRŌÇY̌ST, one of the intercalated cells of special eharac ter in the filaments of Nostochineæ; limiting-cell. They are usually large, rounded, brownish, and glassy in appearance.

HĚTẼROัD'RōMOǓS, turning or coiling in opposite directions, as a tendril which coils first one way and then the other. or a plant on which the leaf-spiral of a brauch runs in the oppo- site direction from that of the main axis. Compare HosoDromous and ANTIDRomous.

HĔTẼRE'ÇIOǓS, parasitic on different plants at different stages of growth; metœcious; metoxenous; Leteroxenous.

HĚTẼREÇǏS̆MAL, see HETERECIOUS.

HĚT'ẼRĒÇY̌ST, sec HETERoCYST.

HĚTẼRŎG'A்MOǓs, said of the heads of Howers in Compositæ when the florets are not all alike in sex.

HĚTẼRŌGE'NẼOUS, not of uniform substance or character.

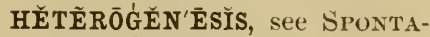
NEOC'S GENERATHON.

HĚTẼRŎG'0̄NOǓS, having two or more kinds of flowers differing in the relative lengths of the stamens and styles; heterostyled. See Drmorphous and 'I'RIMORPHOUs.

HĚTẼRŏM'ÁLOǓS, spreading in all directions. Compare HoMOMA LOUS.

HĔTẼRŎM'ẼROǓs, having a different number of parts in the different whorls of a flower. Compare Isomerous. Applied also to a lichen thallus when a layer of the algal cells divides it into an outer cortical and an inner medullary portion. Compare Homoromerous.

HĚTẼRŌMÔR'PHOǓs, of two or more forms, as the flowers of Buchloë dactyloides.

HĚTẼRŌPHY̌L'LoǓs, having two or more distinct sorts of foliage. leaves on the same plant, as in junipers; also applied to speeies whose leaves differ widely from those of related species. The term is not usually applied to plants in which the leaves merely assume difterent forms at 
successive elevatious on the stem.

HĚTẼRŌRHİ'ZAL, having roots which seem to proceed from no tixed point, as thuse of acrogens; said also of spores which germiuate indifferently from any portion of the surfice. Little used.

HĚTẼRŎS'PŌROǓS, beariug aseXually produced spores of more than one kind. as in the Urediuere; having macrospores and microspores, as in Selaginella. Compare Hoso. sPolious and Isosporous

HĚT'ẼRōSTȲLED, see HETERUGONOUS.

HĔT'ẼRŌTăXY̌, the deviation of organs from their normal position.

HĚTẼRŏT'RŌPAL, see AMPHI'TliOPOUS.

HĔTẼRŎT'RŌPOǓS, see AMPHITropous. Also applied to any part which is turned in an unusual direction.

HĚTÊRŎX'ẼNOǓS, see HETEREClOUS.

HĔX., a prefix derived from the Greek, meaning six. See SEx-.

HĖXĂG'Y̌ NOǓS, having six pistils or styles.

HĚXĂM'ẼRoǓs, having the parts in sixes. Applied mainly to the pirts of a flower, and meaning six organs in each whorl. Also written 6-merous.

HĚXĂN'DROǓS, laaviug six stamens; hexastemouous.

HĚXȦPĚT'ALOǓS, having six petals.

HĚXẢPHY̌L'LOǓS, lnaving six leaves or leatlets.

HĚXȦSTĚM'ŌNOǓS, see HEXANDlROUS.

HĪBẼR'NÄCLE, see HIBERNACULUM.
HĪBẼRNĂC'ŪLŬM, ¿ protection for a growing part through the winter, as a bud or bulb.

HĪBẼR'NAL, pertaining to winter; blooming or vegetuting in wiuter; hiemal; hyemal.

HİBẼ RN $\bar{A}^{\prime} T I O N$, passing the winter in a dormant condition.

HIDDEN-VEINED, laving the veius of a leaf buried in the tissue so as not to be easily visible.

HIDE-BOUND, see BARli-BOUND.

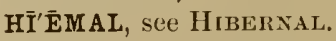

HI'LAR, pertaining to the hilum. HĪLE, see HiLuI.

HII'LŬM (pl. Hïllà, or preferably Hī'lüms), the scar, or point of attachment of a seed. The term is also applied to the nueleus of a starch-grain.

HIP, the fruil of the rose; a cynatrhorlium.

HǏPPǑCRĔP'ǏFÔRM， horseshoeshaped.

HĨRSUTTE, clothed with rather numerous long conrse hairs. harsher than pubescent and less harsh than hispid.

HĨ R'TŬS, indefinite in meaning, but nearly the sime as Hirsute, wuich see.

HĨRTĔL'LOŬS, slightly hirsute; stiffly pubescent.

HǏs'PID, clother] with erect stiff hairs, as Borage.

HǏSPĨD'ŪLOǓs, minutely hispid.

HǏSTǏŏL'ōGY̆, see HistologY.

HĬSTŌDİ̆L'Y̌sǏs, the separation of the cells of a tissue from each other.

HǏSTŌGĒEĚT'ǏC, tissue-forming; pertaining to histogeny.

HǏstōGĚN'Ǐc, see HistogeNETIC.

HǏsTǑG'ĚNY̆, the origin or formation of tissue. 
HǏSTŏL'0̄'Ğ, the science of the structure of tissues. Compare MORPHOLOGY.

HōARY, grayish white; canescent.

HŌLD'-FAST, any root or root-like organ whose chief function is to retain the plant in place, as the aerial roots of ivy, or the suckers or rlizoids of mauy sea-weeds; crimpon.

HŏLẼRA'ÇEOǓS, see OLERACEOUS.

HŏLōCÄR'POỨS, having the pericarp entire. (Rare.)

HǑLŌSĂP' RŌPHȲTE, a complete saprophyte: one which lives entirely on dead organic matter.

HŏLŌSĒRIĆ'EOŬS, covered with very short silky hairs hardly visible to the eye. Compare VELUTiNous.

HŌMŌBLĂS'TĬC, said of the embryo when in its usual position with the radicle directed toward the micropyle and the cotyledons in the opposite direction. Compare EnaNTIOBLASTIC.

HŌMŌCÄ R'POǓs, bearing fruit all of one kind. Compare HETEROCARPOL'S.

HŌMŌÇĚN'TRǏC, see CONCENTRIC.

HŌMŌ€HRŌ'MOǓS, of uniform color.

HŌMŎD'RŌMAL, see HowODRoMOUS.

HŌMǑD'RŌMOǓs, turning continnously in the same direction. Compare Heterodromous.

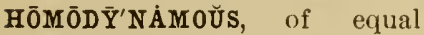
strength, size, or vigor.

HŌMŎG'ÄMOǓS, having all the florets of a head in Composita alike in sex. Compare HETE- rogayous. Also used for Synacmic, which see.

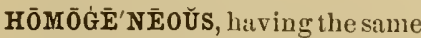
nature or structure throughout.

HŌMǑG'0̄NOǓs, having the stamens and pistils alike in character in all flowers of the species; homostyled. Compare HeTERogonous.

HŌMOIŎM'ẼROǓs, applied to a lichen thallus in which the gonidia and hyplix are mingled together and not distinctly stratified. Compare HETEIROMEROUS,

HŌMŎL'ŌGOǓS, of the same morphological natme, as leaves, bracts, sepals, petals, stamens, and pistils are all homologous, or forms of the same fundamental organ.

HǑM'ŌLǑGUE, a part homologoıs with another, as a stamen with a leaf; homotype. Compare Analogue. A nectary, for example, is in some cases the h omologue of a stamen and in others of a petal, but it is always the analogue of any other nectiry.

HŌMŎL'ŌĞY̆, correspondence in structure or morphological nature. Compare Analogr. See Homologous and Homo. LOGUE.

HōMŏM'ÁLOỨs, applied to leaves or other organs which originate on the different sides of a stem, but are all tmued toward one sidle. Compare SECUND.

HŌMŌMÔR'PHOǓS, of the same shape or character, as when the disk-flowers as well as the ray-flowers of a head in Com. positie are ligulate.

HŌMŌPĽT'ALOŬS (obs.), see REGULAK.

HōMǑS'PōROǓs, lhaving asexually produced spores of only 
one kind; isosporous. Compare HeTEROSPOROUS.

HŌ'MŌSTỸLED, see HoMOGoNUUS.

HōMǑT'RōPAL, see HoมOTROPous.

HŌMǑT'RŌPOǓs, said of an embryo in a curved seed when it is curved in the same manner as the seed.

HŎM'ŌTȲPE, see HoMOLOGUE.

HÓN'EY, see Nectar.

HON'EY-CŌMBED, see ALVEOLATE.

HON'EY-DEW, a sweet substance found on the leaves of plants, usually a secretion from plant. lice.

HON'EY-GUIDDE, see NECTARGUIDE.

HON'EY-PŌRE, the supposed pore in Howers which secretes honey. (Obs.)

HON'EY-SPǑT, sec NECTARGUIDE.

HOัOD, see Cucullus.

HOัOD'ED, see CUCULLATE.

HOOOD'-SHĀPED, see CUCULLATE. HOOP, the connecting band between the valves in Diatomacer.

HŎRĬZŎN'TAL SY̌STĔM, the cellular as distiuguished from the fibroviscular system. Little used.

HôR'MŌGŎN, sec HoRMOGONIUM. HôRMC̄GōNI'ŬM (pl. Hôrmōgōo$\left.n^{-1} \hat{a}\right)$, a reproductive body in certiin algie, as the Oscillatorier, cousisting of a sliort chain of cells, oue of the natural fragments of a filament.

HôRN, any hor'u-shaped appendage, as the spur of a flower.

HôRN'LĚT, a little horn.

HôRNY, of the texture of a horn, as the pericarp of witch-hazel, Hamamelis Virginicu.

HǑRŌLǑG'ǏCAL, said of flowers which open aud close at definite hours of the rlay.

HÔRTĚN'SǏs, pertaining to a garden.

HôR'TUัS-SÍC'CǓS, see HerBARIUU.

HŌȘE-IN-HŌȘE, when the calyx in a gamopetalous flower takes the form of the corolla, or when the corolla itself in such a Hower is in two parts or whorls.

HōōT, a plant which supports a parasite.

HŌST'-PLĂNT, see HosT.

HU' MİF'SE, spreadiug upou the groimcl.

HUU'MILIS, low, or less in stature than related species, but not necessarily dwarf; pumilus.

HŪ'MǓS PLANT, see SAPROPIITTE.

HǓsK, any large, dry, thin envelope covering the fruit or inflorescence, as one of the bracts surrounding a ear of corn.

HȲALĚS'ÇENT, somewbat hyaline.

H $\bar{Y}^{\prime} \dot{A} L I N E$, clear and colorless like glass or water; translucent or trausparent.

HY̌' ÁLŌPLĂSM, the clear portion of the protoplasm free from granules. Often restricted to such a layer next to the cellwall, then called by some Ectoplasm.

HȲ $\mathbf{B E ̃} \mathbf{R}^{\prime}$ NÁCLE, see HiBERNACULUM.

HY Y' BẼRNĀTǏNG, sce HrBERNATING.

HY' $\bar{Y}^{\prime} B R I D$, the offspring of two species of the same genus. Compare Cross. The term 
Hybrid is often erroneously used to designate the result of cross-fertilization between any ditrerent species or varieties. As true hybrids areof ten sterile, the term " mule" has been ap)plied to them. Burbiclge proposes to retain the term "mule" for sterile hybrids only. See Genus-Hínid.

HȲBRĬDIZA'TION, the fertilization of a tlower by pollen from a. plant of another species. Often erroweously used for cross-fertilization in general.

H'̃'DROID, see TRACHEID.

HȲDRǑPH'ǏLOUS, having the pollew conveyer to the stigma by means of water.

H $\bar{Y}^{\prime}$ DRŌPHÝ'TE, an aquatic plant of any kind.

HȲDRǑT'RŌPIȘM, power in a growing organ of turning in a definite manuer or direction through the influence of moisture, i.e. of taking a defuite position with respect to the source of moisture. See Positive and Negative HyDRotropisa. Compare HYGROSCOPIC.

HY $\bar{Y} \bar{E}^{\prime} M A L$, see HIBERNAL。

HȲGRŌMĚT'R ǏC, moviug in a definite manner as a result of a change in the degree of moisture: bygroscopic.

HȲGRǑPH'ÁNOǓS, haviug a watery appearance.

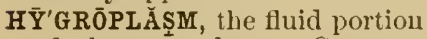
of the protoplasm. Compare STEREOPLASM.

HȲGRŌSCŌP ǏC, (1) alosorbing moisture with avidity; (2) showing an increase or diminution of moisture by motion; Lygrometric. Compare HYDRoTROPISM.

HȲGRŌSCǑP'ǏC ČLLLS, certain ('ells in the leaves of grasses which have the power of altering their form under the intluence of moisture and causing the leaves to "curl" in dry weather. From their bladderlike appearance they are also called Bulliform Cells.

HȲME'NǏŬM (pl. Hȳmé'nīa), a spore-bearing surface in fungi, especially in mushrooms and their allies.

HȲMĚN'0̄PHŌRE, the portion of a sporophore immediately beneath a hymenium; hymenophorum.

HȲMẼNŏPH'ŌRǓM, see HYMENOPHORE.

HȲPĂN'THĬŬM, an expanded, usually Heshy, receptacle, more or less enclosing the flowers, as in the tig, rose, Dorstenia aud Ambora; hypauthodium. See Hip and Srconus. Compare Clinan. THIUII and RECEPTACULAR TLBE.

HȲPĂNTHŌ DĬŬM, see IYPANTHICXI.

HȲPẼRBŌ'REAN, glowing in the extreme nortl.

HȲPẼR'TRŌPHY̌, excessive development. Compare ATroPHY.

H $\overline{\mathbf{Y}}^{\prime} \mathbf{P H} \dot{A}$ (pl. Hy'phæ̈), a filament of mycelium.

HȲPHĂS'MA, an oìd term for mycelium, still oceusionally used when particularly delicate aud web-like.

HY̌P'NŌSPẼRM, an asexually produced resting-spore in algre; hypuospore.

HY̌PNŌSPŌRĂN'GIUUM, a sporangium containing resting-spores.

HY̌P'NŌSPŌRE, any restingspore, especially oue produced asexually. Compare Hrisosperm. See Resting-sporie. 
HYPO-, in Greek derivatives, under.

HȲPŌCÄRPŌGE'AN, producing fruit beneath the surface of the ground, as the peanut.

HY̌P'0̄€HǏL, see HYPochILILI.

HȲPōeHǏL'ǏŬM, the lower or basal part of the divided labellum in certain orchids: hypochil. Compare EPIchilius.

HȲ'PōcŏTY̌L, the caulicle. Compale EpIco'Tra.

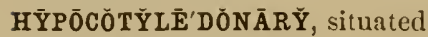
below the cotyledons.

HY̌PōCRẢTĚR'ǏFôRM, having a long tube with an abruptly spreading border, as in phlox; salver-forn.

HY̌P'ŌDĚRM, sEe HYPODERMA.

HY̌PŌDẼR'M $\dot{A}$, cells or layer's of cells next beneatlo the epidermal system which are developed in a special manner, usually as collenchyma or other strengthening tissue.

HY̌PŌDẼR MAL, situated beneath the epiderusis; hypodermous.

HY̌PŌDÊR'MOǓS, see HYPODERIIAL.

HY̌PÖĞ $\bar{E}^{\prime} A N$, see HYPOGEAX.

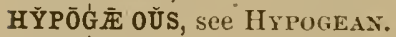
HY̌PōǴ'̄'AL, see HYPoGEAx.

HY̌PŌGE'AN, subterranean: applied to parts which grow beneatl the surface of the ground, and to plants which ripen their fruit beneath the surface; lypogrean; hypogatous: hypogeal; hypogeous.

HȲPǑG'ENOÚS, growing upon the lower surface of anything.

HY̌PŌGE'OǓS, see HYPOGEAX.

HȲPOG'ÝNOǓS, growing beneath the pistil, and free.

HȲPŌNĂS'TĬC, denoting curvature from growth on the lower side of an organ, causing it to bend upward. Compare EPIX.A.'TIC.

H $\bar{Y}^{\prime}$ PONA ÁSTY̆, having more rapid growth npon the lower than upon the upper surface. Compare Episastry.

HȲPŌPHLCE'ŌDAL, beneath the bark.

HȲPǑPH'Y̌LLOǓS, situated upon the lower side of a leaf.

HȲPŌPHY̌L'LǓM, an abortive or scale-like leaf subtending anything. (Rare.)

HȲPǑPH'Y̌s̆́s, an appropriate but seldom used term for the Apophysis in mosses.

HȲPŌTHĂL'LŬS, a lower or interior stratum in a thallus.

HȲPŌTHE ĖİUM, a portion of the thallus beneath or around the apothecium in lichens.

HY̌P'SŌPHY̌LL, see BRACT.

HY̌STẼRĂN'THOǓS, stid of plants which lave the tlowers expand after the leaves have appeared. The leaves therefore in a hysteranthous plant ire proteranthous.

HY̌ST ẼRŌĞĽE'IC, formed late; applied to intercellular spaces formed in older tissues. Compare Protogexic.

İcōs-, in Greek compounds, twenty.

$\overline{\mathrm{I} C O \overline{S A}}$ N'DROŬS, having twenty or more perigynous stamens. Compare Polyandrols.

İDĚNTǏFǏCÁ'TION, see DETERMINATION.

ĬD'ĪōBLĂST, a single cell in a tissue which ditfers greatly from its neighbors in form, size, nature of cell-wall, or cell-contents.

ĬD ǏŌPLĂSM, a term applied by Nigheli to the active organizing part of the protoplasm. 
ÍG'NẼ $\mathbf{U} S$, fiery-red, a lively scarlet.

ĬMBẼR'BIS, without a beard or other hairs. See Glabrots.

İMBİI'TION, the addition of moisture to organized bodies iu a manner which canses them to swell up. Compare ABSORPTION.

ĬM'BRĬCĀTE, overlapping like tiles or shingles on a roof, as the scales of buds. In restivation at least one piece is wholly exterual aud one wholly intermal.

ĬM'BRĪCĀTĚD, see IUBRICATE.

IM'BRICĀTIVVE, see IMBRICATE.

IMMÄR'GĬNÄTE, without a distinct rim or border.

ĬMMĖRSED', (1) growing wholly under water; demerserl; submersed. (2) When one part or organ is completely embedded in another; inuate. Compare Eversed.

IMMMǑTĚLLES', a telm applied to various plants, the Howerheads of which retain their origiual shape and an attractive appearance when dried, as Graphalium and some other Conposite; everlasting flower's.

İMPĂRǏPÍN'NĀTE, pinuate witl a terminal leaflet, thus usually making an odd number; oddly pinuate.

IMMPẼR'FĔCT, said of a flower which lacks either stameus or pistils.

İMPẼR'FŌRĀTE, closed; without an opening.

ĬMPRĔGNÁ'TION, see FERTILIZATION.

IN-AND-IN, breediug for successive generations from closely related individuals. Growing a "stock" or "strain" of corn on the same farm for many years would be called in-andiu breeding.

INĀNNE', empty.

İNĂN'THẼRĀTE, beariug no anther: said of certain sterile filaments or abortive stameus.

INÄRCH'ING, the natural union of stems or roots which grow in contact; natural grafting. Also applied in horticulture to a form of grafting in which both stock and scion remain at first attached to their own roots.

ǏNÄRTĬC'ŪLĀTE, not jointed; continllous.

ǏNCÁNĚS'ÇENT, sCe CANESCENT. Strictly, somewhat or slightly canescent.

ÍNCĀ'NOǓS, see CANESCEN'T.

INÇİSED', irregularly and deeply cut into rather large lobes.

ÍNCLINED', gradually bent out of a perpendicular at less than al right angle, as the brauches of most decidious trces.

ǏNCLŪD' $\breve{E} D$, contained in a cavity and not projecting beyond it; euclosed. Compare Exsertated.

INCÓMPLETTE', destitute of some part which is usually present; said especially of flowers which lack one or more of the four sets of primary organs, sepals, stamens, and jistils.

ÍNCŎNSPĬC'ŨOǓS, small in size; not readily observed.

ǏNCRĂS'SĀTE, thickened; especially, gradually thickened or enlarged upward from the base.

INCRĚS'ÇENT, growing.

INNCŪBA'TION, the period from the time of infection or the sowing of the spores until a bacterium or fungus becomes externally or visibly manifest. Applied mainly to pathogevic bacteria affectiug animals to indicate the period from the 
time the organism euters the body until the disease appears.

IN ${ }^{\prime}$ CÜBOǓs, having the tip of one leaf overlap the base of the one above it, as in the Jungermanniacere. Compare Succubous.

ÍNCUัM'BENT, leaning or lying upon; applied to cotyledons when the radicle is folded against the back of one of them (the radicle in such case being dorsal). Compare AcCUIBENT. An anther is incumbent when lying on the inside of the filament to which it is attaclied. Compare VERSATILE.

ÍNCŨR' $R^{\prime} \overline{T E}$, see INCURVED.

İNCŨRVED', bent or curved inward; incurvate.

ÍNDĒÇİD'ŪOǓs, either evergreen or persistent.

ǏNDĚF' ǏN ǏTE, either uncertain or not uniform in number, or too many to be readily counted; uumerous; over twenty when applied to stamens. Also applied to objects which have no well-defined boundary or ontline.

ǏNDĚF'ǏNITE GROWTH, see InDETERMINATE.

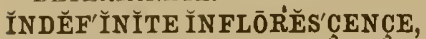
SEe INDETERMINATE.

ǏNDËHIS'CENT, not opening in a definite manner at maturity to discharge the contents. The fruits of the pea and lily are dehiscent, those of the tomato and apple indehiscent.

ǏNDĒTẼR'MǏNĀTE, a mode of centripetal intlorescence in which the flowers all arise from axillary buds. Applied also to all stems which do not produce a well-developed terminal bud at the close of the season, as the grape. Compare Determinate.
ǏNDǏF'FẼRENT, und i ff ere ntiated; not specialized; as in. different cells or tissues.

ǏNDǏG'ẼNOUัS, strictly native; aboriginal. Compare NaruTRALIZED.

INDǏVID'ŪAL FERTILIZA'TION, a term applied by L. H. Bailey to eross-fertilization between different flowers upon the same plant.

ǏNDŪMĚN'TUUM, any hairy covering upon plauts.

ÍNDÜP'LICCÁTE, having the margins folded inward. Compare InVOLUTE.

ǏNDŪRĂS'ÇENT, becoming hard. ÍN'DÜRĀTED, hardened.

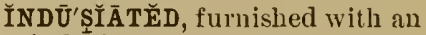
indusium.

ǏNDU'SǏǓM, an outgrowth of the epidermis covering the sorus in many kinds of ferns; shield. Also applied to a ling of " collecting lairs" below the stigma, as in Lobeliacex.

IัNDU'SĬǓM, FALSE, see FALSE INDUSTUM.

ǏND $\bar{U}^{\prime} V \check{I}$ E, any parts of the flow. er which persist and cover the fruit, at maturity; also dead and withered leaves which remain persistent on the stem. Compare RELIQUIA.

ǏNEQQUILLĂT'ẼRAL, u n e qua 1 sided.

ǏNẼR'MOǓS, unarmed; destitute of spines, prickles, etc.

ǏNFÄRCT'ÁTE, see FARCTATE.

İNFĚC'TIOUS. In ordinary use this term has the same sense as Contagious, being applied to all diseases which are communicable from one plint or animal to another by direct contact or otherwise. In a broad sense infectious includes Contagions, as defined under that 
term, and applies also to diseases originating from germs which are able to vegetate for a tinte at least outside of the affected plant or animal. In a strict seuse Iufectious applies only to cliseases produced by organisms which have their natural home outside of the infected body.

INFE'RÍOR, lower, as an ovary to which the other floral organs are adnate so that they arise from its summit. If the other organs are free from the ovary the $y$ are inferior and the ovary superior, thougl the term is seldom applied to them. The inferior sicle of a leaf or Hower is the lower or anterior side which faces away from the supporting axis or stem.

INFL $\bar{A}^{\prime} T \check{E} D$, puffed up; bladdery. INFLĚCT'ĚD, sec INFLEXED.

INFLEXXE', abrupt]y bent inward or downward: inflected.

ǏNFLŌRĔS'ÇENCE, (1) the arrangement of the Howers or Hower-clusters on a plant; anthotaxy. Compare PhrlloTAxY. (2) The portion of the plant which bears the flowers and fruit, i.e., a flower-cluster of any kind.

ǏNFRA- $\breve{A} X^{\prime}$ ǏLLĀRY̌, situated below the axil.

ǏNFRĂC'TĚD, see INFLEXED.

INFRŬCTĚS'CENCE, an inflorescence in fruit; the fruiting portion of a plant, together with its fruit. Little used, and applied mainly to collective fruits.

ǏNFUัNDǏB'ŪLAR, see INFUNDIBULIFORM.

ǏNFUัNDǏB'ŪLIFF̂RM, funnelshaped; having a tube which gradually enlarges upward and bears a moderately spreading border, as Datura. Compare HYPOCRATERIFORM.

INI'TIAL CELLS, the first formed cells of a tissue.

INJEC'TION, filling of intercellular spaces by water, an occurrence which rarely happens.

ǏNNĀTE', (1) said of anthers attached by their base to the apex of the filament; such antluers are sometimes called Vertical; (2) said of an organ or object which grows within the substratum, as "mycelium or perithecia innate," i.e., growing within the tissue of the host.

ÍN'NẼR LĂM'ÍNÁ, the layer of a lignified cell-wall adjoining the inside of the cell. Compare MiddLE LAMINA.

INNŌVA'TION, a new or alditional growth or shoot, as the supplementary extensions of the stem in mosses. Applied also to an entire group of offgrowths of the same morphological value if some of the forms are true innovations in their manuer of growth; thus Dr. William Trelease applies this term in Epilobium to forms which vary in different species from sessile luds to dense rosettes, running leafy shoots, scaly rluizomes, and filiform bulbiferous stolons.

ǏNǑS'CŪLATING, opening into each other; anastomosing.

INSẼRT'ĚD, attached to or grow. ing out of, as stamens inserted on the corolla.

INNSẼR'TION, the place or mode of attachment.

ǏNSPǏS'SĀTĚD, thickened by drying.

ǏNSTǏP'UัLĀTE, see ExsTIPULATE. 
ǏNTĒGRǏFō'LǏoǓs, having entire leaves.

INTĚG'ŪMENT, any covering layer or membrane.

IN'TẼR-, in composition, between. Compare INTRA-.

ǏNTẼRĂX'ILLĀRY̆, betweeu the axils.

ǏNTĚR'CA்LATTĔD, inserted between or in the midst of.

ǏNTẼ RCÄR'PĚLLĀRY̌, between the carpels.

ǏNTERRÇĚL'LŪLAR PASS'AGE, a continuous opening between the cells.

ǏNTẼRÇĚL'LŨLAR SPACE, any cavity within the plant. Usually applied to smaller openings than intercellular passages.

ǏNTẼRÇĚL'LŨLAR SUB'STANCE, material extruded from the cells within the plant.

ǏNTẼRÇĚL'LŪLAR SY̌S'TĚM, the intercellular spaces and material of a plant taken together.

INTẼ RCǒs'TAL, situated between the ribs of a leaf.

ǏNTẼRFǍSCİC'ŨLAR, between the bundles: said of a layer of cambium which extends from one fibrovascular bundle to another.

INTEERFI'LAR, between the filaments, as the resting-spore in the conjugation-tube of Mesocarpus, or the fluid portion of the protoplasm in the hypothetical fibrillar network. Compare INTRAFILAR.

INTẼRFŌL Ĭ $\bar{A}^{\prime}$ ÇEOǓS, attached to the stem between the bases or petioles of opposite leaves; interpetiolar. Compare INTRAFOLIACEOUS.

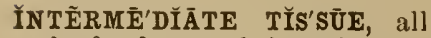
the fundamental tissue in exogens, except that which is immediately associated with the epidermis and the fibrovascular bundles. It includes the pith, medullary rays, and most of the cortex. The term is of little use.

ǏN TẼRME' DİĀTE ZŌNE, the zone in eudogeus between the pith and epidermis containing the fibrovascular bundles.

INTẼ R'NAL GLAND, a secreting cell, or usually a cluster of secreting cells, within the plant, as those containing es. sential oil which form the translucent dots in the leaves of the orauge.

ǏN'TẼRNŌDE, the portion of a stem between two nodes.

ǏNTẼRPEัT'ĪŌLAR, see INTERFOLIACEOUS.

ǏNTẼRRUัPT'ËD, said of any surface or series the continuity of which is broken, as a pinuate leaf in which leaflets much larger or smaller than usual are interposed among the other's, or a slender stem or root which is coutracted at intervals.

ǏNTẼRRŬP'TĚDLY̌ - PǏN'NĀTE, pinnate with small (or sometimes large) leatlets interposed between those of the usual size.

ÍNTẼRSTÍ'TIAL, applied to that method or theory of growth which consists in the interposition of new particles between the older ones instead of additions to the surface.

INTĚX'ǏNE, see INTEXTINE.

INNTEX'TǏNE, a ter'm applied by Fritzsche to the inner part of the extiue when, as in CEnothera, it separates as a distinct membraue. Compare Exintine.

ÍN'TÍNE, the inuer coat of a pollen-graiu. 
ÍNTÔR'TION, turning to one side from the vertical or auy straight line. (Rare.)

ÍN'TRÁ-, in composition, within. Compare INTER-

ǏNTRÄCÄR'PĚLLĀRY̌, produced inside a carpel.

ÍNTRẢÇĚL'LŪLAR, withiu a cell.

İNTRÁFĂSÇIC' ÚLAR, within the bundle, as an intrafuscicular lacıua in Equisetum.

INTRÁF'́ $L A R$, within the filament. Compare IN'TERFILAR.

ÍNTRÁFŌL $\breve{I A}$ 'ÇEOǓS, within a leaf; between the leaf and stem, as the stipules of Polygonum; intrapetiolar. Compare INTERFOLIACEOUS.

INTTȦLĂM'ĔLLAR, within special layers or lamella, as the trama of Hymenomycetes.

INTRẢMÄR'GINAL, s i t u a t e d within but near the margiu.

ÍNTRÁMĂT'RICCAL, in a matrix ol nidus.

ǏNTRẢPĚT'ĪōLAR, (1) inside or beneath the petiole, as the burls of sumach aul sycamore (sub. petiolar); ( 2 ) between the petiole and the stem, as the stipules of sycamore and most buds; intrafoliatceous.

İNTRÅV̆́G'ǏNAL, within the sheath: applied to branches in grasses which in their growth do not breuk through the base of the sheath of the subtending leaf, but push up)ward between the sheath and the stem. Compare ExrraVAGINAL.

INTRŌDŪÇED', applied to plauts brought from another country. and growing spontaneously unless otherwise noted. Compare NATUlaLIZED.

INTRŌFLĚXED', bent strongly inward. Between Iucurved and Infracted.
ÍNTRôRSE', faciug or turuing inwird. Applied to anthers which open on the side next the pistil.

INTRUD' pushed inward or indented; intruse.

INNTUัSSŬSÇĔP'TION, the inter. calation or formation of other particles among those already present.

ǏN'ŪLIN, a material isomeric with (resembling) starch which replaces that substance in many Compositæ.

ǏNVĂG'ǏNĀTĚD, iuclosed in a slieath.

ÎNVẼRSE', see INVERTED.

ǏN VĖRT'ĽD, haviug a position or mole of attachment the reverse of that which is usual; inverse. A seed or ovule is inverted when attached to the top of the ovaly. It is tlien, however, more properly called "suspended." Com par e ERECT and Ascendixg.

ǏNVẼRT'ĚD SŪPẼRPǑS̆'TION, the situation of accessory buds below the principal bnd or one first formed. Compare Direct Superposition.

ǏN VŏL'ŪÇ̌̌L, a partial or secondary involncre, as ove subteuding a partial umbel.

ǏNVŌLŪÇĚL'LǓM, see INVOLUCEL.

ǏNVŌLU'CRAL, pertaiuing to au involucre.

ǏNVŌLŪ'CRĀTE, having an involucre; involucred.

INN'VŌLŪCRE, a set of bracts immediately subtending a flower or intlorescence; involucrum.

İN'VŌLŪCRED, see INYOLUCRATE.

ǏNVŌIUU⿱一兀) CRLT, see INVOLUCEL. INNVŌLU'CRŬM, see INVOLUCRE. 
ǏN'VōLŪTE, rolled inward from both sides. Compare CoNVOLUTE.

ǏNVŌLU'TION-FôRM, a swollen bladder-like form in Schizomycetes, supposed to be a diseased condition of the form with which it is found associated. (De Bary.)

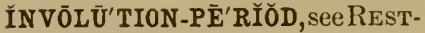
ING-PERIOD.

ÍNVŌLÜ'TION-STĀGE, see RESTING-STAGE.

ÍRRĔG'ŪLAR, denoting flowers in which one or more of the organs of a set are different in size or form from the others. Irregularity occurs most frequently in the petals. The pea is an example of an irregular flower, the tulip of a reguliar. Compare SrmietRICAL.

ǏRRĔG'ŪLAR PẼLŌ'RǏÁ, a teratological condition in which an irregular flower becomes regular by the formation of the irregular parts in increased number. Compare Regular Peloria.

ǏRRĬTẢBÍL'ǏTÝ, having the power of movement in a definite manner under the influence of external stimuli, as in the coiling of teudrils, twining of stems, or "sleep" of leaves; sensitiveness. Compare Excitability and ConTRACTILITY.

İSẢDĚL'PHOǓS, having an equal number of stamens in eacl adelphia.

İSŌBILLĂT'ẼRAL, having two sides alike in form and structure, as the leaves in the iris.

İš̉'RIIOǓS, applied to the embryo of dicotyledons because both are equally developed; isodynamous. Little used.
İsōeHRō'Ǔs, uniform in color throughout; unicolor. Compare CONCOLOR.

İSŌDY'NẢMOǓS, equally developed.

İsŏG'ÁMÝ, the conjugation of gametes of similur form. Compare Ö̈gamy.

İsŏG Y̌NOǓS, having the pistils of a flower all alike. Compare HeTERUG YNous.

İS̄̄MĚR'ǏC, see IsOMERoUs.

ISǑM'ẼRoǓs, having the same number of organs in each floral whorl; isomeric. There may be more than one whorl of any of the kinds of organs. Compare Heteronerous.

IsǒPH'0̄ROǓs, transformable into sometling else, as "Actinia is an isophorous form of Dendrobium."

I'SŌSPŌRE, said of a spore when all are alike, as in ferns. (Rare.) Compare Macrospore and Microspore.

İǒS'PŌRoŬS, not having macrospores and microspores: homosporous. Compare Heterosporous.

İsōSTĚM'ōNoǔs, having the stamens equal in number to the petals. More properly, having the stamens and petals ench in one whorl and of equal number. Compare Anisostenonous, Meiostemonous, Diplostenonous, and OBDIPLOSTEMONous.

İsǒs'TōMoǔs, having calyx and corolla of equal size. (Ralre.)

ISTH'MǓS, the constricted portion between the two lialf-cells in most desmids.

JOINT, a vode; the septum between two cells in a filament; articulation. 
JŪ'BÁ, a loose panicle. (Obs.)

JU' 'GŬM (pl. Jü'gà), (1) one of the ridges on an umbelliferous fruit; (2) a pair of leatlets in a pinuate leaf.

JŪL $\bar{A}^{\prime}$ ÇEOǓS, see AyENTACEOUS. JU'́LIFôRM, resembling an ament or catkin.

JŪ'LŬS, see AMENT.

JŪVĒNĚS'ÇENCE, see REJUVE. NESCENCE.

KĂRY̌̄oKĪN $\overline{\mathbf{E}}^{\prime}$ SǏs (also spelled Caryocinesis), Schleich er's term, which has been generally aclopted, for the transformations of the vucleus during cell-division; indirect division of Fleming.

KĂRY̌ŏL'Y̌šs, the dissolution of the nucleus or some part of it.

KĂRY̌ŌMITTŌ'SǏs, see undel MITOOSIS.

KĂR'Y̌ōPLĂȘM, see NUCLEOPLASM.

KĂRY̌ ŌSō'MẢ (pl. Kăry̆ōsòm'àtà), a consolidated mass of microsomata in a nucleus.

KĂTÁBǑL'ǏC, a term applied by Gedales to disruptive, destructive, or descending metabolism, accompanying the waste of tissues, resulting in the formation of chemical products of simpler composition; catabolic. Compare ANa Bolic.

KȦTHǑD'ǏC, see CATHodic.

KEEL, a ridge somewliat resembling the keel of a boat; particularly the two inferior petals of a papilionaceous Hower which are more or less united into a keel-shaped body; ca. rina.

KEELED, having a keel or longitudinal ridge; cariuated.

KĚRȦMǏD'ǏU, see CERAMIDIUM.
KEY, see SAMARA.

KEY-FRUIT, see SAMARA.

KID'NĚY-FÔRM, see RENIFORM.

KID'NEY-SHAPED, see RENIFORM.

KNEE, a kind of knot which projects upward into the air from the roots of the bald cypress (Taxodium distichum) and some other trees. Produced mainly in wet soil, aud formerly supposed to serve for aeration, but now believed to be an organ of strength. See Pneumatode. 'The term kinee is also applied to any abruptly bent or knee-shaped organ.

KNEE-JOINTED, S'e GENICULATE.

KNEEPAN-SHAPED, see PATELLIFORM.

KNOT, a node or swollen joint; a protuberance on the surface of a tree, as where a branch has been removed and the cut or broken surface is more or less overgrown; a place in the wood where the tissues are displaced by an injury or by the passage of a branch.

KNOTTED, cylindrical, and swollen at intervals, somewhat like a knotted cord.

IẢBĔL'LŬM, the large lower petal of an orchid; lip.

I $\overline{\mathbf{A}}^{\prime} \mathbf{B} \check{\bar{A}} \mathrm{~T}$ E, gamopetalous, with two divisions, anterior and posterior; two-lipped; bilabiate. The two lips of a labiate flower are usually unequal and the Hower irregular, as in suap-dragon.

L $\overline{\mathbf{A}}^{\prime} \mathbf{B} \check{\text { I O}} \mathbf{S E}$, having the petals of a polypetillous corolla arranged so as to imitate the labiate form. (Rare.)

$\mathbf{L} \overline{\mathbf{A}}^{\prime} \mathbf{B I} \mathbf{U} \mathbf{M}$, the lower lip of a labiate flower. 
LĂC ẼRĀTE, having the margiu deeply cut into irregular seg. ments as if toru. Compare Erose, Ixcised, LaciNiate.

LĂÇ'ẼRĀTED, see LACERATE.

LACH'RYMMFÔRM, see TEARSHAPED.

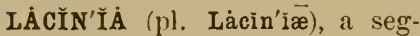
ment of a laciniate leaf.

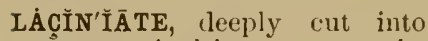
niarrow incisions, more ir. regular and larger than Fimbriate; slashed.

LẢČİN'ǏFôRM, friuge-lilie.

LẢC̆IN' ŪLĀTE, finely laciniate. Compare LACINULose.

LÁC̆́N'ŨLŌSE, laciuulate or bearing little fringes.

LĂCTĚS'ÇENT, resembling or producing milk or latex.

LĂCTǏF'ẼROǓS, produeing or conveying latex; laticiferous.

LĂCTǏF'ẼROŨS VĚS'SĚLS, see LATICIFEROUS YEASELS.

LẢCƯ'NÁ (pl. Làcū'næ), a large deep depression on the surface, or open space between the cells.

LÁCU'NAR, baving, resembling, or pertaining to lacunie.

LĂC'ŪNŌSE, (1) perforated with rather large loles. Compare Foraminated, (2) Having depressions in the surface larger, more irregular, or more irregularly placed than in Alveolate.

LĂC'ŪNŌSE - RƯGŌSE', marked with deep broad irregular wrinkles, as the shell of the waluut or pit of the peach. Compare Runinated.

LÁCŬS'TRǏNE, growing in or on the margins of lakes.

LADDER-CELLS, see SCALARIFORM VESSELS.

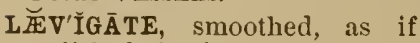
polished; lævis.
L $\bar{E}^{\prime}$ IIS, smooth: having an eren surfice devoid of hair or ronghness of any kind; opposed especially to asperate, striate, sulcate, or any unevenness. Compare Nitid and GLABrous.

LȦG' $\bar{E}^{\prime}$ N ÍFôRM, shaped like a Florence flask (the orclinary bulbous tlask of ehemists). The term bottle-slinped meaus the same, or nearly the same.

LĂM'EL, see LAMELLA.

LA்MĚL'LA் (pl. Láměl'læ), diminutive of Lamina; a thin plate. as one of the "gills" beneath the eap of a mushroom.

LĂM'ĔLLATTE, composed of thin plates or scales; lamellose.

LÁMĔL'LÍFôRM, in the form of a plate or scale.

LĂM'ĚLLŌSE, see LAMELLATE.

LĂM'ĨNA (pl. Lăm'iñ), the blade of a leaf or limb of a petal or sepil.

LĂM'ǏNĀTĔD, consisting of plistes, scales, or layer's; plated.

LĂM'ǏNĀTĔD BǓLB, see TUN1CATED BULB.

L $\overline{\mathbf{A}}^{\prime} \mathbf{N} \overline{\mathbf{A}} \mathrm{TE}$, covered with long curled hairs like wool; lanose; lanuginous; woolly.

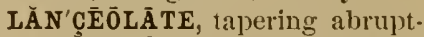
by toward the base and gratually toward the apex, like the head of a lance.

LANCE-0VATE, between lauceolate and ovate, but approaching nearer the latter.

L'A'N ŌSE, see LANATE.

LẢNU'GĬNOǓS, see LANATE.

LĂP'ǏDŌSE, growing in stony places.

LĂPPĀ'CEOǓS, bur-like.

LÄR'VAL STATE, resting state, as the sphacelium of ergot. (W. G. Smith.) Seldom used. 
LĀSĨōCÄR'POǓS, haring pubescent fruit.

L $\bar{A}^{\prime}$ TENT, remaining dormant beyond the usual time, or until called into growtl by some particular stimulus.

L'A'TENT BŬD, see Dormant Bud and Adventitious Bud.

LA'TENT PÉ'RÍODD, see DORmant State and Resting PeIrIOD.

LĂT'ẼRAL, attached to the side of an organ.

LĂT'ẼRAL, n., a side branch or root.

LĂT'ẼRAL BŬD, one situated on the side of a branch, usually in the axil of a leaf. Compare Terminal Bud.

LĂT'ẼRAL DËHǏS'CENÇE, when the opening of au anther takes place upon one or both sides, instead of on the surface facing or' opposite to the pistil.

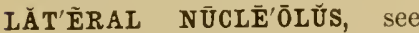
Parandeleoles.

LĂT'ẼRAL NŪ'CLĒŬS, see PARANUCLEUS,

LĂT'ẼRAL PLĀNE, of a flower or other lateral structure, it plane passing from side to side at right angles to the median plane. The lateral plane of a leaf, for example, would pass between its upper and lower surfaces.

L $\overline{\mathrm{A}}^{\prime} \mathrm{TEKX}$, a viseid milky fluid found in certain plants, as the lettuce. See LA'TIC1FERous VESSELS.

LA $\bar{A}^{\prime} T E ̌ X ~ T U B E S$, see LATICIFEROCS VESSELS.

LĂTÍCIF'ẼROŬS VĔS'SĚLS, special anastomosing tubes containing the latex in such plants as have milky juice; latex tubes.
LĂTǏFōLǏ̆TE, having broad leaves. Compare strexopiYlLOES and AXGUSTIFOLIATE.

LĂTIYFŌ'LIOOŬS, see LATIFOLIATE

LĂTİSĚP'TĀTE, laving a broad septum or partition;-applied to pericarps. Compare ANGUSTISEPTATE.

LĂT'TÍÇED, see Clathrate.

LĂT'TÍÇED CELL, see SIEVETUBE.

LĂX, loose: the opposite of close or crowded. An intlorescence may be lu.x because its pedicels are flaccid or sleuder.

LEAD'ER, the upper portion of the primiry stem of a tree, or a central upright brancla which extends beyond the rest of the head

LEAF, an appendage to the stem, definite in position, and usu. ally expanderl to receive air and light. Besides leaves of the usual forms which serve as foliage there are other forms for additional purposes, including those which form the various parts of a flower. See Phyllone.

LĒAF-ĂRRĀNGE'MENT, s e e Phyllotaxis.

LEAF-BLĀDE, the expanded portion of ordinary leaves; lamina.

LËAF-BŬD, a bud which immediately upon expansion produces leaves only. Compare Flowe13-BUD.

LEAF-C $\bar{Y}^{\prime} C L E$, the course of a spiral from the insertion of a leaf through that of intermediate ones to the insertion of the next leaf directly above or below the place of starting.

LEAF-GREEN， see CHLOROPHYLL.

LEA AF'LĚT, one of the divisions or blades of a compound leaf. Leaflets are often articulated 
to the common petiole, and in order to be distinguished from segments they must themselves have distinct petioles, lowever short.

LEAF-SCÄR, the place on a stem from which a leaf lias fallen.

LEAF-SHËAT, see SHEATH.

LEAF-STALK, see Petiole.

LEA AF-TĚN'DRILL, a tendril which is a transformed leaf or part of a leit.

LEAF-TRĀÇE, a fibrovascular bundle, or collection of bundles, while on its passage from the fibrovascular system of the stem to the leat.

LĚATH'ĚRY̆, see CORIACEOUS.

LEFT. The left margin of a leaf, petal, or other foliar organ is the one upon llse left hand as its stem is held downwald or toward the observer and the organ is viewed upon the upper or inner surface. The left side of a lateral thower is the side upon the left band as the observer stands in flont with the stem erect and the flower between him and the main ixis. See remarks under Dextrorse.

LËGITT'ǏMĀTE FẼRTǏLIZA' TION, fertizliation in the usual or natural manner, eitler close or cross fertilization, whichever in the particular case occurs in nature.

LĔG'UME, the fruit of the Leguminosæ. It is mouocarpellary, with the seeds attached to the ventral sirle, and usually monolocular and dehiscent into two valves by ventral and dorsal sutures. The pea and bean are examples. Compare LoMENT.

LEG $\bar{U}^{\prime} \mathbf{M}$ INOǓS, bearing legumes, or relating to plants of the order Leguminosæ.
LEI0-, a prefix from the Greek, meaning smooth.

L $\breve{E} N^{\prime}$ TÍÇĔLS, small ilevelopments of cork at particular points on the surface of many kinds of stems. They appear during the first season's growth, and in some cases, at least, originate beneath the stomata. They probably aid in the transfer of gases and aqeuous vapor.

LĚNTǏÇĚLLE', see LENTICEL.

LĚNTǏC'ŪLÁ (pl. Lěntǐc'ūlæ), see LENTICEL.

LENTÍC'ÜLAR, in the form of a double convex lens; lentiform.

LĔN'TǏFÔRM, see LENTICULAR.

L ĽNTĬG'ǏNŌSE, see LENTIGINoes.

LĚNTÍG'ǏNOǓs, covered with small dots, like dust, scurf, or freckles; lentiginose.

LËP'AL, a rudimentary sterile stamen, or organ supposed to be such, usually in the form of a nectar-gland or petaloid scale; glaud of the torus. See STAMINodium.

LEPĂN'THǏ $\mathbf{M}$, an old term for a petal which contains a nectary.

L.ËP'IDĒS, epidermal scales of various kiuds, especially when attached at the centre. Compare RAMENTA.

LĚP'ĪDŌTE, scaly; scurfy; leprous; leprose.

L.̌̌P'RŌSE, see LEPIDOTE.

LĚP'ROǓs, see LEPIDOTE.

LÉP'TÁ-, or LĚP'Tō-, a prefix from the Greek, meaning small, thin, or slender.

LĚP'TŌME, see PHLö̈м. Applied by Potonie to the phloem-like portion of the fibrovascular bundle in vas- 
cular cryptogams. Compare HADRONE.

L Е̌PTŌPHLŌ'ĔM, a term applied by Vaizey to a portion of the central fasciele or strand in the seta of Polytrichaeex (iu mosses) which he considers to be rudimeutary phloèm.

LĚPTŌPHY̌L'LOǓS, having sealelike leaves.

LĚPTŌSPŌRĂN'ǴǏŬM, a sporangium derived from a single epidermal cell, as in the true ferns, in distinction from one derived from a group of epidermal cells (eusporangium), as in the Ophioglossaceæ and Marattiacex.

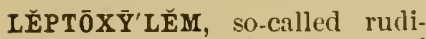
meutary xylem in the seta of Polytrichacea. (Vaizey.)

LEU., or LEUCO, a prefix from the Greek, meaning white.

LEŪCĂN'THOǓS, white-flowered. LEŨ'CITTE, see LEUCOPLAST.

LEU'CODPLĂST, a colorless protoplasmie granule (plastid) such as those in which stareh originates; stareh-builder: leucoplastid; amidoplast; anaplast; leucite proper. See Plastid.

LĚ $V^{\prime} \breve{I G A T E}$, see LÆVIGATE.

LE' $\mathbf{E}$ IS, see LÆVIS.

LI'ĀNE, a woody climbing or twining plant of considerable size; applied only to those which abound in some tropical forests.

$\mathbf{L} \overline{\mathbf{I}}^{\prime} \mathbf{B} \tilde{\mathbf{E}} \mathbf{R}$, the inner layer of bark. consisting chiefly of the phloèm of the fibrovascular system and therefore containing the basttissue; bast.

LI'BRǏFôRM CELL, a narrow thick-walled cell of woody tissue resembling bast; woodfibre.

LID, see OPERCULUM.
LID-CELLS, terminal cells of the neck in some archegonia which for a time close the eanal; stigmatic cells.

LIFE-C $\bar{Y}^{\prime}$ CLE, the course of development from any given stage, as the spore or seed, back to the same stage again.

LIG'NẼoŭS, woody, or pertaining to wood.

LIGNIFǏCA $\bar{A}^{\prime} T I O N$, the process of becoming eonverted into wood; sclerosis.

I IG'NINE, a seeondary deposit, forming the greater part of the bulk of ordinary wood. It contains less oxygen than cellulose, and according to Payen has the formula $\mathrm{C}_{35} \mathrm{H}_{24} \mathrm{O}_{20}$. It is also written Lignin, and is the same as Sclerogreu.

L ĬG'NŬM, see WOOD.

LĬG'ŪLA் (pl. Lĭg'ūlæ), see LIGULE.

IÍG'ŪLĀTE, (1) having a ligule; (2) strap-shaped, i.e., linear and about four to six times as loug as broad.

IÍG'ŨLĀTE FLŌ'RĚT, one of the marginal flowers of a head in Compositæ, bearing a ligulate or strap-shaped corolla; rayfloret. Compare TUBULAR Floret.

IǏG'ŪLE, (1) a strap-shaped corolla in Compositre, such as those on the outer margin of the head in most sun-flowers; (2) a membranous appeudage on the inver side of the leaf in many grasses and some other endogens at the top of the sheath.

LIGGÜLIFLŌ'ROǓs, said of a liead of flowers in Composita whieh contains ligulate flowers only, as in Chicory. 
LIMB, the expanded portion of a petal or sepal. Compare BLADE and Border.

LIM'BĀTE, see BORDERED.

Iİ'BŬS, border, blade, or limb. (Obs.)

LIMIITITYG CELL, see HETERoCYST.

LINE, one twelfth of an inch.

LIN'EAR, very narrow, with the margins parallel or nearly so.

LIN' $\overline{\mathbf{E}} \bar{A} T E$, marked witlı fine parallel lines, especially of color. Compare Striate and Acrot. LATED.

LIN' $\overline{\mathbf{E}} \overline{\mathrm{O}} \mathrm{L} \overline{\mathrm{A} T E}$, diminutive of Lineate.

LINN'GU Æ̌F̂RM, see ToNGUESHAPED.

LINN'GUIFÔRM, see ToNGUESHAPED.

LINN'GŪLĀTE, see ToNGUESHAPED.

LI'NINE, a term proposed by Schwarz and adopted by Strasburger (1888) for the substance of the hyaloplasmic filaments of the nucleus in a state of repose.

LINN of classification devised by Linneus, founded upon the number and arrangement of the stameus and pistils; sexual system.

LIP, (1) one of the divisions (especially the lower) of a labiate calyx or corollil; (2) the labellum in orchids.

LIPǑX'ENOǓS, said of a parasite which leaves its host and completes its development inde. penciently at the expense of the reserve material appro. priated from the host. (De Bary.) Compare Mletcecrous.

LIPPED, see LABIATE. Applied in pomology to the cavity of an apple when a broad projection of the flesh protrudes against the stem. Compare FOLDED.

LİŘLL'LA (pl. Lirel'læ), a linear sessile apothecium in lichens.

IǏTHǑPH'ǏLOǓs, see SAxICOLOU'S.

LITH'ŌCÄRP, see CARPOLITE.

LǏTH'0̄ÇY̌ST, a cell containing a cystolith.

LǏTHŌSPẼR'MOǓS, having very hard seeds.

IITT'TōRAL, growing upon shores, especially upon the seil-shore between tide-marks. Compare Marine.

LIV'ĬD, lead-color; bluish brown or gray.

LŌ'BĀTE, lobed; said of a leaf the margin of which is divided about to the middle into round. ed parts with broad sinuses.

LŌBE, a rounded portion of a leaf or petal; any division of a leaf larger than a tooth which is not a leaflet.

IŌBED, see LOBATE.

LŎB' ŪLĀTE, having small lobes.

LǑB'ULE, a small lobe.

IŌÇĚL'LĀTE, having small or secondary cavities (locelli).

IŌÇĚL'LŬS (pl. Lōçęl'lī), diminutive of Loculus; a little cavity. Used by some in the sense of Loculus for a compartment in an ovary or anther.

LǑC'ÛLȦMENT, see LocuLUs.

LŏC'ŪLAR, having a cavity or cavities; loculose.

LǑCÜLǏCI'DAL, d e h is cen t throughout the middle of the back of each cell at a dorsal suture. Compare SEP. TICIDAL.

LǑC'ŪLŌSE, locular; cellular; especially, having numerous cav. 
ities, as the pith of poke, $P h y$ tolacca decandra.

LǑc'ŪLOǓs, see LOCULAR.

Lŏc'ÛLŬS (pl. Lǒc'ūlì), the cell of an ovary, anther, or similar cavity.

LōcǓs'TA், see SPIKELET.

LōDÍC'ǓLA் (pl. Lōdĭc'ūlæ), see LODICULE.

LǑD'ICŬLE, one of the small scales at the base of the grain between the stamens and palet of many grasses.

LŌ'MENT, a jointed or plurilocular legume formed by spurious transverse dissepiments, as in Desmodium. Some loments are articulated aud separable at the septa or pseudo-septa between the seeds.

LŌMĚNTÁ $\bar{A}^{\prime}$ ÇEOÚS, bearing or re. sembling a loment.

LŌMĚN'TÜM, see LOMENT.

LǑNǴĬTÜ'DǏNAL SY̌S'TĔM, an obsolete term for fibrovascular system.

LO' $\bar{O}^{\prime} \mathbf{A} T E$, haviug the form of a thong or strap: ligulate; linear. Compare Flabellifory.

LU' $\bar{U}^{\prime}$ BRĬCOǓs, slippery.

LU'ÇID, clear. Often used in the seuse of Nitid.

LŬM'BRICCAL, about the shape of an earth-worm. Compare VerMICULAR.

L $\bar{U}^{\prime} \mathbf{M} \check{E} N$ (pl. Lū'mı̀na), the cavity of a cell or filament, or any part or spot which seems to emit light.

LU'NAR, (1) pertaining to the moon; (2) in the form of a half-moon or crescent, as a lunar spot upon a leaf; semilunar; semilunate. Compare LUNATE.

LU $\bar{U}^{\prime} \mathbf{N A T E}$, said of au organ having the form of a half-moon or crescent, or which is marked with one or more spots of that form, as a lunate leaf. Compare LUNAR.

LU' $\bar{U}^{\prime} \mathbf{N} \bar{A} T$ ĔD, having lunar markings; lunate.

LU'NǏFôRM, half-moon or crescent shaped; lunate.

LU' $\bar{U}^{\prime} \mathbf{U} \mathbf{L} \bar{A} T E$, diminutive of Lunate.

LU'́PŨLINE, a yellow waxy pow. der resembling pollen, upon the scales of the hop, containing the active principle, which is bitter, aromatic, and tonic.

IŪPŪL' $\bar{I}^{\prime}$ NOǓS, resembling a head or cone of hops.

LU'RĬD, diugy brown.

LŪTĚS'ÇENT, yellowish.

LŨ'TÊŬ, bright orange yellow. Compare Flavus.

LỸ்ŏT'RŌPAL, see LYcotroPOUS.

LȲCǒT'RŌPOǓs, said of an otherwise orthotropous ovule which is curved like a horseshoe.

IY̌MPHĂT'Íc, clear, like water; not clouded: said, for example, of ordinary plant-hairs containing clear cell-fluid in distinction from those which are glandular, in which the cellcontents are usually granular and turbid.

LY $\mathbf{R A} T E$, pinnatificl, with the lobes decreasing in size toward the base.

L '̌ $\mathbf{R A ̄ T E L Y ̌ ~ P I N ' N A T E , ~ p i u n a t e , ~}$ with the pinnæe decreasing in size toward the base of the leaf.

IȲRE-SHAPED, see LYRATE.

LY̌SĬGENĔT'ǏC, see LYsIGENIC.

IY̌sǏĞÉN'ÍC, formed by the disorganization of cells: applied to the formation of certain intercellular spaces which originate by the breaking down of contiguous cells; lysigenetic; 
lysigenous. Compare SchizoGEXIC.

LY̌SǏG'ENOǓS, see LYSIGENIC.

MĂCRĂN'DROǓS, having large or elongated male plants in algæ.

MACRO-, large or long.

MĂCRŌČĚPH'ȦLOǓS, a term sometimes applied to embryos which have the cotyledons very large and consolidated, as in horse-chestnut. Compare MAACROPODUUS.

MĂCRŌGŌNǏD'ǏŬM (pl. Măcrōgōnĭd'ía), see MACrospore.

MÄCRŎPH'Y̌LLOŬS, having long or large leaves.

MÄCRǑP'ŌDOǓS, a term of little importance applied to a leaf having a long petiole, or to an embryo, chiefly in monocotyledons, having a large radicle.

MĂCRŌSPŌRĂN'GYǓM, a sporangium containing macrospores; megasporangium; oösporangium.

MĂC'RŌSPŌRE, a female or archegonium-bearing spore in some vascular cryptogams. The macrospores are larger than the male or microspores.

MĂCRŌSPŌ'RŌPHY̌L, the leaf bearing the macrosporangium in the heterosporous Ptericlophyta. It is the homologue of the carpel in flowering plants.

MĂCRŌSTY'́LOŬS, applied to heterostylous flowers with long styles and short filaments. Sce remark under Microstylous.

MĂC'ŨLÄTE, spotted or blotched; maculose.

MĂCŪLÁ'TION, the pattern or arrangement of the spots upon a plant.

MĂC'ŨLŌSE, see MIACULATE.

MAIDEN (Hort.), a ter'm sometimes applied to a tree or other plant of one year's growth from the bud or graft. Also applied to any plant which has not fruited, and in forestry to a seedling in distinction from a tree which has sprung from an old root or stub.

MĂL'ẢCOID, mucilaginous.

MALE, bearing stamens only; staminate; bearing only male organs of whatever kind, or pertaining to iudividuals which bear them.

MALE FLOWER, staminate flower.

MĂLPĬGHǏĀ'ÇEOŬS HAIRS, stellitte hairs attached by their middle, as in the order Malpighiacex.

MĂLPĬG'HǏAN ǦĚLLȘ, palisadelike cells in which one or more light lines are present, found in the seed-coats of Leguminosæ, Malvaceæ, etc.

MǍM'MǏFÔRM, breast-shaped.

MẢMMÍL'Ĺ் (pl. Mảmmil'læ), a small nipple or teat-like prominence, as on some pollen-grains. Mare short and obtuse than Papilla. The term is sometimes applied to the apex of the nucleus of an ovule.

MĂM'MÍLLĀTE, nipple-shaped, or bearing mamnillæ. Compare Papililate.

MĂM'MǏLLĂTĚD, bearing mammillæ.

MĂM'MŌSE, breast-shaped, or bearing breast-shaped promineuces.

MĂN'ǏCĀTE, having a coating of entangled hairs. which may be removed entire. Compare Floccose and Pannose.

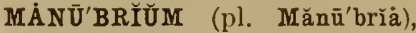
a cylinarical cell which projects inward from the centre of each of the eight shields composing the wall of the globule in Characeæ. 'The manu- 
bria support the apparatus which contains the antherozoids.

MÄR'BLED, covered with faint irregular wide stripes, or traversed by vein-like markings like those which oceur in eertain kinds of marble; marmorate.

MÄRÇÉS'CENT, withering but not falling off, as the corolla of lobelia.

MÄR'GINAL VEIL, in Hymenomycetes (mushrooms, ete.), a membrane stretehing from the margin of the pileus to the surface of the stipe in the young sporophore and covering the hymenium; velum partiale.

MÄR'ĞINĀTE, having a margin differing in texture, form, or color from the remuinder of the surface; margined; edged.

MÄR'Ǵ́INED, see MARGINATE.

MÁRINE', growing in the sea or upon the immediate sea-shore. Compare LitToral and MARITIME.

MĂR'ǏTǏME, growing upon or near the sea-shore.

MÄR'MŌRĀTE, see MARBLED.

MÁSKED, see Personate.

MĂS'SŪLÁ (pl. Măs'sūlæ), one of the lumps of mucilage derived from the disorganized tapetum of the microsporangium of Azolla and enclosing a number of spores. Also applied to an adherent group of pollen-graius derived from a single mother-cell, as the ultimate groups in a pollen-mass in orchids, each containing four grains.

MẢST, a popular name for the fruit of the oak, chestnut, beech, and some other forest trees.
MĂs'ToID, large tèat-shaped. (Rare.)

MÁ'TRIX, the place or body upon or within which anytling grows.

MĂTTŬL'LA, the fibrous material at the base of the petioles of palıns; reticulum.

MĂTŪRĚS'ÇENT, approaching maturity.

MÀTŨT'́ I'NAL, pertaining to the morning; expanding in the morning, as the flowers of morning-glory.

MẼL'Y̌, see FARINACEOUS.

ME'́DIAL, pertaining to the middle; mediau.

ME'DǏAN, see MEdIAL.

ME'DĬAN LINE, a line along the centre or axis of a bilateral organ, as along the midrib of a leaf.

MÉ'DǏAN PLANE of a flower or other lateral structure, the same as antero-posterior plane, i.e., a vertical plane which bisects an organ iuto right and left halves. The median plane of a leaf would pass througl the midrib above and below. Compare Lateral Plane.

MÉDǓL'LÁ, pith; also central tissue of some other kinds, as of the thallus in lichens.

MĚ $D^{\prime}$ ǓLAR $\bar{Y}$, pertaining to medulla or pith.

MĚD'ǓLLĀRỲ RAYS, vertical plates of cellular tissue in the tibrovascular system of exogens connecting the pitl and the cortex. They form the glistening spots called "silver" grain" which are seen on the surface of wood which is split radially. Only the rays formed the tirst season extend entirely to the pith. See $\mathrm{Xr}$ LEM RAY and PHLÖ̈I RAY. 
MĚD'ǓLLĀRY̌ SHEATH, the ring of primary xylem bundles which project into the pith. Compare Cortical SHeath.

MĔD'ǓLLĀRY̆ SYS'TEM, a term sometimes applied to the whole fuudamental system, but usually, and more properiy, employed to inclnde only the pith and medullary rays, or fundamental tissue withiu the cortex.

MĚD'ŬLLŌSE, pith-like.

MĚGẢLōGōNĪD'ǏŬM, see MACROSPOLE.

M ĔGÁRHY' ZOǓS, large-rooted.

MĔGÁSPŌRĂN'GǏUM, see MACROSPORANGIUM.

MĚG'ȦSPŌRE, see MACROsPorE.

MEI'ŌPHY̌LLY̌, the suppression of one or more leaves or foliar organs in a whorl; mioplyylly. It differ's from Abortion in the fact that the suppressed organs have never started to grow.

MEĪŌSTĚM'ŌNOǓs, haviug fewer stamens than petals. This is its usual meaning. Compare ISOSTEMONOUS.

MEI'ŌTĂXỸ, the complete suppression of a whole set of orgaus, as all of the corolla or all of the stamens.

MĚLȦNŌSPẼRM'OǓS, h a vi n g dark-colored seeds or spores.

MĚLLIF'ẼROǓS, honey-bearing.

MÉL'ON-SHĀPED, ovil, with depressed lines running from end to end, as in most muskmelons.

MĚLT'ING, easily dissolving in the moulh, or under slight pressure. A descriptive character in certain varieties of pears.

MĚM'BẼR, a term employed to designate any part of a plant when treated with reference to its position and fundamental structure, but not with refer- ence to function. Thus, all leaves are one and the same nember, though they may be developed in different ways to form different organs. Compare ORGAN.

MĚMBRÀNA'CEOŬS, see MEMBRANOUS.

MĚM'BRĀNE, a very thin expanded tissue, serving the purpose of separation or protection.

MĚMBRĀ'NĒoŬs, see MEMBRANOUS.

MĚM'BRȦNOǓS, thin, soft, and usually translucent, like a membiane. Compare ScaRIOUS.

MENIS'CoID, shaped like a meniscus or concavo-convex lens.

M ĚN'TŬM, a forward projection of the foot of the column in some orchids.

MĚR'ÍCÄRP, one of the carpids or ripened carpels of a schizocarp, especially one of the halves of the cremocarp in Umbelliferæ; diachænium; hemicarp.

MĚR'ǏDISK, a name proposed by Clos for any process upon the receptacle, aside from the floral organs, whether glaudular or not. See LEPAL.

MĚR̆ŠMĂT'ǏC, dividing into parts by the formation of septa.

MĚR'ǏSPŌRE, one of the cells of a compound spore.

MĚR'ǏSTĚM, tissue in an early condition or nascent state while the cells are still undergoing cell-division, as in cambium; formative tissue; generating tissne.

MEL'ǏSTĚM， PRIMARY， see Primary Meristem.

MĚR'ǏSTĚM, SECONDARY， see Secondary Meristem. 
MĚRǏSTĒMǍT'ǏC, consisting of meristem.

MĚR'ǏTHĂLL, SEe INTERNODE.

MĚRİTHĂL'LUัS (obs.), see IN. TERXODE.

MĚRŌBLĂSTĬC, applied to the formation of the embryo from a part only of the oösphere, as in some Gymuosperms.

MĚS'ŌBLĂST (obs.), see $\mathrm{N}$ CLEUS.

MĚS'ÖCÄRP, the middle layer of a pericarp when distinguishable into three layers. This layer is sometimes dereloped as a sarcocarp. Applied mainly to stone-fruits.

MĚS'0̄EIIL, the central part of the labellum in such orchids as have that organ separated into three distinct portions.

MÉSŌPHLE'ŬM, the middle or green layer of the bark, beitween the liber and the outer (usually dry) epiphlcum or corky layer; cellular-eurelope.

MÉS'0̄PHY̌LL, all the fundamental tissue of a leaf within the epidermis.

MĚSŌPHY̌L'LŬM, see MEsoPIIYLL.

MẼSǑPH'Y̌TŬM (obs.), see CoLLAR. Also applied by Lindley to the line of demircation hetween iuternode and petiole.

MĚS'ŌSPẼRM, see SECUNDINE.

MĚS'ŌSPŌRE, the middle cont of a spore when there are three.

MĚSōSTY'LOŬS, having styles of intermediate length in heterostyled plints.

MĚSŌTHĒ'ÇĬŬM, the central of the three layers of cells in the coat of an immature antlier; fibrous layer. The cells of this layer have anuular thickenings. In the mature anther the proper endothecium has often disappeared, leaving the mesothecium as the inner layer, which is theu usually called endlothecium.

ME'TOME, a term applied by Schweudener to tibroviscular tissue on functional grounds, in distiuction from cortical tissue, which (serving for support chiefly) he termed stereome. Strictly, howerer, the term mestome refers only to the essential or conductive portion of a bundle, the bundlesheath being strengthening tissue and therefore stereome.

MẼTĂB'DLLIșM, the chemical changes which take place in a plant in the process of growth; metastasis; transmutation. It includes both Anabolism and Catabolism.

MĚTÁGE of sexual individuals by nonsexual means, either directly or through intervening sexless generations; alternation of generations; polymorplism.

MĚTẢKINE'SǏs, that part of the metaphases in karyokinesis which includes only the separation of the threads.

MĚT'ẢMẼR, applied by Sachs to a Plyton (which see), or one of any number of similar parts connected in a series.

MĔTẢMÔR'PHŌSǏs, the varied derelopment of members of the same morphological value, resulting from their adaptation to different fuuctions. Compare Traxsformation.

MĚT'ÁPHĀŠĚS, a term applied by Strasburger to those portious of kiryolinesis which include the longitndinul splitting of the threads. the for mation of the mother-star, and the subsequent separation of 
the segments to form the daughter-stars.

MĚT'ÁPLĂȘM, a name giren by Hanstein to that part of the protoplasm which holds the formative material. Used by some syuonymously with Del1toplasm.

MẼTÁSPẼR'MOǓs, see AxGIOSPERMOL'S.

MẼTĂS'TȦSǏs, see METABuLisM.

METẼ̄óR'ǏC, applied to flowers whose openiug or closing is influenced by the weather.

İETTE'ÇIOǓS, see H.ETERCECIOUS.

MẼT $\bar{E}^{\prime}$ ÇŠSM, see HETERECISM.

MẼTõX'ẼNOǓs, see HETERECIOUS.

MİĂȘMĂT'ǏC, pertaining to infectivus organisus floating in the atmosphere. See INFECTION.

MĪÇĚL'LA (pl. Miçěl læ̈), a term proposed by Nägeli for certain structural particles which serve for the building up of all plant and animal tissues. They are considered to be aggregations of molecules which, like crystals, are able to increase or diminish in size without chemical change.

MİCRĂN'DRE, see DTARF-NIALE.

MI'CRŌBE, a micro-ol'ganism, animal or vegetable. In use restricted chiefly to plants, especially the Schizomycetes, or bacteria and their allies. See NicrophrTE.

M $\bar{I}^{\prime} C R \bar{O} C \breve{Y} S T$, a resting state of certain swarm-cells in Myxomycetes.

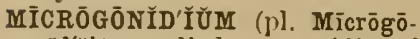
nid'ía), applied to goniclia of smaller size than others produced by the same species;-they are usually male gonidia. as the so-called androspores of
Edogonium. In pteridophytes and their allies they are usually called microspores. See Microspore.

MĨCRŎG'RÄPHY̌, the description or study of microscopic objects; micrology.

MĪCRŌPHY̌L'LOǓs, having small leaves.

MI'CRŌPHȲTE, any plant, such as the bacteria aud smaller species of fungi. which cau be clearly seen ouly by means of a micruscope.

MI'CRŌPÝLE, the nearly closed foramen as it exists in the ripened seed.

MĪCRōsō'MẢ (pl. Micrōsō'mátä), a name proposed by Strasburger for a class of grauules in the protoplasm which have a high degree of refringeucy aud are deeply staiued by hamatoxylin.

MĨCRŌSPŌRĂN'GIUUM (pl. Mīcrōspōrăn'ǵiả), a sporangium containing microspores.

MI'CRŌSPŌRE, a small male spore, as in Rhizocarpæ, Selaginellæ, and Isoetæ. See IIICRogonidicu. Com pare Macrospore.

MII'CRŌSTŌME, a small mouth or orifice.

MİCRÖSTY' LOǓs, applied to that form in heterostyled plants in which the flowers lave short styles and long filaments. The expressions "long-styled," "nedium- or mid-styled," and "short-styled" are preferable to Macrostylous, Mesostylous, and Microstylous, and are more frequently used.

MĪCRŌZŌōGōNǏD'ǏŬM, a motile nicrogonidium, as in Clothrix, differiug from a macrozoögonidium in size and in having the power of conjugation. 
MI'́CRŌZȲME, a microscopic organism capable of producing fermentation.

MǏD'DLE IA்M ĚL'LA், the portion of a lignified cell-wall which occupies the place of the primary membrane. It usually appears as a fine dividing line between adjoining cells. Compare Middle Lamina.

MĬD'DLE IAM'ǏNÁ, the portion of a lignified cell-wall between the middle lamella and the inner lamina.

MID RÍB, the large central vein of a leaf, which usually exists as a ridge continuous with the petiole.

MĬLK, see LATEX.

MǏLK-SĂC, a form of laticiferous vessel existing in some species of maple.

MǏLK-SĂP, see LATEX.

MǏLK-VĚS'SĔL, see LATiCIFER. ot' VESSEL.

MĪMĚT'ÍC, pertaining to minicry.

MǏM'ǏCRY̆, special resemblance to another object, serviug usually for protection, as when plants bear a marked resemblance in color to the soil in dry regions, thus being less liable to be seen and eaten by animals.

MǏN'ǏĀTE, vermilion-colored.

MI'ŌPHY̌LLY̌, see MEıOPHYLLY. MĪōSTĚM'ōNOǓs, see MEIOSTEMoxots.

MİTō'sǏc, pertaining to, characterized by, or exhibiting mitosis; mitotic.

MITT̄'sÍs, (1) the splitting of the chromatin of the nucleus (karyomitosis) or the subdivision of any minute granular bolly found in protoplasm; (2) a figure occurring during mitosis as a result of that process.
MİTŏT'ǏC, see Mrtosic.

MI'TRE-SHĀPED, see MITRIForir.

MǏT'RǏFôRM, conical and slightly narrowed toward the mouth like a pope's mitre. Also the same as Cucullate, but not slit upon one side; mitre-shaped.

MǏXED INFLŌRĚS'ÇENCE, one in which each partial inflorescence develops in a reverse order from that of the geueral inflorescence, as in Compositæ where the general inflorescence is usually centrifugal, the terminal "Hower" opening first, while each head is centripetal, the marginal florets being first developed.

MǏXED VĚSSĔLȘ, those having thickenings in their walls of more than one kind, as both spiral and annular thickenings.

Mō'BǏLE, movable.

MŏL'LISs, soft.

MǑNẢDEL'PHOǓs, having the filaments free, and united in a ring around the pistil, as in most Malvaceæ.

MŌNĂN'DROǓS, having but a single stamen.

MŌNÂN'THOǓs, having but one flower upon a plant or peduncle.

MŎNAS'TẼR, see MOTHER-STAR.

MŌNE'ÇIOǓs, see MoNacioUs.

MON'GREL, properly, a cross. Usually applied in the United States to iuferior mixed breeds resulting from unknown or heterogeneous crossing.

MŌNǏL'ÍFôRM, necklace-shaped; cylindrical, and coutracted at regular intervals so as to resemble a string of beads. Compare Nodose.

MONO-, a Greek prefix, meaniug one or single. 


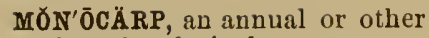
plant that fruits but once.

Mð̌NŌCÄR'PĔLLĀRY̌, of one carpel; monogynous.

MŌNŌCÄR'PİAN, see MoNocarPIC.

MðNōCÄR'PǏC, bearing fruit but once. Compare Polycarpic.

MŏNŌCÄR'POŬs, said of a flower in which the gynceium forms but one ovary, whether simple or compound. Compare PolyCARPOUS.

MǑNŌÇĚL'LŪLAR, see UNICELLULAR.

MǑNŏČ̌H'ẢLOǓs, in single heads, or having one head. Applied to an ovary with but one style, or to flowers disposed in single umbels or other clusters.

MŏNō€HĀ'sǏAL, in single dichasia. Ste Dichasium and ComPOUND DICHASIUM.

MǑNō€HĀ'SĬŬM, a uniparous cyme. Compare Dichasiun.

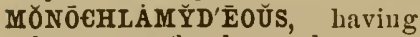
but one floral envelope or perianth-whorl. As this is usually clearly a calyx, and as in doubtful cases it is considered so, the term is often equivalent to A petalous. Compare ACHLAM YDEOUS.

MŌNŌEHRŌ MǏC, see UNICOLOR.

MŌNŎC'LINOǓS, see HERMAPHRODITE. Compare Diclinous.

MŎNŌCǑTY̌LĚD'ONOǓS, having but one cotyledon or seed. leaf. A term applied to endogens.

MONōçY̌C'LǏc, of a single whorl. MŌNEE'ÇOǓs, having stamens and pistils in separate flowers on the same plant.

MŌN $\overline{E^{\prime}}$ ÇIOǓSLY̌ PŌLY̌G'ÀMOǓS, having perfect and separated flowers on the same plant.
Compare Diæciously PolygAMOUS.

MŌNŎG'AMOǓS, see HoMOGAMOUS.

MōNǒG'Y̌NoǓs, having but one pistil or style. There may be several carpels.

MŌNŌI'COǓs (obs.), see MONECIOUS.

MŌNŌLǑC'ŨLAR, see UNILOCULAR.

MōNǒM'ẼROǓs, of one part, as a flower having but one organ of each kind, one pistil, one stamen, etc.; applied also to tubers having but one internode.

MǑNŌPĚT'ALOŨS, sEe GANOPETALOUS.

MŌNŌPHY̌L'LOŬS, see GAMOPHYLLOUS.

MǑN'ŌPŌDE, see MIoNopodiuM.

MǑNŌPŌD'ǏLL, laving a single main axis, as ordinary plants. Compare SrMpodial and Dichotomou's.

MǑNŌPŌ'DY̌UM, an axis of growth which continues to elongate at the apex, while lateral structures of like kind are produced beneath it in acropetal succession. Compare SympoDIUM and Dichotomy.

MŌNǑP'TẼROǓS, one-winged.

MǑNŌSĚP'ALOǓS, see GAMOSEPALOUS.

MǑNŌSİ'PHǑNOǓs, said of a frond in Florideæ when it consists of but a single row of cells.

MONNŌSPẼR'MOǓS, one - seeded. Compare Polyspermous.

MŌNOð'TǏ€HOŬS, in one vertical rank.

MóNōSTY'LOǓS, having but one style.

MǑNŌSY̌MMĚT'RǏCAL, capable of division in but one direction into similar balves, as the 
flower of the pea; zygomorphous. Compare SxMmetRical and Polysyanetrical.

MǑNŌTHĂL'ȦMOǓs, unilocular; applied to galls and rarely (Tuckerman) to the apothecia of lichens.

MŏNōTHĂL'MǏc, derived from a single flower, as ordiuary fruits. Compare Polytilalmic.

MŏNōTY̌Y'ǏC, said of a genus which contains but one species, or of the species itself in such a case.

MóN'STẼR, a plant or animal having any marked abnormal development in form: monstrosity. See SPorT and TERATOLOGY.

MŎNSTRŎ'ǏTY̌, see MoxsTER.

MóN'STROǓs, developed in a remarkably abuormal manner. The term has no reference to size,

MŎP-HĔAD ĚD, said of a tree without a leader aud with an unusually large number of small branches.

MôRPHōĞEN'ẼS̆s, the production of morphological characters.

MŏRPHǑL' $0 ̄ G Y$, the science of the homologies and metamorphoses of members. It treats, for exanuple, of the different forms which leaves assume in different plants. and in the same plant to serve different purposes.

MÓS' $\mathbf{E H A}$ TE, having an odor like that of musk.

MOTHER-CELL, one from which another is derived.

MOTHER-STÄR, a stage of kaIyokinesis in which the nuclear threads lie in the equator of the nucleus, usually in the form of loops, with their free ends pointing away from the centre; monaster; nuclear disk; nuclear plate; equatorial plate.

MǑT'TLED, covered with partially confluent dots, or with blotches of varying intensity. Applied mainly to fruits.

MOUN'TAINOǓS, see AlpesTRINE.

MOVE'MENTS OF VĀRIA'TION (Peffer), see Allassotonic Movenents.

MŨÇ̌L'ǏNOǓS, mould-like.

MŨ'CILĀGE, dissolved vegetable jelly; any slimy vegetable product.

MŨCĬLĂǴ'INOŬS, slimy, or y ielding mucilage; mucous.

MŪ'COǓs, see MrcilagiNous.

MŨ'CRō, a short sharp point.

MÚ'CRŌNĀTE, terminating abruptly in a short stiti point.

MŪCRǑN'ŪLĀTE, diminutive of Mucronate; endiug abruptly in a minute stiff point.

MÜLE, see Hrbrid. The term Mule is by some restricted to geuus-hybrids and by others to sterile hylurids of any origiv. The term is now useless in botany.

MǓLTĂN'GŪLAR, having more than four angles; polygonal.

MŬLTÍ-, a Latin prefix denoting many.

MǓLTǏÇİ'ǏTAL, many-headed; applied to a root or root-stock from which several stems arise.

MŬLTǏCǑS'TĀTE, having many ribs proceeding from the base of the leaf.

MŬLTĬCŬS'PǏDĀTE, having many cusps or points.

MŬLTǏDĚN'TĀTE, having many teeth.

MǓLTIFĀ'RǏoǓS, (1) diversified, or composed of many diverse parts; (2) arranged in many ranks or rows. 
MUัLTǏF'ĚROǓs, producing fruit several times in a season.

MŬL'TǏFǏD, cnt about half way to the midrib into many segments; many-cleft.

MŬLTǏFLŌ'ROǓs, many-flowered.

MŬLTÍFŌLǏĀTE, having numerous leatlets.

MƯLTĬJŪ'GĀTE, having mauy pairs of leaflets.

MŬLTĬLĂT'ẼRAL, many-siđed.

MŬLTĬLŎC'ŨLAR, many-celled: applied maiuly to ovaries or pericarps.

MƯLTĬLŎC'ŪLAR SPŌRE, see COMPOUND SPORE.

MŬLTǏNƯ'CLĒATE, having more than one nucleus in a cell.

MŬLTÍPÄR'TİTE, divided into many parts.

MŬL'TÍPLE, compound.

MŬL'TǏPLE CŌRŏL'LA่, one having more than one whorl of petals, as in "double" flowers.

MǓL'TǏPLE FRƯIT, see COLLECTIVE FRUIT.

MỨL'TǏPLE - PR I'MĀRY̌ ROOT, oue having several main divisions from the crown, as the fascicled root of dahlia.

MŬL'TǏPLǏCĀTE FLOW'ER, see DOUBle Flower.

MŬLTǏRA'DÍĀTE, having many rays.

MǓLTǏRẢMŌSE', having many branches.

MŬLTǏSÉP'TĀTE, having numerons septa.

MǓLTǏsE'RǏAL, in several horizontal rows. Compare MULTISTICHOUS.

MŬLTǏs'TǏєHoǓs, in several or many vertical rows.

MU'RAL, growing upon walls.
MUU'RǏCĀTE, covered with short, sharp points. Compare SCABRous.

MŪRÍC'ŪLĀTE, slightly muricate.

MŨ'RIFÔRM, arranged like courses of bricks or stones in a wall, as the cells in medullary rays.

MŬSCĂR'ÍFÔRM， having long hairs toward the end like an aucient fly-flap, as the styles of some Compositæ. Compare AsPergilliform.

MǓS'ÇIF̂̂RM, moss-like.

MǓSCǑL'ŌGY̆, see BRYoLOGY.

MUU'TǏCOǓs, pointless; blunt. Mainly in distinction from Awned or Mucrouate.

MÜ'TÜALǏSM, see SYMBIosis.

MŪ'TUAAL PĂRẢSI'TǏSM, see SYMBiosis.

MỸCE'LİAL STRÃND, see FIBROUS $M$ YCELIUM.

$M \bar{Y} \mathbf{C} \bar{E}^{\prime} L \check{I} \breve{U} M$, the vegetative portion of a fuugus. consisting of one or more liyphr.

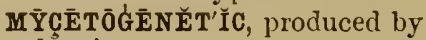
fungi.

MỸ CETTÖGĒNĚT'ǏC MĚTẢMôR' PHOOSǏs, deformation due to a parasitic fungus.

MỸÇĒTǑ́LŌGÝ, see MYCOLOGY.

MȲCŏL'ŌGYY, the botany of fungi.

MỸCOPPRŌ'TẼ̌N, a term sometimes applied to the peculiar protoplasm of which the putrefactive bacteria are composed.

MȲCōRRHI'ZA், a term applied by Frauk to a symbiotic relation supposed to exist between the roots of many plants and the mycelium of certain fungi in soils containing a large amount of humus.

$\mathbf{M Y} \mathbf{Y} \mathbf{C}$ 'sİs, the presence of parasitic fungi in a plant or animal, 
together with the morbid effects of their presence.

MỸCōPRŌTẼǏN, a ter'm sometimes applied to the peculiar protoplasm of which the putrefactive bicteria are composed.

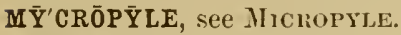

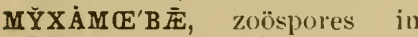
Myxomycetes having an anoboid or creeping motion.

MY̌X'ŌSPŌRE, a spore produced in the midst of a gelatinous mass without distinct ascus or basiclium.

$\mathbf{N A}$ 'KĔD, destitute of the usual covering, as a cell without a wall, a stem without leaves, a Hower without floral envelopes.

NA'KĔD-SEEDED, see GraroSPERMOUS.

NÁNĂN DROǓS, having short or dwarf male plants. Applied to certain algæe.

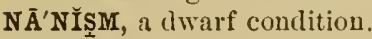

NA'NŬS, dwarf. Compare HuMILIS.

NA'ǍrFôRM, turnip-shaped; i.e., depressed-globose and tapering below, like most varieties of turnip.

NĂS'CENT, in the earliest rudimentary condition.

NĂS'ÇENT TǏS'SŪE, see MERISTEM.

NA'TANT, floating unattached in or upon water. Compare FuulTANT.

NĂT ÜRAL GRẢFT'ǏNG, see INARCHIXF.

NĂT'ŪRALİZED, introduced from another country, but fully es. tablished, growing and repro. ducing itself spontaneously. Conipare ADventitious.

NĂT'ÜRAL ÔR'DÊR, see ORDER.

NĂT'ÜRAL SY̌Y'TĚM, the system of classitication introduced by
A. L. de Jussieu and now in general use, which takes into account all parts of the plant, and seeks to place each species or other group nearest to those which in all respects it most resembles. Compare ArTiFICIAL SYSTEM.

NAUU'TǏFôRM, see NAVICULAR.

NÁVÍC'ÜLAR, boat - shaped, or lilie the hull of a ship, as the glumes of many grasses: uilviculoid: nantiform; crubieform; crmbiforn; scaphoid.

NẢVİC'ŪLOID, see NAVICULAR.

NĚB'ŪLŌSE, clonded.

NĔCK, the line of junstion between root and stem (collar); the upper tapering end of a br:1b; the Darrow part of a pear. toward the base: the upper end of the sheathing petiole in grasses; the upper part of the tube of a gamopetalous corolla (throat); the prolonged apex of a pyrenocarp; the outer portion of au archegonium containing the caual, etc.

NĔCK'LĀCE-SHĀPED, see MIONILIFORM.

NECRǑG'ẼNOǓS, bastening or producing death. A term formerly applied to certaiu parasitic fungi.

NĔC'TAR, a sweet secretion by some pirt of a flower.

NĚC'TAR-GUIDE, a term applied to various color-marlis on tlow ers which seem designed to indicate to inseets the locality of the nectar; nectar-spot; nectarmirk; honey-gruicle; honeyspot; pathtiuder.

NĔCTARǏF'ẼROŬS, secretiug nectar, or having a nectary.

NĚCTÁ' $\bar{A}^{\prime}$ ŬM, see NEctART.

NĔC'TAR-MÄRK, see NECTARGUIDE. 
NĔCTARŌTH $\bar{E}^{\prime} \mathbf{C A}$, a spur or other receptacle contaiuing a nectary. (Obs.)

NĔC'TAR-SPǑT, see NEC'TARGUIDE.

NĔC'TÁR̆, the part of a flower which secretes nectar. Applied especially to spur-slsaped appendinges to the petals contaiving vectar, as in the columbine, and sometimes used for similar organs which contain no uectar.

NEE'DLE-SHĀPED, see ACERosE and ACICULAR.

NĚG'ȦTǏVE GĒ̄ōT'RōPǏș, see APOGEOTROPISM.

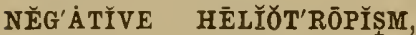
SEe APIIELIOTROPISU.

NĚG'ẢTǏVELY HELǏ̃̄TRǑP'ǏC, see APHELIOTROPIC.

NĚG'ÁTǏVELY RHĒŌTRǑP'ǏC, said of an organ (usually a root) when it tends to grow in a direction opposite to that of a current of water in which it is placed, as the roots of maize. (Jönsson.)

NEM ȦTHĒ ÇĬŬM (pl. Němáthē' çià), a wart-like group or mass of tetraspores in Floridex.

NĚM'ȦTOID, thread-like; filamentous.

N' $\bar{E}^{\prime} \mathbf{M} \overline{\mathbf{E}} O \mathrm{USS}^{\prime}$, composed of threads or tilaments; filamentose. (Obs.)

NĚM'0̄RŌSE, growing in groves.

NEPH'ROID, see RENIFORI.

NẼRV'ÃTE, see NERVED.

NẼRVA'TION, tlue manner in which the nerves of a leaf are arranged; venation.

NẼRVE, a ter'm formerly in general use for the veius of mono. cotyledons, now maiuly used for the veius (when moderately developed) on the floral euve- lopes of grasses. Compare VEIx and Ris.

NẼRVED, having nerves instead of veins; nervite.

NẼRVŌSE', aboutuding in nerves.

NEST'LING, sce NiDULANT.

NĚT'TẼ, SCe RETICULATED.

NEŪRÁt'TION, see NERTATION.

NEU'TẼR, having neither sta. mens nor pistils; neutral. Said of a plaut or flower.

NEU't'TRL, see Neuter.

NEW SPE'CIES. A species is con. sidlered new when its name aud description are published for the first time. The botanical name is then followed by the words " new species," or their abbreviation (" $\mathrm{n}, \mathrm{s}$, " or " n. sp." in English, "sp. nov." in Latiu), without the name of the author, the writer of the description being understood to be the author of the name. When the name is republished in any manuer the species is no longer considered new, and the name of its author is then appended.

NǏD'ÛLĂNT, embedded in pulp or other loose material, or partly enclosed in a receptacle; nestling.

NI'́ŬS, a suitable place for a spore or seed to germinate.

$\mathbf{N} \bar{I}^{\prime} \mathbf{G} \tilde{E} R$, black and either glistening or slightly tinged with gray. Compare ATER.

NİGRĚS'ÇENT, becoming black or blackish; nigricant.

NǏG'RǏCĂNT, see NiGREsCENT.

NǏT'ÍD, smooth and shining; bright; lustrous. Compare LUCID and Levigate.

NǏT'ǏDǓS, see NiTID.

NIV'ẼŬS, snow - white; pure white. A clearer and purer white than Candidus. 
NŏCTÛR'NAL, lasting through a night, or occurriug at vight.

NǑD'DǏNG, see CERNous.

NōDE, the place on a stem where one, two, or more leaves are attached; any knot or swelling; a point of intersection, as of threads in reticulated protoplasm.

NōDǏF'ĚRoǓs, bearing nodes.

NŌDŌSE', knotted; with swollen joints; swollen at intervals. Compare MlowiIfifurir.

NŏD'ŪLE, a small knot or rounded body.

NŏD'ŪLŌSE, diminutive of Noclose.

NôR'MAL, according to rule; usual; of the ordinary type or structure.

NŌSŌL'ŌĞYY, VEGETABLE, see Vegetable Nosology.

Nó'TÁTE, marked by colored spots or lines.

NŌTŌRHI'ZAL, see INCLMBENT.

NÖ'TŌTRİBE, sairl of an irregular flower when arranged so that the pollen from the stamens strikes the back of a visiting insect. Compare STERNoTRIBE and Plecliotribe.

NŪCẢMĚNTĀ'CEOǓS, nut - like, or pertaining to nuts.

NÜCA்MĚN'TŬM (obs.), s e e ANENT.

NƯÇELLLƯs, the nucleus of an ovule.

NŪÇǏF'ẼROǓs, nut-bearing.

NŨ'ÇIFôRM, nut-shaped; nucamentaceous.

NU'CLEAR, pertaining to a nucleus.

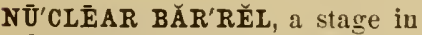
karyokinesis, immediately preceding the nuclear spindle.

NŪCLẼAR DǏSK, see MoTUERSTAR.
NU'CLẼAR FI'BRǏLS, see SPINDLE-FIBRES.

NÜ'CLEAR FIL'ÁMENT, a general term for the chromatin of a nucleus, which in karyokinesis appears ats segments of a filament, and in the resting state as a filamentous netrork; chromatic filament. See Chromosome.

NU'CLEAR PLĀTE, see MothHERSTAR.

NU'CLEAR SPINN'DLE, a spindleshaped achromatic figure in the nucleus during cell-division, consisting of slender filiments which cross the equator or extend towird it from the poles. It begins to appear in the skein stage, and is completed in the mother-star stage.

NU'CLEAR STÄR, see AsTER.

NU'CLẼAR THRĔADS, see SPINDLE-FIBRES.

NU'CLĒATÉ, having a nucleus.

NU'CLẼ ÍN, usually enuployed in the sense of chromatin. By some anthors there is believed to be a distinct chemical substance, a form of protoplasm, which is termed nucleiu.

NŪ CLĒōLĀTĚD, having a nucleolus.

NŪ'CLĒ̄LE, see NUCLEorus.

NŪCLĒ'ōLǓS (pl. Nūclēōlī), any distinct body of considerable size within a uucleus-not a definite and constant organic structure. There may be more than one.

NŪ'CLĒOPLĂSM, the more fluid protoplasm of the nucleus between the nuclear threads; liaryoplasm.

NŪ'CLẼ ǓS, (1) an orgauized structure within the living cell by meaus of which cell-division takes place. It is usually spherical in form, richer in 
protoplasm, and of higher refractive power than the remaining cell-contents; ( 2 ) the part of the ovule containing the embryo-sac (nucellus); (3) any organic centre, as the lilum of a starch-graiu.

NŪ'CLẼ ŬS OF THE EMBRYO. SAC, see SECONDAliY NuClEUS. NŪCŪLA'NǏUM, a terms sometimes applied to fruits like the medlar which contain several nut-like seeds or carpels.

NU'CŪLE, (1) the female organ in Chara; (2) any small nutlike seed or pericarp.

NŪDE, see NAKED.

NŨDICCAUU'LOUัS, having no leaves on tlie stem.

NU'MẼROǓS, too many to be readily counted; indefinite.

NÛRE (Hort.), a shrub or tree which serves for the temporary protection of a younger tree or plant.

NŬT, the fruit of certain trees aud slirubs, consisting of a hard shell enclosing the seed; -also applied to other small nut-like fruits, as those of Carex, Rumex, and Lithospermum. These latter are more properly called nutlets. See Glass.

NU'T'TANT, see CerNots.

NŨT'́t'TION, the motion of a flower, le:t, or growing stem in following the apparent movement of the sim from east to west during the day; simple nutation. Compare Circumetatiox.

NŬT'LĚT, a small nut, or nutlike seed or fruit, as many acheuia.

NŨTRI'TION includes the absorption, elaboration, distribution, and fual assimilation of plaut-food resulting in growth.

NǓX, see NuT.

NY̌CTŌTRǑP'IC, applied to the movements of organs which occur at vight, or upon the approach of nigh , producing what is called the "sleep" of plants.

NY̌CTǑT'RōPǏsM, the so-calied "sleep" of plants.

OB-, inversely.

ǑBCL $\bar{A}^{\prime} \mathbf{V} \bar{A} T E$, clavate in sluape, but attiched by the large end.

ÖBCŎMPRĚSSED', flattened in the reverse of the ustal direction, as when a legume is filtened so that the dorsal and ventral sutures approach each other. Compare Depressed.

óBCŏN'ÍC, conical, but attached at the apex instead of the base; inversely conical. Also applied improperly in pomology to a fruit which lias the form of a very short or Hattened cone.

ǑBCǑN'ǏCAL, see UBCuxIC.

ǑBCÔR'DATTE, inversely heartshaped, i.e., witl the attachment at the small end.

ŎBDǏPLŌSTĚM'ŌNOÜS, di p]ostemonous, with the stamens of the outer whorl opposite to the petals.

ÖBİM'BRǏCĀTE, (1) lıaving overlapping scales directed downward or backward; (2) haviug the outer scales in an involucre progressively longer than the interior ones.

ÖBLĂN'ÇĒ̄LLATTE, lancenlate in form, but tapering toward the base instead of toward the apex.

О̆BLĀTE', flattened or depressed at the ends or poles. Compare Prolate. 
ǑB'L ǏGĀTE, necessary; essential. Compare Facultatit'e.

ŎB'LIGĀTE-PĂR'ȦSITTE, an organisu to whicb a parasitic life is indispensable for the attainment of its development. Compare Facdltative ParaSITE.

ÖBLÏQUE', (1) occupying a position between horizontal and erect; ( 2$)$ having one sille extencling farther forward than the other; (3) having one sicle more developed than the other, as many leaves and some fruits; unsymmetrical. In pomology, Oblique is used in the second sense only, the third being called Angular.

ŎBLITTẼRÄ'TION, see SUPPRESSION.

ŏB LŏNG, longer than wide, with nearly parallel sides. Compare Oval.

Ŏв0̄VAL, sometimes used improperly for Obovate.

Ово̄'VĀTE, ovate with the attachment at the narrow end.

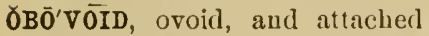
by the small end. Sometimes used incorrectly for somewhat obovate.

ŎB'SŌLĒTE, suppressed, ol very rudimentary; scarcely apparent. See A Bortive.

ǑBTŪSE', having a rounded end or apex; blunt. Com pare ACUTE.

ŎBVĂL'LĀTE, appeariug as though surrounded by a wall.

ŎBVẼRSE', inverse; reverse;-as a leaf which is narrowest at the base.

ǑB'VŌLŪTE, a modification of Convolute in which the entire halves of adjoining organs successively overlap or en fold each other. Half-equitant is one form of this coudition.
ŌÇĔL'LĀTE, see OCELLATED.

ŌÇĔL'LĀTĚD, having a circular patch of color with a spot of another color withiu it like an eje; ocellate; oculate.

ŌçĚL'LŬS, a circular spot, resembling an eye.

ŌEHRÁ $\bar{A}^{\prime}$ ÇEOǓs, browuish jellow; yellowish.

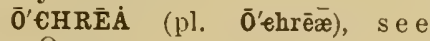
OCREA.

$\overline{0}$ EHRĒĀTE, see OCREATE.

Ǒ€HRŌLEU' COŬS, y e l l o w is h white; whiter than Ochraceous.

$\overline{0}^{\prime} € \mathbf{E} \dot{E} \dot{A}$ (pl. $\overline{0}^{\prime}$ erēæ), a sheath formed by a stipule or pair of stipules united around the stem, as in sycamore.

$\bar{O}^{\prime} \mathbf{E R} \overline{\mathbf{E}} \overline{\mathrm{A}} \mathrm{TE}$, havingु ocrea.

ǑCTĂG'Y̌NOǓS, see OCTOGYNOUS.

ŎCTĂM'ẼROǓS, having the parts in eights, as a flower with eight petals, eight stamens, etc.

ǑCTĂN DROǓs, having eight stamens.

OCTO- (or OCTA-), (from the Greck, ) eight.

ŏCTŏG'Y̌NOǓs, having eight pistils or styles; octagynous.

ठ̌CTŌLǑC'ÜLAR, having eight cells or compartments in a fruit or pericarp.

ǑCTŌPĚT'ALOŬS, having cight petals.

ǑCTŌRĀ'DĪĀTE, having eight rays, as some ligulate flowers.

ŎCTŌSPÊR'MOǓS, eight-seeded.

ŎC'TŌsPōRE, an eight-foll tetraspore. Formerly applied to the oögouium of Fucus vesiculosus, which contains eight oöspheres.

ǑC'TōsPōRoǔs, containing eight spores, as most asci.

ŎC'ŨLĀTE, see OCEILATED.

ŎDD'L Y PINN'NĀTE, see IMPARIPINNATE. 
ŎFFǏÇ '̌NAL, used in medicine or tlie arts.

ǑFF'SĚT, a short lateral branch or stolon proceeding from the base of the plant, which serves or may serve for propagation. It usually takes root of itself. Latern! bulbs are also called offsets.

ǑFF'SH $\overline{00 T}$, an offset, or lateral branch.

OIL-TUBE, see VIITA.

ŌLẼ̆G'ǏNOǓS, oily.

ǑLẼRA' ÇEOǓS, esculent; used for food; applied mainly to garden vegetables.

OLIGGĂN'DROǓs, having few stamens; oligostemonous.

OL'I İGÄRH, applied to a fibrovascular cylínder liaving few rays, i.e., containing or representing few tibrovascular bundles.

రนIIGŌPHY̌L'LOǓs, lıving few, or comparatively few, leaves.

ర̆ǏGŌSPẼR'MOǓS, few-seeded.

రนĬGŌSTĚM ŌNOǓS, see OLIGANDROUS.

రLǏ $\overline{A^{\prime}}$ ÇEOǓs, dusky green.

OMNǏV'ŌROǓs, applied to a parasitic fungus which attacks many kinds of plants.

ŎM'PHẢLŌDE, see OMPHALODIUM.

OัMPHÁLŌ'DǏŬM (pl. Ŏmphảlō dia), the central part of the hilum, containing the vessels which enter the raphe or chalaza.

ONE-SĪD'Ẽ, see SECUND, UNILATERAL, and Homomalous.

ǑNTÓG'ENY̌, the study of the development of an individual through all its stages. Compare PHYLLOGENY.

o'ōçY̌ST, a female orgau or oögo. nium of doubtful nature.
ŌðG'ÁMÝ, the conjugation of gametes which are dissimilar in form. Compare IsogaMx.

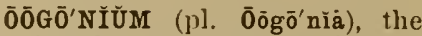
female sexual orgau in Oösporea before fertilization, containing one or more oöspheres, as in Peronospora.

$\overline{0} \overline{0} \cdot \mathbf{N} \bar{U}^{\prime} C L \bar{E} U$ Ŭ, the nucleus of an oösphere. Compare SPERMoNUCLEUS.

$\overline{0}^{\prime} \bar{O}$ PHŌRE, the first or sexual stage or generation in plants having an alternation of generations, as ferns; oöplyte. Compare Sporophore.

ōōPHōRǏD'ǏŬM (pl. ōōphōrǐd'ía) (obs.), see MacrosporangIUM.

O'ŌPHȲTE, see Ö̈PHORE.

Ō'ŌSPẼRM, see OösPORE.

O'ŌSPHĒRE, the oöspore previous to fertilization; i.e., the cell or protoplasmic mass which after fertilization becomes the oöspore.

ŌŌSPŌRĂNĠE, see OÖSPORAXGIUM.

ŌōsPōRĂN'ĞǏUM (pl. ōōspōrăn'g'ià), an old term for oögonium.

O'ŌSPŌRE, a fertilized oösphere; oösperin. As a result of fertilization the oosphere, thus changed to an oöspore, takes on a firm cell-wall and acquires the power of germination.

OPĀQUE', having a dull surface; neither transparent nor shining.

O'PEN, applied to fibrovascular bundles which always contain cambium capable of further growth, as in exogens. Compare Closed.

ŌPẼR'CŪLAR, like an operculum; operculate.

ŌPẼR'CŪLĀTE, having an operculum. Compare DEOPERCuLATE. 
ŌPẼR'CŪLǓM, (1) a trausversely dehiscent lid or cap, like that covering the capsule of many mosses; ( $(2)$ the lid of a pitchershaped leaf.

ŌPǏS'THŌDAL, posterior: applied to the inner or posterior opening of a stoma. Compare EISODAL.

ช̆P'PōšT̃ , opposed in position. Snid, for example, of leaves when situated over agaiust each other in pairs at the same height upon the stem. One floral organ, however, is opposite another when it is superposed to it, i.c.. when it stands between it and the axis. Compare Alternate.

ǑPPóšTI ǏFLŌ'ROǓs, having opposite peduncles.

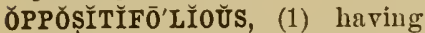
opposite leaves; adversifolious; (2) situated opposite a leaf, as the tendrils in the grape.

○P'PŌȘǏTELY̌-PǏN'NĀTE, having leaflets in pairs.

ÔRBĬC'ÚLAR, circular in outline, or nearly so: orbiculate.

ÔRBǏC'ÚLĀTE, see ORBICULAR.

$\hat{O} \mathbf{R}^{\prime} \mathbf{D E} \mathbf{R}$, a division of a class containing one or more genera; family.

ÔR'DINAL, pertaining to an order.

ÔR GAN, any part having a specinl function, as a leaf or stamen. Compare Mresber.

ÔRGĂN'ǏC ÇĚN'TRE, a point or axis around which growth takes place. It may not remain the mathematical centre.

ÔRGÁNÓG' $\bar{E} N Y$ Y, the origin and development of organs; organogenesis.

ÔRGÁNðG'RẢPHY̌, the study of organs.

ÔRGÄNŌPLĂS'TǏC, having the power of producing organs, as organoplastic tissue.

ÔR'GANS OF RĒPRŌDǓC'TION, those whose chicf function is to serve directly or indirectly in the production of seeds or spores. In the higher plants the stamens and pistils are usually indicated by the tern.

ÔR'GANS OF VĚGETA'T'TION, those which minister to the growth of the whole plant: roots, stem, and leaves.

ŌRǏLNTA'TION, strictly, facing the east. Used in horticulture for the setting of transplanted trees facing the same way as they stood originally. Used in botany for assuming any definite direction with respect to the points of the compass or to the axis of the plant or organ.

ÔR'MŌGŎN, see HorMogoNiUM.

ÔRTHŌPLŌ'ÇEỨ, having con. duplicate cotyledons. (Obs.)

ôRTHŏS'TǏ€HY̌, a vertical row of organs. Compare PARASTICHY.

ÔRTHǑS'TŌMOǓs, having a straight openiug.

ÔRTHǑT'RŌPAL, see ORTHOTRUPOUS.

ÔRTHŌTRŏP'ĬC, growing erect, as stems in contrast with leaves, etc. Compare PlAGIOTROPIC.

ôRTHǑT'RŌPOǓs, (1) applied to an ovule or seed in which the hilum coincides with the chalaza and the micropyle occupies the apex opposite. Compare Anatropous. (2) Applied to the embryo it means the opposite of antitropous, i.e., having the radicle next the hilum, as in anatropons seeds.

Ós'çILLÃTǏNG, see VERSATILE. 
ǑS'M $\mathbf{M} \overline{S E}$, the mutual diffusion of liquids of different densities through a membrane. It is the peculiar property of osmose that the denser fluid absorbs from the ot ber through the membrane more than it gives in exchange. The imbibition of finids by roots is due partially to osmose (endosmose), the fluid within the plant being denser than that in the soil. The outward diffusion of fluid from the plant into the soil, which takes place in a feeble degree, is termed Exosmose.

ర̆SMIŌ'sǏs, see Osırose.

ǑS'SĒOǓS, bony in texture.

Ǒs'SĬFIED, become like bone, as a peach-stone.

Ǒs'TĪōLE, a small orifice, as that in a perithecium for the discharge of spores.

ǑSTI'ŌLL ǓM, see OstTIOLE.

OUT'ẼR GLŪMES, see EMPTY Glumes.

$\bar{O}^{\prime} \mathrm{VAL}$, about twice as long as broad, with regular curved outlines; broadly elliptical.

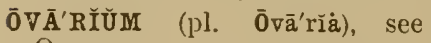
OVARY.

O'VÁRY, the part of a pistil containing the ovules or seeds.

$\overline{0}$ 'VĀTE, like a longitudinal section of an ordinary hen's egg, with the attachment, if any, at the broad end. Compare Orold.

'̄'VIF̂̂RM, see OvoID.

o'voID, of the shape of a hen's egg, and attached, if at all, at the large end. Compare Orate.

$\overline{0}^{\prime} \mathbf{V}$ ULE, the seed previous to fertilization.

ŌVŪLǏF' ẼRoǓs, bearing ovules. O'vŬM (pl. Ō'vá), see OÖSPHERE.
PĂ€HY̌PHY̌L'LOŬS, thick-leaved.

PĂD, a popular name for the leaf of a water-lily.

PĂG'ÎNÁ (pl. Păg'iñ), the surface of an organ, especially the upper or lower surface of a leaf.

PĀINT'ĚD, having color's disposed in streaks of unequal intensity. (Rare.)

PÂIRED, see ConJugatte.

PĀL $\bar{E} \bar{A}^{\prime}$ CEEOǓS, see PALEACEOUS.

PĂL'ĀTE, the convex base of the lower lip of a personate corolla, as in suap-dragon.

PĀLE, see PALET.

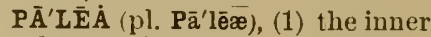
bract of a flower in grasses (palet); (2) one of the bracts or scales upon the receptacle in Compositæ. Also used by some for Raunentum.

PĀLĒ Á'ÇEOǓS, chatf-like; bearing chaff or chaffy scales; consisting of chaff.

PĀLĒōBŏT'ÁNY̌, see FossIL BOTANY.

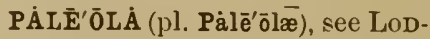
ICULE.

PĀLĒōPHȲTŏL'ōĞY̌, see FossiL BOTANY.

PĂL'ĚT, the inner bract or chaff of a tlower in grasses; formerly known as the upper palet; palea. Compare Gluse.

PĂLǏSĀDE' ÇĚLLS, elongated cells perpendicular to the epidermis in the upper side of most leaves.

PĂLLĚS'ÇENT, somewhat pale.

PĂL'LǏD, pale; wan; deficient in color.

PÄLM, three iuches.

PĂL'MĀTE, lobed or divided so that the sinuses all point toward the apex of the petiole, either moderately as in the maple-leaf, or more deeply, 
when it is sometimes improperly called pedate, or so as to make the leaf compound when it is digitate.

PĂL'MĀTĚD, sec PALMATE.

PĂL'MÄTELY̌ CLĚFT, having the sinuses in a palmate leaf reachjug about half way to the base; palmatifid.

PĂL'MĀTELY̌ CŏM'POUND, havjug the leatlets all attached to the apex of the petiole; digitate.

PĂL MĀTELY̌ DǏVI'D the base in a palmatc manner, but not compound; palmatisect.

PÀL'MĀTELY̌ LŌBED, having the lobes directed toward the apex of the petiole.

PĂL'MĀTELY̌ NẼRVED, sometimes applied to palmately veined leaves in endogens; palm-nerved; palminerved.

PĂL'MĀTELY̌ PÄRT'ĚD, cleft nearly to the base in a palmate manner.

PĂL'MĀTELY̌ VEINED, having the principal veins proceeding from the apex of the petiole, as in palmate leaves; palmveined; palmiveined; radiateveined.

PĂLMĂT'ǏFǏD, see PALMATELT Cleft'.

PĂLMĂT ÍLŌBED, see PALMATELY LOBED.

PĂLMĂTĬPÄR'TĪTE, see PALMATEly PaRTED.

PĂLMĂT'ǏSĔC'T, see PALMATELY DIYIDED. Sometimes improperly used for Palmately Parted.

PĂL'MǏNẼRVED, see PALMATELY Nerved.

PÄLM-NỄRVE, see PALMATELT NERVED.

PÄLM-VEINED, see PALMATELY VEINED.
PĂL'Ũd̆ne, see Palustrine.

PÁLŪ'DĬNOǓS, see PALUstTRINE.

PĂL'ŨDŌSE, see PALUSTRINE.

PÁLǓS'TRĨNE, growing in marshes or swamps; paludine; paludinons; paludose; uliginose; uligiuous.

PĂNCHE, hare pale faint stripes. PĂN'DŨRĀTE, see PANDURIFORM.

PĂNDÜ'RǏEORM, obovate, with oue or two large sinuses or concavities in each side, like the body of a violin; fiddle-shaped.

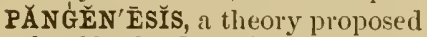
by Charles Darwin to account for the reproduction of every part of an organism. It is, that each separate part of the individual throws off minute reproductive gemmules, which are capable of multiplication, and may be trausuitted from geveration to generation. Spores and seeds are abundantly supplied with these gemmules from all parts of the organism, and therefore specially fitted for reproductiou. If other parts can serve for propagation, it is because gemmules from the remaining parts are present; - if a cutting "strikes root," for example, it is because it contains root gemmules. Atavism is caused by dormaut gemmules from a previous generation. A modification of this theory proposed by De Vries is that each cell contains all the essential elements for the reproduction of the plant, the protoplasm containing a vast uumber of selfreproductive particles (paugens) which trausmit the characters of the individual.

PĂN'ǏCLE, a branched raceme, as in oats. Panicles are either determinate or indeterminate 
in their mode of inflorescence. If the former they are called "cymose;" if the latter, "botryose." They have a valiety of shapes, the typical form being loose and spreading, with repeatedly branched pecluncles, as in mauy grasses. Panicles of certain forms have received special names. A compact panicle like that of lilac is called a thyrsus; a spikeshaped panicle like that of wheat is usually called a spike, or compound spike; a corymb might be called a level-topped centripetal panicle, and a cyme a similar centrifugal panicle.

PĂN'ǏCLED, see PANiculate.

PẢNÍC'ŨLĀTE, resembling a panicle; furnished with panicles; arranged in panicles; panicled.

PẢNǏC'ŨLĀTĚD, see PANICU. LATE.

PẢN ǏC'ŨLIFÔRM, pauicle-shaped.

PĂN'NÁY̌, pertaining to bread; suitable for making bread.

PAN'NǏFôRM, thick and spongy, like coarse cloth.

PÁN'NŌSE, (1) having a felted coat of hairs. Compare Fuoccose aud Manicate. (2) Having the texture of coarse cloth; panniform.

PĂNSPẼR'MĬA, the theory that seeds and spores are every. where preseut, ready to be developed upon favorable op. portunity.

PÁ' PẼRỸ, see ChaRTACEOUs.

PÁPǏLĪō Á'CEOǓS, having flowers, as in the Papilionacer, a tribe of the Leguminose or pea family; i.e., with a large upper or posterior petal called the vexillum, two lateral petals called wings, and two small inferior petals more or less united into a carina or keel.

PẢPǏL'LA் (pl. Pápill'læ), a small soft, elongated teat-shaped protuberance. Compare Mamilla and WART.

PĂP'ǏLLĀRY̌, having or resembling papillæ. Compare VERRUCOSE.

PĂP'ÍLLĀTE, having papillæ; papilliferous. Compare MAMILLATE.

PĂPǏLLǏF'ẼROǓS, see PAPILLATE.

PẢPǏL'LǏFôRM, in the form of a papilla.

PĂP'ǏLLŌSE, papillate or papillary; especially, covered with papillæ.

PĂPPǏF' ẼROǓs, bearing a pappus, as the seeds of thistle.

PĂP'PǏFôRM, like ̊ pappus.

PĂPPŌSE', pappiferous or pappiform.

PĂP'PŬS, the calyx in Compositre, especially when developed in a hairy or feathery mauner to effect the dispersion of the seed. Compare Coma.

PÁP'ūLȦ (pl. Păp'ūlæ), see PAPILIA.

PÁP'ŨLOǓS, see PAPILLOSE.

PĂPY̌RÃ ÇEOǓS, papery; chartaceous.

PÁRÁCōRõL'LÁ, see Crown.

PĂR'ÄČYST, a ter'm proposed by T'ulasue, but not generally adopted, for De Bary's term Pollinodium.

PĂRẢHẼLIǑT'RōPISMM, the power which certaiu leaves have when placed iu bright suulight of placing their surfaces parallel to the rays of light; diurnal sleep. Compare DianeliotROPISM. 
PÁR'ALLĚL NERVED, see PARALLEL VEINED.

PAR'ALLĚL VEINED, having the veius or the principal oues parallel, or merely diverging: opposed to Reticulate veined and characteristic of the veins (or nerves) of endogens. In some exogens, however, as the beech, the principal lateral veins are parallel, but in exogens the term parallel reined is not applied, the condition being expressed in examples like this by the special term pinnately veined.

PÅÁM $\bar{I}^{\prime} T \bar{M} M$, a name given by Flemming to the more fluid portion of the cell-substauce which is contained in the meshes of the mitom or network of threads. It is the paraplasma of Kiupffer.

PĂRẢNÉ'MÁTÁ (sing. Părànē'má), paraphyses among the spores of Fucus and other algæ. (Obs.) See PAiAPHrSEs.

PĂRÁNŨCLẼ'ōLŬs (pl Părànūclēobli), one of the additional or secondary nucleoli in a nucleus, when there are more than one.

PARÁNŪ'CLĒ ǓS (pl. Părảnū'clēī), :u object resembling an addi. tional nucleus-generally adjoining the true moleus and in some cases budded off from it; lateral nucleus.

PARẢPĚT'ALOǓs, standing by the side of al petal, as stamens in some Rosacer.

PARÁPHY̌L'LŬM (pl. Părảphyl'là), a foliaceous expansion which is not a true leaf, as the large stipules of the pea. Especially one of the leaf-like scaly hanrs among the trine leaves in nosses.
PẢ RÃPH'ÝSEȘ (sing. Pảrăph'y̌sǐs), sterile filaments among reproductive bodies of various kinds, as those among the archegowia and autheridia in certain mosses, among the asci in Ascomycetes, and amoug the basidia iu Basidiomycetes.

PAR'ȦsīTE, a plant which grows upon or within another living body, from which it derives a part or the whole of its nour. ishment. Compare SAPRoPHY'TE.

PAR'ȦSITTE - SAX'RŌPHȲTE, a parasite which kills its host, then continues to feed upon it.

PĂRÁSÍT'ÍC CĂSTRA'TION, sterility of a reproductive organ caused by a parasite.

PÁR'ÁSITISTED, affected by a parasite; haviug a parasite growing upon or within it.

PĂR'ȦSITIS̄M, the coudition of being a partusite.

PĂRÁSTÁ $\bar{A}^{\prime} \mathbf{M}$ ĚN, see STAMIÑo. DIUN.

PĂRÁSTÉ'MŎN, see STAMINoDIUN.

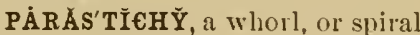
row of organs. Compare URTHOSTICHY.

PĂR'ȦSTỸLE, an abortive style.

PĂRÁTÓN'ǏC, depressing or retarding: opposed to stimulating. Applied mainly 10 certain spontaneous novements of plauts, such as the "sleep" of leaves, induced by the withdrawal of the usual stimulus, in distinction from movements caused by meclianical or artificial irritation. Sometimes applied to all movements of organs which are produced by the presence or absence of external stimuli. The term is also applied to the condition of plants when unu- 
sually insensitive to stimuli of any kind. Compare РнотоTONIC.

PÁŘ̌N'€HY̌MÁ, all tissue composed of cells which do not have tapering extremities. Especially soft cellular tissue like that of pith and the pulp of leaves. Compare ProsenCHYMA and SCLERENCHYMA.

PĂRĚNEHY̌M'ȦTOǓs, pertaining to, containing, or resembling parenchyma; spongy; porous.

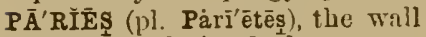
of any enclosing body.

PÁR'́ETAL, belonging to or situated upon the wall, as ovules or seeds upon the wall of the pericarp.

PĂRǏPǏN'NĀTE, see ABRUPTLY Pinnate.

PÁRCE'ÇOǑ́s, liaving male and female "flowers" in mosses placed close together. (Lesquereux and James.)

PÄRT'ÉD, divided nearly to the base.

PÄRTEN sional production of true spores or seels without fertilization. Compare APOGAMY.

PÅR'THĒNŌSPŌRE, a spore in certain ulgae resembling a zygospore, hut produced without conjugation.

PÄR'TIAL, secondary or subordinate.

PÄR'TIAL INN'VŌLŨCRE, oఐe which subtends a subordinate part of an inflorescence, as a partial or secondary umbel.

PÄR'TIAL PĒDǓÑ ${ }^{\prime} C L E$, a branch of an inflorescence (pedicel) bearing more than one flower.

PÄR'TIAL PET'Ǐ of a petiole bearing oue or more leaflets; petiolule.

PÄR'TIAL UัM'BĔL, one of the parts or secondary umbels of a compound umbel; umbellule; umbellet.

PÄRT'İBLE, capable of being readily diviled, but not divid. ing spontaneously.

PÄR'Títe, see PARTED.

PÄRTÍ'TIǑN, see SEPTUM.

PÄR'VǓS, relatively small.

PÁSTEUR' $\mathbf{R}^{\prime}$ SM, a tel'm npplied by some writers to the protective or prophylactic inoculation of the attenuated virus of certain diseases, especially of hydrophobia, as devised by Lomis Pasteur. The older term Vac. cination, however, is being very properly extendeal to all operations involving llis principle. Compare Pasteuizizatyon.

PĂSTEURĬZ $\bar{A}^{\prime}$ TION, the preservation of wines or other fermented liquids by destroying the fungi and their spoles that would produce further and deleterious changes. This is effected by prolonged heating to a moderate degree (about $140^{\circ} \mathrm{F}$.) for the puipose of inducing the germination and subsequent destruction of the spores which are present.

PÁTĚL'LÁ (pl. Pàtèl'læ), a form of sessile apothecium in lichens. (Obs.)

PẢTĚL'Lf̈FôRM, kneepan-shaped; in the form of a watchcrystal or shallow saucer, especially if thickened like a kueepan.

PÁT'ENT, spreading nearly at right angles.

PÁTH'FĨNDẼR, see NECTARGUIDE.

PÁTHŌGĹL'ǏC, disease-producing; pathogenetic.

PẢTHǑL'ŌĞ̛̆, see VEGETABLE Pathologr.

PÁT'ŨLOŬS, slightly spreading. 
PAUCI-, a Latin prefix: few.

PẠUÇİFL Ō'ROǓS, few-flowered.

PEÂR-FÔRM, see PEAR-SHAPED.

PEÂR-SHĀPED, ovoid or obovoid, and contricted at the sides like the Bartlett pear. Compare TEar-shaped.

PĚC'TĨNĀTE, having close narrow divisions like the teeth of a comb. Applied also by De Bary to two series of tibrovascular bundles when the members of each alteruate with those of the other, like the teeth of two combs.

PËD'ĀTE, palmately parted or divided into somewhat linear lobes, with two strong lateral lobes from each of which somewhat linear divisions arise, as in the maidenlatir fern and Viola pedata. Compare PALMATE.

PĚD'ĀTELY̌ CLĚFT, see PEDA'TIFID.

PĚD'ĀTELY̌ VEINED, having no mid-vein, but with two strong lateral veins, from each of which others originate which extend toward the apex; pedatinerved. Compare $\mathrm{PAL}_{\mathrm{AL}}$. mately Veined.

PẼDÁT'ǏFID, divided in a pedate manner about half-way to the base; pedately cleft.

PËDĂT'ĨNẼRVED, see PEDATELY VEINED.

PẼDÁTIPÄR'TİTE, p e da t e ly veined and lobed with the sinuses reaching nearly to the principal veins.

PĚD'ICČLL, a branch of an intlorescence, supporing one or more flowers. Also applied to a little stalk or support of any kind. In orchids it is a portion of the pollinium in some genera which is derived from the rostellum and con- nects the caudicles with the retinaculum. Conpare Footstalk and Peduncle.

PËD'ÍČLLLĀTE, having a pedi. cel; pedicelled.

PĚD'ǏČLLLED, see PEDICELlat'E. PĒDIC' ÚLĀTE, see PEDICELLATE. PẼDÚN'CLE, the stalk of an inflorescence, whether of one flower or more. Compare Pedicel and Partial Pe. DUNCLE.

PẼDŬÑ'Cled, see Peduncu. LATE.

PĒDǓN'CŪLAR, pertaining to or serving as a perluncle; grow. ing upon or attached to the side of a peduncle, as a pedun. cular tendril.

PĒDŨÑ'CŪLĀTE, having a peduncle, as a pedunculate flower or inflorescence: peduncled.

PÉG, a lip or projection at the lower end of the hypocotyl in Cucurbitaceæ which serves in germination to hold the seedcoats down while the cotyledons are withclrawn.

PĒLĀ'Gİan, see Pelagic.

PẼLĂ $\dot{G}^{\prime}$ ÍC, pertaining to the deep sen; widely dispersed through the oceau; pelagian.

PĚL'LǏCLE, a distinct, firm, and in some cases separable, onter layer of the cortex in lichens and some other fleshy fungi.

PĚLLŪ'CYĨD, translucent.

PÉLO'RÍA, a regular condition in flowers which are usually irregular. See Regular and Irregllar Peloria.

PĚL'TÁ (pl. Pèl'tæ), an obsolete term for certain target-shaped apothecia in lichens.

PĚL'TÃTE, shield- or targetshaped; circular, and fixed by the lower surface, especially the centre of it. 
PĚL'TĀTELY̌ VEINED, having veins radiating in all directions from the summit of the petiole, as in a peltate leaf.

PĔL'VÍFôRM, shaped like the cavity of the pelvis; basiushaped. (Rare.) See AcETABULIFORM and COTYLIFORM.

PĚN'ÇĬLED, marked with fine distinct lines as if with a pencil.

PĚN'ÇILLLED, see Pexciled.

PĚND'ENT, hanging directly downward. Compare CERNous aud DroopiNG.

PĚN'DŪLOǓS, hanging downward more than cervous, nearly vertically.

PËNICČĹL'LĀTE, bordered or tipped with fine hairs like those of a camel's-hair pencil. Compare Penciled.

PĚNǏČLL'LIFôRM, like a camel'shair pencil.

PĚN'NĀTE, see PINNATE.

PĚN'NǏFORM, in the form of a feather or plume.

PEN'NǏNẼRVED, see PINNATELY VEINED.

PENTA-, a Greek prefix: five.

PĚNTÁCÄR'PĚLLĀRY̌, having an ovary with five carpels.

PĚNTẢCǑC'COǓS, of five cocci.

PĚNTẢCY̌C'LIC, in five whorls.

PĚNTĂG' 'ỸNOÜS, of five pistils or styles.

PĚNTĂM'ẼROUัS, of five parts: sairl of a flower having tive organs in each whorl. Sometimes written 5-merous.

PĚNTĂN'DROǓS, having five stamens.

PĚNTÁP̌̆T'ALOǓS, of five petals. PĚNTÁPHY̌L'LOǓS, five-leaved; applied maiuly to the parts of the calyx; pentasepalous.

PĚNTĂP'TẼROǓS, five-winged.
PĚNTẢSĚP'ALOŬS, of five sepals; pentaphyllous.

PĚNTA் SPẼR'MOǓS, five-seeded.

PĚNTĂŚTǏHHOǓs, in five vertical rauks.

$\mathbf{P} \bar{E}^{\prime} \mathbf{P} \overline{0}$, a cucurbitaceous fruit, as a melon or gourd. It is indehiscent, theshy, inferior, polycarpellary, and has a thick, more or Jess hardeued, rind.

PĚRẢPHY̌L'LǓM, an accrescent foliaceous calyx, as in quince. (Obs.)

PẼRCǓR'RENT, running throughout, as a millib through the entire length of a leaf to the extreme apex.

PĚRĚN'NǏAL, adj, living more than two years.

PĔRĔN'NĬAL, n., a plant which lives more than two years.

PĚRĚN'NǏAL HẼRB, a plant that lives from year to year, but dies to the ground or nearly so at the close of each season.

PẼR'FĔCT, containing both stamens and pistils; hemmaphrodite; bisexual. Compare ComPLETE.

PẼRF $\bar{O}^{\prime} \bar{L} \overline{\mathrm{I}} \overline{\mathrm{A}} \mathrm{TE}$, said of a leaf which is nuited around the stem at its base. Compare CoNNATE.

PẼR' FōRĀTE, pierced with small round holes. Compare PERTuse and Puxctate.

PẼRGẢM $\overline{\mathbf{E}}^{\prime}$ NẼOŨS, see PERGAMENTACEOUS.

PẼRGÁMĚNTÁ'ÇEOǓs, I i k e parchment. (Rare.) S e e Chartaceous.

P̌̌R'ǏANTH, the calyx and corolla taken togetlier, or calyx alone when there is no corolla. Used mainly where calyx and corolla are much alike, as in lilies. Formerly applied to the 
calyx only, or to caly'x and involucre.

PĔRĬ N'THǏŬM, see PERIANTH. PÉRĬĂTHŌMÁ $\bar{A}^{\prime} \mathbf{N} \check{I} \dot{A}$, an unnatural multiplication of sepals, bracts, etc.

PĚR'ǏBLĔM, the primordial cortex, i.e., the layer of nascent cortex beneath the dermatogen.

PĔRĬCĂM'BĬUัM, see PHLOËMSHEATH.

PĚR' $\breve{Y C A ̈ R P, ~ t h e ~ w a l l ~ o f ~ a ~ r i p e n e d ~}$ ovary or seed-vessel. Sometimes improperly applied to husks or other protective coverings surrounding the fruit.

PER'IEH㐫TH, the involucre of leaves around the base of the seta (or sessile capsule) in mosses; also around the archegonia in Marchantia, etc.; perichatium.

PẼR̆EH更'TIAL, belonging or pertaining to the perichxth.

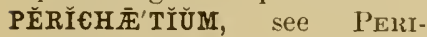
CHATH.

PĚRǏCL $\bar{A}^{\prime} D \check{I} U \mathbf{M}$, a sheathing petiole in exogens, as in many Umbelliferie. (Rare.)

PẼRICLI'NAL, saici of cell-walls or any lines when parallel with the outer surface of the plant or organ. Compare Axticl1NAL. The annual rings of a trunk, for example, extend in a periclinal direction, and the medullary rays in an anticlinal.

PĚRÍCLIN ${ }^{\prime}$ ǏUM, a name for the involucre in Composita.

PĚR'ǏC̄YCLE, the onter portion of the central or fibrovascular cylinder.

PĚR'ǏDẼRM, see EPIPHLEUM. Also applied to the cell-wall or any other enclosing membrane.

PĚRǏDI'ōLǓM (pl. Pěrǐdīōlà), di- minutive of Peridium: a secondily or interior peridium containing a hymenium, as in Crucibulum.

PĒRÍD'ǏŬM (pl. Pērĩd'İà), the covering of almost any closed spore-case, or fungus-fruit, as of a puff-ball.

PĚR'ǏGŌNE, see PEliANTH.

PĚRǏGō'NǏŬM (pl. Pěrĭgōnìà), see Perraxth. Sometimes used for Perichath.

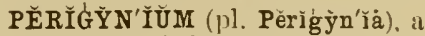
term applied to various appendages of unusual or donbtful character surrounding the pistil, as the sac-like cuvelope (utriculus) surrounding the ovary in Carex. Also used for Perichath in Hepatica and mosses.

PĒRĬG'Y̌NOǓS, adherent to the calyx and free from the ovary: said of stamens.

PĔRĬPĔT'ALOŬS, around the petals.

PĚRǏPHĚR' ǏC, situited around the outsicle or periphery.

PĔRĬPHLŌ'ĚM, see PhLOËMSHEATH.

PĚRǏPHŌRÃN'THǏŬM, see PERICLINIUY.

PĚRĬPHY̌L'LŬM (pl. Pěrīphỳl'là), SeC LODICULE.

PĔR'ǏPLĂ\$̦M, a byaline peripheral layer of protoplasm; ectoplasm. Especially, in Peronospores, a part of the protoplasm in the oögonimm aud antheridium which does not take part in fertilization. Compare Goxoplasur.

PẼRǏP'TẼROǓS, surrounded by a wing-like expansion.

PĚR'ǏSPẼRM, the albumen of a seed, especially that formed outside the embryo-sac. Sometimes applied also to the secel- 
coat and to the pericarp. Compaie ENDosperM.

PĚRǏSPẼR'MǏc, furnisled with perisper'us.

PĚRǏSPŌRĂN'GǏŬM, see INDUSIUM.

PĚR'ǏSPŌRE, a covering of one or more spores, as the cell or sac in which tetraspores are formed.

PĚR' ÍSTŌME, the friuge of teeth around the mouth of the cap)sule in mosses.

PĚRǏTHË'ÇĬŬM (p]. Pěrithē'çià), the receptacle containing the asci in Ascomycetes. Commonly applied in a general way to the whole ascocarp.

PĚrIT'RōPAL, see PERITroPOUs.

PĚRITT'RōPOǓs, having the axis of the seed perpendicular to that of the pericarp. (Rare.)

PĚRǏZO'NÍŬM, a thin nou-silicions membiane of a young auxospore in Diatomacee.

PẼRPĚNDǏC'ŨLAR SY̌S'TĚM, see Fibrovascular System.

PẼRSǏST'ENT, remaining longer than usual, as parts of the flower which remain (either living or dead) until the fruit is ripe, or leaves which die but reviain upon the tree during winter.

PẼR'SÖNĀTE, labiate, with the throat nearly closed by a projection in the lower lip called the palate: masked. Compare RINGENT.

PẼRSFÍRĀ'TION, see TransPIRATION.

PẼRTūs'ĀTE, see Pertuse.

PẼRTŪSE', having slits or holes; perforate.

PẼRtūsed', see Pertuse.

PĚR'ŪLA (pl. Pěr'ūlæ), see PERULE.

PĚR'ŪLĀTE, having perules.
P̌̌R'ƯLE, see BUD-SCALE.

PĔT'AL, a leaf of a corolla; flower-leaf.

PĚT'ALED, having petals; petalous: opposed to Apetalous. Used mainly in compounds, as five-petaled.

PETALIF' ẼROǓs, bearing petals.

PETĂL'ǏFôRM, shrped like a jetil.

PĚT'ALINE, see Petaloid.

PĚT'ALŌDE, an organ resembling a petal; a false petal.

PĒTĂL'ŌDY̌, the conversion of other floral organs into petals.

PĔT'ALOID, petal-like in texture, color, and form; petaline. Compare Corallaceous.

PĚTALŌMĀ'NǏA, any unusual development of the petals. Not usually applied to ordimary doubliug, but to some renuarkable development in size or form.

PĚT'ALOŬS, see Petaled.

PĚT'Í̄LAR, pertaining to ol having a petiole; borne on a petiole, as a petiolar gland or tendril.

PĚT' $̌ \bar{O} \mathbf{L} \bar{A} R \breve{Y}$, pertaining to a petiole.

PĚT'Ǐ̄̄LĀTE, having a petiole; petioled.

PĚT'Ǐ̄̄LE, the stem or foot-stalk of a leaf. Compare STIPE and Peduncle.

PĚT'ĪōLED, see Petiolate.

PĚTǏǑL'ULAR, pertaining to the petiole of a leaflet.

PĚT'ÍōLūLE, see Partial Pet. IOLE.

PEZ'İOID, in the sliape of Peziza: cyathiform, or nearly so.

PH疋ŌÄR'POǓS, having the fruit free from the perianth. (Rare.) 
PH无NŎG'ĀMOǓs, see PHENogaIIOUS.

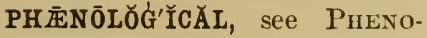
LOGICAL.

PH缡 $\mathbf{0} C ̧ \bar{Y} S T$, an old term for Nucleus.

PHĀ'LĂNX (pl. Phàlăn'gēş), a bundle of more or less coherent stamens with broad filaments, as in some Malvacex. Compare Avelplifa.

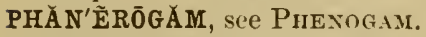

PHĂNẼRŌGA'MĬ AMIOLTS.

PHĂNẼ̃ōGĂM'ǏC, see PhenogANOUTS.

PHĂNẼRŎG'ȦMOǓS, see PIIENoGAyous.

PHĚL'LĚM, cork.

PHĚL'LŌDẼRM, green cells beneath the cork formed from the inner layers of the phellogen; cork-cortex.

PHELL'LÖĞN, the inner active growing layers of cork-tissue; cork-cambium; cork-meristem.

PH.' $\bar{E}^{\prime}$ NŌGĂM, a flowering plant, i.e., one which produces true seeds; phanerogam. Comıare CRYPTOGAM.

PHĚNŌGĀ'MǏAN, see PhENoGAMIOUS.

PHĚNŌGĂM'ǏC, see PhenogAMOUS.

PHẼNŏG'ÁMOǓs, producing true Howers and seeds. Compare CRYPTUAAMOUS.

PHĒNŌLŏG'ǏCAL, applied to the blossoming of plituts, and other periodical phenomena of plants and animals; phruological.

PHLŌĚM, that portion of a fibrovascular bundle which eontaius the bast and sieve tissue; leptome. In exogens it is always sharply defined from the remaining portion (xylem) by a layer of cambium. The inner bark is derived from the phloěm, and the wood from the xylem.

PHLŌ'LM-RÃY, a lay or plate of phloëm between two melullary riys. It is an ontward contiuuatiou of a xylem-ray.

PHLO'ĚM-SHEATH, a layer of thin-walled cells surrounding the fibrovascular eylinder next within the coriex-usually better defined in routs than in stems; bast-sheath; periphloëm; pericaubium; vaseular bundle-sheatl.

PHŌRÀ N'THǏŬM, see ANTHODIUM.

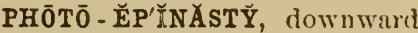
curvatule due to the presence of liglit. C'ompare РнотоHYPONASTY.

PHŌTŌ - HȲ'PŌNĂSTY̌, upwarł curvature due to increased illumiuation. Photo-epinasty and photo-hyponasty should be distinguished from heliotropism, as the curvatures are in the directions stated, from whatever direction the light comes.

PHŌTōTĂX' Ǐs, taking a definite position with refereuce to the iucident rays of light, as certain desmids aud the leaves of the compass-plant, Silphium laciniatum.

PHŌTōTóN'Ǐ́c, a term applied to the stimulating influence of light upon plauts, inducing or increasing irritability and excitability. Thus, when growth which has been arrested by prolonged darkness is restored upon admission of light, the effect is termed the phototonic influence of the light: with most organs, however, growth is more rapid in darkness. This effeet of light in retarding growth is called its pura- 
tonic influence. See Para. TONIC.

PHRĂG'MA் (pl, Phrăg'màtá), a horizontal false dissepiment in a pericarp, as in some species of Cassia. Formerly any fulse dissepiment, or auy dissepimeut.

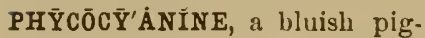
ment, found in certain marive algæ.

PHȲCŌE RY̌TH RǏNE, the reddish pigment in Florideæ.

PHY̌CǑL'ŎGÝ, see ALGOLOGY.

PHÝCO'MA, the whole plant in algæ, including thallus and reproductive organs. (Obs.)

PHȲCōMÁ' TẼ R, gelatine containing spores in algæe. (Obs.)

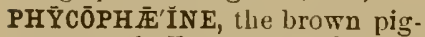
ment of Fucaceæ and some other algæ.

PHȲCŌXÁN'THǏNE, a buff-colored pigment in diatoms and certain other algæ; diatomine.

PHȲ'LÁ, pl., see Phylum.

PHY̌LLÁ'R İES, an old term for the bracts forming the involucre of the flower-head in Composita.

PHY̌L'LŌCLĀDE, see PhylloclaDIUNr.

PHY̌LLŌCLĀ'DǏŬM (pl. Phy̆llōclā'dìa), a flattened branch which somewhat resembles a leaf, as in Ruscus and Psilotum; cladorle; cladodium; cladophyll; phylloclade. Coinpare Phyllodium.

PHY̌LLÖCỸ'ÁNǏN, a bluish pigment which with phylloxanthine forms the green coloring matter of chlorophyll; cyanophyll.

PHY̌L'LŌDE, see Phyllodiom.

PHY̌LLŌ'DǏŬM (pl. Phy̆llō'dìà), a dilated petiole taking the place of a blade.
PHY̌L'LŌDY̌, the reversion of bracts or floral organs to leaves; frondescence; phyllo. morphy.

PHY̌L'LŌĠ̌̃N, see PHYLLO. PHORE.

PHY̌LLōǴ̄ENĚT'ǏC, leaf-producing.

PHY̌LLŏG'ĒNOǓS, glowing upon leaves.

PHY̌L'L $\overline{O I D}$, leaf-like.

PHY̌LLŌMÁ'NİA, an abnormally abundant growth of leaves, or their production in unusual places. Compare PLEIOPHYLLY.

PHY̌L'LŌME, a general term for all orgatus which are morphologically leaves, as bracts, scales, petals, etc.

PHY̌LLǑM'ÍC, pertaining to a leaf or phyllome.

PHY̌L'LŌMÔRPHY̌, see PHrLLODY.

PHY̌L'LŌPHŌRE, anY leaf-bearing organ, especinlly the lenfbearing portion of the stem in palms.

PHY̌LLŌPŌ'DǏ M, the branched or unbranched axis of a leaf, as the stipe and rachis of a frond, an ordinary petiole, or any arrangement which serves as an axis or support for the expanded portion or portions of a leaf.

PHY̌LLŌTAX'Ǐs, the order of arraugement of leaves upon stems; phyllotixy.

PHY̌L'LŌTAXỸ, see PhyLloTAXIS.

PHY̌LLŌXÃN'THǏN, a yellow pigment assuciated with phyllocyanin in the production of chlorophyll; xanthophyll.

PHȲLOG'ENY̌, the comparative study of the development of animals or plants. It seeks to 
trace the origiu of species, varieties, etc., and their various orgaus from preexxistiug forms. It deals will the history of a species or other gromp, in distinction from Ontogeny, which deals with the history of an individual. See Evolution.

PHȲ'LŬM (pl. Phy'lá), a scale, gromp, or system of organisms arrauged in the manner in which its individuals $(\%$ suhordinate groups have succeeded each other in point of tiue.

PHY̌ŠĪōLǑ́'ǏCAL BǑT'ȦNY̌, the science which treats of how plants live, srow, and perform their varions functions; vegetable physiology.

PHȲTŌĞĽN' $\mathbf{E S I S S , ~ p l a n t ~ r e p r o d u c - ~}$ tion, germiuation, and development, or the science which treats of these processes; phytogeny.

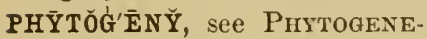
SIS.

PHȲTŌĠĔĞGẢPHY̆, see GEOGKAPHICAL BOTANY.

PHȲTǑG'RẢPHY̌, descriptive botany, iucluding both the describing and naming of plauts. See Vegetable TAXoNomY.

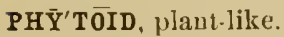

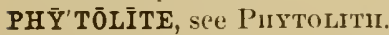

PHY Y'TŌLITH, a fossil petrified plant; phytolite.

PHȲTŌLITTHǒL'ōGY̌, see FossiL BOTANY.

PHȲTŎL'ŌGY̆, see BoTANY.

PHỸTŎL'Y̌š́s, the clıange iu position undergone by the chlorophyll of a cell in consequence of the ulternation of day and night or of the intensity of the sumlight. See A postrophe, Epistrophe, and SYSTRophe.

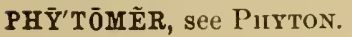

PHȲ'TŏN, an interuode with a node at its upper extremity which bears one or more leaves, in the axil of each of which may appenr one or mole buds; phytomer. The vame was given by Gaudichand, who regarded plants as compound iudividuals made up of successive phytons. See METAMER.

PHȲTǑN'0̄MY̌, see PnYsIOLOGICAL BOTAYY.

PHȲTǑN'Y̌MY̆, see PIIIsIoLOGICAL BUTANY.

PHȲTŌPẢTHǑL'ŌĞY̆, see VEGEtable Pathologr.

PHȲTǑT'0̄MY̌, (1) the science of vegetable anatomy; (2) the art or act of plant-dissection. Compare Stiructural BotANY

PHȲTŌZōón (pl. Phytōzōa) (obs.), see Axtuerozold.

PI'LEATE, like a pileus; having a cap or pileus; pileiform.

PİL'Ǐ́FôRM, shaped like the pileus or cap of a mushroom.

PĪLE'ōLỨS (pl. Pìlēōōì), a little pileus, especially where there are several from the same stem.

PİLĒōRH'̄'ZÁ, see RooT-CAP.

PI'LOǓS, see PILOsE.

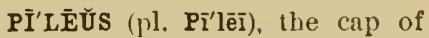
mushrooms. Extended to other similar objects, as the stalked stroma of Claviceps.

PĨLIF' ẼROǓS, bearing hairs.

PǏL'ǏFôRM, hair-like.

PİLIG'ÉEROǓs, producing hairs.

PİL̄sE', (1) covered with long, soft, nearly erect and somewhat distant lairs; (2) having the nature of hair.

Pİ'LƯS (pl. Pī'lī), a hair. 
PǏN-EȲED, a florist's ter'm for certain flowers which have the style more conspicuous than the stamens. Compare ThruMEYED.

PǏN'NA (pl. Pin'næ), a leaflet, or brauch of a piunately-compouud leaf.

PǏN'NĀTE, having leaflets borne aloug a common petiole; pinnately compound. Compare Bipinnate and Tripinnate. See LEAFLE'T.

PǏN'Nātéd, see Pinnate.

PǏN NĀTELY̌ CǑM POUND, see PinNate.

PǏN'NĀTELY̌ CLĚFT, see PINNATIFID.

PǏN'NĀTELY̌ DĒCǑMPOUND', bipinnate, or further divided in a pinuate manuer.

PǏN'NĀTELY̌ DǏVI'DĚD, see PINNATISECT.

PǏN'NĀTELY̌ LŌBED, having several lobes of about the same size on each side of an elongated leaf; pinnatilobate.

PǏN'NĀTELY̌ PÄRT'ĚD, see PINNATIPARTITE.

PǏN'NĀTELY̌ TẼ R'NĀTE, see PinNately Trifoliate.

PǏN'NĀTELY̌ TRĪFo'LǏ̃̄TE, trifoliolate, with at least the terminal leaflet distinctly stalked; pinnately ternate.

PǏN'NĀTELY̌ VEINED, having one primary vein or midrib from which secondary veins run parallel toward the margin, as in the beech; 'featherveined.

PǏNNAT'ÍF̆D, piunately veined with margiual divisions reaching about half-way to the midrib.

PÍNNĂTÍLŌ'BĀTE, see PINNATELY LOBED.
PǏNNĂTǏPÄR'TĪTE, having marginal divisions in a pinuate leaf reaching nearly to the base; pinuately parted.

PǏNNĂT'ǏSĚCT, having the lobes of a pinnate leaf divided to the midrib but not petioled.

PǏN'NIFÔRM, like a feather.

PǏN'NǏNẼRVED, see PINNATELY VEINED.

PǏN'NŪLÁ (pl. Pĭn'nūlæ), see PINNULE.

PǏN'NŪLĀTE, having pinuules,

PÍN'NÜLE, a secondary or other subordinate pinna, as in pinnately compound or pinuately decompound leaves.

PǏP, originally any seed, now sometimes applied to the seeds of the apple and to some other small seeds or seed-like bodies, including the little bulbs of lily-of-the-valley.

PI'SÍFôRM, pea-shaped.

PÍS'TILL, the central seed-bearing organ of a fiower, consistiug of one or more united carpels. It consists of the seed-containing portion called ovary, the pollenreceiving part called stigma, and generally an intervening stem called the style. Usually there is but one pistil in a flower, but when, as in the. straw. berry, there are several distinct bodies as here clescribed seated upon the receptacle, each is properly called a pistil.

PǏS'TĬLLĀRY̌ CôRD, an old and inappropriatc name for the con. ductive tissue of the style. See Conductive Tissue.

PǏS'TǏLLĀTE, said of a flower coutaiviug pistils but no fertile stamens.

PǏSTǏLLĬD'ǏŬM (pl. Pǐstĭllǐd'iả), see Archegonium.

PǏSTǏLLIF'ẼROǓS, bearing pistils, or pistils without stameus. 
PǏS'TILLODDY̆, the transformation of other organs into pistils.

PǏT, (1) a small depression, or a thin spot iu a cell-wall; (2) the endocarp of a drupe containing the kernel or seed; stoue. See Bordered Pit and Bordered Pore.

PǏT-CHĀM'BẼR, the cavity of a borlered pit upou one side of the closing membrane.

PITTCH'ẼR, see AsCIDIUM.

PǏTCH'ẼR-SHĀPED, when applied to a corolla means tubular with a contracted throat, as in Vaccinium; urceolate. A p. plied to other organs it means shaped more or less like an ordinary pitcher with a lip or spout at the top, as the leaf iu the various "picclier-plants."

PITT, the column or cord of soft cellular tissue at the centre of au exogenous stem; medulla.

PǏT'TÉD, marked with small depressious.

PǏT'TĚD VĽS'SĔLS, vessels having thickenings iu the sorm of a network with polygonal meshes, leaving thin spots or pits; dotted ducts. Compare Bordened Pit.

PǏTŪ'ǏTOŬS, pertaiuing to pitch or mucus.

PLACCEN'TA, the part of the ovary to which the ovules are attrched; the tissue from which the sporangia arise in ferus. Compare Hrmenium.

PLACĚNTĀTION, the arrangement of the seeds in the pericarp; the arrangement of the placenta itself.

PLÁČ́N'TǏFôRM, in the form of a double concave lens; i.e., like a circular thickened disk clepressed in the centre upon both sides.
PLĀǴǏ̃̄TRŏP'ǏC, growing at an angle from the vertical or from the axis either upward or downward. Compare ORTHOTROPIC.

PLĀIN, said of a margin which is not undulate in any degree, though it may be sinuate. (E.S. Goff.)

PLĀIT'ĚD, see Plicate.

PLĀNE, flat.

PLĀNE OF İNSẼR'TION, a plane which passes through the point of insertion of a lateral member, as a leaf, aud coincides with the main axis and the axis of the lateral member.

PLĀNE OF SY̌M'METRY̆, any plane which divides an object into symmetrical halves.

PLĂN'ÖGAMETEE, a ciliated or otherwise motile coalescing (sexual) cell; zoögamete.

PLĂNT-CĀNE, a sugar-cane produced directly from seed, in distiuction from Ratoon, which see.

PLÁNTLĔT, a small or young plant.

PLǍNT PA்THǑL'ŌGY̆, see VEGEtable Pathology.

PLĂȘM (or Plăș'mà), see ProtoPLAsy. Also used for nutri. tive cell-Huids of all kinds.

PLĂȘMÁSŌME, a protoplaımic corpuscle.

PLĂȘMĂ T'IC, serving for growtll; plastic. (Rare.)

PLĀșŌ'DǏŬM (pl. Plășmō dỉà), a nuass of uaked multinucleated protoplasm exhibiting amce. boid movement: the vegetative body in Myxomycetes.

PLAȘMŎL'Y̌šs, the contraction of protoplasm under the influence of reagents.

PLĂȘMOLY̌T'ǏC, pertaining to plàsmolysis. 
PLĂS'TǏC, serving the purpose of growth; plasmic; formative.

PLĂS'TǏD, one of a cliss of clearly defined protoplasmic granules iu the protoplasm of active cells which forms the basis of the chlorophyll and other color-gramules, and is also the ceutre at which starchgrains are produced. For the synouymy of the colorless plisstids, see LEuCOPLAsT; aud for that of the color-plastids, see CHROMATOPHORE.

PLĂS'TǏN, see ACIILOMATIN.

PLĂS'TŌD, see RHABDOID.

PLĀTE, see Nuclear Plate and SiEve-PLATE.

PLÁTEAU', the very short stem which bears the scales in a bulb. Formerly called Corm or Cormus. See Consr.

PLĂTY̌CÄR'POǓS, broad-fruited.

PLĂTY̌LŌ'BĀTE, broad-lobed.

PLĂTY̌PHY̌L'LOŬS, broad-leaved.

PLEIO-, a Greek pretix meaning full of, or many.

PLEĪōMôR PHǏsM, (1) a change of form line to excessive growth of an organ; (2) sometimes used in fungi for Poly. morphism.

PLEĪǑPH'Y̌LLOǓS, having leares withont apparent buds or branches in their axils. (Rare.) See Pleiophyily.

PLET'ŌPHY̌LLY̌, a state in which there is an abnormal number of leaves from the same point, or an unusually large number of leaflets in a compound leaf. Compare Poly Pாтік.

PLEĪŌSPẼR'MOǓS, containing an abnormally large number of seeds. Formerly the same as Polyspermous.

PLEI'ŌTĂXY̌, a state in which there are an abnormally large numiber of whorls.

PLE'NŬS, full, applied to " double" flowers.

PLĒōMôR'PHǏSM, see PLEIOMORPHISM.

PLÉ'ŎN, a term proposed by Nïgeli for those aggregates of molecules which cannot be increased or diminished without changing their chemical nature.

PLẼ ŌNASM, haviug any part abnormally numerous. (Rare.)

PLE' RŌME, nascent fibrovascular tissue.

PLE'RŌME -SHĒATH, the phloèmsheath in its uascent state.

PLESǏŌMÔR'PHOǓS, nearly of the same form.

PLEŨRẼN' moody tissue. (Rare.)

PLEŪRŌCÄR'POǓS, see CLADOCAllPOUS.

PLEŪRŌDÍS'COǓS, growing upon the siles of the disk, as the ray. flowers in Compositx.

PLEŨRÖG'Y $\bar{Y}^{\prime} R \bar{A} T E$, having the annulus in ferns placed laterally, as in the genus Trichomanes.

PLEŪRōRHĪ'ZAL, see ACCuMBENT.

PLEU'RŌTRĪBE, said of zygomorphic flowers which have the stamens so placed that an insect entering will receive the pollen upon its side, as in the pea. Compare Nototrine and S'TERNotribe.

PLĚX'ǓS, any network.

PLI'CÁ, see Polycladr.

PLI'CĀTE, folded like a fan.

PLICAT'T'ŨATE, diminutive of Plicate.

PIŪMŌSE', like a feather, as the slender brauches of the pappus 
in thistles, which have a row of fine hairs on each sicle.

PLU'MŨLA், see PluMule.

PLU'MŪLE, the rudimentary stem and leaves between the cotyledous.

PLURI-, a Latin prefix: more than one.

PLŨŘFō'LǏOǓs, several - flowered.

PLŪRIFŌ'LǏĀTE, having several leaves.

PLŪRǏFō'LĪōLĀTE, having several or many leatlets.

PLŨĬLǑC'ŪLAR, having more than one cell in an ovary; multilocular. Compare UN1LOCULAR.

PLŨRIPĚT'ALOǓS, see PoLYPETALOUS.

PLŪRǏSĚP'TĀTE, haviug more than one septum.

PNEU'MȦTŌDEȘ, u p w a r d growths from the roots of palms and some other plauts which assist in aerration. The "knees" of the bald cypress were formerly supposed to be of this character.

PǑC'ÜLIFÔRM, deep cup-shaped, with hemispherical base and nearly npright sides. Compare Alveolate and CAMPANULATE.

PŏD, any dry dehisceut fi'uit; capsule. The term pod is the more popular, and is usually restricted in its use, among botanists as well as others, to capsules of considerable size, especially when somewhat rounded or inflated, as in the milkreed (Asclepias).

PŌDE'TIǏFôRM, resembling a podetium.

PōDĒ'Tř̆M (pl. Pōdētrua), a stalk of an apothecium in lichens.
Also applied to the fruit-stalk in Marchantia.

PŌ'DǏ $M$, a support for some other part. 'The stem, for example, is a podium for the branches. Used mainly in composition. See MoxopoDIUM and STMPODIUM.

PǑDŌCÄR'POǓS, having a gyuophore.

PǑDŌČ̌PH'ÁLOǓs, said of a head of Howers when supported on a distinct peduncle or pedicel.

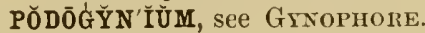
PŌDǑP'TĖROǓS, having winged peduncles.

PǑ'D'0̄SPẼRM, see FuNicuLUs.

POINT'AL, an old term for Pistil. POINT'LĔSS, see MUTICOUS.

POINT'LETÉD, sEe APICULATE.

PŌ'LAR BǑD'Y̌, see Polar CELl.

POLAR CELI, a portion of a gimete budded off prior to fertilization; apoblast; directive corpuscle; polar body; polar globule. Rure in plants.

PŌ'LAR CÔR'PǓSÇLE, a central mass in each aster of a divid. ing nucleus.

PÖ'LAR GLǑB'ŪLE, see PoLAR CELL.

PŌ'LAR NÜ'CLẼ Ǔs, a fourth nucleus in each end of the embryo-sac previous to fertilization. The two polar nuclei unite to form the nucleus of the embryo-sac or " seconckary nucleus."

PōLĂR'ǏTY̌, the state of having distinct poles; the tendency to assume a direction parallel to the poles of the earth, as the leaves of the compass-plant, Sitphium laciniatum.

PŏL'L ĽN, the fertilizing powder, usually yellow, produced in the anthers of flowers. It consists of unicellular grains 
of definite form, varying according to species, which begin the process of fertilization when placed upon the stigma by an act of germination.

PŎL'LĚNĀTE, see PolinNate.

PŎLlĚNA'Tín, see PollinaTION.

PŎL'LĔN-ÇĔLL, sometimes applied to the cells or chambers of the antlier which contain the pollen; pollen-sac.

PŎL'L ĚN-CHĀM'BẼR, in gymnosperms, a cavity at the apex of the ovule in whicl the poliengrains lie during fertilization; pollinic chamber.

PǑL'LĔN-GRĀIN, the usual term for an individual spore, cell, or particle of pollen.

PǑL'LENİZE, see Pollinate.

PŎLLENĬZA'TION, see PoLLINATION.

PŎL'L ĚNOID, userl by Benwett \& Murray for Antherozoid.

PŎL'LEN-MȦsS, see Polliniun.

PŎL'L ĚN-SAC, the cavity of an anther containing the pollen; polleu-cell.

PǑL'LEN-SPŌRE, see POLLENGRAIN.

PŎL'LĚN-TĔTRÄHE'DRǑN （pl. Tětrảhë'drá), see Pollen-TETRAD.

PǑL'LĚN-TĚT'RĂD, a pollenmass consisting of four pollengrains united, either permavently or before fully developel; fourfold pollen-grain; polleu-tetralseclron.

PǑL'LĚN-TÜBE, a thin slender tube which issues from the pollen-grain on its contact with the stigna, which it penetrates until it reaches the ovule where fertilization takes place.

PớL'L ĔX, an iuch. (Obs.)
PǑLLǏNA Á'R ǏŬM (pl. Pŏllīnā'rĭà), see ANTIERIDIUM.

PŎL'LǏNĀTE, to place pollen upon the stigma; polleuate; pollenize.

PǑLLǏNA $\bar{A}^{\prime} T I O ̌ N$, the placing of pollen upon the stigma-the first stage of fertilization; pollenization.

PŏLIǏN'ǏA, pl., see Polliniunr.

PǑLLǏN'ǏC CHĀM'BẼR, see POLLEN-CII AMBE R.

PǑLLǏNǏF'ẼROǓs, pollen - bearing.

PŏLLǏN'ǏŬM (pl, Pŏllǐn'ĩa), a coherent mass of polleu-grains in certain plants, as orchids and milk-weeds, so arranged as to be conveyed by insects; pollen-mass. For the terminol. ogy of the parts supporting $n$ pollinium, see Récinaculum, Corpusculua, Caudicle, aud Pedicel.

PǑLLǏŇŻ̄'TIǑN, see PoLLINATION.

PǑLL INNŌ'DǏUM, the autherimm or male sexuil organ in Pyrenomycetes which, either directly or by means of an outgrowth, conjugates with the female organ in fertilizatiou.

POLY-, a prefix derived flow the Greek, meaning many.

PŎLY̌ẢDĚL'PHǏAN, see POLY. ADELPHOU'S.

PǑLY̌ẢDĚL'PHOǓs, having tlie stamens united by their filaments into three or more sets. See ADElphous, MoNadel. PHoUs, and DIADELPHOUS.

PǑLY̆ĂD'ẼNOǓs, bearing many glauds.

PǑLY̌ĂN'DRĬAN, see POLYANDROUS.

PǑLY̌̆N'DROǓs, having twenty or more liypogynous stamens. Compare Icosandrous. 
PŎLY̆ĂN'THOǓs, having many flowers, especially if in one head. A polyantlious involucre, for example, is one investing many flowers.

PŏLY̌CÄR'PĔLLĀRY̌, said of a pistil consisting of more than one leaf or carpel.

PǑLY̌CÄR'PǏC, fruiting successively; sychnocarpons. Compare MonocarPIC. Sometimes improperly used for Apocarpous.

PǑLY̌CÄR'POǓS, used botlı for Polycarpic and Apocarpous. Compare MLNOCAlipic and MoNOCARPoUs.

PŎLY̌ÇĔPH'ÁLOŬS, bearing many heacls.

PǑLY̌CLĀ'DY̌A, see PoLYClady.

PǑLY̌CLĀ'DOŬS, baving abnormally numerous branches.

PŎL'Y̌CLĀDY̌, an excessive development of twigs or branches; plica. Due either to disease or teratology.

PǑL'Y̌CLŌNY̆, an old term for Polyclady.

PǑLY̌CŎC'COǓS, of several cocci. PǑLY̌CǑTY̌LĚD'ONOǓS, having more than two seed-leaves.

PǑLY̆CŏTY̌LẼD'ర̆NY̆, an abnormal increase in the number of cotyledons.

PǑLY̆DĔL'PHOŬS, see POLYADELPHOUS.

PŎLY̌ĔM'BRY̌X̄NĀTE, h a ving more than one embryo in a seed.

PǑLY̌ĔM'BRY̌ōNY̌, the production, either abnormally or regularly, of more than one enbryo in a seed. The term has been restricted to cases where the additional embryos arise withont fertilization outside the embryo-sac, but there seems to be no good reason for the restriction.
PǑLY̌FLō'ROǓS, see IIULTIFLORous.

RǑLY̌GĀ'MǏAN, see PoLYGANOUS. PǑLY̌GÁMŌ DĪOE'ÇIOǓS, sue DIEECIOUSLY POLYGaMOUS.

PǑLY̌G'ẢMOǓs, producing male and hermaphrodite, or female and hermaphrodite, or male, female, and hermaphrodite flowers on the same or on different individuals; i.e., haviug both perfect flowers and those of one sex.

PðLY̌G'ŌNOǓS, Laving many angles, knots, or nodes.

PŎLY̆ĞYNE'CIAL, containing the gynœcia of several flowers, as a collective fruit.

PǑLY̌G'Y̌NOǓs, having many styles or pistils.

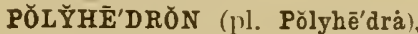
in Hydrodictyon, a special angular cell with horn-like processes, formed by the swarm-cells produced in the zygospore, and within which a new cœnobium is developed.

PŌLY̌M'ẼROǓS, having many parts, or more thau one: said of a flower with more than one organ in each whorl, or of a whorl containing more than one orgat. Compare MIONOMEROUS.

PŏLY̌MIOR'PHǏC, see POLYMOR PHOUS.

PǑLY̌MÔR'PHǏSM, (1) a condition in which different individuals of the same species have differ ent forms, as in many diøecious plants; (2) the state of passing different stages of existence under distinct forms which might be mistaken for different species, as is the case with heterocious and some other fungi; pleiomorphism. See Metagenesis, Altelition 
of Generations, and HetERECISM.

Pð̌LYMôR'PHOǓs, existing under different forms. See above. Also having numerous more or less defiuite sub-types under a given type.

PǑL Y̌PĔT'ALOǓs, having distinct petals (opposed to Gamopetalous); apopetalous; dialypetalous; eleutheropetalous; choripetalous.

PðL'Y̌PHŌRE, a common receptacle for many distinct carpels, as that of the strawberry.

PŌLY̌PH'Y̌LLOŬS, see PoLYSEPALOUS.

POL' Y̌PHY̌LL ̌̆, an increase in the usual number of floral organs in a whorl. Compare Pleiophylity.

PǑLY̌RHI'ZAL, many-rooted.

PŎLY̌SĚP'ALOǓS, of two or more distinct sepals; aposepalous; apophyllous. Compare PoLyPETALOUS.

PðLY̌SI'PHŌNOǓS, said of the thallus in Floridea when it consists of several parallel rows or filaments of cells.

PǑLY̌SPẼR'MOǓS, c ont a in ing many seeds. Compare PleioSPERMOUS.

PðL' Y̌SPẼRMY̌, the fertilization of a female cell by more than one male ceii.

PǑL'Y̌SPŌRE, see COMPOUND SPORE.

PǑLY̌SPŌ'ROǓS, coutaiuing many spores.

PŌLY̌S'TĀEHOǓS, having many spikes.

PǑLY̌STĚM'ŌNOǓS, having many more stamens than petals. Compare Isosteyonous and Polyandrous.

POLY̌SY̌MMĚT'RǏCAL, capable of division into two symmetrical or equal halves in more than one direction; actinomorphous.

PǑL Y̌THĂL'MĬC, derived from more than one Hlower, as a collective fruit. Compare Monothalmic.

P0̄LY̌T'0̄MOǓs, haviug the blade of a leaf distinctly divided into many subordinate parts, but not compound; having the stem forked or divided into many coördinate parts.

PŌLY̌T'RǏ€HOǓs, bearing numerous hairs.

PǑL Y̌ZỸGŌ'SĬS, the conjugation of more than two cells (gametes).

PŌM $\overline{\mathbf{A}}^{\prime}$ CEEOǓs, having the appear. ance or nature of an apple.

PŌME, an indehiscent fruit of more than one carpel, with the seeds enclosed in horny or parchment-like endocarps, and an aduate fleshy calyx, as in the apple.

PŌMǏF'ẼROǓS, pome-bearing.

PŎM'ǏFôRM, apple-shaped.

PōMðL'̄ㅕㅍ, the department of horticulture which relates to fruits. See Fruit. Compare Carpology.

PŌRE, a small circular opening.

PŌRE-CÁNĂL', the passage through a bordered or other pit between adjoining cells.

PŌRE-CĂP'SŪLE, one from which the seeds or spores escape by a pore or pores.

PŌRĔÑ'€HY̌MA (obs.), s e e Pitted Tissue.

PO'́RōSE, pierced with many small circular openings.

PǑRRĔCT', directed outward or forward; outstretched. Compare ArRECT.

PǑR'RĔT, see SCALIION.

POS'ǏTǏVE GĒŏT'RŌPǏș, growing toward the centre of the earth-usually called simply 
Geotropism. Compare NEGATIVE GEOTROPIs.r.

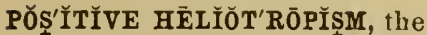
same as Heliotropism. Compare Negative HeliotroPISM.

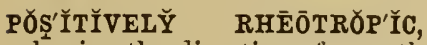
having the direction of growtl in a rheotropic organ coincide with that of the stream in which it is placed, i.e., point down-stream. (Jönsson.) Compare Negatively RheoTROPIC.

POSTĖ'RĨOR, the side of a flower, etc., adjoining the axis or main stem. Compare ANTEIion and Dorsal.

PǑS'TY̌CoǓS, see ExTroRsE.

POUCH, see SILICLE.

POUCH-SHĀPED, like a short bag, as the pod of shepterd's-purse.

PRE Á $^{\prime} \mathrm{COX}$, see Precocious.

PRÄFLŌRA'TION, see EsTIVATION.

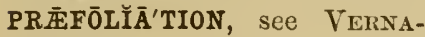
TION.

PR ÁMOORSE', see Preyorse.

PRÁTĚN'SǏs, growing in meatows.

PRËCŌ'ÇIOǓS, appearing or ripening before the proper or usual time: silid of flowers which expand before the leaves, and of plants which flower or fruit much younger than usual, etc.

PRĒFLŌRĀ'TION, sec EsTIVATION.

PREFÖLǏÁTION, see VERNATION.

PRĒMÔRSE', abrupt, and irregularly notched at the end as if bitten off. Compare TrunCATE.

PRICK'LE, a small, sharp, stiff outgrowth from the epidermis. Compare SPINE and THORN.
PRI'MÁR̆ , clief or first formed. For examples see Primary Axis, Primary Cortex, etc.

PRI MARY $X X^{\prime}$ ÍS, the main stem. PRI'MARÝ CÔR'TĚX, the true cortex or fundamental tissue of the bark. Compare SECondary Contex. See PeriBLEM.

PRI'MARÝ LÉAVEȘ, see PIIMORDIAL LEATES.

PRI'MARY MER'ǏSTEM, the growing tissue of a young organ. Compare SecondarY Menistem.

PRI MARY̌ PĚT'Í̄̄LE, the midrib of a compound leaf.

PRI'MARY ROOT, the central or main root, being a direct continuation of the stem; tap-root.

PRI'MÁR̆ STRŬC'TUURE, the early structure of a plant or organ after all its distinctive tissues are formed and before any further growth or modifi. cation takes place.

PRİ'MẢRY̌ TǏS'SŪE, (1) tissue in the coudition when first formed; (2) that which is formed during the first stage or season of growth.

PRI'MẢ WǑ WoD, that contained in the fibrovascular bundles of exogens when first developed, before the formation of the cambinm ring. Compare Secondary Wood.

PRI'MINNE, the onter coat of the ovule, called testil in the seed. Mirbel applied the term primine to the inner coat of the ovule, because first tormed, and some other German writers have used it in the same sense.

PRĬM'ǏTǏVE, original: applied, for example, to the original species from which cultivated plants have been derivel. 
PRÎMôR'DǏAL, original, or first formed.

PRİMÔR'DǏAL CĚLL, a cell without a cell-wall; naked cell.

PRIMMÔR'DǏAL ËPǏDẼR'MǏs, the epidermis as it exists when first formed.

PRIMOOR'DIAL LEAVES, the first leaves to succeed the cotyledons. Applied especially to lower leaves which differ considerably from those on the upper portion of the stem. Compare Protophrld.

PRIMOOR'DĬAL Û́ TRǏCLE, theouter layer of protoplasmadjoining the cell-wall. The term has with some about the same significance as Ectoplasm, though it usually refers more particularly to the immediate surface of the protoplasm (considered as a membrane, though not really oue) rather than to a definite outer layer. The term was first used by Mohl and applied to the layer of protoplasm adjoining the cell-wall in cells which are nearly filled with sap. Upon tlee ipplieation of certain reagents the protoplasm contracts from the rall as a sac, the "primordial utricle."

PRİMôR'DǏŬM ( 1 l. Prīmôr'dỉà), any member or organ in its enrliest condition.

PRISSMAT'ǏC, in the form of a prism-with that, longitudinal faces separated by angles. Applied to stems. Compare TERETE.

PRŌCĂM'BǏŬ, the first formed fibrovascular tissue of au organ before it becomes differentiated into xylem and phloẹm. Compare CAMBIUi.

PRŌCÄRP, see Procarpiuy.

PRŌ'CÄRPE (Bornet \& Thuret), see Procalrpicar.
PRŌCÄR'PǏŬM (pl. Prōcär'pià), in Florider, the female organ (archicarp) before fertilization. It consists of a carpogonium, together with the trichogyne and any other aceessory part. Compare Crstocarp.

PRǑÇ' ÉSS, an厂 projection from a suiface.

PRŌCǓM'BENT, see Prostrate.

PRŌDŪÇED;, prolonged; extended; projected.

PRŌĚM'BRY̌ Ō, (1) the Suspensor, which see; (2) formerly applied to a prothallus, or to the tirst result of the germination of any spore; now restricted to special eases, as the rudimentary first stage of the sporopliore arising from the oöspore in Characex. Compare ProwrCelium, Protonema, and Pizothallus.

\section{PRŌĚMBRY̌ǑN'ǏC BRANCHES,} short branclies sometimes found on the norles of Chura fragilis which resemble the proembryos in structure and serve for reproduction.

PRǑG'ẢMOǓs, preceding fertilization: applied to the cell of the pollen-grain which forms the pollen-tube, in listinction from vegetative cells which are also sometimes found.

PRŌGRĚS'SǏVE MĚTẢMÔR'PHōsǏs, the appearance in place of organs of the usual character of those belonging to a higher or succeeding set, as when petals are replaced by or "converted into" stameus; ascending metamorphosis. Compare Retrogressive MetanoizPHOSIS.

PRŌ'LĀTE, elongated in a polar direction. Compare OBLate.

PRŌLE, a useless term applied both to Form and IRace. 
PRŌLĽP'SǏs, accelerated, anticipated, or hurried development, as in the disease known as "peach-yellows," where axil. lary buds develop into branches the first year.

PRŌLǏFẼRÁ'TION, development in a proliferous manner.

PRŌLIF ẼROǓs, d e velo pi n g buds, branches, flowers, etc., from unusual places. Applied, for example, to a flower from which another flower or a brauch proceeds, to a leaf from which other leaves or brauches arise, to a bulbous plant which abnormally produces bulbs upou the stem above ground, or to any plant which forms young plints in unusual number about its base.

PRŌLǏF' ÍC, fruitful. Sometimes used in the sense of Proliferous.

PRŌLIFǏCĀTION, development in a prolific or proliferous manner; proliferation.

PRŌLİG'ẼROǓs, bearing reproductive bodies of any kind.

PRǑM'ǏNENT, standing out more than usual, or beyond adjoining parts.

PRŌMY Y $\bar{E}^{\prime}$ LIUUM, in Uredineæ and Ustilagineæ, a short and short-lived mycelial growth proceeding from a restingspore and upon which sporidia are borne.

PRŌNĀTE, inclined to grow prostrite; somewhat prone or prostiate.

PRŌNE, lying flat, especially with the face dowuward; ventricumbent. See ProsTRATE and SUPINE.

PRŌNU'CLEŬS, the uucleus of a gamete. Compare GERM-NUCLEUS.

PRŏp, see Fulcrù.
PRŌPĂC'ŨLŬM, see PropagULUM.

PRōPÁg'ŪLA், pl., see PropagULUM.

PRŌPĂG'ŪLE, see Propagulum. PRŌPĂG'ŪLǓM (pl. Prōpăg'ūlà), a term applied to runners, offsets, and stolons-especially to al slender rumner or siolon termiuating in a new plant.

PRŌPĚND'ENT, hanging forward and downward.

PRǑP'ẼR, true or individual. A proper calyx, for example, would be the true calyx of an individual Hower as opposed to the general (alyx (iuvolucre) of a head.

PRŎP'ẼR JŪIÇE, a ternı formerly used for any characteristic fluid of a plant (especially if thickened) in distinction from the ordinary sap, as the "milk" of milk-rreeds. Applied also to the cambium or so-called "descending sap" when in a growing mucilaginous condition.

PRŎPH'ẢSẼȘ, a term proposed by Strasburger for all the phenomena of karyokinesis up to the longitudiual splitting of the threads. Compare Metaphases and Anaphases.

PRŌPHLŌ'ÉM, the first-formed elements of phloèm in a fibrovascular bundle; protophloëm. Applied also to the cylinder of elougnted cells with thickened walls containiug gramulir protoplasm found in the seta of certain mosses surrounding the proxylem.

PRŏSCŏL'LA, an old term for the retinaculum in orchids.

PRǑSĚÑ'€HY̌MA், tissuecoup posed of elongated cells with tapering extremities in the wool and liber. Compare Parencuya. 
PROS'TRATE, lying flat upon the ground, but not rooting; procumbent. Compare CreEPING.

PRŌTǍN'DRÓŬs, having stamens which ripen their pollen before the pistils of the same flower are ready for fertilization. Compare Protogynous.

PRŌ'TĒĬD, see ALBUMINoID.

PRŌ'TẼIN, see ALBUMINOID. Formerly considered a distiuct substance.

PRŌ'TĒǏN CRY̌S'TAL, see CRYSTALLOID.

PRŌ'TĒIN GRĀIN, see ALEURONE.

PRŌ't ĚN, see ProtenchyMa.

PRŌTĚN'€HY̌MÁ, a ternn used by Nägeli for all tissue not of the fibovascular system; proten. Compare EPENchrua. These terms are little used.

PRŌTẼRĂN'DROǓS, see PROTANDROL'S.

PRŌTẼRĂN'THOǓS, baving Hlowers which appear before the leaves, as in the red maple. Sometimes improperly used in the opposite sense. Compare Hrsteranthous and SrnaxTHOUS.

PRōTẼRŏG'Y̌NOǓs, see PROTOG. YNOUS.

PRōThăL'Lİ̇, pl., see ProthaLLIUM.

PRōTHĂL'LǏŬM (pl. Prōthăl'lìa), see Prothalles.

PRŌTHĂL'LŪS, the thalloid structure resulting from the germination of the spore in ferus and other pteridophytes, upon which the antheridia and archegonia are borne; prothatlium. Extended also to the sexual generation of other plants which have an alternation of generations.
PRŌTŌGĚN'ÉSǏs, a term proposed by Rocison for reproduction by buddiug after the manner of protophytes.

PRŌTŌĞ́̌N'ǏC, forıned in the beginning: said of intercellular spaces which are formed at the time the tissues are beginning to differeutiate. Compare Hrsterogenic.

PRōTǑ'G'Y̌NOǓs, having pistils which are ready for fertilization before the pollen of the same flower is ripe. Compare Protandrous.

PRŌ'TŌ-MĚR'ǏSTĚM, see PRIMART MERISTEM.

PRŌTŌN $\bar{E}^{\prime} \mathbf{M A}$ (pl. Prōtōnē'màtà), the proembryo, or confervoid (often brauched) filament first formed from the sporc in mosses, and upon which the conspicuous moss-plant is developed by budding.

PRŌTŌPHLŌ'EM, see ProPULOËM.

PRŌ'TŌPHY̌L, a cotyledon or other first-formed leaf of a plant; protophyllum. Used mainly in raseular cryptogams. Compare Primordial LEA VES.

PRŌTŌPHY̌L'LŬM (pl. Prōtōphy̆l' là), see ProtophyL.

PRŌTŌPHȲTǑL'ŌGY̆, (1) t he study of protophytes; (2) fossil botany.

PRŌ'TŌPLĂ SM, the nitrogenous fluid of variable composition found in living cells. It is the vital substance into which all food is assimilated and from which all parts of the plant are formed.

PRō'TŌPLĂsT (Hanstein), the smallest body of protoplasm capable of individual action, either with or without a cell. 
wall, and either associated in a tissue or independent. It is geverally at least a nucleus, together with the protoplasm associated with it. Essentially a cell.

PRŌ'TŌSPŌRE, any spore which develops a promycelium. Applied by Cook to aeceliospores. An unnecessary term. Compare SPORIDICMY.

PRŌTŌTHĂL'LǓS, see PIothaL. LUS.

PRōTōX'̄'LĔM, see Proxylen.

PRŌTŌZOPH'ǏLOǓS, applied to certain water - plants which have the pollen conveyed by minuteanimalscalled protozoa.

PRŌTRƯD'ǏNG, see ExsERTED.

PRŏX'İMAL, pertaining to the base, or extremity of attachmeut. Compare Distal.

PRŌXY'T'LĔ, the first-formed xylem in a bundle; protoxylem. The term has also been applical to the layer of waterconducting cells destitute of protoplasm around the central strand in the seta of certain mosses. Compare Prophlö̈s.

PRƯ'ÍNĀTE, see Pruixose.

PRƯ' ǏNŌSE, covered with a powdery bloom, like the fruit of most plums: pruinate. Compare Glaucol's, Hoarr, and Canescent,

PRƯ'ÍNOǓs, see Pruinose.

PRƯ'NIFôRM, plum-sliaped.

PRƯ'RIENT, stinging, as the hairs of nettle.

PSEŪDĂX'Ǐs, see SrMPODIUY.

PSEUDO., a prefix derived from the Greek siguifying false or spurious.

PSEŪ'DŌ-BŬLB, see CoRMr. Especially the corm or fleshy base of the stem in many epiphytic orchids.

PSEŪ'DŌ-BŬLBĬL, an outgrowth which sometimes replaces the ordinary sporangia in ferus and bears antheridia and archegonia.

PSEÜ'DŌCÄRP, any fruit which is not derived exclusively from a single ovary withont accessory parts. The fruits of the apple, rose, mulberry, and juuiper are psendocarps.

PSEŪDŌCǑS'TĀTE, said of a leaf in which the veins unite to form an outer vein parallel to the margin, as in Eucalyptus.

PSEŪDŌ-Ġ'NŬS, see FORM-GENUS.

PSEŨDŌG'́Y'RĀTE, sometimes applied to the annulus in ferns when it crowns the sportugium, as in the Schizarcer. Compare Pletrogrrate.

PSEŪDŌMǑNŌCǑTY̌LĚD'ONOǓS, laving two or more consolidated cotyledons. (Obs.)

PSEŪDŌ-PĂR'ẢsĨTE, see ErIPHYTE and SAPROPHYTE.

PSEŪDŌ-PẢRẼ' applied by De Bary to tissue in fungi which is formed by iuterlacing and united hypha.

PSEŪDŌPĚRITHE É ÇǏŬM, a false perithecium.

PSEŪDŌ-PǏN'NĀTE, having leaflets (or rather segments) which are not articulated or petioled at their base; pinnatisect.

PSEŪDŌPŌ'DǏŬM (pl. Pseūdōpō' día), (1) a stipe or stem of $u n$ usual origin, as the leatless upper portion of the stem which supports the capsule in Sphagnum (instead of the true seta which remains unde. veloped; (2) one of the tem- 
porary cliangeable branches of a plasmodium, or one of the retractile appendages of the zoöspores (myxamceß) of Myxomycetes.

PSEŪDŌRĂM'ŪLǓS, a false or spurious branch found in certain Nostochacex, consisting of a vounger filament agglutinated for a portion of its length to in older one.

PSEŪ'DŌSPẼRM, an Achene or Caryopsis.

PSEŨDŌSPẼ R'MǏc, having a single seed so closely invested by the pericarp that the whole appears like a seed, as in grasses and Compositie; psendospermous.

PSEŨDŌSPẼR'MOǓS, see PsEUDo. SPERMIC.

PSEŪDŌSY̌N'CÄRP, see COLLECT. ive Frui's. Compare SrNCARP.

PTẼR̆D'ǏŬM, see SAMARA.

PTĚRŌCÄR'POǓS, wing-fruited.

PTĚRŌCAUU'LOǓS, having a winged stem.

PTE'ROID, wiug-like.

PTẼRÓP'ŌDOǓS, having a winged petiole.

PTĚRŌSPẼR'MOŬS, having the seeds winged.

PTĚRYัGŌ'NOǓS, having winged expansions on the augles of the stem.

PTŌ'MÁINE, any alkaloid formed by the activity of bacteria.

PŪ'BẼRTY̌, the period when a plant first begins to blossom.

PŪBĚR'ŪLENT, minutely pubescent; eovered with short, soft, rather distant hairs. Compare Holosericeus.

PŪBĚS'CENCE, soft and rather short hairs; also extended to hairs of all kinds.
PŪBĚS'ÇENT, coverell with fine, soft, ruther short hairs.

PŪGǏǑN'ǏFÔRM, dagger-sliaped. (Obs.)

PUNL'LEY̌-SHĀPED, sec 'TroculLEAR.

PǓL'LÛLĀTǏNG, bu d d i $u g$; sprouting:-now used only for the budding or sprouting of a cell, a special form of cell-multiplication as seen in yeast, in which a new cell graclually swells out from an older one.

PǓLP, the soft, mole or less juicy portion of a fruit, or other plant-substauce of similar structure.

PǓLVẼRA'CCEOǓS, dusty or pow. dery on the surface. Compare Pulverulent.

PŬLVÉR'ULLENT, (1) powdery or crumbly; (2) pulveraceous.

PǓL'VǏNĀTE, shaped like a cushion or pillow; having a pulvinus.

PǓL'VǏNĀTĚD, having a pulvinus.

PǓLVǏN'ŪLǓS (pl. Pŭlvĭn'ūlī), diminutive of Pulvinus. Applied to various excrescences, and also formerly to the soredia of lichens.

PǓLVI'NǓS (pl. Pǔlvī'nī), a term applied to various cuslionshaped or wart-like protuberances and swellings, as (1) the projection left by the fall of a leaf in many plants; (2) the enlargement at the base of the petiole in certain Leguminosæ which has the power of contraction, producing the "sleep" of leaves; (3) an enlargement formed by the thickening of the bark at the base of certain twigs, as in arbor-vitx; (4) a thickened, usually median, portion of 
the prothallus in ferns bearing the archegonia and antheridia.

PŪ'MǏLŬS, see HUMILIS.

PǓNC'TĀTE, dotted as if by punctures. The dots may be colored or colorless, superficial or interual, in the latter case sometimes caused by minute oil-glands. Compare PerfoRATE.

PǓNC'TIFF̂RM, in the form of eithel a lot or point.

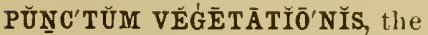
extremity of a stem, or other central point where the cells are in the process of division and growth; growing point; apical cone.

PǓN'GENT, terminating in a hard sharp point. Compare Mucronate.

PÚR'PÓSE, see ADAPTATION.

PǓS'TŪLĀTE, beıring pustules or low, blister-like elevations; pustular; pustulose.

PǓS'TŪLE, a slight elevation like a pimple or little blister. Compare PaPILLA.

PŪT $\bar{A}^{\prime} \mathbf{M E L N}$, the stone of a drupe, or shell of a nut.

PY̌C'NǏDE, see PYCNIDIUM.

PY̌CNÍD'IUŬM (pl. Py̆cníd'̌́à), a receptacle in Ascomycetes containing stylospoles; clinosporangium.

PY̌CNŌÇĚPH'ȦLOǓS, having the flowers densely crowded in the inflorescence.

PY̌CNōCõNĬD'ǏŬ， see STYLLSPORE.

PY̌CNŌG0̄NĬD'ǏŬM, see STYLoSPORE.

PY̌C'NŌSPŌRE, see STrLosPoRE.

PY̌CNǑS'TȦEHOŬS, in compact spikes.
PȲōGENET'ǏC, pus-forming, as certain bacteria.

PY̌RĂM'ĬDAL, either angular and tapering upward, or conical.

PȲRÉ' NÁ (pl, Pyrē'nǣ), a nutlet, or the stone of a small drupe.

P'̄'RENE, see PYRENA.

PỸRE'NŌCÄRP, (1) the perithecimm in Pyrenowycetes; (2) a diupe.

PỸRÉNOIDS, minute rounded colorless gramules, one or more of which are emberlded in the chromatophores of many algæ; amylum bodies; chlorophyll vesicles.

PY̌R'ÍFôRM, see PEAR-SHAPED, PY̌X'ǏDĀTE, resembling a pyxidium or betring pyxidia.

PY̌XĬD'ǏŬM (pl. PyXíd'ía), a capsule which debisces by a circular transverse line; pyxis. Now restricted to secd-capsules, but formerly applied also to certain spore-capsinles, as those of mosses.

PY̌X'ǏS (pl. Pyx'ēș), see PYxidiun.

QUAD-, or QUADRI-, a prefix from the Latin meauing four.

QUẠRĂN'GŪLAR, four-:ıngled.

QUADRǏCRƯ'RAL, having four stems or supports.

QUACRǏDĚN'TĀTE, f o u r toothed.

QUADRĬDÍG'ǏTĀTE, digitate in four divisions.

QUADRǏFA'RǏOǓs, in foul' vertical ranks.

QUAD'RǏFĬD, cleft into four segments half - way to the base or midrib.

QUAD'RIFŌIL, see QUADRIFOLIATE.

QUADRǏFŌ'LǏ $\bar{A} T E$, strictly, fourleaved, hut userl for having four leaflets arising from the 
apex of the petiole; quadrifoliolate; quadriphyllous; quadrifoil.

QUADRIF Ō'LĪōLĀTE, the same as Quadrifoliate, and more precise; i.e., having four leaflets arising from the apex of the petiole.

QUADRǏFÛR'CĀTE, dividing into four branches.

QUẠRÍGĔM'ǏNĀTE, growing in follrs

QUAPRIIJ'ŪGĀTE, haviug four pairs of leaflets; quadrijugous.

QUAPDǏJ'ŪGOǓS, see QUADRIJUGATE.

QUAPRĬLO'BĀTE, having four lobes, as a leaf.

QUẠRĬLǑC'ŪLAR, having four cells in an ovary.

QUAPD'RINATTE, see QUATERNATE.

QUADRÍP'ÁRTITTE, divided to the bise or midrib in four parts: four-parted.

QUAPRĬPH'Y̌LLOǓS, see QTADRIFOLIATE.

QUẠRǏVĂL'VŪLAR, of four valves-satul of pericarps.

QUĀQUA்VẼR'SAL, directed every way.

QUAR'TẼRING, applied by florists to petals which have an external angle or vacaucy between them.

QUẠR'TǏNE, a fourth integument in an ovule (if present) counting from the ontside. It is really a layer or fold of the secundine or of the mucleus.

QUÁTẼR'NÁRY, of four parts. Compare Tetramerous.

QUAंTẼR'NĀTE, gl'owing iu fours.

QUǏLLED (Hort.), applied to double flowers in Compnsita when the corollas of the florets, instead of being ligulate, are more or less tubular in form like a corvet of paper, as is often seen in the dablia.

QUIN-, a prefix from the Latiu meaning tive.

QUI'NA் $\breve{Y}$, in fives or multiples of tive.

QUI'NĀTE, growing together in fives, as five leaflets from the apex of a petiole.

QUǏNCŬN'ÇIĂL, «pplied in rstivation to a whorl of five parts, two of which are exterval, two internal, and oue half external and half internal (the typical method of imbricative restivation when the parts are five). Formerly used also in the sense of five-rankerl. In general use the term is applied to objects arranged in squares witl one at the centre. In horticulture this arrangement is sometimes termed "filse quincumcial," the true quincuncial armugement being the disposition of objeets so that the interveuing spaces are all hexagons.

QUIN'CǓNX, a set of five oljects arrauged in a quiucuucial manner.

QUǏNQUĂN GŪLAR, five-angled. QUǏNQUĒCǑs'TĀTE, five-ribbed. QUǏNQUĒDĔN'TĀTE, fi $\mathrm{V}$ e tootbed.

QUINNQUĒFA'RǏOǓs, five-ranked. QUIN'QUẼID, in five segments reaching about half-way to the base or margin: five-cleft.

QUǏNQUĒFo'LĨ̃TE, having five leaflets; strictly, five-leaved.

QUINNQUEFFŌ'L ĪŌLATE, the same as Quinquefoliate; i.e., having tive leatlets.

QUINNQUĒJU'GĀTE, in five pairs. QUǏNQUĒLO'BĀTE, having five lobes. 
QUǏNQUĒLǑC'ŪLAR, laving five cells in a pericarp.

QUǏN'QUENẼRVED, having two strong veins arising from the midrib on each side near the base; quintuple nerved or veined. Compare QuisqueCOsTate and QUINQUEVEINED.

QUINNQǓ̌P'ÁRTİTE, divicled into five parts nearly to the base.

QUINNQUĒVĂL'VŪLAR, having five valves in a pericarp.

QUINQQUEVEINED, having five strong veins proceecling from the base of a leaf. The same as Quinquenerved, and usually preferable.

QUǏN'TŪPLE, in fives, or multiples of tive.

QUǏN'TŨPLE-NẼRVED, see QUIXQTENERVED.

QUIN'TŪPLE-RÍBBED, sce QCINQLECOSTATE.

RĀÇE, a variety, artificial or nittural, which reproduces itself from seed.

RACQĒME', an indeterminate inflorescence consisting of single-tlowered pedicels arriuged along a common axis. Compare Paxicle and SPlie

RĂÇĒMǏF'ẼROǓS, beariug racemes.

$\mathbf{R A C} \mathbf{C}^{\prime} \mathbf{E} \mathbf{M} 0 \overline{S E}$, disposed in racemes or resembling a raceme.

RĂC' $\mathbf{E} M U \overline{L E}$, a small raceme.

RẢCĚM'ŨLŌSE, producing or disposed in small racemes, or resembling a small raceme.

RÁHIL'LA, the axis of a spikelet in grasses.

$\mathbf{R} \bar{A}^{\prime} \mathbf{E H I S}$, a common peduncle or petiole or elongated receptacle, especialls (1) the midrib of a pinnate frond in ferms; (2) the axis of a spike or raceme: rlachis.
RA'DIAL, pertaiuing to a radius, lay, or border; developed uniformly on all sides around a lougitudinal axis. Compare DORSIVENTRAL.

$\mathbf{R} \bar{A}^{\prime} D \check{I} A L$ BŨN'DLE, the axial fibrovascular system in roots and some lycopods-so called because it consists of alternating radial binds of xylem and phloëm.

RÁǍLNT, spreading from a common centre; radiating; radiate. Also haring a ray or border, as the inflorescence of hydrangea.

$R \bar{A}$ DǏATE, having rays or rayHorets.

RA'DǏATE - VEINED, see PALMATELY VEINED.

RĀ'DǏĀTǏNG, see RADJANTT.

RĂD'ICAL, proceeling from the root, or base of the stem.

RÁD'ǏCANT, rooting - applied only where roots proceed from the stem above ground; radicating.

RÃD'ǏCĀŤ̌D, haring a loot or roots.

RĂD'ǏCĀTǏNG, see RADICANT.

RĂDICÁ'TION, (1) the ar'rnngement or disposition of the - roots in the soil, i.e., whether spreading near the surface or running vertically downward, etc.; (2) the arrangement of the roots and rootlets on their respective axes (rhizotaxis)corresponding to Plyyllotaxis, Caulotaxis, ind Inflorescence: (3) the act of taking root. Compare Ramificatiox.

RĂD'ICELL, a rootlet.

RĂDIČ̉̆ĆC̄LOŬS, growing upon the roots of other plants, as certain parasitic fungi.

RÁDICČIFLO'ROǓs, having the flower-stalk arising from the crown of the root. 
RẢDǏ Ç' ÍFôRM, root-like.

RĂD'ÍCLE, the portion of an embryo below the cotyledons, including the canlicle and nascent root; by some now restricted to the extreme point of the caulicle from which the root develops.

RĂD' ICōSE, having roots unusually large or otherwise remarkable.

RẢDIC'ŪLA (obś.), see RADICLE. RĂD'ÍCŪLE (obs.), see ROOTLET. RẢDǏC ŪLŌSE, bearing roollets or rhizoids, especially if uumerous.

RĀ'DIǓS (pl. Rā'dīî), see RAY.

RÄ'DİX (pl. Răd'icēss), see Root.

RĂG (Hort.), the placenta and] dissepiments (core and membranes) in the orange and other citrus fruits.

RÁ'MAL, see RAMEAL.

$R \bar{A}^{\prime} M \bar{E} A L$, growing on or pertaining to brinches; ramal; rameous.

RĂM'ENT, sing., see RAMENTA.

RẢMĔN'TÁ (sing. Rảměn'tŭm), seale-like hairs of various forms, especially when attached at an end or side like those on the petioles of ferns; raments. A lso applied to other scales. Compare Leproes.

RĂMĚNTĀ'ÇEOŬS, bearing ramenta.

RÄMĚN'TǓM, sing., see $R_{A}$ IIENTA.

RĀ'MẼOǓS, see RAMEAL.

RA'Mİ, pl, see RAMUs.

RAMMÍF'ẼROǓS, see RAMOSE.

RĂMÍFÍCA'TION, (1) the act or process of brancling; (2) a branch, division, or offshoot; (3) the general arrangement of a system of brauches. Applied to either stems or roots. Compare Radication.
RĂMǏFLŌ'ROǓS, producing Howers aloug the larger brauches.

RĂM'ǏFôRM, branch-like.

RÁMİP'ÁROÜS, prod ucing branches.

RÁMŌSE', bearing branches; divided into branches; especially, divided into many branches; rimous.

RÃ'MOÚS, see RAMose.

RĂM'ŪLI, pl, see Rasulus.

RĂM'ŪLŌSE, full of small branches.

RĂM'ŪLOǓS, see RAMUlose.

RÀM'ŨLŬS (pl. Răm'ūlì), a small branch or twig.

RĀ'MÚS (pl. Rā'mī), a branch.

RǍNK, a row, especially a vertieal row of leaves or other organs upon a sten.

$R \bar{A}^{\prime} P H \bar{E}$, the adherent funiculus eonnecting the hilum and chalaza in anatropous or amplitropous seeds. Also inplied to a median line on the frustules of many diatoms, and formerly to the suture between the two halves of the fruit in Umbelliferæ; rhaphe.

RĂPH'ǏDẼS, needle-shaped crystals; rhaphicles. Sometimes improperly applieel to plantcrystals of other forms. They are usually composed of oxalite of lime, and occur in large unmbers in certinin plants.

RAPHÍD'ǏAN, pertaining to raphicles. A raphidiun cell is a cell containiug raphides.

RÂRE, sparse or few. Seldom used in this sense.

RÂRE'-RİPE, see RATH-RIPE.

RĂTH'-RIPE (rare), ripening or maturing early in the season; rare-ripe.

RÁTOON', a sprout from the root or base of a plant which las been cut off (applied mainly 
to sugar - cane). Compare Sucker and Pliant-cane.

RẠUMPÄ'SITT, see AULOPHTTE.

$\mathbf{R A} \mathbf{A}$, a brancl of an umbel or other somewhat radiating inflorescence; the ligulate corolla of an outer floret in a head of Composita; the margin of any circular surface, as distinguished from the central portion or disk.

RĀY - FLō'RĚT, see Ligulate FLORET.

RĀY-FLOW'ẼR, one of the marginal florets of a lsead in Compositæ; ray-floret: ligulate tloret. Also, a marginal Hower in other flat-toppeal Howerclusters, especially when differeut from those of the centre or disk, as in hydlangea.

REC ĚEP'TÁCLE, the place upon or within which anythiug is borne, as the summit of a Hower-stalk upon which the floral organs are arranged, or upon which the flowers of a head we situated.

RĚÇĚPTĂC'ÛLAR, pertainiug to or growing upon a receptacle.

RĔÇĚPTĂC'ŬLAR TŪBE, s e e Calyx-tube. Compare HyPANTHIUM.

RẼ ÇĚP'TǏVE SPǑT, the place in an oösphere at which the male gamete enters; i.e., at which fertilization takes place.

RĒÇĚSS', see SIINUS.

R ĚC'LINĀTE, bent over so that the apex is lower than the base, or until it rests on some support; reclined; reclining. Said of stems or branches when ereet or ascending at the base, then turniug toward the ground; of leaves in the bud when the blade is bent down upon the petiole, etc. When applied to a viue grow- ing upon the ground it las about the same meaning as Recumbent and Decumbeut.

RẼCLINED', see RECLINATE.

RĒCLIN'ǏNG, see RECLINATE.

RĒCRỤDĚS'ÇENÇE (obs.), see REJUVENESCENCE.

RĚC'TǏNẼRVED, parallel-veined. RĔCTǏPẼTĂL'ǏTY̌, the tendency of growing organs to grow in a straight line. (Vochting.)

RĚCTİsÉ'RǏAL, in straight rows. RĒCÛR'VĀTE, see RECURVED.

RĒCURVED', curved outwarl or backwarl to a moderate extent, between forty-tive and ninety degrees. Compare Reflexed.

REDU'PLICCĀTE, applied to par'ts of a flower in astivition when they are valvate and have the margins retlexed.

RẼDUPLICA $\bar{A}^{\prime}$ TION, an inerease in the number of parts in a flower according to the plan upon which it is founded, i.e., by the addition of similar whorls; regular multiplication.

RĒFLĔCT'ĚD, see REFLEXED.

RĒFLĚXED', turned backward or outward more than Recurved, or to about the sime extent but abruptly; reflected. Compare Reconved and DEFLECTED.

RĒFLŌRĚS'ÇENÇE, blossoming allew.

RĒERĂCT'ĚD, bent abruptly outward or bickward, at an angle of more than forty-five rlegrees. Compare Deflexed and ReCURVED.

RËĞENẼRĀTION, see REJUVENESCENCE.

$R \bar{E}^{\prime}$ GION, an extent of country enclosing particular species, which are distributed through it in the stations adapter to their growth, and which, owiug 
to natural conditious, are not generally found elsewhere, as the Arctic and Mediterranean regions.

Ř̌G'MÁ, a fruit with elastically dehisciug cocci, as in Euphorbia.

RĔG'MẢCÄRP, see REGMA.

RËGRĽS'SION, see RETROGRESsive Metamolrphosis.

RÉG'ŪLAR, said of a flower which has all the parts of each whorl alike in size and form; actinomorphous.

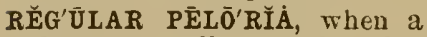
flower, usually regular, becomes irregular by the nondevelopment of some part. Compare Peloria, Irregular Peloria, and Epanody.

RẼUUVENĚS'ÇENÇE, (1) the formation of a single new cell from the entire contents of a cell already formed (" renewal of cells"); especially, where the new cell escapes from the old cell-wall and develops a new plant, as in Edogonium and some other algæ; (2) the renewal of growth and vigor as the result of conjugution or other form of fertilization (rare); (3) any renewed growth, or manifestation of increased vigor, as the annual growth of new canes in the ralspberry or the formation of vigorous shoots from near the ground in otler shrubs; renewal; rcgeneration.

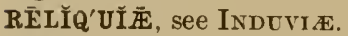

RĒMŌTE', separated by greater intervals than usual.

RENEW'AL OF Ç̌LLS, see REJUVENESCENCE.

REN'ǏFÔRM, kidney - shaped: heart-shaped, but broader than long and very deeply lobed at the base.
RËPAND', baving a slightly undulating or sinuous margin. Compare Sinuate.

RE'PENT, see CREEPING.

RĚP'LICĀTE, folded backward at the sictes or end. Compare Revolute.

RE'PLǓM, a frame-like placenta in Cruciferte aud certain other plauts across which the septum stretches, and from which the two valves fall away in dehiscence.

RẼPRŌDǓC'TǏVE ÔR'GANS, in flowering plants, the stamens and pistils.

RĔP'TANT, see C'REEPING.

RĒŜẼVE MÁTE' RĬAL, assimilated plant-food which is capable of again becoming food to serve in the growth of the plant, as starch.

RĔS̆IN-CĔLL, a cell which has the office of secreting resin.

RĚS̆IN-DǓCT, sce RESIN-PASSAGE.

RĔȘ'IN-GLĂND, a cell or group of cells which secrete resin.

RĔŠǏǏF'ẼROǓS, p rod u c in g resin.

RĔS'ĨN-PĂS'SĀǴE, an intercellular space or contiuuous gland in or into whieh resin is secreted; resin-duct; resin-tube.

RĔȘİN-TŪBE, see RESIN-PAsSAGE.

RĔSPǏRA'TION, in a broad sense, includes all trinsfers of gases and vapors between the plant and the air. As usually employed it refers to the absorp)tiou of carbon dioxide from the air, and its deeomposition in the plant, with the assimilation of the carbon and the liberation of the oxygen. In a striet sense it applies to the same process as respiration in animals, though existing in 
plants to a feebler degree, namely, the reception of oxygen, the oxidation of oxidizable matter, and the release of the products of oxidation. See Transpiration.

RẼSPI'RẢTōRY̌ CĂV'ǏTY̌, see STOMATIC CHAMBER.

RĒSPI'RẢTŌRY̆ CHĀM'BĔR, see Stomatic Chambler.

RĔS'TANT, see PERsistent.

RĚST'ǏNG ÇĚLL, see RESTINGSPORE。

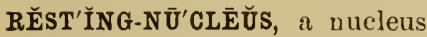
when not in the act of karyokinesis. The nuclear filment then exists in the form of granules, or as a vetwork, often with one or more nucleoli.

REST'ǏNG PE'RĪoD, the period during which a plant, seed, or spore remains dormant. Applied mainly to the dormant period of it resting-spore, then also called by some "involution-period."

R ĚST'ǏNG-SPŌRĂN'ǴĬŬM, a term applied by Pringsheim to certain doruant gonidia of Saproleguia and related fuugi which eventually produce swarmspores.

R ĚST'ǏNG-SPŌRE, a spore fulnished with thick walls and able to retain its vitality for a considerable time, and generally requiring the lapse of time, often over winter, before it will germinate; winter-spore; hypnospore; statospore.

RĚST'ǏNG-STÁGE, the stage or condition of a plant, bulb. seed, or spore duriug its dormant or resting period.

RẼSÜ'PǏNĀTE, upside-down; inverted; retroverted; reversed. Compare SupINE.

RĒTIC'ŨLĀTE, in the form of network, as the veins in the leaves of most plants.

RĒTǏC'ŨLĀTĚD, see RETICULATE.

RĒTǏC'ŪLĀTĚD VĚS'SĚL, one having thickenings in the form of network.

RĒTÍCŪLA'TION, any network; reticulum.

RĒTIC'ŨLŬM, a fibrous membrane at the base of the petioles in palms (mattulla); the network which pervades the substance of the cell and nucleus enclosing the softer portions of the protoplasm; any system of filaments or fibres in the form of network.

RĔT'ǏFôRM, see RETICULATE.

RĔTǏNĂC'ŪLŬM (pl. Rĕtǐnăc'ūlá),

(1) the viscid glandular disk derived from the rostellum at the base of the caudicle of a pollinium in orchids by which it is attached to a visiting insect (cement-disk of Müller); (2) one of the arms connecting the pollinia of milk-weeds with the corpusculum; (3) the persistent indurited look-like funiculus of the seeds in most Acanthacex.

RĔT'ǏNẼRVED, see RETICULATEVEINED.

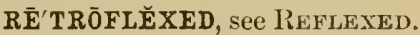

RE'TRÖFRĂCTĚD, see RE FRACTED.

RĒTRŌGRÉS'SION, see RETROGRESSIVE METAMORPHOSIS.

RĒTRŌGRĚS'SǏVE MĚTÁMÔR'PHŌSİS, the occurrence in the place of orgins of the usual character of those belonging to a lutrer condition or position, as when pistils become converted into stamens, petals, or leaves; descending metimorphosis; retrogression; re- 
gression. Compare ProgresSIVE MIETAMORPHosis.

RETRÔRSE', turned backward in auy manner.

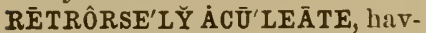
ing prickles directed backward or downward, as on the stem of Galium asprellum.

RE'TRŌVẼRTĚD, see REsUPINATE.

RĒTUSE', slightly notched at a rounded apex. Com pare EMARGINATE.

RĒVẼRSED', upside-down; resupinate; directed backward toward the base; extending in an oppositc to the usual direction.

RẼ Ṽ̃R'SION, appearunce in an earlier, lower, or simpler form than usuil. See RetrogressIVE METAMORPHosis and A TAVISI.

RĚV'ŌLUTTE, rolled outward, backward, or downward. Compare Ixrolcte aud CukCINATE.

RĒVŏLV'ǏNG NŪTA'TION, see Cuncemptation.

RHĂB DOID, an acicular or spiudle-shaped protoplasmic body found in the stalk-cells of the tentacles of Drosera and in the mesophyll cells of Dionrea; plastoid. It tends to become spherical when the part is stimulatel, but its full signifcance is unknown.

RHA $\bar{A}^{\prime} € H I \check{S}$, see RACHIS.

RHA $\bar{A}^{\prime} \mathbf{P H} \overline{\mathbf{E}}$, see RAPHE.

RHĂPH'ǏDẼS, see RAPHIDES.

RHĒŏT'RŌPISM, having the direction of growth determined (not mechanically) by a current of water. (Jönsson.) See PosItively and Negatively Rheotropic. Compare HeliotROPISII.

RHĪZAMÔR'PHōD, see RHIZOMORPHOUS.
RHĪZĂN'THOǓS, parasitic upon the roots of another plant, and producing Howers with little or no green foliage of its own, as RatHesia and Monotropa. A ter'm of little importance, seldom used. Compare RADICIFLOROUS.

RHǏZI'N $\dot{A}$ (pl. Rhǐzí'næ), see RHIZOID.

RHI' ZINNE, see RHIZoID.

RHĪZŌCÄR'POǓS, having a perennial root and herbaceous stem; rlxizocarpic. (Rare.)

RHǏZ ŌĞKN, (1) a plant which is parasitic upon the roots of another; (2) any part or organ which emits roots or rhizoids.

RHĪZŌGĒẼLT'ǏC, root-producing, as rhizogenetic tissue; rhizogenic.

RHIZŌGĚN'ǏC, see RHIZogENETIC.

RHI'ZOID, adj., see RHIzomorPHOCS.

RHI'ZOID, n., a root-like organ in many cryptogams; rhiziua; rhizine. Compare Root.

RHĪZō'MA (pl. Rhīzō'mátá), see RHIZOME.

RHĪZŌMĂT' ǏC, laving the appearauce or character of a rhizome.

RHİZ̄ME', a subterranean stem, especially if uniformly thickened for the storage of starch, etc.; rhizoma; root - stock. Compare STOLON and TrBER.

RHİ'ZŌMôRPHS, root-like organs in Agarics and some other fungi composed of many united hyphal strands.

RHİZ̄MôR'PHOǓs, root-like; rhizomorplioid; rhizoid.

RHI'ZŌPHŌRE, a structure in certain species of Selaginella which resembles a root and from which true roots are cleveloped. 
RHĪZŌPHY̌L'LOǓs, emitting roots from the leaves. (Ranc.)

RHİZ̄TĂX'ǏS, the position or orter of arrangenent of the roots upon a plant; radicution. Compare Phylotaxis aud Caulótaxis.

RHİ'ZŌTĂXY, see RIIIZOTAXIs.

RHōDŏL'ōGY̌, the part of botauy which treats of roses.

RHO'DŌPHY̌L, the compound pigment which is the coloring matter of red algx, the Floriclex.

RHŌDŌSPẼR' $M$ ǏN, crystalloids of proteid found in the Floridere containing the rhodophyl or red coloriug matter.

RǏB, a large prominent vein.

RÍBBED, (1) having more than one prominent longitudiual vein; (2) applied to an upple or other fruit with large longitudinal ridges.

RIC'TǓS, an old term for the throat of a persouate flower.

RÍGĚS'ÇĚNT, approaching a rigid or stiff consisteuce. (M. C. Cooke.)

RIGHT, see remarks under DExTROLSE and LEFT.

RI'MA (pl. $\left.\mathbf{R} \bar{I}^{\prime} \mathbf{m} \bar{x}\right)$, a chink or cleft.

RĪMŌSE', abounding with chinks, clefts, or cracks, as the bark of many trees and the thallus of certain lichens; rimous,

RĪM OǓS, see RıMosE.

RĬM'ŪLōsE, diminutive of Rimose.

RĨND, see CoRTEx.

RĨNG, see ANNULUS.

RǏNGED, see AxNOLATED.

RIN'GENT, bilabiate, with the lips widely separated and the throat open, as in Lamium. Compare Personate.
RǏPA'RǏAN, see RIPARIOT's.

RǏPA'RĬOǓS, growing aloug rivers or other water-courses; riparian.

RǏvōSE', having sinuate cluannels. Compare SulCaTE.

RǏV'ŪLōsE, having suall siuuate channels. Compare Stuate.

RǑD - FRŬCTǏĔCA'TION, unbranched govidiophores in Basidiomycetes.

RŌGUE (Hort.), an iuferior sport or variation, i.e., a plant which deviates in an undesirable manner from the type of the species or variety.

$\mathbf{R} \overline{0} \mathrm{~T}$, the lescending axis;- cliffering in character from the stem chiefly in being destitute of leaves. Compare RHuzold and RHizone. Sichs extends the term Root to the root. like organs (rhizoids) of cellular plauts.

R00T-CÁP, a protective covering 10 the growing extremity of roots; calyptra; pileorhiza.

RŌT-HÂIRS, slender hairs upon the younger roots, which serve to absorb food from the soil.

R $\overline{00}$ T-LEAF, a leaf springing from the base of the stem.

ROOTT-PRĚS'SŪRE, see SAPPRESSURE.

ROOT'LET, a small root; rootfibre.

ROOT-SHËATH, SEe COLEOIHIZA. R00T'STǑCK, see RHIZoME.

RŌ'RIDUUS, covered with transparent elevations resembling drops of (lew, (Obs.)

RŌS̄Ā'ÇEOǓS, rose-like, or belonging to the family Rosacex.

RŌŠĚL'LA் (obs.), see Rosette.

RŌŠETE', a cluster of leaves or other organs arranged somewhat like the petals of a 
double rose, as the leaves of the dandelion or those upon the short spurs of the lareh.

RŎS'TĚL, see RosteluUM.

RǑS'TĔLLĀTE, diminntive of Rostrate, having a simall beak.

RŎSTĚL'LIFôRM, beak-shaped, especially when the process is small; rostriform.

RǑSTĚL'LŬM (pl. Rŏstěl'lä), a little beak; especially, the process upon the column in orchills containing the lisk (retinaculum) of the pollinia. It is one of the three united styles which has become modified for this purpose.

RǑS'TRĀTE, see BEAKED.

RŎ'TRǏFÔRM, beak-shaped.

RŎS'TRŬM, see BEAK.

Rō'SŪLA (obs.), see RosETTE.

Rō'SUULAR (obs.), see RosULATE.

Ro' $\bar{O}^{\prime}$ SULĀTE, arranged or shaped like a losette; having the leaves in little tufts like the petals of a double rose, as those of the dandelion.

RŌ'TĀTE, wheel-shaped. Iu flowers, applied to a gamopetalous corolla with a very short tube and nearly flat spreading border.

RÕ'TĀTE-PLĀNE, gamopetalous, with a flat border and no tube.

RŌTÁ'TION, a flowing movement of the protoplasuic cell-tiuid; cyclosis; streaming. In some active or growing cells the movement is readily visible as distiuct currents having a rotary or back-and-forth direction. The term Cyclosis is now Tell established, and is perbaps preferable to Rotation as a general term, the latter word being applied especially to circulation next the cell-wall, to a rotation of the whole mass within the cell, or to a peculiar spiral movement of the cell-fluid in certain plants, as in Chara.

Rō'TǏFôRM (obs.), see RotATE.

RŌTǓND', rounded; somewbat orbicular.

ROǓGH, see Scabrous.

ROǓGH LEAVES, a gardener's term for the true leaves which succeed the cotyledous.

RƯBĔS'ÇENT, reddish or rosy; rubicind.

RU్ల'BĬCUัND, see RUBESCENT.

RỤBÍG'INNŌSE, of the color of iron. rust; brownish red; rubiginous; rufous; rusty; ferruginous.

RỤBÍG'ǏNOǓS, see RUBIGINosE.

RỤ'DẼRAL, growing in rubbish or waste places.

RƯ' DǏMENT, an imperfectly developed, vestigal, or aborted part.

RỤDǏMĚN'TAL, see RUDIMENTARY.

RỤDĬM̌̌N'TÁRY̌, imperfectly developed, or in an early stage of levelopment; rudimental.

RỤFĔS'ÇENT, somewhat l'ufous.

RŬF'FLED, sometimes applied to a margiu when very strongly waved.

RU్N'FOǓs, see RuBrgrNosE.

RƯ'GA, a wrinkle.

RŬG'G ĔD (obs.), see ScABRoUs.

RƯGŌSE; wrinkled, as the leaves of sage. Compare Buly.ATE and CRisp.

RƯ'GŪLŌSE, slightly rugrose.

RỰ'MǏNĀTĔD, said of the albumen or cotyledous of a seed which has holes or channels into which the inner seed-coat penetrates, as in the papaw aud nutmeg. 
RŬN'ÇINĀTE, having large sharp teeth or lobes projecting backward, as the leaves of daudelion.

RŬN'NẼR, a stolon which loots and forms new plants at intervals, as the strawberry; the prostrate stem of a vine, as in melous.

RǓN'NǏNG, prostrate upon or beneatl the surface, but not rooting. Often nsed improperly in the sense of Creeping, which see.

RỤPÉS'TRĬNE, growing u p o n rocks or in rocky places; lapidose; saxatile; saxicole; sixicoline; saxicolons; rupicoline; rupicolous. The distinctious between these terms are mainly slight and inconstant. Lapidose may, however, be defined ins growing upon land abounding in loose stoues or coarse grivel (compare Glareose). while the other terms msually refer to fixed or massive rock. There is a tendency, also, to restrict the terms Rupicolous and Saxicolous to growth directly upon the rocks, as with many lichens, mosses, and some ferns.

RỤPIC ŌLOŨS, see RUPESTRINE.

RŬP'TǏLE, dehiscing in an irregular or acciclental manner.

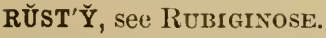

SĂB'ŪLǏNE, see ARENACEOUS.

SĂB'ŨLŌSE, SEe ARENACEOUS.

sĂc, a leep or closed receptacle. Also written Sack.

SAC'CĀTE, in the form of a bag or ponch; sacciform.

SAC OF THE ĂM'NǏǑs (obs.), see EMBRYO-SAC.

SĂC OF THE EM BRY̌ō, see EMBIRYO-SAC.

SACK, see SAC.
SĂG'ǏTTĀTE, arrow-shaped. Differs from Corlate in having the lobes as well as apex acute.

SÁ'LIENT, projecting outward.

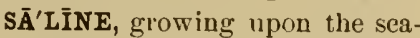
shore or other places impregnated with salt; salsuginous.

SĂLSŪ'ǴY̌NOǓS, see SALINE.

SĂL'VẼR-FôRM, see HYPocRATERIFORM.

SAL'VẼR - SHARED, see HYPoCRATERIFORM.

SÁM $\overline{\mathbf{A}}^{\prime} \mathbf{R} \dot{A}$, a winged frnit, like that of the ash, elm, or maple; pteridium; key.

SAM'ÁR̄D, winged like a samara.

SĂP, in general, any vegetable fluid, especially limpicl fluid, such as abounds in many trees in spring. See CELL-SAP.

SĂP-CĂ

SAY'ÍD, having a pleasint taste.

SÁP'LING, a tall seedling tree having a stem from two to six inches in diameter.

SAP - PRĚS'SÜRE, the force exerted by the soil-fluid in entering the plant, and by the sap in passing upward within it; root-pressure. See Osmose.

SÁPRס̄G'ẼNOǓS, causing putrefaction.

SAP'RŌPHȲTE, a plant which lives upou dend animal or vegetable matter; hum usplant. Compare Parasite.

SAPRŌPHY̌T'ǏC, living upon dead organic matter. Compare Parasitic.

SÃP-VĔS'SĔL, see VESSEL.

SĂP' WŌOD, see AlBURNum.

SÄRCǑB'ȦSĬS, see CAIRCElUULE.

SÄR'CŌCÄRP, the succulent fleshy portion of a fruit, especially of a drupe. Used by 
MI. T. Masters synonymously with Berry.

SÄR'CōDẼRM, a fleshy layer in certain seed-coats; sarco. del'na.

SÄR'M $\mathbf{E} \mathbf{N} T$, a long sleuder runner, stolon, or twig; saruentum; flagellum.

SÄRMĔNTÄ'CEOŬS, see SARMENTOSE.

SÄRMĚNTǏF' ẼROǓs, b e a r in $g$ sarments.

SÄRMENTŌSE', bearing or resembliug sarments; sarmentaceous; sarmentous.

SÄRMĚN'TOǓS, see SARMENTUSE.

SÄRMĚN'TŬM (pl. Särměn'tà), SEe SARMENT.

SẠU'SĀGE-SHĀPED, see ALLANTOID.

SAW-TŌ0THED, see SERRATE.

SĂX ÁTǏLE, see RUPESTRINE.

SAX'ǏCŌLE, see RUPESTTINE.

SĂXIC'ŌLINE, see RUPESTRINE.

SĂXǏC'ōLOǓS, growing u p 0 u rocks, as luany mosses and lichens; rupieolous. Compare RuPESTIRNe.

SCA'BRĀTE, see SCABRoUs.

SCA'BRǏD, slightly scabrous.

SCA'BRĬDOǓs, somewhat scabrid or seabrons.

SCA்BRĬD'ŪLOǓS, slightly scabrid or scabrous; scabridous.

SCÄ'BROǓS, rough with short stiff bairs or points; scabrate: asperate.

SCÁLĂR'ÍFÔRM, having transverse bars like a ladder: applied mainly to thickenings of this form characteristic of scalarifor'm ressels.

SCÁLĂR'ǏFÔRM DŬCT, see SCALARIFOHM VESSET.

SCA்LĂR'ǏFÔRM MÄRK'ǏNG, an elongated pit of a scalariform vessel.

SCA்LĂR'ǏFÔRM VĔS'SĚL, a ves. sel marked with elongated transverse bordered pits, as in mauy ferus.

SCĀLE, any thin, scale-like appendage, usually al degenerated and metamorphosed leaf, as those of bucts and buds. See RaueNTun and LEPIDE.

SCÁL'LION, a small or imperfect onion, particularly the shallot, Allium Asculonicum. Com. pare Sculliox.

SCAL'LOPED, see CRENATE.

SCA $\bar{A} L^{\prime} \breve{Y}$, cousisting of scales: furuished or covered with scules; scale-like in texture.

SCĀL'Y̌ BŬLB, one with uarrow and somewhit separate scales, as in the lily. Compare TuxiCATED Bulb.

SCĂN'DENT, see CLIMIBING.

SCĀPE, a peduncle rising from the ground, as in blood-root, Sunguinariu Cunadensis; i.e., a stalk from the root or collar which bears one or more flowers but no foliage-leuves.

SCĂPH OID, see NATICULAR.

SCĀPǏFLŌ'ROǓS, having the Howers on scapes.

SCA'PǏFÔRM, scape-like; scapoid. SCĀPİG'ĚROǓs, bearing seapes.

SCA POID, see SCAPIFORM.

SCA'PǓS, see SCAPE.

SCÄR, the mark left by the natural separation of a leaf or other organ; cicatrix. See LEAFSCA IR and HiLuM.

SCĀ'RĪŌSE, see SCARIOUs.

SCÄ'RİOŬS, dry and membranous; scariose.

SCÃT'TĚRED, either sparse, or without apparent regularity 
of arraugement. See AlterNATE.

sEHĬZ'0̄CÄRP, ¿ fruit of which the carpels separate when mature and retain the seeds in cocci or mericarps.

S૯HǏZōǴENĚT'IC, see SCHIZOGENIC.

s૯HǏZŌĞ̌N'Ǐc, formed by the separation of parts, as some intercellular spaces: schizogrenetic; schizogenous. Compare Lxsigenic.

SEHĨZŎG'ẼNOǓs, see ScHIZOGENIC.

SÇIM ẼTAR-SHÄPED, see ACINACIFORMI.

SÇI'ON, formerly used for any shoot or twig: now applied only to one iatended for grafting. Improperly written Cion. A scion is considered by most nurserymen to be a part of a twig or shoot long enough to make one graft, usually four to six inches.

SCYI'UROID, in the shape of a squirrel's tail.

SCLERŘEN'EHY̌MÁ, lignified tissue of any kind, especially such as composes the shell of a nut. It is not usually applied to ordinary moody tissue, but is used by many botanists for thick-walled fibres of the bast and hypoderma.

SCLĚR'ŌGLN, sEe LIGNINE.

SCLE'ROID, woody or bony in texture.

SCLËRō'SǏs, see LIGNIFICATION. SCLE'RŌTE, see SCLEROTIUM.

SCLĒRǒT'İc, resembling or consisting of selerenchyma.

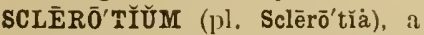
consolidated and lardened mass of hyphe in a resting condition, as in Claviceps (ergot) and some other Ascomy- cetes. Also a temporary condition assumed by the plasmodium of Myxomycetes, chietly due to aryness, in which it appears in dry, compact, waxlike, gritty nodules.

SCLĒRŌ'OID, consisting of or resembling a sclerotium.

SCŌBǏC'ŪLAR, see SCOBIFORY.

SCǑB'ǏFôRM, resembling sawdust; scobicular.

scōBI'NA, an old term for the zigzag rachis of certain grisses.

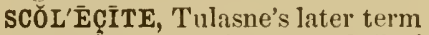
for the "vermiform body" of Woronin. It is the asengonium or archicarp in certain Ascomycetes, as Ascobolus pulcherimus.

SCÔR'PĪ̄ID, commonly used in the sense of Helicoid, but properly restricted now to alternately progressive or zigzag development. See Scor PIOID Crue and SconpioId DICHOTOMY.

SCÔR'PĪOID ÇȲME, one in which the successive flowers are situated on alternate sides of the psendaxis: cicinal cyme; cicinus or cincinnus. The term Scorpioid Cyme was given by A. P. de Candolle to a unilateral cyme, the undeveloped portion of which is usually rolled up like the tail of a scorpion, as in Boriginacea, and this is the meaning still attached to the term by most botanists of England. Compare Helicoid Crue.

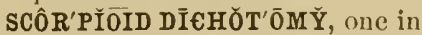
which alteruate branches develop in the successive bifurcations; cicinal dichotomy. Compare Helicoid DichotoMrY.

SCRŌBǏC'ŨLĀTE, pitted. 
SCRŌ'TǏFôRM, see PoUCH SIIAPED.

SCUัL'LION, a term applied by gardeners in America to onions which fail to "bottom" properly, but remaiu soft and become thick-necked. Probably derived from Scallion, which see.

SCǓLP'TŪRED, a horticultural term applied to the seeds of certain gourds, etc., which have peculiar markings.

SCURF, small bran-like epidermal scales.

SCŨ'TÄTE, shield-shaped, especially like a round shield; scutiform; clypeate. Compare Peltate.

SCŨ'TĚL, see SCUTELLUA.

SCŪTELL'L正FÔRM, see SCUTELLIFORM.

SCU'TĚLLĀTE, diminutive of Scutate; somewhat scutate, like a platter; especially, covered with small plate- or shieldlike surfaces; scutellated. See SCUTELLIFORM.

SCŪ'TĚLLĀTĚD, see SCUTELLATE.

SCŪTEL'LIFÔRM, shaped like a sancer or small platter; scutellate; scutellæform. Compare Patelliform.

SCŪTĚL'LŬM (pl. Scūtěl'là), (1) a sessile apothecium or "shield" in lichens; $(2)$ in Gramineæ a usually shield-like expansion of the hypocotyl which acts as an organ of suction through which the embryo absorbs nutriment from the endosperm. It is regarded as the cotyledon. It appears exteriorly as a large flat space upon the surface of the seed surrounding the embryo (plumule and radicle) to which it is attached. It forms the chief part of what is known as the "chit" in a kernel of corn. Compare Scutum.

SCU'TIYFÔRM, see SCUTATE.

SCÜ'TǏFÔRM LĒAF, the firstformed leaf (protophyl) in Salvinia, differing in form from the succeeding leaves.

SCŪ'TŬM, a large circular disklike part or organ, as the dilated stigma (stylostegium) of Stapelia; shield. Compare Scutelluar.

SÇY̌M'ǏTAR-SHĀPED, see ACINACrFORM.

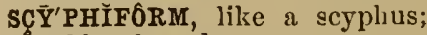
goblet-shaped.

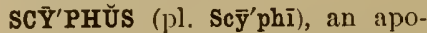
thecium in lichens elevated on a podetium. Compare ScuTELLUM.

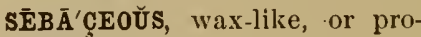
ducing wax.

SĒBǏF'ẼROǓS, producing wax.

SĚC'ONDARY̌, opposed to Primary; often includes Tertiary, etc.

SĚC'ÓNDĀRY̌ BŬDS, see ACCESSORY BUDS.

SĚC'ÓNDĀRY̌ CÔR'TĚX, a collective term for the successive fo:mations of liber or bast within the cortical sheath and primary cortex. It is not applied to secondary cork formations.

SĚC'ONDÄRY̌ FŬN'GŬS, a saprophytic or parasitic fungus which attacks a plant after it has been killed or injured by another fuugus. Compare SCPERPARASITE.

SĚC'ÓNDĀRY̌ HȲ'BRĬD, see DERIVATIVE HYBRID.

SĚC'ÓNDĀRY Y MĚD'ǓLLĀRY̆ RAYS, those intermediate between the rays first formed, and which do not extend to the pith. 
SĚC'ONDĀRY̌ MĔR'İSTĚM, meristem in an organ or part after its first development is completed and by means of which further growth is effected, as cambinm. Compare Primary MERISTEM.

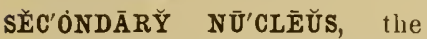
"nucleus of the embryo-sac," resulting from the uuion of the $t$ wo polar nuclei.

SĔC'ONDĀRY̌ PĒDƯN'CLE, the stillk of a branch of an inflorescence bearing more than one flower; pirtial peduucle. Compare Pedicel.

SĚC'ONDĂRY PËT'ǏOLLE, the stalk of a leatlet; partial petiole petiolule.

SĚC'ONDĀRY̌ R $\overline{00} T$, a lateral root, especially one growing from the stem. Compare Prinary Roo' and AËRIAL Root.

SĚC'ONDĀRY SPŌRE, a spore borne on a promycelium (sporidium), or one derived immediately from another spore.

SĚC'ONDĀRY STRǓC'TŪRE, the structure or condition of a plant or organ after its first year, or after it has grown beyond its first formed state. Compare Primary StrucTURE.

SĔCONDĂY̌ WOOD, the portion of the wood or xylem which is formed after the primary xylem, or after the formation of the cambium ring. Compare Primary Wood.

SĔC'ONDĪNE (obs.), see SECUNDINE.

SĚC'TǏLE, divided into separable parts.

SE'CǓND, either unilateral (oneranked) or homomalous (onesided), i.e., having lateral organs upon one side only, or all turued to one side.
SEC'ÚNDINE, the secondary or inuer coat of an ovule, called tegmen in the seed. By some authors this inner coat, since it is first formed, is called the P'rimine and the outer coat the Secundine.

SEED, a fertilized ovule: a structure enclosing when mature a rudimentary plant (the embryo) which is protected while in a dormant condition, and fur. nished with nutriment, either in its cotyledons or around them, with which to begin the process of growth.

SEED'ĀGE, a term proposed by L. H. Bailey for the process, state, or condition of being propagated by seed.

SEED-BŬD, an old term used both for ovule and ovary.

SEEED.CŌAT, the covering of a seed. See Tegmen and Testa.

SEED-LEAF, see COTYLEDUN.

SEED'LING, (1) a plant produced from seed, in distinction from one produced in any other manner, either vaturally or artificially; (2) a young plaut produced from seed, in distiuction from one of considerable age or size.

SEED-LŌBE, see COTYLEDON.

SEED-SPŌRT, a sport which originated from seed; seminal sport. Compare Bud-sPol' $\mathrm{T}$.

SEED-VĀRI I'A'TION, a variation derived from seed instead of buds. Compare Bud-variATION.

SEED - VẢRI'ETY̌, any variety which originated from seed, either suddenly (seed - variation or seed-sport) or gradıally in the ordinary way, and is propagated in any minner. Compare Bud-varie'tr.

SEED-VĚS'SĚL, see PERICARP. 
SĚG'MENT, a natural division or part; as one of the parts of a compound or deeply divided leaf, an internode, the cell of a pericarp, any joint or regular part whether separable or not.

SEKGMĚNTĀTION, the act or process of dividling into segments.

SĚG'RĒGĀTĚD, separated.

SEI'RŌSPŌRE, a lind of gonidium produced in movilliform rows in certain red algæ.

SĚLF, a florist's term for a flowel or plaut which is wholly of one color.

SĚLF-CÓL'ORED, applied to fruits and flowers which are of one color; unicolor. Compare Colored.

SĔLF - FẼRTILLǏZA'TION, s e e Close-FeirTILIZATION.

SÈMI-, a Latin pretix meaning half or partial.

SĔMǏĂDHĒR'ENT, adherent halfway, as the calyx lualf-way to the summit of the ovary.

SĔMǏĂMPLĔX'ǏCAUL, slightly clasping the stem.

SĚMǏẢNĂT'RŌPOǓS, see ANPHITROPOLS.

SĚMǏCōLŬM'NAR, see SEMITERETE.

SĚMǏCôR DÁTE, in the shape of a lateral half of a cordate body.

SĔ'ǏDOǓBLE, when a nart onls of the stamens are replaced by petals. Compare FcLL.

SĔMǏĔQUǏTANT, see HALFEQUITANT.

SĚM'ǏFLŌRĚT, a floret in Compositæ having a strap-shaped corolla; ligulate floret; semithoseule.

SĚMǏFLǑS'CŪLAR, having the florets of a head in Compositæ all ligulate; semitlosculous.
SĔMǏFLŏs'CŪLE, see SEMIFLORET.

SĚMǏFLǑS'CŪLOǓS, see SEMIFLOSCLLAR.

SĚMǏLĚNTÍC'ŪLAR, see SUBLEXTICCLAR.

SĚMǏLŏC'ŨLAR, having the dissepiments incomplete and the pericarp therefore really unilocular; semiseptate.

SĚMǏLÜ'NAR, see LUNAR.

SĚMILLŨ'NĀTE, see LUXAR.

SĚM'ǏNAL, pertaining to seed.

SĔM'ǏNAL LEAF, see COTYLEDOX.

SĚM'ǏNAL SPŌRT, see SEEDSPORT.

SĚMINNA'TION, the production of seeds. Sometimes used for their dissemination or disper. sion.

SĚMǏNǏF'ẼROǓS, seed-beariug.

SĚMǏÔRBǏC'ÜLAR, in the shape of one half of a circular body. Compare StborbictlaR.

SĔMĪōVAL, having tlie shape of half of an oral, divided lengthwise.

SĚMǏ̄̄ VĀTE, in the form of half of an ovate figure, divided lengthwise, as where one side of an otherwise ovate leaf is wanting.

SĚMǏRÁ'D广̄ĀTE, having a part only of the marginal florets of a head ligulate.

SĔMĬRĔN'ǏFÔRM, reniform, with one lobe wanting.

SĚMǏSĂG'ǏTTĀTE, sagittate, with one lobe wantivg.

SĚMǏSĚP'TĀTE, see SEMILOCLLAR.

SĚMǏSTĂM'ǏNĀTE, for merly sometimes used for semidouble. SĔMǏTERĒTE', half-terete; halfcylindrical; semicolumuar. 
SĚMǏVĂL'VĀTE, applied to a pericarle in which the valves are ouly partially deliscent.

SĚMǏVÈRTǏÇ'ǏLLĀTE, see SUBVERTICILLATE.

SĔMPẼRVI'RENT, see EvERGREEN.

SĚN'SİTIVVENĚSS, see IlßRITABILI'T:

SE'PAL, a leaf or lobe of a calyx.

SÉP'ALINE, pertaiuing to or renenuling a sepal.

SĒPǍL'ŌDY̌, the reversion of petals to sepals.

SËP'ALOID, sepal-like.

SĚP'ALOǓS, latving or relating to sepals; sepaline.

SĚP'ÁRĀTE, see FrEe aud DisTINCT

SÉP'ẢRĀTĚD FLOW'ẼRS, tlıose having stamens or pistils but not both.

SĚP'ÁRĀTǏNG LĀY'ÈR, s e e ABsciss LAYER.

SĔP'TÁ, pl., see SEPTUג.

SĔPTĂM'ẼROǓS, having the parts in sevens.

SĚP'TÄTE, having one or more partitions (septa). Compare SEPTIFELIOUS.

SĚP'TĀTE SPŌRE, see COMPOUND SPOIEE.

SĔP'TĔNĀTE, having seven parts, or the parts in seveus; septamerons.

SĚPTǏCI DAL, a mode of dehiscence in which the separation takes place through the partitions, i.e., along the line of junction of the carpels. Compare Septifragal and LoceLICIDAL.

SĚPTǏF'ẼROǓS, bearing one or more partitions or septa-silil of the valves of certain calpsules after dehiscence. Compare SEPTATE.
SÉP'TǏFÔRM, resembling a septiim.

SĚPTǏF'RẢGAL, a mode of dehiscence in which the valves break away from the septa or partitions. Complure SEPTICIDAL and Loculicidat.

SĚP'TŨLĀTE, imperfectly or rarely septate, or having false or supernumerary septa.

SĔP'TŪLǓM (pl. Sěp'tūlà), diminutive of septum: a little septum or partition. Also a spurious or superumerary septum.

SĚP'TŬM (pl. Sěp'tá), a partition of any kind, is between two cells in a tissue, ol between cavities in an ovary. See DrsSEPIJENT.

SE' $\mathbf{R} \mathbf{I} \mathbf{A}$, in rows or regular succession.

SẼ RĪĀTE, see SERLAL.

SERIĆ'EOŬS, silliy; covered with fine, straight, soft, sulooth, glossy, appressed hiairs.

SE'RIẼS, (1) a row or lank: (2) a ter'm applied to various subordinate groups of different values, and also used by Asa Gray as equivilent to Subkiugdom, which see.

SEROT'ÍTNOǓS, occurring late, or comparatively late, in the seaS() 11 .

SĚR'RĀTE, laving sharp marginil teeth projecting toward the apex.

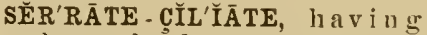
the teeth of a serrate margin tipped with fine slender hairs.

SĔR'RĀTĚD, see SERRATE.

SĔR'RATTURE, one of the teeth of a serrate margin. Compare SERrulation.

SĔR'R IED, close together in rows, like the kernels in the rows upon an ear of Indian corru.

SĚR'RỤLĀTE, diminntive of Ser- 
rate; serrate with small teeth. Compare Subserrate.

SĔR'RỤLĀTẼD, see SerRULATE.

SĚRRULLA $\bar{A}^{\prime} T I O N$, (1) the state or condition of beiug serrulate; (2) a tooth of a serrulate margin. Compare Serrature.

SĚS'QUĬ-ĂL'TẼR, half as mauy more: applied to stamens when half as many more than the petals; also to a fertile floret in grasses when accompanied by a small abortive one.

SĚS'SǏLE, (1) having no stalk, as a leaf which bas no petiole but is seated dircetly upon the stem; (2) cuiescent, not moving about - applied to baeteria and zoöspores at certain times.

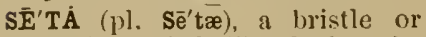
slender bristle-like body; the stalk of the capsule in most mosses above the true stem.

SĒTA' $\bar{A}^{\prime} \mathbf{C E O U ̌ S , ~ ( 1 ) ~ b r i s t l e - s l ı a p e d ; ~}$ setiform; ( (2) setigerous.

SĒTǏF'ẼROǓs, see SETIGEROUS.

SE'TIIFÔRM, see SETACEOUS.

SĒTÍG'ẼROǓs, bristle - bearing; setiferous. See Setose.

SĒTŌSE', beariug or abounding with bristles; bristly; setaceous; setous; setiferous; setigerous.

S'̄'TOǓS, see SETOSE.

SĚT'ŨLA் (pl. Sět'ūlæ), diminutive of Seta.

SĚT'ŪLŌSE, bearing nimute bristles.

SEX-, Latin for six. See HEx-.

s.s. one of the attributes of nearly all living bodies, which manifests itself in a certain method of reproduction, the first stage of which is the blending of the contents of two cells which are usually of distiuct character and different origin, one of whieh is called male, the other femile.
SĚXĂN'GŪLAR, having six angles; liexagoual.

SĚXF $\bar{A}^{\prime}$ RǏOǓS, six-rowed.

SĚX'ǏFID, six-cleft.

SĚXLǑC'ŪLAR, having six cells in an ovary.

SĚX'PÄRTĪTE, six-parted.

SĚX'ŨAL ĞĚNÊRA'TION, the generation or stage which bears the sexual organs in plants which bave as alternation of generations. In ferus it is the protballus. Compare Asexual Generatiox.

Š̌X' ŪAL SY̌S'TĚM, see LINNæAN SYSTEM.

SHĂG'GY̆, either villose or hirsute.

SHEATH, the petiole or base of the leaf in grasses which surrounds the stem; any tubular purt surrounding auotber ; vagina.

SHEATHED, surrounded by a sheath; invaginated; vaginate.

SHËATH'ǏNG, surrounding a stem or other body in a convolute or tubular mauner, as the petioles of grasses; vaginant. Compare diplexicaul.

SHĚLL, the bouy covering of a nut.

SHIĒLD, see APothecium and INDUsiuy. In Chara one of the eight flat cells forming the wall of the globule.

SHIELD - SHÄPED, scutate or peltate.

sHo0T, a young growing branch or twig, or an unusually vigorous stem or branch, generally from the ground or near it. Also nsed by botanists as a general term for the stem or leaf-bearing part of a plant in distiuction from the root.

SHRŬB, a woody plant which seldom exceeds twenty feet in 
height; especially one having several stems. ('ompare Bush, Undershirub, and Tree.

sÍc'cưs, dry.

SIEVE-ÇĔLL, see SIEVE-TUBE.

SǏEVE-DǏsK, the perforited septim between the ends of adjoining sieve-tubes; sieve-plate.

SİEVE-PLĀTE, see SIEVE-DISK.

SİEVE-PŌRES, the perforatious in a sieve-disk.

SǏEVE-TŪBE, a for'm of vessel characteristic of the phloëm portion of fibrovascular burdles. Sieve-tubes consist of elongated, thin - walled cells, united end to end in rows, with the transverse septa (sieve-dislis) perfortted in a sieve-like manner so that the protoplasm is continuous from one vessel to auother; sievecell; clathrate-cell; bast-vessel.

SĬG'ILLĀTE, appearing as if marked with impressions of a seal, as the rootstock of Solomon's seal.

SIG'M $M \overline{O I D}$, curved in two directions, like the Greek sigma or letter $\mathrm{S}$.

sIL'ǏCLE, a short silique, as that of sheplierd's-purse.

SǏLǏC' ŪLÁ (pl. Sĩlìc'ūlæ), see SILICLE.

SİL'ǏCŪLE, see SILICLE.

SǏLIC'ŪLŌSE, having silicles, or resembling a silicle.

SĬL'ǏQUA் (pl. Sĭl'íquæ), see SILIQUE.

SILIQUE [pro. Sĭ-lēk' ${ }^{\prime}$, the fruit in Crucifera-a pod of two carpels, which separate in debiscence from a frame-like placenta called a replum; siliqua.

SĬL'ǏQUŌSE, resembliug or bearing siliques.
SǏLK, the style of Indian corn.

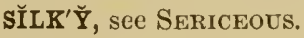

SĬL'VA், see SYLVA.

SIL'VẼR GRĀIN, plates of medullary ralys which appear as glim. mering spots upon the surface of wood when split radially. See Medullary Ray.

SILL'VẼRY̆, white, tiuged with bluish graly, and having it metallic lustre.

SÍM'PLE, without subdivisions; entire; unbranched. Compare Compound.

SǏM'PLE FRUIT, one derived from a single flower containing a single pistil. Compare Collective Fruet and ComPOUND FREIT.

SǏM'PLE LĒEA, any leaf which loes not have distinct subordinate leaflets, though it may be lober. Compare Cosmound LEAF.

SǏM'PLE NŨTÁ'TION, see NUTATron. Compare CincumataTION.

SİM'PLE PǏS'TǏL, one consisting of a siugle carpel.

SǏM'PLE PǏT, one having no more than a slight enlargement at the centre where the pits of adjoining cells meet (simple pore of Gregory). Compare Bordered Pit.

SĬM'PLE PŌRE (Gregoly), see SiNPLE Pit.

SĬM'PLE PRI'MẢR root.

SǏM PLE SPŌ'RŌPHŌRE, a sporophore cousisting of a single hypha or hyphal brauch: filamentous sporophore. Compare CoMpound SPOROPHoRE.

SĬM'PLE STĔM, an unbrinclied stem.

SĪMǓLTA'N'NẼOŬS WHORL, one whose members originate si- 
multaneously. (Sachs.) Compare Successive IVhori.

SIN'GLE, saicl of a flower which lias but one set or whorl of petals. Compare Double, Semidouble, and FulL.

SǏN'ǏSTRôRSE, turning or twining to the left; said of a twining stem which turus in the opposite direction to the sun or hands of a wateh. See remarks under DextroRse.

SIN' 'ŨĀTE, strongly wavy ou the margin, with large alternate convexities and concavities. Compare Repand and UnduLATE.

SǏN ŪoǓS, flexuose; curving back and forth.

SI'NǓS, a cavity or recess, either rommled or angular, in the margin of a leat or other orgau.

Sİ PHǑN, n large tubular cell in ('hara and virions algæ.

SĬ'TĚR-ÇĔLL, a cell of the same origin as another: thus, if several cells arise simultaueously by free cell-formation withiu another, as in the development of pollen, they are called sistercells with reference io carh other, and the same term is applied to the relution existing ing betreen two or more cells which arise by the division of a single cell in ordinary growth. Compare Motier-cell and DAUGHTEL-CEILL.

SKEIN, a condition of the chromatin of the nucleus in the tirst and last stages of liaryokinesis when the nuclear filament is emerging from or passing into its reticulated condition in the resting nucleus; mother-coil; tangle.

SKĬN, auy soft, thin covering, especially if easily lemovable; cuticle; epidermis. Compare RIND.
SLǍSHED, see LACINIATE.

SLEEP, a condition assumed by certain plants, usually upon the withlrawal of light, as at night, in which the flowers remporarily close, and the leaves or leatiets droop or fold together.

SMALL FRƯITS, a horticultural term for certain low-growing, perennial, fruit-bearing plants and their product, ineluding the strawberry, raspberry, blackberry, gooseberry, currant, huckleberry, and cranherry. The teim includes grapes, but excludes cherries.

SM00TH, see Glabrous.

s0̄'BÖLE, an old and useless term, usually meaning stolon, but sometimes and more properly a sucker or slender shoot from the ground or base of the stem; soboles.

SǑB' ŌL Ȩ̇ (n., sing.), see SoBOLE.

sōçAL, growing naturally together, so as to occuipy a consirlerable extent of ground with indivicluals of the same species; gregarious. Compare CFsPJTOSE.

SǑFT BÁST, the' sieve-tubes, together with any other mulignified portion of the phloem.

SŌLE

sŏL'ÍD, without either cavities or separable articulations; continuous.

\section{SŎL'ĬD BŬLB, see CorMI.}

SǑL'ǏTĀRY̆, siugle, not closely associated with other objects of the same kind, as flowers which grow one upon a stem, or plants which do not grow in groups or masses. Compare SOCIAL.

sōLŪTE', free; not adhering: opposed to Adnate, as a solute stipule. 
SOLU'TION, the isolation or sepa. ration of whorls (apostasis), or of organs or parts which are usually close together or adherent. Compare Dialrsis.

Sō'MÁ (pl. Sō'màtá), a small body or grauule of any kind. Conspare Hicrosoma.

sōMǍT'ǏC CELLS, cells forming a part of the bonly of the indiviclusl, not modlified for any particular purpose; especially the growtli-cells of an organism, in (listinction from repro. ductive cells of any lind.

sōMȦTŏT'RŌPİșM, an influence which the substratum exerts on the direction of growth of certain plauts andorgans. Thus the hypocotyl of the mistletoe is directed towarl the branch (positive somatotropism) aud the stem at first anay from it (negative somatotropism) upou whatever sisle of the brauch the seed is situated.

SôR'DÍd, of a dirty white or mudily color.

SŌRE'DİA, pl., see SoREDICI.

SŌRE'DİAL BRANCH, a branch produced by the development of a soredium into a new thallus while still on the motherthallus.

SŌRË'DİĀTE, see SoREDIFERoU's. SǑRĒDǏF ẼROǓs, bearing soredia; sorediate.

SōRE' $\bar{E}^{\prime} \mathbf{D} \check{\text { Ư M }}$ (pl. Sōrē'dià), a single gonidial cell or group of gonidia in lichens. surronuded by a weft of hyphæ, which is thrust out of the thallus and grows directly into a new lichen; brood-bud.

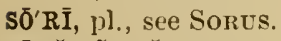

SŌRIF'ẼROǓS, bearing sori.

sō'RŌSE, (1) heaped or clustered together; (2) bearing a sorosis, or in the form of a sorosis.
Sōßō'sǏs (11. Sōrō'sēs), a collective fruit, cousisting of a consolidated fleslyy spilie, as the mulberry and pineapple.

SǒR'RŌWFựL FLOW'ẼRS, tlıose which exhale their olors only at certain hours of the dily, as Pelargonium triste. (Rare.)

sō RỨs (pl. Sṓrī), ‘ heal) or collection of spores or other objects, ats a "fruit-dot" or group of sporangia in ferus.

SPẢDĬ ÇEOǓS, resembling or bearing a spaclix.

SP $\bar{A}^{\prime} D I C O \bar{C} S E$, resembling a spadix. SPA'DIX a spike, usually tleshy, enclosed within a spathe.

SPĂN, the space between the tip of the thumb and that of the little finger, separated as widely as possible: nine inches.

SPÄRSE, few and scattered.

SPA' $\bar{A}^{\prime} T H \dot{A}$, see SPA'THE.

SPAंTHA'ACEOǓS, bearing or resembling a spathe; spathose.

SPA THAL, furnished with a spathe. (Rare).

SPÄTHE, a large bract, usually colored, enclosing or subtending an inflorescence, which is geverally a spike (spadix).

SPẢTHĔL'LA (pl. Spàthěl'læ) (rare), (1) a glume in grasses; (2) a spathilla.

SPẢTHǏL'LA (pl. Spàthìl'ææ), a diminutive or secoulary spathe, as in palms.

SPĂTH'ŌSE, see SPATHACEOU'.

SPĂTH'ŪLĀTE, see SPATULATE.

SPĂT'ŪLĀTE, flat, with a linear base and griulually rounded summit, like a druggist's spatula; spatulate.

SPAWN, the mycelium of mushrooms; occasionally applied to that of some other fungi

SPE'CIES, the lowest well-defined natural gromp of plants, the 
individuals of which differ but slightly among themselves and are sharply distinguished from those of other groups. T'liey reproduce themselves from seed for successive generations with little or no variation. Compare Gexus and VARIETY.

SPE' ÇIES-HȲ'BRĪD, see HYBRID. SPĒÇIF' ǏC, relating to species.

SPËC̆ǏF'ĬC €HĂR'ĂCTẼRS, the features which distinguish the plants of one species from those of all others.

SPĒÇĬF'ĬC NĀME, the name of the species, forming a part of the botanical name; trivial name.

SPĚÇ'IMEN, a plant or portion of a plant prepared and preserver for study.

SPẼR'MÄGōNE, see SPERMrogoNIUM.

SPẼRMȦGō'NIUัM, see SPERMOGONIUM.

SPẼR'MÁPHŌRE, see SPERMOPIIORE.

SPẼRMÀTĬF'ẼROǓs, b e a ring spermatia.

SPẼRM Á 'TǏ ŬM (pl. Spẽrmā'tìa), a non-motile male gamete (spermatozoid) in the red alga. Also applied to certain minute non-germinating sporelike bodies in fungi, some of which have been regarded as functionless male gametes. Many of these are now known to be stylospores capable of germination.

SPẼR'MÄTŌÇY̌ST, the mothercell of a spermatozoirl.

SPẼRMȦTŌZŌİD, see ANTHEROzOID and SPERnATIUM.

SPẼRMȦTŌZŌó̄N (pl. Spermàtōzóä), see ANTHERozoID.

SPẼRM - ÇELL, a male repro- ductive cell (gamete). Com. pare GEKM-CELL.

SPẼRM'ǏC, pertaining to seed.

SPẼRMĬD'Ǐ ŬM (pl. Sperrmíd'ía), an old term for achenium.

SPẼRM-NU'CLẼUS, the nucleus of a male gamete (male prouncleus) which coalesces witl the nucleus of a female gamete (female pronucleus) to torm a germ-nuclens; spermo-nueleus. In the pollen-tube it is called the generative nuclens, which see.

SPẼR'MŌDẼRM, the covering of a seed, consisting of the several coats taken together; seedcoat.

SPẼRMŌGō'NǏŬM (j). Spêrmōgō' . nìa), a cell or receptacle in which spermatia are produced,

SPẼRMŌ-NŨ'CLẼUS, see SI'ERMNCCLEUS.

SPẼR'MŌPHŌRE, an old term, applied both to funieulus and placenta. See Trophospenar.

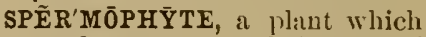
produces true seerls instead of spores; a floweriug plant.

SPẼROTTHĒ'CÁ, an oll telm for perictrp.

SPẼR'MOǓS, see SPERMIC.

SPHĂC'Ẽ ẼTE, dark and withered as though dying or (lead; like a splıacelium.

SPHȦÇE'L $\bar{I}^{\prime} \dot{A}$, a former genus of fungi, now linown to be the first or conidia-bearing strge of Claviceps when it appears as the spur or ergot.

SPHẢÇÉ'LIUUM, sce SPIYACELIA.

SPH ĖRAPH'IDẼS, sphere - crystals, especially if composed of needle-shajed parts.

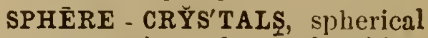
aggregations of crystals, either irregularly united or having a radiating structure. Compare 
Cystoliti and SPHÆRAPHIDES.

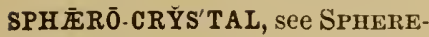
CRYSTAL.

SPI'CATTE, arranged in a spike; spike-like; spicose.

SPIÇǏF'ẼROŪS, bearing or prolucing spikes.

SPİ'ÇǏFôRM, spike-shaped.

SPİCÖSE', bearing spikes or arranged in spilies; spicous.

SPǏC'ŪLA் (pl. Spic'ūlæ), see SPICULE.

SPÍC'ULAR, resembling a spicule or bearing spicules.

SPIC'ŨLĀTE, (1) covered with spicules; (2) bearing or composed of spikelets. (Rare.)

SPǏCŨL' $\bar{A}^{\prime}$ TION, a term employed by Nylinder for an atteunated constriction of the hypha in the formation of spores, leav. ing the extremity as a spicule after the separation.

SPǏC'ÜLE, (1) a small pointed appendage somewhat soft or fleshy, like the sterigmata of fungi; (2) a needle-like crystal; (3) a spikelet (obs.); spicula.

SPİKE, an inflorescence of sessile or nearly sessile flowers on a single elongated axis. See SPADIX, AMENT, SPIKELET, and Compound Splke.

SPĪKE'LĚT, (1) a secondary spike; (2) in grasses a Hower (or ultimate flower - cluster) ususally enclosed by one or more (generally two) empty glumes; Jocustil.

SPǏN'DLE, (1) a name sometimes given to the tassel of Indian corn; (2) see Nuclear SpINDLE.

SPIN'DLE - FI'BRES, the achromatic filaments which form the nuclear spiudle; spindle- threads; nuclear fibrils and cell-fibres of Strasburger; conjunctive threads of Fol (probably).

SPǏN'DLE - SHĀPED, see FusIFORM.

SPĪNE, any sharp, rigid process of considerable size which is not il transformed branch; especially an organ, such is a leaf, stipule, tooth, etc., of whatever size, which is modified by becoming sharp and rigid for protection. In general, where no other distinction exists, as in the cactus, spines are considered merely as shurp processes intermediate in size aud rigidity between thorns and prickles. See Trois and PRICKLE.

SPĪNĚS'ÇENT, somewhat spiny in structure, or bearing fer spines. Compare SPINUlesCENT.

SPINN ǏF'ẼROǓS, bearing a spine or spines; spinigerous.

SPIN' IFF̂RM, shaped like a spine or thorn.

SPINN ǏG'ẼROǓS, see SPINIFEROCS.

SPĪNŌSE', bearing spines; covered with spines; spinous; spiny.

SPI'NOǓs, spinose or spiuy.

SPǏN'ŪLE, a very small spine.

SPǏNŪLĚS'ÇENT, slightly spiuy in structure, or bearing small spiues; spiuulose. Compare SPINESCENT,

SPǏNŪLIF'ẼROǓS, bearing very small spines.

SPǏN'ŪLŌSE, spinulescent; especially, bearing many small spines.

SPIN' ${ }^{\prime}$, bearing spines; having the nature of a spine; terminating in a spine. 
SPI'RAL DǓCT, see SPIRAL VESSEL.

SPI'RAL MÄRK' ÍNG, the spiral fibrous thickening characteristic of spiral ducts or vessels.

SPI'RAL VĚS'SĔL, a duct or vessel having fibrous thickeniugs upon the wall in the form of a coil or spiral. Formerly called Trachea.

SPİRE, (1) il young leaf or shoot of grass; (2) the coutinuation of the trunk, in excurrent trees like pines, above the insertion of the lowest branches: (3) one turn of a coil or spiral.

SPI'RĬCLE, a minute spiral thread or tilameut.

SPİTH'ÄMÁ (obs.), see SPAX.

SPLĂSHED (Hol't.), ha ring broken stripes of various sizes. Used mainly in describing the coloring of apples.

SPLIT, the same as Parted. (Olos.)

SPON'ĞL̄LE, a ter'm formerly applied to the extreme apex of growing roots, which was erroneonsly supposed to be devoid of epidermis and specially fitted for the absorption of food from the soil. See ROOT-CAP.

SPǑNTA' NẼOǓS GĔNEัRA'TION, the development of living orgauisms from dead or inorganic matter; equirocal generation; heterogenesis; ahiogunesis; autogenesis. T'he theory of spontaneous generation is not now held by scientists.

SPOON'FôRM, having the inuer surface of a leaf concave or dish-shaped, as the outer leaves of a cabbage-head. (E. S. Goti.)

SPŌRĂD' IC, scattered; occurring alpart from others of the same kind.
SPŌRĂNGE', see SPORANGIUM. SPŌRĂNǴĬ'ǏŬM, (1) the columella in mosses; (2) a sporaugium. (Rale.)

SPŌRĂN'Ǵ̄̄ōE, au old tel'm for Ascus. Also applied to a small sporaugium prodnced in some genera of Mucoriui in addition to the large form, the spores beiug similar in both; spor:tugiolum.

SPŌRĂNGI'ŌLǓM, see SPORAXGIOLE.

SPŌRĂN'ĞĪOPHŌRE, the stalk, support, or receptacle of a sporangimm, including suclı supports as the sporophyll in Equisetacee and the axis or colmmella from which the sporangia arise in the sori of certain ferus.

SPŌRĂNĞǏOTH'ŌRŬM, se e SPORATIIOPHORE.

SPC̄RĂN'ǴĬŬM (pl. Spōrăn'ğìa), any case or capsule immediately enclosing spores. Ap. plied chiefly to certaiu kiuds which have not received specinl names, such as the sporecases of ferns aud the Mucoriui, and rarely used for Ascus, cluster-cup, aud otlier named formis.

SPŌRE, one of the reproductive bodies of cryptogams which take the place of the seeds of flowering plants, but from which they differ in containing no embryo. Sprores usually and properly consist of but one cell, which differs materially in character from the other cells of the plant. They may thus be distinguished from gemma. produced by comparatively few plants, which usually contain a number of cells only slightly differing from those of the plant produciug them. In a 
lestricted semse, proposed by Sachs, the term spore is applied to reproductive bodies which arise either directly $\mathrm{or}^{\circ}$ indirectly as the result of fertilization, in distinction from gonidium, which is applied to those produced asexually. Spores in this restricted sense are by De Bary termed carpospores. See Ecloiospore, Macluospore, Oöspore, ProTospore, Teleutuspore, T'ETRASPORE, ÚREDOSPOIE, ZOÖSPOLE, ZYGOSPURE, etc.

SPōRE-CĀSE, see Sporangiudr.

SPŌRE-CĚLL, a spore, or a cell which gives rise to a spore.

SPÖRE-GROUP, see COMPOUND SPOIRE.

SPŌ'RÍD, see SporidiuM.

SPŌ'RĬDĔSYM, see COMPOUND SPORE.

SPŌRĪD'ǏŬM (p). Spōríd'ìa), a spore produced upon a pro. mycelium; germ-cell; secondary spore. Formerly applied to any spore, especially if very small, and still improperly used for A scospore.

SPŌRǏF'ẼROǓS, spore-bearing.

SPŌRŌCÄRP, a groul) of spores resulting from fertilization, together with enclosing or attendant parts. It is thus the fructification developed from an archicarp or procarp in fungi and Rholopliycex; also the sporogoninm in mosses. The term is also used for the bouly enclosing the sporangia in heterosporous Filicinex. Compare SPOROGONIUM.

SPŌRŌCÄR'PǏŬM, see SPoroCARP.

SPŌRŌCL $\bar{A}^{\prime} \mathbf{D}$ ǏM, a spore-bearing branch, as a sticlidium in Floridex.
SPŌ'RōÇY̌sT, the mother-cell of a spore; sporocyte: occasionally also applied to certain sporangia in algæ.

SPŌ'RōCȲTE (Goebel), see SPoHOCY'ST.

SPŌ'RōDẼRM, the coat or covering of a spore, including exospore and enclospare. Compare SPERMODERM.

SPŌRŌDō'EHǏŬM (pl. Spōrōdō'chỉa), a spore-benring or sporeholding apparatus. Applier mainly to the sporiferous mass, including the spores, in the Tuberculariex.

SPŌ'RōGĚN, a plant which produces spores; cryptogan. Compare SPERHOPHYTE.

SPŌ'RŌGŌNE, see SPOROG(NIITs. SPŌRōGō'NǏŬM (pl. Spōrōgóñiả). the whole prodnct of the sexual act in the higher cryptogams; asexual generation; sporophore: sporophyte; oüphyte. In ferns it is the segment or stage in the life-cycle which we see as the ordinary fernplint. Compare Prothalios.

SPŌ'ROID, spore-like.

SPO'RŌPHŌRE, a stalk supporting one or more spores; any spore-bearing apparatus or receptacle, such as a gonidiophore, sporangiopliore, or ascophore; pirticularly the second or asexual generation in plants having a distinct alteruation of generations, such as ferns and mosses (sporogoninim). C'ompare OõpHore. See Simple SPoroPHORE, CoMPOEND SPOROPHORE, and BASIDIUI.

SPŌRŌPHY̌L, the same as Sporophyll or Sporophyllum and a spelling now in frequent use. SPŌ'RÖPHY̌LL, see SPOROPIYLLUAr. 
SPŌRŌPHY̌L'LǓM (pl. Spōrōphy̆l'lä), a spore-bearing leaf of any kind; sporophyl. Formerly applied to leaf-]ike lobes of the thallus in algæ betring tetraspores.

SPŌ'RŌPHȲTE, see SPOROGONIL'M.

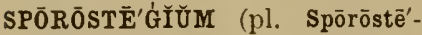
ġia). the oösporangium or fruit (uncule) of the Charizcer.

SPŌRT, a plant, or portion of a plant, which has suddenly assumed an appearance very different from that characteristic of the variety or species; a seed- or bull-variation, but said mainly of the latter. Its peculiarity is not usually capable of being perpetuated by seed. When a sport is propagated artificially it contiuues to be called a sport. Monstrosities or extreme malformations are not usually given this name. See Variation, SeedVARIATION, and BUd-VARIATION.

SPǑRŪLA'TION, the production of spores.

SPǑR'ŪLE, a small spore. Often unsuitably applied to ascospores. Compare SPoridium.

ȘPŏRULǏF' ĚROǓs, producing sporules.

SPǑRŪLÍG' ẼROǓs, see SPORULIFEROUS.

SPǑT'TĔD, covered with large lots: said of fruits.

SPRAWLS, a local or obsolete term for small branches or twigs.

SPRĔAD'ǏNG, said of branches which bend outward considerably, but at less than a right angle.

SPROUT, any quickly grown part, as a young root or stem from the seed, or a vigorous branch arising from the root or stem. See WATER.SPRoUT.

SPROUT-ÇĚLL, in fungi, a cell produced by sprouting or pullulation.

SPROUT-CHĀIN, a rOW of united cells in fungi formed by budding (pullulation.)

SPROUTGĞM'MA, in fungi, a gemma having the form of a septate confervoid filament the segments of which are capable of sprouting. (De Bury.)

SPROUT - GẼRMINN $\bar{A}^{\prime} T I O N$, the manuer of germination of a spore in which a small process with a narrow base protrucles at one or more points on the surface of the spore, then assumes an elongated cylindrical form, and is finally detached as a sprout-cell. (De Bary.)

SPROUT'ÍNG, see PUllulatiNg and Germination.

SPŪMĚS'CENT T, resembling floth or foam; spumose.

SPŪMŌSE', sCe SPUMESCENT.

SPÛR, (1) a short, stont brancl, as those in the larch bearing a tuft of leaves or in the apple bearing the fruit; (2) a tubular appendage of a petal or sepal, usually containing nectar, as in larkspur (calcar); (3) the sclerotium of ergot.

SPU' RĨOǓS, see FALsE.

SPÜ'RǏOǓS BRÁNCH, see PsEUDORAMULES.

SPŪ'RIOǓs FRƯIT, a collective, aggregate, or accessory fruit.

SPŪ'RĪOǓS TǏS'SŪE, see FELTED Tissue.

SPU' RĨOǓS WHôRL, one which is formed by displacement and nnequal growth of the axis. (Sachs.) 
SPÛRRED, bearing a spur; calcarate.

SQUA' $\overline{\mathbf{A}}^{\prime} \mathbf{M} \dot{A}$ (pl. Squā'mæ), a seale of any kind, as one of the leaves of a luud.

SQUẢMÁ'ÇEOŬS, see SQUAMOSE.

SQUA'M $\bar{A} F O R M$, see SQUAMIFORM

SQUA'M MĀTE, see SQUAMOSE.

SQUA்MĔL'LA (pl. Squảmĕl'læ), diminutive of Squima: a small scule, as the bructs upon the lead in Compositie; squammla.

SQUẢMĚL'LĀTE, diminutive of Syuamate. See SQUAMULOSE.

SQUA்MĔLLIF' ẼROǓS, bearing squamellie.

SQUẢMĔL'LIFF̂RM, like a small scale; squamuliform.

SQUÁMǏF' ĖROUS, scale-bearing; squitnigerons; squamose.

SQUĀMǏFLŌ'ROǓS, having flowers which resemble seales or are borne upou scales.

SQU $\bar{A}^{\prime}$ MÍFÔRM, scale-shaped; squamoiel.

SQUẢMİG'ẼROŬS, see SQUAMIFEROUS.

SQUA'MOID, see SQUAMIFORM.

SQUẢMŌSE', scale-like; covered with seales; consisting of scales; squamous; squimate; squamaceons. See SquamiFokM and SqUAMIFEROUS.

SQUA'MOǓS, pertaining to seales, or squamose.

SQUA'MOǓS BǓLB, see SCALY BULB.

SQUĂM'ŨLA, see SQUAMELLA. Formerly applied to the lodicule of grasses.

SQUĂM'ŪLĀTE, seeSQUAYULOSE. SQUĂM'ÜLIFÔRM, see SQUAMEL. LIFORM.

SQUǍM'ŨL̄̄sE, diminutive of Squamose; having or resem- bling small scales; squamellate; squamulate.

SQUẠRRŌSE', luving lateral orcrans, as leaves, extending at ibont right angles to the axis.

SQUĂR'RULŌSE, s 0 me w h a t squarrose.

STĂG'-HĚADĚD, a term applied in forestry to a tree which is dying at the top.

STÄINED, faintly colored-applied to fruits.

STALKED GLAND, see GLANDULAR HAIR.

STALK'LET, a secondary or very small stalk. See SEcondary Petrole and Secondali PeDUNCLE.

STA $\bar{A}^{\prime} \mathbf{M E N}$, the pollen-bearing organ of a flower, usually consisting of an anther, or part immediately enclosing the pollen, and a filament or stalk.

STĂM'ǏNAL (obs.), see ŚTAMINATE.

STĂM'ǏNĀTE, pertuining to stamens; containing stamens but no pistils-silid of a plant or hower. See STamineal.

STAMY̌N'EAL, formed of stamens; attached to stamens; having marked reference to stamens; stamineous; staminate.

STẢMǏN'ẼAL CǑL'ŬMN, s e e AXDROPHORE.

STȦMǏN'ẼOǓS, see STAMINEAL.

STĂMǏNǏD'ǏŬM (pl. Stăminñd'ĩa) (obs.), see ANTHERIDIUA.

STĂMǏNIF'ẼROǓS, bearing stamens: staminigerous. Said especially of a plant or flower bearing stamens but no pistils. STĂMǏNÍG'ẼROǓS, see STAMINIFEROT'S.

STĂM'ǏNŌDE, see STAMINoDIUM. STĂMĬNō' DǏŬM (pl. Stăminō'dià), an altered, abortive, and sterile stamen, or body ocenpying the 
place of a stamen; staminode; parastemon. See LEPAL.

STĂM'ÍNŌDY̌, the conversion of other organs of a Hower into stanteus.

STĂM'ǏNŌSE, having the stamens unusually large or numerous. (Rare.)

STĂND'ARD, see VEXILIUA. In horticulture (1) a tree or shrub which stands alowe withont being attached to any wall or support, as distiuguished from an expalier or curdon; (2) a shrub, as a rose, grafted on au upright stem or trained to a single stem in tree form; (3) in the United States, i fruit-tree grafted upon a freegrowing as opposed to one upon a lwarf stock.

STÄRCH - BUǏLD'ẼR, a plisstid, generally a leucoplast, in which a starch-grain originates. See C'nRoMA'TOPHOLE.

STÄRCH - GRĀIN, the grain of starch as it cxists in the living plant. It is of definite shape, varying according to species, but always rounded, and formed of successive layers (or appatrently so) having a common, and usually eccentric, centre.

STÄRCH-LĀY'ẼR, a terun sometimes applied to the bundlesheath, which often serves especially for the storage of starch.

STÄRCH-STÄR, a form of bulbil in Cleare stelligera, consisting of an underground node.

STÄR'RỸ, see S'TELLATE.

STÄRVED, see DEPAUPERATE.

STÁ'SIYMÔRPHY̌, a changell condition of form or size arising from arrested development.

STA'TION, a particular limited locality, without regard to character or exposure, in which a species is found. Compare Regron, HabitaTIUN als Habitat.

STĂT'ŌSPŌRE, see RestiNGSPORE.

STÉGŌCÄR'POǓs, applied to capsules in mosses which have a distinct lid or opereulum.

STĚL'LĀTE, star-shaped; radiatiug.

STĚL'LĀTE HÂIR, a bair having several branches arranged in the form of a star, as the hairs of Malpighiacez.

STĚL'IŪLAR, See STELLULATE.

STĚL'LŪLĀTE, dininutive of stellate; resembling a little star; stellular.

STĔM, see Trunk, Peduncle Pedicel and Petiole.

STĚM-CLȦSP'ǏNG, see AMPLEXICAUL.

STĚM-LEAF, a leaf growing from the stem above the ground. Compare Radical Leaf.

STĚM'LĚSS, SE ACAULESCENT.

STĚM'LET, a little stem; the first internole above the cotyledons.

STĔM， SŬBTĔRRA' $\bar{A}^{\prime} \bar{E} A N$, see SUbTerRaNeAN STEM.

STĚM-TĚN'DRIL, a tendril which is a transformed stem, as in the grape. Compare LEAFTENDRIL.

STĚNŌPĚT'ALOǓS, having narrow petals.

STËNǑPH'Y̌LLOǓS, \ A T Y O W • leaved. Compare LAtrifolious.

STĒNō'SǏs, (1) cell-fol'mation in which there is a direct con. striction of the walls of the original cell, as in budding. Compare Crtodieresis. (2) The patloological narrowing of a passage. 
STE'REIJD, a cell of stereome, which see.

STE'RĒōME, strengtheniug tissue: it term applied by Schwendener to that part of a fibrovascular bundle to which it chiefly owes its strength; also to the cortex on physiological grounds, it often serving mainly for support. Compare Mestume.

STE RĒ̄PLĂSM, the solid portion of protoplasin. (Nïgeli.) Conıpate HYGROPLASM.

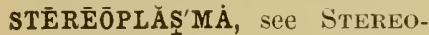
PLASM.

STËR̆G'MÁ (pl. Stērĭg'màtà), (1) the downward prolongation of a decurrent leaf upon the stem; (2) a very narrow support to a spore, as the pointed protuberances upon basilia, of the filaments bearing spermatia and stylospores.

STĚR'ǏLE, (1) unfruitful; barren -as a plant which fails to blossom or fruit, a pericarp which contains uo seeds, $O I^{\prime}$ il stamen which produces no perfect pollen: (2) devoid of living organisms-used mainly in bacteriology.

STĚR'ÍLE FLOW'ẼR, one coltaining no perfect pistils. It may or may not contain stamens.

STĚR' ILLIZE, to render free from all living bodies, as fluids in which bacteria are to be culti. vated.

STẼR'NŌTRĪBE, a ter.1 applied to zygomorphic flowers which have the stamens so placed that a visiting insect will receive the pollen upon its minder surface, as in most Papilionacere. Compare Nototuibe and Pleurotribe.

STER'ÖM, see STEREOME.
STǏ€HǏD'ǏŬM (pl. Stǐєhŭd'íá), a branch of the thallus in red algæ (Florideæ) containing tetraspores.

STIG'MA, the part of the pistil which receives the pollen. It is usually the apex of the style, variously expanded, which is destitute of epiclemis and secretes the "stigmatic Huid," which see.

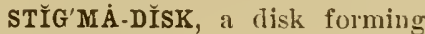
the seat of a stigma, as in Asclepias.

STǏGMĂT'ǏC CĔLLS OF THE ÄR€HĒGŌ'NǏŬM, see L I DCELLS.

STĬGMĂT'ĬC CHĀM'BẼR, the part of the rostellmm in orchids in which the viscid disk or retinaculum is leveloped. (Functionless as a stignul.)

STĬGMĂT' IC FLU ǏD, a visciil Huid secreted by the stigma at maturity which serves to hold the pollew, and in which the pollen-grains germinate as the first stage of fertilization.

STĪLŌGŌNǏD'ǏUM, see STYLOSPORE.

STǏM' ULŌSE, covered with stingiug hairs.

STǏM'ŪLŬS ( $p l$. Stĩm'ūlì), see STINGING-IIAIR.

STǏNG, see STINGING-IIAIR.

STǏNG'ǏNG-HÂIR, al glandulır hair which secretes an acrid fluid; sting: stimulus.

STİPE, a term applied to various kinds of stalks or stems, includiug the petiole of ferns. the stalk of a mushroom, the stem of a pappus above the seed, the stalk of an ovary raising it above the receptacle, etc. Various forms of stipes in flowering plants are distinguished under the terms the caphore, gynophore, antho- 
phore, gynobase, gonophore, curpophore.

STI'PĚL, the stipule of a leaflet.

STİPĔL'LĀTE, furnished with stipels.

STI'PĒS, an uncommon spelling of Stipe.

STI'PǏFôRM, resembling a stipe; stipitiform.

STǏP'İTĀTE, having a stipe; supported on a stipe.

STǏP'ǏTIYFÔRM, see STIPIFORM. STÍP'ŪLȦ (pl. Stǐp'ūlæ), see S'TIPULE.

STǏPŪLA'CGEOǓS, SEe STIPULAR.

STǏP'ŪLAR, having stipules; formed of stipules; situated near or upon stipules; pertaining to stipules; stipulaceous.

STĬP'ŪLĀRY̌, formed of stipules.

STǏP'ŪLĀTE, having stipules; stipulated; stipuled.

STǏP'ŪLĀTĔD, see S'TIPULATE.

STIYPŨLA'TION, the situation or arrangement of the stipules.

STǏP'ŪLE, an organ situated in pairs upon the stem, one on eitler side of the petiole at its base and often adherent to it. They are usually expanded, seale-like or leaf-like, but sometimes exist in the form of glands, prickles, tendrils, or other organs, and are often wauting altogether. They frequently serve for protection to the bud or growing point, and fall away as the butl expands and the leaves develop.

STÍP'ÜLED, see STIPULATE.

STǏPŪLǏF'ẼROǓS, bearing stipules.

STİP'ŪLŌSE, having very large stipules. (Rare.)

STŏcK, (1) the persistent base of an berbaceous perennial;
(2) auy plant or part considered with reference to another part which it supports: (3) in horticulture a tree or other plant which receives a bud or graft; (4) the original or originals (parentage) of a species or variety; (5) a seedsman's term for a quantity of seed grown in a particular locality or from a particular somrce. It does not imply any peculiarity of character. Compare Striasn.

STŌLE, see STULOx.

STŌ'LǑN, a slender brauch, above or below the surface of the ground, which takes root or bears a bulb at the extremity where it forms one or more new plauts; stole; sobole. Compare Renner, RhIzome, aud OFFSE'P.

STǑLŌNǏF'ẼROǓs, bear'ing stolons.

STŌ'MÁ (pl. Stŏm'àtá), an opening in the epirlermis for the admission of air and liberation of moisture; breathing-pore. See GUARD-CELLS.

STŌ'MĀTE, see S'ToMA.

STŌMĂT ÍC, pertaining to a stoma.

STŌMĂT'ǏC ÇĚLLȘ, see GUARDCELLS.

STŌMĂT'ÍC CHĀM BẼR, the intercellular space bencaih a stoma; substomatic chamber; airchamber; respiratory chamber; respiratory cavity. See Cistone. Compare AnteCHAMBER and VESTIBULE.

STǑMÁTǏF'ẼROǓS, bearing stomata: stomatose.

STǑM'ÁTōsE, see S'TOMATIFEROUS.

STŌNE, the bony endocarp of a drupe, containing the seed; pit. 
STŌNE-FRƯIT, see DRUPE.

STOOL, a plant upon which offshoots of auy liud are produced, usually for propagation, as in the raspberry and strawberry; especially, a plant of wheat, oats, rye, or barley which has sereral stems from one root.

sт̄0I, v. i., to tiller, as grain; to throw out suckers.

STRĂG'GLǏNG, see DIVARICATE.

STRĀIN, (1) the intluence of a particular ancestor existing in an individual or variety; (¿) a seerlsman's term for a stock of seed or subordinate variety which has been bred in a special manner and aecuired a slight individual character, as "an excellent strain of Fottler's cabbage."

STRA்MǏN'ẼOŬS, like straw; especially, straw-eolored; pale Jellow.

STRĂND, a fibrovascular bundle; a branch of mycelium, or similill vegetable tiliment; specifically, a branch of fibrous mycelium, which see.

STRĂN'GŪLATĚLD, applied to a root or stem which is contracted at intervals, as though growth had been restrieted by cords or biudages wrapped around it. Compare MonilLIFOKM.

STRĂP, the ligule of a ray-tloret in Compositx.

STRĂP-SHĀPED, broad, flat, and linear, like a belt; ligulate.

STRĂTÍFÍCĀTION, the thickening of a cell-wall hy the deposition of successive layers of formed material; also the arraugement of the layers so deposited.

STRĂT'ǏFIED THǍL'LǓS, a thallus in lichens in which the gonidia or algal cells are disposed in one or more layers.

STRÁA'TŌSE, in distinet layers or struti.

STRAW, the stems of varions edib]e grains, as whent and onts, especially af ter being threslied. Extended also to the laublm of peis, beans, etc.

STREAK (Hol't.), a long n:Irrow stripe.

STRĒAM'ǏNG OF PRŌ'TŌPLĂડ̦M, see Rotation.

STR $\overline{\mathbf{I}}^{\prime} \dot{\mathbf{A}}$ (pl. Strī' $\left.\bar{æ}\right)$, a straight and very narrow mark ol groove.

STRI'ĀTE, marked with parallel strix. Compare Surcate, Rivelose, Acicuiated, aud LINEA'TE.

STRĬCT, straight or upriglit; har. ing branches close together aud ereet: opposed to Lax. Ditfers from Fastigiate in being applied chietly to herbs and shrubs insteal of trees and in not necessirily having a pointed top.

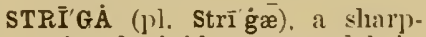
poiuted, rigicl, appressed bristle or hair-like scale.

STRǏG'ǏLōSE, minutely strigose.

STRĬGŌSE', covered with strigze. Formerly regarled as synonymons with Hispid.

STRIKE (Hort.), to take root, as a cutting.

STRINNG, any fibre; strand.

STRI'ŌLĀTE, diminutive of Striate, having very tine strixe.

STRIPED, lıaviug longitudiual lines of color, broader than Streaked and narrower than Bauled; having "longitudinal colored marks of any chameter.

STRŎBǏL ÁÁCEOǓs, cone-bearing; cone-like; pertinining to cones. STRǑB'ǏLE, see CONE. STRÓBǏLIF'ĚROUS, coniferous. 
STRŌBǏL'ǏFôRM, cone-shaped. STRŌBI'LǓS, see CONE.

STRŌ'MA் (pl. Strō'màtà), a mass in which another object is embedled, as a protein graunle which contains a crystal or starch - grain. Especially, a compact mass of mycelium upon or within which spores or sporangia are borne-applied mainly to tissue in which perithecia are embedded. Compare Hruenium.

STRŌ'MȦTOID, having the nature or appearance of a stroma.

STRŌMȦTOǏS, bearing or producing stromata.

STRŎMBŪLǏF'ẼROǓS, benring spirally twisted pods (strombi).

STRǑMBÜ'LIFFôRM, twisted in iL spiral, like the pods of alfalfa; cochleate.

STRŎM'BǓS (pl. Strŏm'bī), a spirally coiled legume, like that of alfalfa, Medicugo sativa; coclilea.

STRŌ'PHE, an old ter'm for leafspiral.

STRŌ'PHÍOLLATE, furnished with a stropliole.

STRŌ'PHǏŌLE, See CARUNCLE.

STRŬC'TŨRAL BǑT'ÁNY, the study of the form and arrangement of the parts of plants, including morphology and histology; vegretable anatomy; phytotomy.

STRU'MÁ, a one-sided swelling or protuberance of any kind, as the one-sided enlargement (apophysis) at the base of the capsule in some mosses, or the pulvinus of a leaf or leatlet. The term is now seldom used except in mosses.

STRƯ'MǏFôRM, like a struma in appearance.

STRỤMŌSE', swollen upon one side like a goitre; bearing a struma.

STRƯ'MŨLŌSE, slight ty strumose. STUKFED, the sime as Solid, or the old term Firctate, but seldom applied except to stems haviug at tibrous or spongy centre. Used mainly in mushrooms.

STŬMP'-ROOTĚD, applied in vegetable gatrdening to the roots of certinin varieties of the radish, carrot, etc., which, instead of tapering gradually from the flesty edible portion to the slender tap-root, have the transition abrupt. The term is not applied to the roots of turnip beets, flat turnips, etc., but only to such as are more elongated.

STU'PÁ, a tuft of matted hairs resembling tow. (Obs.)

STU'PẼOŬS, see STUPosE.

STŨPŌSE', resembling tow; covered with natted hairs resembling tow; stupeous.

STȲLE, the slender part of a pislil supporting the stigma.

STȲLǏF'ẼROǓS, style-bearing.

STY'LIYFôRM, style-shaped.

STȲLŌGōNǏD'IUUM, see STYLOSPORE.

STȲ'LŌPŏD, see STYLOPODIUM.

STỸLŌPŌ'DǏŬM, the fleshy disk crowning the ovary in most Umbelliferæ, formed by the expanded bases of the two styles.

STYYLōSE', having the styles remarkably long, numerous, or persistent. (Rare.)

STY' LŌSPŌRE, a stallked spore, sometimes septate, produced in a pycuidium: stylogonidiums; pycnogonidium; pycnospore; pycnidiospore; clinospore. 
STȲLŌSTÉ' '́ŭÚM （pl. Stylōstē'giá), the peeuliar orbicular corons, called sentum or shield, which terminates the style in Stapelia and similar asclepiads.

STȲLŌSTÉ'MǑN, au epigynous stamen. (Raile.)

SUĀ $\overline{\mathbf{A}} \bar{E}^{\prime} 0 \overline{L E N T}$, sweet-scented.

suB-, a Latin prefix meaning under, beneatli, subordinate, or partially.

SǓBÁCŪTE', moderately acute.

ऽǓBA $\bar{A} \bar{E}^{\prime} R \check{A} A L$, situated just above the grouvd or substratum, but covered with fallen leaves, etc. as many rhizomes.

SŬBÁPĬC'ÜLĀTE, llaving a small or poorly detiued apiculus or point.

SǓBÄRBŌRĔS'ÇENT, somewhat tree-like.

SŬBÁX'ǏLLĀRY̆, situated beueath the axil.

SŬBCAULĚS'CENT, with the leafy stem so sliort as to be hardly noticenble, but rather more developed than in Acaulescent.

SŬBCĚS'PǏTŌSE, somewhat inclined to srow in bunches. See Cespitose.

SŬB'CLÁSS, a group of order's or colıorts next suborelinate to a class.

SǓBCŎNCĂT'ENĂTE, growing somewhat in chains-in short or imperfect rows or cliains.

SǓBCǑN'ǏCAL, slightly conical.

SǓBCŎNTǏN'ŪOǓS, rarely or imperfectly septate; seldom or slightly constricted.

SŬBCÔR'DĀTE, sliglitly cordate. SŬBCRE' NĀTE, slightly or obscurely crenate.

SŬBCŬL'TRĀTE, slightly cultrate.

SŬBDĚN'TĀTE, imperfectly or obscurely dentate. Compare DENTICULATE.

SŬBDĚNTICC'ÜLĀTE, obscurely denticulate: having small, imperfect margiual teeth.

SǓBĚFFŪSE', lıving slightly spreadiug branches or tilameuts.

SŬBĔNTİRE', only slightıty notclied or toothed.

SŬBĔPǏDẼR'MAL TǏS'SŪE, see HYYODEIRMA.

SÜ'BẼ R, see Cokk.

SŬBĒR̆̌CT', nearly elect.

SÜBĒ'RĒOǓS, SEe SUBE1RosE.

SÜ'BẼRIN, eork - substancenearly or quite the same as C'utiu. See C'okk.

SŨBÈRǏFǏCÁ'TION, see SUBERIZATION.

SÜBẼRĬZA'TION, conversion into cork; suberisation; suberificalion.

SǓBĒRŌSE', laving somewhat the appearance of being gnamed; slightly erose. Compale ERose.

SÜ'BẼRōSE, of the nature of cork; suherous.

SÜ'BẼROǓS, SCe SUBEROSE.

SŬBFĂM ǏLY̆, a group of genera subordiuate to a family.

SǓBFLĔX' ŪŌSE, slightly wavy.

SƯBG'ENǏC'ŪLĀTE, slightly beut. SǓBG'E'NǓs, a species, or group of species, having nearly the rank of gemus.

SŬBGLŌBŌSE', nearly glolose.

SŬBHȲME' $\bar{E}^{\prime} \mathbf{I U} M$, a layer of tissue next below the hymenium; hypothecium.

SŪBÍC'ŪLŬM, a term applied by M. C. Couke to the abuormally thickened portion of a leaf or stem hearing the cluster.cups in Ecidium. 
SŬBKǏNG'DOM, the bighest subdivision of a kingdom, as the phenogams and eryptogams among plants; series. Some recent botanists divide the vegetable kingdom into more than two subkingdous.

SŬBLẼNTǏC'ÜLAR, somewhat lens-shaped.

SǓBMÄR'GINAL, situated near the margin.

SŬBMẼRGED', see SUBMERSED.

SŬBMẼRSED', growing under water: submerged; demersed.

SŬBNĂS'ÇENT, originațing or growing beneath any object.

SǓBNŪDE', nearly destitute of hairs, leaves, or other covering.

SŬBǑBTŪsE', slightly obtuse.

SŬBÔRBIC'ŪLAR, nearly circular; subrotund. Compare SUBglobuse.

SŬBÔR'DẼR, a group of genera within an older. Compare TRIBE.

SUัBŌ'VATE, somewhat orate.

SŬBPĒDŨN'CŪLĀTE, having a very short peduncle; subsessile.

SǓBPĚT'ǏŌLAR, situated beneath the petiole, i.e., under (rithin) the base of the petiole, as the leaf-bud in sycamore. Com. pare SUBPETIOLATE.

SǓBPĔT'ǏŌLĀTE, having a very short petiole; subsessile. Compare SUBPETIOLAR.

SǓBRĀ'MÕSE, having very few branches; subsimple. Compare Rasose.

SǓBRÍG'ǏD, slightly rigid.

SŬBRŌTŬND', see SUBORBICULAR.

SƯBSĚR'RĀTE, sparsely or obscurely serrate. Compare Serrulate.

sǓBSĚS'SǏLE, nearly sessile; sub. petiolate or subpedunculate.
SŬBSHRŬB'BY̆, see FRUTESCENT. SǓBSĬD'ĪĀRY C̆ĽLL, see ACCESSORY CELL.

SŬBSǏM'PLE, with very few sub. divisions or branches.

SŬBSPE்'CIẼS, a variety nearly equal in rank to a species; a marked variety.

SǓB'STǏTŪTE FI'BRE, a term applied by Sanio to a prosenchymatous cell larger in diameter than a librifurm cell and without its attenuated ends. Not in general use.

SŬBSTŌMĂT'ĪC CHĀM'BẼR, see STOMATIC CHAMBER.

SŬBSTRA'TŌSE, in somewhat indistinct or irregular layers or strata.

SŬBTĚND', to embrace in its axil. A flower is subtended by a bract when there is a bract situated beneath it. Nearly all buds are subtended by leares.

SŬBTẼRẼTE', somewhat terete.

SŬBTĔRRA'NEAN, beneath the surfice of the ground; hypo. gean.

SŬB'TRĪBE, a group of genera subordinate to a tribe.

SÛ'BÛLĀTE, uarrow, and tapering to a sharp rigid point, as the leaves of juniper; awl. shaped.

SŪBŪLIF'ẼRoǓs, furnished with awl-slıaped spines. (Obs.)

SŨ'BŨLǏFôRM (obs.), see SüBULATE.

SUัBUัM'BĚLLĀTE, s o m e $\mathrm{w} h \mathrm{~h}$ t umbelliform, as the flowercluster of the apple.

SŬBVẢR I'ẼTY̌, a subordiuate variety; a variety within a variety.

SǓBVĔN'TRǏCŌSE, somewhat ventricose or inflated. 
SŬBVẼRTİÇ'ǏLLĀTE, verticillate; in imperfect or irregular whorls.

SŬCÇĒDA' $\bar{A}^{\prime} \mathbf{E} \bar{U} M$, a substitute.

SŬCÇES'SǏVE WHÔRL, a whorl the members of which do not all originate at the same time, but in suecession, either in regular order or otherwise. Compare SIMUL'LANOUS TV HOIL.

SŬCÇǏF'ẼROǓs, producing or conveying sap.

sưcĊISE', 1erminating abruptly, as though eut sharply off. Compare Trencate and PreMORSE.

SŬC'CōSE, see SucculeñT.

sǔc'cüBoŭs, having the base or lower edge of each leaf overlapping the apex of the preceding leaf, as in Jungermannia. Compare Ixcubous.

SŬC'CŪLENT, soft, and fleshy or juicy; pulpy.

SỨCK'ẼR, (1) a sprout or shoot, especially from the root or lower pairt of the stem (surculus); (2) sometimes applied to aerial roots or other holdfasts; (3) a baustorium.

SǓCK'ẼR, v. i., to put forth shoots from the lower part of the stem, as Indian corn.

SŪDORǏF'ǏC, causing perspiration.

SǓFFRỤTĚS'ÇENT, s 1 i g h t $1 \mathrm{y}$ shrubby.

SǓF'FRUTKXX, a plant with a woody base and herbaceous stems or brauches. Applied mainly to perennials. See UNDERSHRUB.

SŬFFRU్'TǏCŌSE, either suffrrutescent or like an undershrub.

SǓFFRỤTIC'ŪLŌSE, slightly fruticulose, as some licheus.
SǓL'CĀTE, having one or more large, straight, longitudinal grooves or chanuels, as the stem of parsnip. Compare Rivose and S'TRIATE.

SǓL'CǓS (pl. Sŭl'çī), a lougitudinal groove or furrow; sulcation. Compare Stria.

SŬLPHŪ'RĒOŬs, sulphul-yellow -paler than Luteus. About the same as Flavus.

SŬM'MẼR-SPŌRE, ally spore or gonidium which retains its vitality but a short time, and is inteuded for the propagation of the plant during the summer, as the uredospores of wheat-rust. Compare REsTING-SPORE.

SUPER- (or SUPRA-), a prefix from the Latin, meaning ahove in position or degree.

SŪPẼRĂX'ǏLLĀRY̆, s i t u a t e d above the axil, justead of within it, as the accessory buds sometimes seen in the butteruut; supraxillary; superfoliaceous: suprafoliaceous.

SÜPẼRCRĔS'ÇENCE, a parasite. (kalve.)

SÜPẼRCRĔS'CENT, $g$ lo $\mathrm{W}$ in g above auother part or body; especially, growing upou some other growing thing. (Rare.)

SŪPẼRDẼCŎMPOŨND', see SUPRADECOMPOUND.

SÜPẼRFĔCŬNDÁ'TION, the conjugation of more than two gametes. Compare SUPEIFETATION.

SÜPẼRFẼT $\bar{A}^{\prime} T I O N$, the fertilization of an ovary by two or more kiuds of pollen, so that its seeds are not all alike. Compare SUPERFECUNDATION. SŪPẼRFŌLI $\bar{A}^{\prime} C$ CEOŬS, sE S'TPERAXILLATIY.

SÜPE'RIOR, said of a radicle when it points towards the 
apex of the fruit (ascending); said of the ovary when the calyx is free from it; satil of the calyx when adherent to the ovily and thus, with the other floral organs, situated upon its summit; applied to the upper side of a lateral Hower, the sille next the axis: the vexillum, for example, is the superior petal of a papilionaceous corolla.

SÜPẼRNA'TANT, floating on the surfice.

SŪPẼRNŪ'MẼRĀRY̌ BUDS, see ACCESSORY BuDs.

SÜ'PẼRPĂRȦSITTE, a parasite of a parasite; hyperparasite.

SÜ'PẼR - PLĂNT, a plant which grows upon auother plant, either as an epiphyte or a parisite.

SŪPẼRPŌS̆ÍTION, s i t u a t i o n above some other organ; or, when referring to parts of the Hower, the non-alteration of the members of contiguous circles, the corresponding parts being opposite instead of alteruate; anteposition. See Direct and Inverted SuperPOSITION.

SŪPẼRTŪBẼRÁ'TION, an abnormal production of secondary tubers directly unon those prodiced in the ortinary manner.

SŪPẼRVōLŨTE', plaited and the platits convolute, as the corolla of morning.glory.

SÜPINE', lying flat, with face upward; dorsicumbent-opposed to Prone. Compare ResuPINATE.

SǓPPŌRT'ǏNG PLANT, a plant upon or within which another grows, either as a parasite or in epiphyte. See Host.

SǓPPRĚS'SION, the eutire non- development of a part; com. plete abortion; obliteration.

SUPRA-, see SUPER-.

SŪPRÁĂX'ǏLLĀ $\breve{Y}$, see SUPERAXILLAliY.

SÜPRÁDĒCŌM'POUND, three or more times compounded, or very much subdivided in any manner. A piunate leaf, like that of walnut, is compound; a bipinnate leaf, like that of loney locust, is decompound; a tripinnate leaf, as in many acacias, is suprudecompound.

SŪPRȦFOัLǏ $\bar{A}^{\prime} C$ EOŬS, see SUPERAXILLATX.

SŪPRẼME', situated at the highest point.

SÛRCŪLI'G'ẼROǓs, see SURCU. LOSE.

SÛR'CŪLŌSE, having suckers (surculi).

SÛR CÛLǓS (pl. Sûr'cūlī), a spront or shoot from the ground or base of the stem; sucker.

SÛRCǓR'RENT, lıving winged expansions from the base of the leaf prolonged up the stem. Compare Decurrent.

SǓSPĚND'ED, said of seeds or ovules which are attached to the top or sides of the ovary and hang downward; pendulous; inverted. Co m pare ERECT and AscendiNG.

SŬSPĚN'SOR, (1) a single or multiple row of cells which is the first development of the fertilized oösphere in phenograms, and at the extremity of which the embryo is developed: it appears upon the embryo as a continuation of the ralicle; proembryo; (2) the cell which supports the conjugating cell in IIncorini.

SU'TŪRE, a liue of junction or dehiscence. 
SWARM, « unmber of spores or unicellular individuals of common origin which remain near togethe' without being united iil iny way.

SWẠRM-ÇELL, see ZoösPoRE.

SWẠRM'ǏNG, moving about by means of cilia-said of zoö. spores. Chietly used when unay are together. See SwrmIING.

SWA RM-SPŌRE, see ZoÖSPORE.

SWIM'MING, moving unattached within a liquid in any definite mawner. Compare NATANT. The swimulug of zoöspores when massed, however, is iermed Siwarming.

SWŌRD' - SHÄPED, see ENSIFOIR, SY̌€HNŌCÄR'POǓS, see POLYCARPIC.

SỸ $\overline{\mathbf{O}}^{\prime} \mathbf{N}$ ĬŬM, see STCONus.

$\mathbf{8} \overline{\mathbf{Y}} \mathbf{C} \bar{O}^{\prime} \mathbf{N}$ Ŭs, the fruit (hy panthium) of the fig, consistiug of an expauded fleshy receptacle enclosing the flowers.

SY̌L $\mathbf{L}^{\prime} \mathbf{V A}$ (pl. Sy̆l'væ), the trees of a country or region, or a work describing theul.

SYL'VAN, pertaining 10 woods.

SY̌LVĔSTRǏNE, glowing in woods.

SY̌MBĪ̄̄'SIS, the coexistence in more or less mutual interdependence of two different organisms, as the fungus and alga which constitute a lichen; mutualism; mutual parasitism; commensalism; consortism. With some authors Commensalism implies an association less necessary or mutually helpful thau Symbiosis.

SY̌MMĔT'RǏCAL, (1) llaving sepals, petils, aud stameus of the same number, or multiples of one another; (2) divisible in one or more directions into halves, which are similar to, or the reflections of, each other. See MonosyamerriCAL and Ponysymetrical.

SY̌MPĚT'ALOǓS, S世C GAMOPETALoUs. Also formerly used for a partial union of the petals with monaclelphous sta. mens, as in Malvacere.

SY̌MPHY̌ ĂN'THẼROŬS, see SYNANTHEROUS.

SY̌MPHY̌CÄR'POǓS, having the fruits confluent, as the disks of the apothecia in certnin lichens.

SY̌MPHY̌L'LOǓS, see GAMOPHYLLOUS.

SY̌MPHY̌ōǴĒĚT'ǏC, formed of parts which liave become grown together or united.

SY̌MPHY̌ŌSTĔM'ŌNOǓS, monadelphous, synantherous, or with the stamens united in any other manner: symphystemouous.

SY̌M'PHY̌SǏS, a union of parts usually distinct; cohesion or adhesion.

SY̌MPHY̌STĔM'ŌNOǓS, see SXMPHYOSTEMONOUS.

SY̌M'PŌDE, see SYMPODIUM.

SY̌MPŌ'D ĬAL D $\bar{I} € H ठ T^{\prime} \overline{0} M \breve{Y}$, where one branch of each successive bifurcation contiu. ues to develop and the other remains subordinate. See Scorpioid and Bostrychold DiCHO'TOMY.

SY̌MPŌDIŬM, a stem which cousists of a series of secondary stems or axes which have arisen as branches one from another, as in the tomato: psendaxis; false axis.

SY̌N $\check{A} C^{\prime} M \check{Y}$, haviug the stamens and pistils ripern at the same time, neither protandrous nor protogynous: synanthesis: opposed to Heteracmy. 
SY̌NAN'GY̌ $\mathbf{M}$, the peculiar boatslaped sorus of certain ferus of the order Marattiacere.

SY̌NĂN'THẼROǓS, having the stamens united by their anthers, as in Compositæ; symphyantherous; syugenesious.

SY̌NĂNTHE'SǏS, see SYNACMY.

SY̌NÁN'THOǓS, (1) having tlie flower's expand at the same time as the leaves. Compare Proteranthous and HysterANTHous. (2) Exhibiting synantliy.

SY̌NĂN'THY̌, the abuormal coalescence of two or more flower's.

SY̌N'CÄRP, SEe AGGREGATE FIRUIT.

SY̌NCÄR'PǏ $M$, see AGGREGATE FIrU1T.

SY̌NCÄR'POǓS, formed of distiuct aggregated carpels.

SY̌NCǑTY̌LĽD'ÓNOǓS, having coherent cotyledons.

SY̌NÇY'TǏ nuclei without cell-walls.

SYYNE'DRAL, growing upon the angle of a stem.

SY̌NE'MA, that part of the column in orchids which represents the united filanients of the stamens.

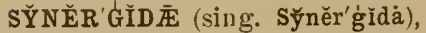
two cells (or nuclei) in the upper end of the embryo-sac, which together with the oösphere form the egg-apparatus.

SYYN'ẼRĞY the simultaneous action of several organs.

SY̌NG'ENE'SIOǓS, see SYNANTHEROUS.

SY̌NOCC'RĒATE, said of stipules when united around the stem so as to form an ocrea or slieath.

SY̌NOE'ÇOǓS, (1) having male and female flowers in the same head, as in some Composita; (2) having antheridia and ar- chegonia in the same receptacle in mosses.

SY̌N'ŌNY̌M, a superseded plantname.

SY̌NǑPH'Y̌TYY, the colesiun of two or more embryos in a seed. (11. C. Cooke.)

SY̌NǑP'SİS (pl. Sy̆nǒp'sēș), a condensed description of a genus, species, or other gromp.

SY̌NPĚT'ALOǓS, sce GAנOPETALOUS.

SY̌NSĚP'ALOǓS, see GAオOSEPALOUS.

SY̌NTĂG'MA் (pl. Sy̆ntăg'màtà), a name applied by Pfeffer to all bodies composed of tigmata, which see.

SY' $\bar{Y}^{\prime} \mathbf{P H O N}$, see SIPHoN.

SY̌S'TĔM, (1) an arrangement of natural objects according to some rule; (2) the sum of the parts of an organism which are of the same morpholngical nature or perform a similar function, as the fibroviscular or intercellular system.

SY̌S'TĔM, ÄRTǏFI'ÇIAL, see ARTIFICIAL SYSTEM.

SY̌STĚMĂT'ÍC BǑT'A $\dot{A}$ Y̌, the part of botany which treats of the description, naming, and classification of plants. See VEGETABle Taxonomy and PhyTOGRAPHY.

SY̌S'TĚM, NĂT'ŪRAL, see NATURAL SYSTEM.

SY̌S TRŌPHE, the massing of the chlorophyll bodies of a cell under intense light. Compare Apostrophe and Epistrophe.

TẢBĚS'ÇENT, wasting or shrivelling.

TÁB'ŨLAR, flattened horizontillly.

TĂG'MÀ (pl. Tăg'màtà), a name giveu by Pfeffer to any aggre- 
gate of molecules, including pleon, micella, and micellir aggregate. See these terms.

TÃIL, any long, flexible, terminal appevdage. as the persistent style on the seed of Clematis.

TÁIL'-POINTÉD, tipped with a long, flexible acumination.

TĂN'GLE, see SkEIN.

TANK'ARD-SHĀPED, thickened, about twice as long as broad, gradually enlarged downward, then suddenly contriacted or terminated, as the root of some varieties of the turnip and radish. Compare STuMPIROOTED.

TÁ'PẼR POINTĚD, see ACUMINATE.

TÁPE'TŬM, (1) a layer of cells, just outside the archesporium, lining the cavity of an anther or a sporangium. It usually becomes disorganized and absorbed before the liberation of the spores or pollen-grains; (2) ir similar layer of cells surrounding the embryo-sac.

TÄ'-ROOT, a main root which runs directly downward.

TÄRTÁ'RẼOŬS, laving the surface rough and crumbly, as that of many lichens. (Obs.)

TÁS'SEL, the popular name for the staminate inflorescence or terminal compound spike of Indian corn. Som et imes called Spindle.

TAW'NY̌, see Fulrous.

TĂXǑL'ōGÝ, see TAXoNomY.

TĂX̌N'0̄MY̌, see Vegetable TaXoNomY.

TE AR, a drop of gum or resin as it has issued from the plant.

TÉ AR'-SHĀPED, of the shape of an apple-seed-the same as pear-shaped except that the sides are not contracted.
TEETH, see TоOTH.

TĔG'MĚN, the invermost seedcoat; endopleura. Called Secundive in the ovule.

TĔGMĚN'TŬM (pl. Těgměn'tá), an old term for Bucl-scale.

TEG'ÜMENT, SE INTEGUMLENT.

TÉ'LȦ CǑNTĔX'TÁ, see FELTED Tissue.

TÉLEU'TŌSPŌRE, a thick-walled, usually compound, goniclium produced by the Uredinex or rust-fungi late in the season and which serves to reproduce the fungus the next yenr; brand-spore; pseudospore.

TĚN'DRILL, a slender appendage which serves for support by coiling around some other object. It may be morphologically a leaf, leatlet, stipule, or stem.

TĔN'TÁCLE, one of the sensitive glanclular hairs on the leaf of Drosera.

TĚNŨ ǏFō'LǏOǓS, having thin, narrow leaves.

TĚP'AL, one of the parts of a perianth, either sepal or petal. (Rare.)

TĚRÁTÓL'óğy, the study of abnormal structures; morphology as applied to monstrous growths. Not applied to malformations due to disease.

TẼI'Ç̌NE, a third coat to the ovule, counting from the outside-not in constint and defivite structure.

TÉRETTE', cylindrical, ol somewhat tapering.

TẼRGĔM'INAL, see TERGEMYNATE.

TẼRGEMM'ÍNĀTE, having three pairs of leaflets or other organs attached, by secondary petioles or otherwise, to the apex of a common sujport. Compare 
Ternate, Ternate-Pinnate, and TriJugate.

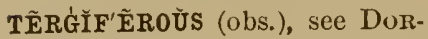
SIFEROUS.

TẼRGY̌SPẼR'MOǓS, bearing reproductive bodies upon the back, as the leaves of ferus. (Obs.)

TẼR'GŬM (obs.), see DorsUM.

TẼR'MǏNAL, attached to or pertaining to the extremity or apex.

TẼR MǏNAL BŬD, a bud at the extremity of a branch or stem. Compare Lateral Bod.

TẼ R'NÁR Y , consisting of three. Compare Ternate.

TẼ $R^{\prime} N \bar{A} T E$, growing in threes, as the leatlets in clover.

TẼR'NĀTELY̌ TRĪFō'L ǏŌLĀTE, having three leaflets attached at one point, as in clover. Compare Trifollolate.

TẼR'NĀTE - PǏN'NĀTE, having three secondary petioles, each bearing pinnate leaflets, attached to the apex of a commou petiole. If each secoudary petiole bears but a single pair of leatlets the leaf is called Tergeminate.

TẼRPINN'NĀTE, see TRIPINNATE.

TĚRRĚS'TRIAL, growing on lind, not aquatic; growing on the gromd, not on trees.

TĚS'SĚLLĀTĚD, haviug square spots, arranged like those on a chess-board.

TĚS'TA, the outer seed-coat, cilled primine, in the ovule; spermoderm.

TÉ STA $\bar{A}^{\prime} C E O U$ U, browvish yellow, like unglazed earthen-ware.

TĚSTǏC'ŨLĀTE, oval and solid, like the tuberous roots of certain orchids.

TĚST'ŨLE (olds.), see FrUSTULE.
TETRA-, in Greels compounds, four.

TĚTRẢCĂM'ÁROǓS (obs.), about the same as Tetracoccous. See Camara.

TĚTRẢCÄR'PĔLLĀRY̆, of four carpels.

TĚTRẢ€HE' NǏ sisting of four achenium-like carpels, as iu Labiatæ.

TĚTRA் CHǑT'ŌMOǓs, dividing at the end into four branches.

TĔTRÁCǑC'COǓS, of four cocci.

TĚTRA்ÇÝC'L ǏC, composed of four whorls, as a flower having calyx, corolla, and stamens each of one whorl and a single (simple or compound) pistil.

TÉT'RĂD, a group of four pollengrains.

TĚTRẢDY̌N'ȦMOǓs, having six stamens, four of which are longer than the other two. Compare Didznamous.

TĚTRÁFŌ'LǏOǓS, having bijugate leaves, i.c., having leaves with two pairs of leaflets.

TĒTRĂG'D̄NAL, prismatic and quadrangular ; four-angled; tetragonous. Compare TETRAQUETROUS.

TĚTRẢGōNǏD' ǏŬM ( 1 l. Tětràgōnǐd'ia), sce TE'Traspore.

TËTRĂG'ŌNOǓs, see TETRAGONAL.

TĒTRĂG'Y̌YNOǓS, having four pistils or styles.

TÊTRĂM'ẼROǓS, having four parts or the parts in fours. Applied mainly to flowers which have four members in each set or whorl of orgaus. Compare Dimerous, TrimERous, etc.

TẼTRĂN'DROǓS, having four stamens. 
TĚTRÄPĚT'ALOŬS, having four petuls.

TÉTRĂPH'Y̌LLOǓS, four-leaved. Often used for 'Tetrasepalous.

TẼTRĂQ'UETTROǓS, having four salient angles. Compare TETRAGONAL.

TE'TRÄREH, a term applied to a tibrovascular cyliucler which represents four tibrovascular bundles.

TELTRȦSĚP'ALOǓS, of four sepals. See Tetrapirllous.

TĚTRẢSPÈR'MOǓS, four-seeded.

TĚTRÁSPŌRĂN'GIŨ M, a sporangium (unicellular) contaiuiug tetrasspores.

TÉT'RÄSPŌRE, a gonidium or asexually produced spore in Floridere. So called from being often produced four together in a mother-cell ; tetragonidium.

TẼTRĂS'TǏ€HOǓS, in four vertical rows upou a stem.

THĂLA்MǏFLō'RAL, having the stameus inserted upon the receptacle. Compare CoroluFLORAL and CALTCIFLORAL.

THĂLẢMÍFL $\bar{O}^{\prime}$ ROUัS, see THALAMIFLORAL.

THĂL'A்MǓS (pl. Thăl'àm̄̄), the receptacle of a flower.

THA்LĂS'SŌPHȲTE, a sea-alga. (Rare.)

THĂL'LŌĞẼN, see 'THALLOP IY'TE.

THĂL'LOID, having the form or nature of a thallus. Compare Foliose and Frondose.

THĂLLOI'DAL, see TIIALLOID.

THĂL'LŌME, see 'THALLUs. Compare Caulome.

THĂL'LŌPHȲTE, a plant whose vegetative body is a thallus, as a lichen, fungus, or alga; cellular cryptogam; thallogen. Compare Corsophrte.

THĂL'LǓS (pl. Thăl'lī), a vegeta- tive body without true leaf or stem, as that of most crypto. gams; thallome.

THĂL'LǓS PLẢCō' DĒS (ōos.), see Foliaceots 'THallus.

THĂL'LŬS THĂMNŌ'DĒS (obs.), see Fliuticose Thallus.

TH $\overline{\mathbf{E}}^{\prime} \mathbf{C A}$ (pl. Thé'çæ), a sporangium or anther-cell. (Rare.) Fommerly in general use for ascus, and still used by some writers for the sporangium or capsule of mosses.

THE' $\bar{E}^{\prime} \dot{A} \mathbf{P H} \overline{0} \mathrm{RE}$ (obs.), see GrNo. PIIORE.

THE'CẢSPŌRE, see AscosPorE.

THĒÇǏF'ẼROǓs, bearing asci or other thece; thecigerous. (Rare.)

THĒC̣ÍG'ẼROǓS, see THECIF. Elious.

THẼRMŎT'RŌPǏSM, the property or phenomenon of movement under the influence of heat or cold. Curvature toward a source of licat is callerl positice thermotropism; curvature in the opposite direction, negative themotropism.

THǏCK'ENǏNG LĀY'ẼR, au apparent layer of cellulose deposited upon the inner surface of a cell-wall. It appears as a layer only because of its power of absorbing water in a different degree from the remainder of the cell-wall.

THǏCK'ENING RING, the cambium-ring, or auy other ring or layer of thickeving or meristematic tissue.

THÔRN, a degenerated, sharppointed branch, either simple, as in the thorn-apple, or branchel, as in the honeylocust. Sometimes applied to other large, sharp, rigid processes. Compare SPINE and Plixicke. 
THRĔAD-SHĀPED, see FILIF() KM.

THREE - AN GLED, see TRIGONOUS.

THREE-CLĚFT, see TRIFID.

THREE - LEA VED, see TrIFOIIATE.

THREE-LŌBED, having three lobes or segments.

THREE-NẼRVED, having three principal veins proceeding from the base of the leaf in monocotyledons. A p plie l mainly in the Horal envelopes of grasses; trinervate; triplenerved.

THREE.PÄRT'ĚD, divided into three parts, or having the parts in threes: a three-parted leaf lias three lobes or leaflets; a three-parted flower has three petals.

THREE-RĂNKED, in three verticul rows upon a stem; trifarious; tristichous.

THREE-VĂLVED, having three valves or dehiscent portions of a pericarp; trivalvular.

THRŌAT, see FAUX.

THRUัM, an old term for stamen.

THRŬ M-EȲED, a tlorist's term for flowers having long, couspicuous stamens aud a short style. Compare PIN-EYED.

THY̌LI, see TyLosIs.

THȲ'LŌSE, see TYLosis.

THỸRSE, a compact panicle, lilse that of the lilic and grape.

THỸ R'SOID, thyrse-like.

THỲR'SŬS (pl. Thỹr'sī), see THYRSE.

TIGE [pro, tēzh], stem. (Rare.) TĬGĔLLE', see 'TigeLLuM.

TǏGĔL'LŬM (pl, Tĭgěl'lä), see CAULICLE.

TǏL'LẼR, n., a sucker or branch from the base of the stem. (Obs.)

TIIL'LẼR, v. i., to put forth new shoots from the root or around the base of the original stalk, as wheat; stool. Applied mainly to the smaller cultivated plants of the grass family. Compare Sucker.

TǏL'LōW (obs.), see TILLER.

TIIM'BẼR-LINE, the upper limit of arborescent vegetation upon high mountaius, as determiued by coll.

TǏNCTŌ'RĬoŬs, capable of serving as a lye.

TǏs'SūE, a greneral term for all the material of which plants and animals are formed; particularly, a collection of cells of similar character, as vegetable tissue, epidermal tissue, fibrovascular tissue.

TǏs'SŪE-CÔRD, see CENTRAL CORD.

TO' $\overline{0}^{\prime} \mathrm{ME}$ NTŌSE, covered with mitted woolly hairs.

TŌMĚN'TOǓS, see ToMENTOSE.

TŌMĚN'TŪLŌSE, slightly tomentose.

TŌMĚN'TŬM, matted woolly hairs.

TōMǏP'ẢROǓs, producing spores by division. (M. C. Cooke.) See Fissiparous.

TONGUE, see LIGULE.

TỎNGUE-SHĀPED, long, thickened, nearly flut, and rounded at the end; lingulate; linguiform; linguæform.

TŌN'ŌPLĂST, a term sometimes applied to a vacurole-wall. See VACUOLE.

Tо̄oTH, any small, pointed, marginal lobe, especially of a leaf.

TOOTHED, see DENTATE.

T00TH'LĔT, a small or secondary tooth; deuticulation. 
TOOTH'LETE, see DENTICU. LATE.

Tð̆'Ǐ́cAL, local; confiued to a limited area.

TǑP'-SHĀPED, see TURBINATE.

TŌRN, with marginal incisions deep and irregular. (Rare.) Compare JAGGED, LACINIATE, and INCISED.

TōRōsE', cylindrical, and swolleu at intervals. See Moniliform.

TÔR'SION, the state of being twisted spirally.

TôR'TŪoǓs, bending or turning in various directions.

TǑR' ŪLŌSE, somewhat torose.

Tó' $\mathbf{R}$ ŬS, (1) the extremity of the stem, upon which the floral organs are situated, usually termed Receptacle; thalamus; (2) a thickened centre in the closing membrane of a bordered pit.

TRẢBĚC'ŪLẢ (pl. Trảběc'ūlæ), one of the transverse processes upon the inuer face of the teeth of the peristome in mosses; a projection from the wall across a cavity, as the bands of tissue crossing the sporangia of Isoetes or the cellular filaments across the space surrounding the fibrovascular bundles in Selaginella; any cross-bar, as one of the connecting threads in a reticulum.

TRẢBĚC'ÜLAR, having or pertaining to trabecula; trabeculate.

TRẢBĔC'ŪLAR VĚS'ŠLL, one -whose cavity is crossed by ligneous threads or bands.

TRÄBĚC'ÜLĀTE, having trabeculæ; trabecular.

TRĀ' SPIRAL VESSEl.

TRĀ'€HĒĬD (pl. Trā'chēìds or Trachē'idēs), a woody vessel composed of a single cell. Applied mainly to those having bordered pits.

TRĀIL'ÎNG, elongated, and prostrate upon the ground, but not rooting. The same as Running, except that the plant may be shorter, or may rise at first from a woody or otherwise self-supporting base. Compare Crenping.

TRÄJĚC'TǏLE (obs.), see DISTRACTILE.

$\mathbf{T} \mathbf{R} \overline{\mathbf{A}}^{\prime} \mathbf{M} \dot{\mathbf{A}}$, the substance of the same character, as the pileus in the gills of agaries. It supports the subbymeneal layer.

TRĂNSFŎRMA' 'TION. This term is used in botany mainly in the same sense as Metamorphosis. A petal, for example, is called a transformed or inetamorphosed leaf, not because the particular petal under consid eration has ever been a foliageleaf, but becanse it is a leaf in a special or unusual condition. The word Transformation is also used for the changes in a particular organ during its development or growth.

TRANSMŨT $\bar{A}^{\prime}$ TION, see MIETABOLISM.

TRĂNSPÍRA'TION, the normal escape of Huids from within the plant; exhalation. It includes not only the escape of moisture, botls in the form of vapor aud, as occasionally occurs, in the liquicl state, but also the gaseous products of respiration. The trauspiration of moisture is sometimes, but unnecessarily, termed Perspiration.

TRĂNSVẼRSE' $€$ EHō'RǏSǏs, when two or more organs in place of one stand one above or within another; vertical chorisis. 
Compare Collateial ChoRISIS.

TRĂNSVẼRSE' ĠĒŎT'RŌPǏsM, see DiAgeotropisy.

TRĂNSVẼRSE' HĒĽǑT'RōPǏșM, see DIAHELIOTROHISM,

TRẢPE'ZǏFôRM, unsymmetrically four-sided, like a trapezium; trapezoid.

TRĂP' EZOID, see 'TrAPEZIFORM.

TRĂP'ẼZOID, n., a body having the form of a trapezium. (Rare.)

TREE, a woody plant capable of growiug in the given locality at least tweuty feet in height, with a single self-supporting stem. If the top is unusually broad the lheight may be somewhat less. The standard is arbitrury and varies considerably atcording to circum. stances. Compare simer.

TRĔM'ĚLLOID, gelatiuous, like the Tremellinere.

TRI-, three.

TRİADEL'PHOŬS, having the filanents in three sets.

TRĨĂN'DRǏAN, see TrIANDHOUS.

TRİĂN'DROǓS, having three stamens.

TRĬANN'GŬLAR, having three sicles or augles;-applied either to flat bodies like leaves, or to columuar bodies like stems. Compare 'ТrigoNot's.

TRĪĀ N'THOǓs, three-flowered.

TRI'ÄREH, a fibrovascular cyliuder which has three ligueous rays, and thus represents three fibrovascular buudles.

TRIBE, a group of genera subordinate to an order or suborder. Similar groups are in some cases called families.

TRĪCÄR'PĚLLĀRY̌, haviug three carpels in a flower or pistil; trigynous.

TRİCAR'POŬS, containing three ovaries or fruits.

TRİÇĚPH'ÁLOǓS, thrce-headed.

TRİEH'ŌBLĂST, an interual hair, like those which project into the intercellular spaces of some water-lilies.

TRǏEH'ÖĞYNE, a sleuder prolongation of the carpogonium in Floridex which receires upon its apex the antherozoids in fertilization.

TRǏєHō'Mả (pl. Trǐchōmmátả), a term sometimes ipplied to filaments of confervi aud some other algie, especially to the multicellular filaments in Nostoclinese.

TRǏ $€ H^{\prime} \overline{O M E}$, a plant-hair of any kind.

TRİ€H' $\mathbf{0} \mathbf{P H} \overline{\mathrm{R} E}$, the cell or cells immediately supporting a trichogyne.

TRǏєHŌSPŌRĂN'GIU ŬM, a sporanginm which is morphologically a hair. Formerly also applied to the plurilocular sporangia of Phreosporex.

TRİєHŏT'ŌMOǓs, dividing at the end into three brauches; threeforked; trifurcate.

TRİCóC'COǓs, of three cocci. TRI'COLOR, of three colors. TRĪCǑs TĀTE, three-ribbed.

TRICŬS'PĨD, three-pointed; tricuspiclate.

TRĪCÚS'PǏDĀTE, see TRICESPID. TRĪDĚN'TĀTE, three-toothed.

TRİEN'NǏAL, a plant which fruits the third year, then dies. Few plants, if any, are strictly of this character. Compare $\mathrm{Br}$ FNNIAL.

TRIFĀ'RĪoǓs, in three rows, or pointing in three directions; especially, in three vertical 
rows upon a stem; threerauked; tristichous. Compare Triserial and Mul'tifaRIOUS.

TRI'FÍD, three-eleft; divided into three parts about half-way to the base.

TRIFLŌ'ROǓS, three-flowered.

TRĪFO'LİATE, strictly, threeleared, but often incorrectly applied to leaves which have three leatiets, as those of clover. Compare 'T'riphrLLOC's.

TRÎFōLǏ̄̄LĀTE, having three leatlets. Usually but incorrectly called Trifoliate.

TRĪFÛR'CĀTE, see TrichotoMot's.

TRĬG'ÁMOŬs, having staminate, pistillate, and perfect flowers in the same head in Compositæ, being one of the polygamous contitions.

TRİGĔM'ǏNOǓS, see TERGEMINATE and TriJUGate.

TRĬG'ŌNAI, see Trigoxous.

TRĬG'0̄NOǓS, prismatic, and three-angled, is the stems of sedges; trigonal. Compare Triouetrots.

TRĬG'Y̌NOŬS, lıving three pistils or styles; tricarpellary.

TRIJJ'ÜGĀTE, having three pairs of leaflets arringed in any manner upon a leaf, especially along a common petiole; trijugous. Compare Tergemixate.

TRǏJ'ŨGOǓs, see TRIJCGATE.

TRILĂT'ẼRAL, three-sided. See TRIGONOTS.

TRILŌ'BĀTE, three-lobed.

TRÍLOC'ÜLAR, three-celled: applied to pericarps.

TRI'MĚROǓS, having the parts in threes: applied to flowers having calyx, petals, and stamens each three or a multiple of three. Sometimes written 3-merous.

TRĪMÔR'PHǏc, see TrumoRPHOUS.

TRĪMôR'PHOǓs, having three kinds of flowers in the same species, differing in the relative lengths of their stamens and pistils; heterogronous trimorphous. Compare DiuorpHoUs. See Heterogoxous.

TRÎNÊRV'ĀTE, see THREENERTED.

TRI'NÈRVED, see THREE NERVED.

TRĪNŌD'AL, having tliree nodes.

TRĪĒ'ÇIOǓs, having a polygamous condition in which there are staminate, pistillate, and perfeet flowers, each on different sets of plants.

TRĨOI COŬS, see Tricecious.

TRĪŌVŪLĀTE, containing three ovules.

TRI'PÄRTĔD, see TRIPARTITE. Compare TilReE-PARTED.

TRÍP'ARTİTE, divided into three parts nearly to the base; threeparted.

TRĪPĚT'ALOǓS, of three petals.

TRǏPH'YLLOǓS, having three leares or leaf-like bodies in a whorl, or otherwise associated; -applied especially to a threeleared calyx or periantl.

TRIPIN'NĀTE, thrice pinuate, as a bipinnate leaf the leatlets of which (or some of them) are themselves pinnate; terpinnate.

TRĪPINNNĂT'ǏFID, thrice pinnatifid; thrice pinnately eleft: -said of il piunatificl leaf when its segments are pinnatifid and the subdivisions of these are also pinnatifid.

TRİǏNNĂT'Ǐš̌CT, the same as Tripinnatifid, with the divi- 
sious extending in each case to the base or midrib.

TRĬP LE-NẼRVED， see THREENERYED.

TRIP'LE-RÍBBED, having three prominent ribs or veius.

TRĬP'LICĀTE - GĚM'ǏNĀTE, see Tergeminate.

TRĬP'LĬCĀTE - PǏN'NĀTE, s e e TrIPINNATE.

TRĬP'L ǏCĀTE-TẼ R'NĀTE, s e e TritenNate.

TRĬP'LINẼRVED, see THREENERVED.

TRĬP TẼROǓS, three-winged.

TRIQQUE'TROǓS, prismatic, with three acute or salient angles. Compare Trigoxous.

TRISECT'É divided into three parts or segments by incisions extending to the midrib or base : said of leaves.

TRİŠP'ALOǓS, of three sepals; triphyllous.

TRİŠ̌PTĀTE, having three septa.

TRISÉRIAL, in three rows; triseriate. See ThREE-RANked.

TRĪsÉ'RĪĀTE, see TRISERIAL.

TRISSPẼR'MOŬS, three-seeded.

TRǏS'TǏ€HOŬS, see THREERANKED.

TRĪSTǏGMĂT'ǏC, having three stigmas.

TRǏ'TIS, of some dull or dingy color. (Rare.)

TRĪSTY'Y'LOǓS, having three styles.

TRİSULL'CĀTE, three-grooved.

TRİTẼR'NĀTE, thice ternate. as a compound leaf whose primary petiole divides into three secondary petioles, each of which again divides into three, each division bearing three leaflets.
TRĪVĂL'VŪLAR, see THREEVALVED.

TRǏV'ǏAL NĀME, see SPECIFIC NAME.

TRŐEH'LEAR, short-cylindrical, with the sidles contracted; pulley-shaped; trochleariform.

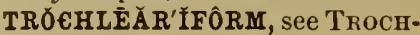
LEAR.

TRǑPH'ŌPLĂST, a term iucluding all essential granules in protoplasm.

TRÓPH'ŌSPẼRM, see PlaAeNTA. TRŬMP'ETT - SHÄPED, tubular, long, very gradually expanded toward the summit, and having a comparatively small and usually but slightly spreadiug limb or border. Compare HYPocRateriforM.

TRỨN'CĀTE, termiuating abruptly, as though cut off or that tened at the end; extremely obtuse. Compare Premorse and Succise.

TRUNK, the stem of a tree.

TRǓSS, a popular uame for a rather compact, moderate-sized, termiual Hower-cluster of any kind, as au umbel, corymb, spike, or raceme.

TR $\overline{\mathbf{Y}}^{\prime} \mathbf{M} \dot{A}$, a drupaceous fruit, like the waluut or hickory-nut. It is distinguished from a drupe by being derived from an in. ferior instead of a superior ovary.

TÜBE, the united portion of a gamopetalous corolla, gamosepalous calyx, or monadelphous androcium; any elongated hollow part or organ.

TÜBE'-FÔRM, see TUBE-SHAPED. TŨ'BĔR, a short, thickened pol'tion of a subterranean branch.

TU' $\bar{U}^{\prime} \mathbf{B} \tilde{R} C L E$, any small, wart-like excrescence, as those upon the rootlets of various Leguminoseæ. 
TŪBẼR'CÜLAR, in the form of a tubercle or having tubercles.

TŪBẼR'CŪLĀTE, having tubercles; tuberculose; tubercular.

TŪBẼR'CŪLĀTĔD, see TÜBERCULATE.

TŨ'BẼRCŪLE, a tuberous root, as in the dahlia. (Obs.)

TŪBẼR'CŪLŌSE, consisting of tubereles; bearing many tubercles; tuberculate.

TŪBẼR'CŪLOŨS, see TUBERCULOSE.

TŪBẼRIF' ẼROǓs, bearing tubers.

TU'BẼRōSE, see TUBERous.

TU' $\bar{U}^{\prime} \mathbf{B E R O U ̌ S , ~ b e a r i n g ~ t u b e r s , ~ a s ~ a ~}$ tuberous plant; resembling a tuber, as tuberous roots.

T'ÜBE'-SHĀPED, tubular aud rather long and wide; about the same as Trumpet-shaped, but may be shorter; tubiform; tubæform; tubeforns; tubate. See Tubular.

TU'BŪLAR, in the form of a tube or pipe; fistular; tubulose. Applied in Compositæ to disk-florets, in distinction from the ligulate florets of the ray; also to any gamopetalous or gamosepalous tlower, especially if the tube is rather long and wide. See TuBESHAPED.

TU'̈'BŨLAR FLō'RĔT, a diskflower in Compositx, when, as is usual, it cliffers from those of the ray in having a small and regular corolla; disk-floret; disk-Hower. Compare Ligulate Fi.olet.

T'̄'BÜLI, pl., see TUBULUs.

TŪBŪLIFLO ROǓs, applied to a head of flowers in Compositæ which bears tubular florets only.

TŨ'BŪLŌsE, see TƯBULAR.

TUU'BŪLǓS (pl. Tū'būlī), (1) one of the cells surrounding the central siphon in Chara ; (2) applied by some to the neck in Pyreuonycetes.

TǓFT'ĔD, see CEsPITOSE.

TŨM ĚS'ÇENT, slightly tumid.

TU'MǏD, somewhat turgid or iutlated.

$\mathbf{T} \bar{U}^{\prime} \mathbf{N}$ IC, any integument or investing layer, as a seed-cont, or a peridium; especially, a membrauous scale of a bulb. or a dry sheatl surrounding one of the lower internodes in certain grasses.

TŪ'N ÍCĀTE, covered with a thin, separable coat or tunic.

TUU'NǏCĀTĔD, see TUNICATE.

TU' N' ǏCĀTĔD BǓLB, a bulb with broad, thin scales wlich form successive overlapping coats, as in the onion; coated bulb. Compare SCALY BulB.

TÛR'BĬNĀTE, top-sluaped: in. versely conical, as the pericalp of water-lilies.

TÛRGĔS'CENT, swelliug; slightly turgicl.

TÛR'GID, (1) thickened as if swollen, like a tuber; (2) distended with liquid, but not with air. Compare INFLATED aud 'umid.

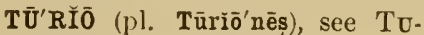
RION.

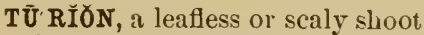
from the ground, as a young stem of asparigus; turio.

TŪRĪONÍF'ẼROUSS, bearing turions.

TURN'ING IN, commencing to head: said of cabbages, etc.

TÛR'NǏP-SHĀPED, see NAPIFOLM.

TÛR'PËNTINE VĚS'SĚLS, see RESIN-PASSAGES.

TŬS'SOCK, a tuft growing from the ground, as in many grasses. 
TWǏN, see Geminate.

TWIN'ǏNG, asceuding by coiling the stem in a spiral manner anound a support; voluble. Compare Climingan.

TWÍsT'ĚD, see CoNToRTED.

TWO '-CLĚFT, see B1FID.

TWO'-FÔRKED, see DrсHоTоMOES.

TWO'-LIYPPED, see LABIATE.

TWỌ'-PÄRTĔD, see BIPARTITE.

TWO ${ }^{\prime}-R A ̌ N K E D$, situated in two rertical rows on opposite sides of the stem, as the leaves of grisses; distichous.

TWO'-TOOTHED, see BIDENTATE. TYY'L.ÖSE, see TYLosis.

TȲLŌ'SǏS (pl. Tylō'sēs), a protrusion from an adjoining cell into the cavity of a vessel, sometimes exhibiting repeated cell-division within the vessel. Sometimes written Thylose and Thyll. A vessel which contains these protrusions is said to exhibit tylosis.

TYYM $\mathbf{M}^{\prime} \mathbf{P A} N$ ŬM, a membrane closing the mouth of the capsule in some mosses.

$T \bar{Y} P E$, a perfect specimen or individual, exemplifying the essential characters of the species or other group to which it belongs.

TYYPE-SPÉC'IMEN, the original specimen from which a botanical description was written and upon which the name of the plant or group is based: the actual individual which serves as the type of a species or other group.

TY̌P'ÍCAL, representing the type or plan.

ŪLǏ́G'ǏNōSE, see PALUSTRINe. ÜLǏG'ÍNOǓs, see PaLUSTRine.
UัM'BĚL, the inflorescence of the order Umbelliferæ. or any Hower-cluster in which several primary rays or pedicels arise from the apex of the stem or peduncle. A typical umbel is somewhat flit-topped, and lias the rays spres.diug like the stays of an umbrella. An umbel is simple when each ray or pedicel bears but a single flower; it is compound when each bears several flowers or secondary rays.

ŬM'BĚL, C̛̆ั'MŌSE, see CYMosE UMBEL.

ŬM'BĚLLĀTE, bearing umbels: pertaining to nmbels; umbellike.

ŬM'BĔLLĀTE ÇȲME, see CrMOSE UMBEL.

ŬM'BĔLLĚT, a small umbel or a partial umbel; umbellule.

ǓMBĚLLǏF' ẼROǓS, produciug unmbels.

ŬMBĚL'LIFF̂RM, in the shape of an umbel.

ŬMBĚL'LŪLĀTE, in the form of a small or a partial umbel. Formerly used for Subumbellate, which see.

ŬM'BĚLLŨLE, see UMBBELLET.

ŬMBĚLLŬLǏF'ẼROŬS, bearing small umbels.

ŬMBǏL'ǏCAL CôRD, see FUNICULUS.

ǓMBÍL'ǏCĀTE, having an umbilicus, or central depression like the navel.

ŬMBÍLI'CŬS, an old term for Hilum: any depression resembling the navel.

ǓM'BŌ, a central elevation, like the boss of an ancient buckler.

ŬM'BŌNĀTE, having a low, rounded central projection, as the cap of many nushrooms. 
UัMBǑN'ŪLĀTE, slightly umbonate; subumbonate; bearing a small, or slightly elevated, umbo.

ŬMBRĂC'ŪLIFÔRM， umbrellashaped.

UัMBRĂC'ŨLŬM, the fruit-cap of Marchuutia, or any such umbrella-shaped appeudage.

ǓNÄRMED', destitute of thorns, spiues, or prickles.

ǓN'CĀTE, see UnCINATE.

ǓN'ÇIFÔRM, look-slıaped.

ŬN'ÇĨNĀTE, lıooked at the end, or furuished with hooked appeudages; uncate; unciform. Compare Falcate.

ǓNC'TUัOǓS, having a greasy appearance.

UัN'DĀTE, see UNDULATE.

UัN'DĀTĚD, see UTDELATE.

UัN'DẼRSHRǓB, (1) a low shrub, less than three feet ligh, as the wintergreen; (2) a plant with woorly base and upper portion herbaceous aud yearly dyiun back, as the gardeu sige (suffrutex). The term is now generally used in the first sense only.

UัN'DŪLĀTE, applied to leaves which have the surface near the margin alternately concave and couvex; undate. Compare Crist, SINUATE, WATED, aUd RUFFLED.

ǓNE'QUAL, (1) unsymmetrical, as the leives of begonia; (2) differing in length-applied to stamens, ete.

ǓNE'QUALLY̌ PǏN'NĀTE, see IMPARIPINNATE.

UัNE'QUAL - SĨDĔD, unsymunetrical.

UัNGUǏC'ÜLAR, see UNGUICULATE.

UัNGUIC' ǓLĀTE, (1) furnished with a "claw" or uuguis, as the petals of piuks; (2) ending in a curved point resembling a claw.

ǓN'GUIFôRM, like the claw of a petal.

UัN'GUǏs, see CLAw.

ǓN'GŪLĀTE, hoof-shaped.

UNI-, a Latin prefix, one.

ŨNĬX̆X̆LL, haviug an unbranched stem.

ŪNY̌CĂP'SŪLAR, having the carpels of a tlower all united into one enIjsule.

ŪN ǏCĂR' ǏNĀTĔD, one-keeled.

UNICĔL'LŪLAR, one-celled.

UNÍCOL'OR, of the same color throughout ; whole-colored ; unieolorous; isochrous. Compare Discolor and C'oxcolor.

UNICCOL'OROǓS, see UNICOLOR.

UNIFA'RİOǓs, o n e - rauked. Compare SEcund.

ŨNǏLLŌ ROǓs, one-tlowered.

ŨNIFŌ'L Ǐ̃TE, one-leaved. Used also fol Uuifoliolate, which see.

ŪNY̌FO'LǏŌLĀTE, of one leaflet, as the theoretieally eompond leaf of the orauge and lemon.

ŪNIJ'ŪGĀTE, having at siugle pair of leatlets or other organs.

ŪNILÁA'BĪĀTE, one - lipped;sometimes applied also to a regular gamopetalous corolla which is open on one side, as the ligulate florets in Compositæe. See LABlAte.

ŨNILÃT'ẼRAL, one-sided. See SECUND.

ŪNILǑC'ŪLAR, one-celled, as applied to anthers and ovaries; elocular.

ǓNǏNTẼRRŬP'TĚD, see CoNTINTOUS.

UNIYP'ÁROǓs, bearing or producing but one stem or axis. 
UNNIYP'ẢROǓS ÇȲME, a cyme with one main axis; monochasium. Compare Dichasium.

ŪNǏPET'ALOǓS, having but one petal, as Amorpha. Compare GaMopetalous.

ŪNǏSĚP'TĀTE, having a single septum.

UNISSE'RİAL, laving one row or whorl; uniseriate. Compare ONE-RANKED.

ŪNISSE'RİATE, arranged in a single line; uniserial.

UNISSEX' vidual or flower which has one kind of sexual organs only; diclinous.

ŪNǏVĂL'VŪLAR, dehiscing along one suture only, so that the pericarp has but one valve, as the pod of the common milkweed, Asclepias Cornuti.

ŪNIVẼR'SAL, see COMMON.

ŪNǏVẼR'SAL ǏN'VŌLŪCRẼ, see Common Involucre.

ŨNǏVẼRSAL ŬM'BĔL, sce CoMPOUND UMBEL.

ŬNLIN'ÍNG, the separation of parts originally united. Formerly used for Chorisis, from the erroneous supposition that the additional organs in chorisis were always produced in this manner. See Chorisis.

ǓNSY̌MMĚT'RǏCAL, not symmetrical, which see.

ÛR'CĒŌLĀTE, pitcher- or urnslatped : tubular, and contracted at the orifice.

$\bar{U} \mathbf{R} \bar{E}^{\prime} \mathbf{D} \overline{0}-\mathbf{F R U N I T}$, a sorus or group of ureduspores.

U RE' DŌSPŌRE, a form of unicellular spore or gonidium in the Uredineæ or rust-fungi, produced earlier in the season than the teleutospores, and destined for immediate germination.
ŪR $\bar{E}^{\prime} D \bar{D}-\mathbf{S T A} G \mathrm{G}$, the early summer stage of the Uredinex, during which only uredo. spores are produced.

ÛRN, the spore-capsule of mosses; also the base of a pyxidium.

ÛRN-SHĀPED, sCe URCEOLATE. ÛRTǏCĀ'ÇEOUS, pertaining to nettles or the family Urticacex.

U'TRǏCLE, (1) a fruit having a small intlated membranous pericarp, as that of Chenopodium; (2) the bladder of various aquatic plants, as Utricularia; (3) one of the large hyaline cells in the leaves of Sphagnum.

U'TRǏCLE， PRIMMÔR'DǏAL， see PIIMOLDIAL UTRICle.

ŨTRĬC ÚLAR， bladder - like or furnished with utricles.

ŪTRĬC'ŪLĀTE, inflated like a bladder; utricular.

U'TRIC'ÚLIF̂̂RM, shaped like a bottle or bladlder; abont the same as Urceolite, but a less definite term.

ŪTRǏC' ŪLŌSE, bearing utricles.

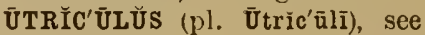
UTRICLE.

VǍC'ŪōLE, a sap-cavity in the protoplasm of a cell.

VÁG'́'NÁ, see SHEATH.

VĂG'INANT, sheathing.

VĂG'ǏNATTLD, shenthed; invaginated.

VÁGINNẼR VōSE', having the small veins (nerves) in no apparent order.

VĀGÍN'ŪLÁ, a small sheath; especially, the apex of the stem which surrounds the base of the seta in mosses; vaginule.

VÁG'ǏNỦLE, see VAGINULA.

VĀGUE, in no definite order or direction; of no definite or 
constant form. Com par e A MORPHOUs.

VĀIL, see VEIL.

VĂLLĚC'ŪLA (pl. Văllěc'ūlæi)，a groove or furrow, as those between the ridges on the fruit of Umbellifere. Compare Sulcus.

VĂLLĔC'ŪLAR CẢNĂLȘ', large intercellular passages, altermating with the fibrovascular bundles in the stem of Equisetum. They are situated in the cortex, and lie between the ridges on the surface. Compare CariNal CANal.

$\mathbf{V}$ ĂL'ĀTE, said of the leaves of a flower iu astivation when they meet at their edges and do not overlap, as the sepals in the rose; valvular. The margius of valvate orgaus may be rolled or folded iuward or outward.

VĂLVE, (1) one of the parts of a dehiscent pericarp; (⿱2) $)$ the lid of an ascidium or pitcher; (3) oue of the halres of a frustule in diatoms.

VĂLV'ÜLAR, see VALTATE.

$\nabla \bar{A}$ 'R ĬALE, said of a species or other group which embraces many individuals which depart more or less from the type of the group. 'The term is applied in a similar way to any organ or character which fails to exhibit uniformity.

VĂRÍ $\bar{A}^{\prime}$ TION, a transient variety, consisting of but one or a few individuals, less marked than a Sport, and usually but slightly differing from the type of the species or variety to which it belongs. It is subordinate in importance to a Form, and less frequently produced by some peculiar condition of the soil or climate.
VÃ'ǏCōsE, appeariug abnormally enlarged in places;applied to hairs and other tubular filaments.

VÁ'RĪEG ĀTĚD, applied to leaves, etc., which have two or more colors upon the surface, especially to such as are permanently marked with white or yellow. Compare Bicolor and CHLOROsis.

VÁR İ'ETY̆, a group subordinate to a species, founded on characters which in cultivated plants are often temporary, and which in the wild state are regarded as permanent, but which gradually merge into those of the main specitic form. Compare SPECIES, RACE, SPORT, and VARiation. VẢRI' $\bar{E} T \breve{Y}-H \bar{Y}^{\prime}$ BRĬD, see CRoss.

VÄR'NǏSH, see BLASTUCOLLA.

VÄR'NǏSHED, see VELNICOSE.

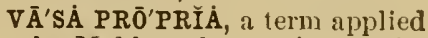
by Mohl to the portion of the phloëm containing the sievetubes and other thin-walled tubular cells. Now seldom used.

VĂS'CŪLAR, pertaining to or contaiving vessels.

VÃs CÜLAR BŬN'DLE, see FIBRovascelar bUNDLE.

VĂS'CŪLAR BŬN'DLE-SHĒATH, a layer of cells between the phloěm and cortex, or surrounding a fibrovascular buudle, or an entire filrovascular cylinder; phloẻm-sheath.

VĂS'CŨLAR CYY̌L'ǏNDẼR, see Fibrotascular Crimder.

VĂS' CŪLAR SY̌S'TĚM, see FIBRoVASCULAR SYSTEM.

VĂS'CŪLAR TǏS'SŪE, see VESSEL. VĂS'CŪLǓM, a botanist's collect. ing-case. Formerly this term wis applied to an ascidium or pitcher-shaped leaf. 
VĀSE'-SHĀPED, shaped somewhat like a comınon flowerpot. (Rare.)

VĂS'ǏFôRM, having the character of ducts or vessels.

VĂS'ǏFÔRM WŌOD-ÇĔLLS, see TracheIds.

VẠULT'ÉD, overarched, as the upper lip of many ringent flowers; fornicate.

V̌́G'ÉTÁBLE, (1) any plaut; (2) in horticulture applied to plauts cultivated for some edible part besides the fruit, and also to some, as the melon family, in which the part used is properly a fruit.

V̌̆G'ẼTÄBLE ȦN ĂT'0̄MY̆, see STRUCTURAl BOTANY.

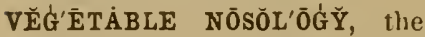
department of vegetable pathology which treats of the diagnosis or classification of the diseases of plants.

VĚG' $\bar{E} T \dot{A B L E}$ PA்THǑL'0̄GY̌, the science which treats of the diseases of plants. It includes the study of disease-producing parasites and of the means for preventing their injuries. It does not include Teratology.

VĔG'ẼTẢBLE PHY̌Š̆ǒL'ŌĠY, see P'UYsiological Botary.

VĚG'ÉTÁBLE TAXXōN'0̄MY̌, the part of systematic botany which relates to the classitication of plants.

V̌́G'ÉTÁBLE WĂX, a wax-like substance upon many leaves and fruits, an important fuuction of which is to protect the parts from excessive moisture. See Bloom.

VĚGẼTÁTION, (1) gelmination and growth; (2) plants in general.

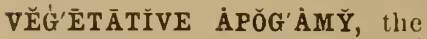
apogamous production of growing shoots in place of seeds or spores. See APogANIY.

VĔG'ẼTĀTǏVE ÇĚLL, a cell in a pollen-grain which does not develop into the pollen-tube. Compare Gexerative Cele.

VĚG ẼTĀTǏVE NÜ'CLẼ Ǔs, any nucleus in a pollen-tube which takes no direct part in fertilization. Compare Gexeliative Nucleus.

VEIL, (1) a membrane connecting the margin of the cap in mushrooms with the stalk; velum; (2) the calyptra in mosses.

VEIN, a small bundle of fibro. vascular tissue within a leaf. When large, and occupying a prominent ridge, it is called rib; when very small it is sometimes called nerve, especially in monocotyledons; but the term Nerve is now little used.

VEIN'LĚT, a small, secondary vein; veinule.

VEIN'ÜLĚT, a branch of a veinlet. (Rare.)

VĒLA' $\bar{A}^{\prime} \mathbf{M E L N}$, an envelope of sev. eral layers of cells containing air, surrounding the aêrial roots of orchids and Aroidex.

V $\overline{\mathbf{E}}^{\prime} \mathbf{L} \overline{\mathbf{A}} \mathbf{T E}$, furuished with a veil; veiled.

VE'LŬM, the membranous indusium in Isoutes. Formerly applied to the veil of mushrooms.

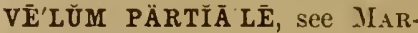
GINAL VEIL.

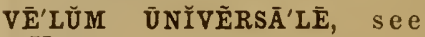
VOLYA.

VĒLÜTĬNOǓS, corered with a close, silky cont of short, fine, erect hairs of even length; velvety.

VĚL'VĚTY̌, sec VELuTINots. 
VẼNÁ'TION, the manuer in which the veins are arranged in a leaf.

VĒNŌSE', containing mumerous veius.

V̌̌N'TẼR, the expanded basal portion of an archegonium, in which the oösphere is formed.

VĔNTRAL, pertaining to the face or front, being the sidle opposite to the dorsal. See Dolisal.

VĔN'TRAL CÁNĂL' ÇĚLL, a small cell below the entrance of the neck of an archegonium, cut off from the mothercell of the oösphere.

VĚN'TRAL SÜ'TŪRE, a line of union between the margins of the carpel or carpels in an ovary. Compare Domsal SuTURE.

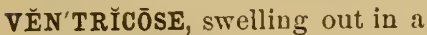
rounded manner.

VĚNTRĬC'ŪLŌSE, slightly ventricose.

VĚNTRICŬM'BENT, face downward upon the ground; prone.

VĚN'ŪLŌSE, abounding in veinlets.

VẼRMǏC'ŨLAR, worm-shaped.

VẼRMÍC'ŨLĀTE, vermicular, or bearing worm-like processes.

VẼR'MǏFôRM BŎD'Y̌, see SCOLECITE.

VẼR'NAL, pertaining to spring; appearing in spring.

VẼRNÁTION, the manner in which leaves are disposed in the bud: prefoliatiou. Sometimes improperly used for Foliatiou, the act or time of leafing.

VẼR'NǏCōSE,appearing asthough varnished, as the butls of many trees.

VĔRRƯ'CA (pl. Věrrụ'çæ), a wartlike elevation of any kiud, in. cluding the sessile apothecia of some lichens. (Obs.) See IVAR'T.

VĔRRU़'C五FôRM, wart-like.

VĚR'RỤCŌSE, wart-like, or bearing wart-like prominences. Compare Papillate and Pustulate.

VĚRRỰ'CŪLōsE, slightly verrucose.

VẼR'SÁTǏLE, attached at one point, so as to swing freely to and fro, as the anthers of the lily.

VẼR'SǏCÓLOR, clangeable in color, or appearing of different colors from different points of view.

VẼR'SǏFôRM, varied or varying in form.

VẼR'TĚX, an upper extremity; summit. Compare APEx.

VĚR'TǏCAL, (1) perpendicular to the horizon; (2) perjendicular to the surface or axis of support; (3) in the direction of the axis of growth; lengthwise.

VẼR'TǏCAL ĂN'THẼR, see Ix̃NATE.

VËR'TǏCAL CHŌ'RĬSǏs, se e Transverse Chorisis.

VẼR'TǏCAL LẼAVES, applied especially to erect leaves like those of Iris. which have no distiuct or obvious dorsal and veutral surfaces.

VẼR'TĬCALLY̌ CŎMPRĔSSED', see DEPRESSED.

VẼR'TǏCAL SY̌S'TĚM, see FIBROvasculali Srstem. Compare HORIZONTAL SYYSTEN.

VẼR'TǏČEL, see VERTICıL. VẼR'TÍC̆IL, see WHORL.

VẼRTICČILLĂS'TẼR, a pair of lense cymes in the axils of opposite leaves, forming an 
apparent verticil, as in most Labiatæ.

VẼRTĬÇ'ǏLLĀTE, arranged iu a ring or whorl; whorled.

VĔS'ICLE, a small bladder-like body or cavity.

VẼSICC'ŪLAR, bearing or containing numerous vesicles; vesiculate; vesiculose.

VËSǏC'ŪLĀTE, see VESICULAR. VẼŠC'ULŌOSE, see VESICULAR.

VĚS'PẼRTǏNE, pertaining to or taking place early in the evening: applied especially to flowers which expand at that time of the clay.

VĔS'SĔL, a cell, or row of confluent cells, having markings produced by thickenings in the cell-wall, forming dots, bauds, rings, spirals, etc. Formerly only vessels having spiral markings were called vessels, in distinction especially from those having pitted walls, which were known as ducts, but the term Duct is now comparatively little used. The terms Duct and Vessel are partially equivalent, Duct being perhaps more often used for coutinuous vessels composed of more than oue cell. See Trachea and Tracheld.

VĚS'TÍBŪLE, a term applied by Duchartre to an opening or chamber above the stomata in certain plants, is Cycas revoluta, formed by the depression of the guard-cells and the outward growth of the adjoining epidermal cells. Compare ANTECHAMBER and STOMATIC CHAMBER.

VĔS'TĬGE, an abortive part which in some ancestral form was fully developed.

VÉT'ẼRAN (Forestry), a very old tree.
VĚX'ǏL, see VEXILLUM.

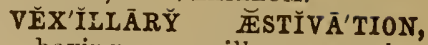
having a vexillum or other sinilar large petal which eufolds all the others in the burl. More properly "Cochlear As. tivation," except in Papilionaceæ.

VĚX'ǏLLĀTE, having a vexillum. VEXIL'LŬM, the large upper petal of a papilionaceous Hower; standard; banner.

VI'ÁBLE, capable of growing or manifesting life-siid maiuly of seeds.

VI'́RRAंTǏLE, having a vibratory or back-aud-forth motion.

VI'BRōǴr. a term applied by Penhallow to certain longitudinal bands of active tissue in the cortex of teudrils to which their movements of circumuutation are supposed to be chiefly due.

VĪCA'RĬoǓs, performing the function, or occupying the place, of some other organ.

VǏL'Li (sing. Vil'lŭs), velutinous hairs.

VǏL'LĬFôRM, resembling villi.

VǏLLŌSE', covered with rather thin, soft, straightish hairs, somewhat finer, softer, and thicker than in Pilose; villous. Sometimes used for Velutinous, which see.

VǏL'LOǓS, see VILLOSE.

VĬL'LŬS, sing., see VILLI.

VI'MĽN, a long, tlexible shoot or branch, like the willow branches used for wickerwork. (Obs.)

VǏM'ǏNAL, pertaining to twigs.

VǏMǏN'Ẽ ǓS, producing or resembling long, flexible twigs or branches.

VINEE, any plant, or its stem, which is incapable of self- 
support, and either grows upon the ground or supports itself upon other objects.

VĪRĚS'ÇENÇE, having petals abnormally green in color, like leaves.

VİRĚS'CSENT, greenish, or becoming green.

VĨR'GĀTE, wand-like; long, straight, and slender.

$\nabla \tilde{I} R^{\prime} G \bar{U} L \bar{A} T E$, diminutive of Virgate; shaped like a little twig or rod.

VǏRIDELS'CoNT, greeuish; virescent.

VİRōSE', having a nauseous odor.

VIS'ČID, sticky; adhesive; viscous.

VǏS'ÇǏD DǏsK, the retinaculum of orchids.

VITTĔL'LŬS, the embryo sac as it appears in the seed.

VİTIC'0̄LOǓS, growing upon the grape-vine, as certain parasitic firngi.

VİTǏC'ŪLA (pl. Vītǐc'ūlæ), a traîling stem, as that of the cucumber; a little vine; a tendril; a stolon; a sarment. (Rare.)

VITTIC'ŨLōsE, bearing or resembling viticule.

VIัT'KËOǓs, transparent like glass. Compare Hraline.

VIT'TA (pl. Vit'tæ), one of the tubular oil-receptacles in the fruit of Umbelliferæ; oil-tube. They appear externally as ridges.

VǏT'TĀTE, bearing vittæ, or longitudinal stripes or ridges somewhat resembling the vittæ on the fruit of Umbellifer:e.

VIVĀCIOǓs, (1) living over win. ter, or from year to year; perennial; (2) full of life; difficult to kill.
VIIVIP'ÁROǓs, producing bulbs or seeds which germinate while still attached to the parent-plant. The term is not applied to the production of ordinary offsets or suckers.

VŏL'ŪBǏLE, see 'TwINING.

VǑL'ŪBLE, see 'TwINING.

VŏLŬNTEER'. A volunteer crop or plant is one which has come from self-sown seed within the boundaries of the field or firm and has grown without care or cultivation. The term implies that the growth is of some value.

VōLŪTE', rolled up in any direction.

VŏL'VÁ, a covering, membranous, gelatinous, or otherwise, which extends from the margin of the cap to the base of the stipe in mushrooms, and which is ruptured by growth in those species which have an elongated stem; wrapper; velum universale.

WALL'ǏNG Ō'VÈR, a term employed in forestry for the growth of a callus over a cut or injured surface.

WART, a sessile gland, hard excrescence, or other protuberance resembling a wart upon animals. Compare Pustule.

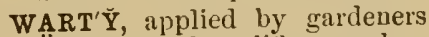
to a head of caulitlower when it becomes loose and covered with small prominences preparatory to throwing up the seed-stalks; frothy.

WA'TẼR-CōRE, an abnormal condition of a part or the whole of the Hesh of the apple, occa. sionally seen, in which the cells are unusually firm, do not lose their fluid contents upon ripen. ing, and appear as though water-soaked. 
WA'TẼR-GLAND, a group of cells beneath the water-pores of certain plants, as in Saxifraga, which serve to facilitate or regulate the transpiration of water. The cells composing the glaud are rich in protoplissm but destitute of chlorophyll.

WA'TẼR-PŌRE, an aperture in the epidermis directly over the extremity of a vein in the leaves of certaiu plants, as Caladium esculentum. It is a stoma whose guard-cells have lost their function aud become immovable, and its probable function is to facilitate the transpiration of water.

WÁ'TẼR-SPROUT (Hort.), an unusually long shoot or limb of one year's growth, especially upon the body of a tree where older limbs have been removed.

WÁ'TẼR-STŌMÁ, see WATERPORE.

WA ${ }^{\prime} T E ̃ R-S T O ̄ R^{\prime I} N G$ TǏS'SŪE, a form of water-tissue addapted for the storage of water for the supply of surrounding cells in times of drought, as in many plants of dry climates.

WĀVED, said of a margiu when strongly undulate, but less strongly than Ruftled.

$\mathbf{W} \bar{A} V^{\prime} \check{Y}$, alteruately concave and convex upon the surface or margin. See Sinuate, REPAND, UNDULATE, and CRISP.

WĚATH'ẼR-PROUD, a garlener's term, employed in England, denoting that plants are larger or more thrifty thau common for the season of the year.

WĚDGE'-SHĀPED, see CUNEATE. WEED, a plant which grows where it is not wanted and which becomes troublesome. Applied chiefly to wild plauts.
WEEP'ǏNG, (1) having the smaller branches so lax that many of them baug directly dowuward, as those of several species of willow; (2) the eopious exudation of sap from water-pores or from an injured surface, in the latter case more often called Bleeding.

WĚFT, a collection of iuterlacing hyphre or other tilaments.

WĚLT, a bload, raised stripe or ridge upon the surface of a fruit, as is occasionally seen in the orange and lemon.

WELLT'ĚD, flaccid; drooping. (Obs.)

WHEEL'-SHĀPED, see Ro'TATE.

WHİP'-SHĀPED, see FLAGELLIFORM.

WHĨRL, see WHORL.

WHôRL, a set of organs arrauged in a cirele around a stem or axis; verticil.

WHÔRLED, see VERTICILLATE.

WĪLD, (1) growing spontaneously without care or cultivation, either native or introdueed; feral; (2) in a natural condition, not improved by cultivation or artificial selection. When used without qualification Wild means strictly native.

WILD'ẼRING, see WILDING.

WILD'ǏNG, (1) a cultivated plant that has "run wild" or reproduced itself spontaueously; wildering; (2) any wild plant; wildling. In both senses applied to fruit-trees. A fruittree, however, which has sprung up spontaneously within cultivated ground is not usually called a Wilding, but merely a "chance seedling."

WING, (1) any thin or membranous appendage, especially a flattened appendage to a seed 
which enables it to be more readily conveyed by the wind, as in the asl and maple; (2) one of the sicle petals of a papilionaceous Hower, as of the pea or bean; ala.

WǏNGED, bearing a membranous expansion or wing; alate.

WǏN'TẼR AN'NŪAL, a plant which germinates in the fall, lives over winter, and produces seed and dies the following season.

WIN'TẼR SPŌRE, see REsTINGSPOLE.

WǏTH'ẼRING, see MIARCESCENT. WOOD, all that portion of the stem in exogens within the bark or cambium layer, except the pith and medullary rays. It consists of the xylem portions of the united tibrovascular bundles. The term is also extended in popular use to all parts of similar texture in plants. See Xrues.

WOOD-FI'BRE, an clongated wood-cell with thick wall and narrow cavity. See BAsTFIBRE.

WOOL, long, dense, curled hairs. WOOLL'LY, see LANATE.

WǑR'ÖNǏN'S H'̄'PHÁ, a coiled hypha in various Ascomycetes, believed to be morphologically an archicarp, but in which fertilization is either wanting or unkmown.

WRĂP'PẼR, see VoLVA.

XÃN THǏC FLOW'ẼRS, those which have yellow for the typical color, including all colors except those containing blue. Compare Cranic FlowERS.

XĂN'THōPHY̌LL, see PhyLloxANTHIN.
XĒNŏG'ẢMY̌, see Cross-FEITILIZATION.

XĒRǑPH'ǏLOǓs, growing in dry climates. (Rare.)

XIPH'ǏOID (vare in botany), see ENsIForM.

XǏPHŏPH Y̌LLOǓS, having ensiform leares. (Rare.)

$\mathbf{X} \bar{Y}^{\prime} \mathbf{L}$ ĚM, the portion of a differentiated fibroviscular bundle which contains the lirger continuous air-containing vessels, and the walls of whose cells are often thickened and liguitied; wood; hadrome. The xylem is separated from another part called Phloèm by the cambium, if there is any, and it usurlly occupies the side of the bundle toward the centre of the stem. Compare PHLÖ̈M.

X $\bar{Y}^{\prime}$ LĚM-PLĀTE, see XYLEM-RAY. $\mathbf{X} \bar{Y}^{\prime} \mathbf{L}$ ĚM-RĀY, a radial plate of xylem between two medullary rays; xylem-plate. Compare PIILOËII-RAY.

XY̌IŌCÄR'POǓs, haviug hard, woody fruit. (Obs.)

XȲLŌ'DǏŬM (obs.), see AcHE. NIUS.

X $\bar{Y} L \bar{O}^{\prime} \mathbf{M} \dot{A}$, a sclerotoid body which produces spores internally: found in Polystigma and some other Ascomycetes.

ZōĂD'ŪLA (pl. Zōăd'ūlæ) (obs.), see ZoösPoRE.

ZŌDǏǑPH ǏLOǓs, pollinated by the agency of auimals, inclid. ing, for example, Protozophilous and Entomophilous. It is the converse of Anthophilous, said of the insects or other auimals which convey the pollen. Compare ANE. MOPHILOTS and HYDROPELLOUS. 
ZŌN'ĀTE, marked with circular, colored bands; zoned. Applied to the tetraspores of Floridex when in a single row, in distinction from a cruciate or tripartite arrangement.

ZŌNE, a circular band or stripe.

ZŌNED, see ZONATE.

ZōōGÁMÉtE, see PLANO. GAMETE.

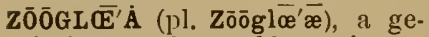
latinous colony of bacteria.

ZōōGōNǏD' ǏŬM (pl. Zōōgōnĩd'íà), a motile gonidium, usually called zoöspore. Restricted by some to a zoöspore which grows into a plant directly, without conjugation. Se e ZOŌSPORE.

Z $\bar{Z}^{\prime}$ ŌSPẼRM, see ZoöSPORE.

ZōōSPŌRĂN'ĞL̆ŬM, a sporangium enclosing zoöspores.

Z $\overline{\mathbf{O}}^{\prime} \overline{0} \mathbf{S P} \overline{\mathrm{R}} \mathrm{R}$, a spore or gonidium having the power of independent movement, isually by means of one or more vibratile cilia; swarm-spore. See ZOÖGONIDIUM.

ZōōTHĒ'CA (obs.), see ZoösPoRANGIUM.

ZYYGōGō'NǏŬM, the female conjugating cell in Conjugater, together with the accessory cells, if any. Compare Ascogonium and Carpogonium.
ZY̌GŌMÔR PHǏC, applied to flowers which are nonosymmetrical, as those of the pea and bean. Compare ActinomorPHic. Sachs exteuds the term to such irregular flowers as are capable of bisection into similar halves in two directions, but in which the halves produced by the two bisections are of different shape, as in Dicentra.

ZY̌GŌMÔR' PHOŬS, see ZYGOMORPHIC.

ZȲGō'sǏs, see CoNJUGation.

ZY̌G ŌSPẼRM, SE ZYGOSPORE.

ZY̌G'ŌSPHĒRE, the female conjugating cell in such zygophytes as bave a distinction in sex. Compare Oösphere.

ZY̌G'ŌSPŌRE, a spore resulting from conjugatiou.

$\mathbf{Z} \bar{Y}^{\prime} \mathbf{G} \bar{O} \mathbf{T E}$, a general term for the product of the union of two gametes.

ZY̌GŌZŌō ŌSPŌRE, a motile zygospore.

ZYYYM'ĀSE, a ferment secreted by certain bacteria; enzyme.

ZYYMŌ'š́s, (1) fermentation of any kind; (2) an infectious or contagious disease.

ZȲMǑT'ǏC, (1) pertaining to fermentation, or caused by organisms capable of producing fermentation; (2) pertaining to an infectious or contagious disease. 


\section{THE AMERICAN SCIENCE SERIES.}

THE principal objects of the series are to supply the lack-in some subjects very great-of authoritative books whose principles are, so far as practicable, illustrated by familiar American facts, and also to supply the other lack that the advance of Science perennially creates, of text-books which at least do not contradict the latest generalizations. The scheme systematically outlines the field of Science, as the term is usually employed with reference to general education, and includes ADVANCED COURSES for maturer college students, BRIEFER COURSES for beginners in school or college, and ElEMENTARY CoURSEs for the youngest classes. The Briefer Courses are not mere abridgments of the larger works, but, with perhaps a single exception, are much less technical in style and more elementary in method. While somewhat narrower in range of topics, they give equal emphasis to controlling principles. The following books in this series are already published:

THE HUMAN BODY. By H. Newell MARTin, Professor in the Johns Hopkins University.

Advanced Course. 8vo. $655 \mathrm{pp}$.

Designed to impart the kind and amount of knowledge every educated person should possess of the structure and activities and the conditions of healthy working of the human body. While intelligible to the general reader, it is accurate and sufficiently minute in details to meet the requirements of students who are not making human anatomy and physiology subjects of special advanced study. The regular editions of the book contain an appendix on Reproduction and Development. Copies without this will be sent when specially ordered.

From the CHICAGo TRIBUNE: "The reader who follows him through to the end of the book will be better informed on the subject of moder physiology in its general features than most of the medical practitioners who rest on the knowledge gained in comparatively antiquated text-books, and will, if possessed of average good judgmen and powers of discrimination, not be in any way confused by state ments of dubious questions or conflicting views." 


\section{THE HUMAN BODY.-Continued.}

\section{Briefer Course. 12mo. $364 \mathrm{pp}$.}

Aims to make the study of this branch of Natural Science a source of discipline to the observing and reasoning faculties, and not merely to present a set of facts, useful to know, which the pupil is to learn by heart, like the multiplication-table. With this in view, the author attempts to exhibit, so far as is practicable in an elementary treatise, the ascertained facts of Physiology as illustrations of, or deductions from, the two cardinal principles by which it, as a department of modern science, is controlled,-namely, the doctrine of the "Conservation of Energy" and that of the "Physiological Division of Labor." To the same end he also gives simple, practical directions to assist the teacher in demonstrating to the class the fundamental facts of the science. The book includes a chapter on the action upon the body of stimulants and narcotics.

From Henry Sewall, Professor of Physiology, University of Michi. gan: "The number of poor books meant to serve the purpose of text-books of physiology for schools is so great that it is well to define clearly the needs of such a work: I. That it shall contain accurate statements of fact. 2. That its facts shall not be too numerous, but chosen so that the important truths are recognized in their true relations. 3. That the language shall be so lucid as to give no excuse for misunderstanding. 4. That the value of the study as a discipline to the reasoning faculties shall be continually kept in view. I know of no elementary text-book which is the superior, if the equal, of Prof. Martin's, as judged by these conditions."

\section{Elementary Course. 12mo. $261 \mathrm{pp}$.}

A very earnest attempt to present the subject so that childrer. may easily understand it, and, whenever possible, to start with familiar facts and gradually to lead up to less obvious ones. The action on the body of stimulants and narcotics is fully treated.

From W. S. Perry, Superintendent of Schools, Ann Arbor, Mich.: "I find in it the same accuracy of statement and scholarly strength that characterize both the larger editions. The large relative space given to hygiene is fully in accord with the latest educational opinion and practice; while the amount of anatomy and physiology comprised in the compact treatment of these divisions is quite enough for the most practical knowledge of the subject. The handling of alcohol and narcotics is, in my opinion, especially good. The most admira. ble feature of the book is its fine adaptation to the capacity of younger pupils. The diction is simple and pure, the style clear and direct, and the manner of presentation bright and attractive." 
AStronomy. By Simon Newcomb, Professor in the Johns Hopkins University, and EDWARD S. HOLDEN, Director of the Lick Observatory.

Advanced Course. 8vo. 512 pp.

To facilitate its use by students of different grades, the subject-matter is divided into two classes, distinguished by the size of the type. The portions in large type form a complete course for the use of those who desire only such a general knowledge of the subject as can be acquired without the application of ad. vanced mathematics. The portions in small type comprise additions for the use of those students who either desire a more detailed and precise knowledge of the subject, or who intend to make astronomy a special study.

From C. A. Young, Professor in Princelon College: "I conclude that it is decidedly superior to anything else in the market on the same subject and designed for the same purpose."

Briefer Course. I2mo. $352 \mathrm{pp}$.

Aims to furnish a tolerably complete outline of the astronomy of to-day, in as elementary a shape as will yield satisfactory returns for the learner's time and labor. It has been abridged from the larger work, not by compressing the same matter into less space, but by omitting the details of practical astronomy, thus giving to the descriptive portions a greater relative prominence.

From THE CRITIC: "The book is in refreshing contrast to the productions of the professional schoolbook-makers, who, having only a superficial knowledge of the matter in hand, gather their material, without sense or discrimination, from all sorts of authorities, and present as the result an indigesta moles, a mass of crudities, not unmixed with errors. The student of this book may feel secure as to the correctness of whatever he finds in it. Facts appear as facts, and theories and speculations stand for what they are, and are worth."

From W. B. Graves, Master Scientific Department of Phillits Academy: "I have used the Briefer Course of Astronomy during the past year. It is up to the times, the points are put in a way to interest the student, and the size of the book makes it easy to go over the subject in the time allotled by our schedule."

From Henry Lefavour, late Teacher of Astronomy, Williston Seminary: "The impression which I formed upon first examination, that it was in very many respects the best elementary text-book on the subject, has been confirmed by my experience with it in the class. room." 


\section{zOOLOGY, By A. S. PACKARD, Professor in Brown Univer-} sity.

\section{Advanced Course, 8vo. $719 \mathrm{pp}$.}

Designed to be used either in the recitation-room or in the laboratory. It will serve as a guide to the student who, with a desire to get at first-hand a general knowledge of the structure of leading types of life, examines living animals, watches their movements and habits, and finally dissects them. He is presented first with the facts, and led to a thorough knowledge of a few typical forms, then taught to compare these with others, and finally led to the principles or inductions growing out of the facts.

From A. E. VerriLl, Professor of Zoology in Yale College: "The general treatment of the subject is good, and the descriptions of structure and the definitions of groups are, for the most part, clear, concise, and not so much overburdened by technical terms as in sev. eral other manuals of structural zoology now in use."

\section{Briefer Course, I2mo. $33+\mathrm{pp}$.}

The distinctive characteristic of this book is its use of the object method. The author would have the pupils first examine and roughly dissect a fish, in order to attain some notion of vertebrate structure as a basis of comparison. Beginning then with the lowest forms, he leads the pupil through the whole animal kingdom until man is reached. As each of its great divisions comes under observation, he gives detailed instructions for dissecting some one animal as a type of the class, and bases the study of other forms on the knowledge thus obtained.

From Herbert Osborn, Professor of Zoology, Iowa Agricultural College: "I can gladly recommend it to any one desiring a work of such character. While I strongly insist that students should study animals from the animals themselves, - a point strongly urged by Prof. Packard in his preface,-I also recognize the necessity of a reliable text-book as a guide. As such a guide, and covering the ground it does, I know of nothing better than Packard's."

First Lessons in Zoology. $12 \mathrm{mo} .290 \mathrm{pp}$.

In method this book differs considerably from those mentioned above. Since it is meant for young beginners, it describes but few types, mostly those of the higher orders, and discusses their relations to one another and to their surroundings. The aim, however, is the same with that of the others; namely, to make clear the general principles of the science, rather than to fill the pupil's mind with a mass of what may appear to nim unrelated facts. 
PSYCHOLOCY_Advanced Course. By William JAMES, Professor in Harvard University. 2 vols. 8vo., 689, 704 pp.

From Prof. E. H. GrifFin, John Hopkins University: "An important contribution to psychological science, discussing its present aspects and problems with admirable breadth, insight, and independence."

From Prof. JoHn Dewey, University of Michigan: " A remarkable union of wide learning, originality of treatment, and, above all, of never-failing suggestions. To me the best treatment of the whole matter of advanced psychology in existence. It does more to put psychology in scientific position both as to the statement of established results and a stimulating to further problems and their treatment, than any other book of which I know."

From Hon. W. T. HARRIS, National Bureau of Education: "I have never seen before a work that brings together so fully all of the labors, experimental and analytic, of the school of physiological psychologists."

Botany. By Charles E. Bessey, Professor in the University of Nebraska.

\section{Advanced Course. 8vo. 6II pp.}

Aims to lead the student to obtain at first-hand his knowledge of the anatomy and physiology of plants. Accordingly, the presentation of matter is such as to fit the book for constant use in the labaratory, the text supplying the outline sketch which the student is to fill in by the aid of scalpel and microscope.

From J. C. Arthur, Editor of The Botanical Gazctte: "The first botanical text-book issued in America which treats the most important departments of the science with anything like due consideration. This is especially true in reference to the physiology and histology of plants, and also to special morphology. Structural Botany and classification have up to the present time monopolized the field, greatly retarding the diffusion of a more complete knowledge of the science."

Essentials of Botany, $12 \mathrm{mo} .292 \mathrm{pp}$.

A guide to beginners. Its principles are, that the true aim of botanical study is not so much to seek the family and proper names of specimens as to ascertain the laws of plant structure and plant life; that this can be done only by examining and dissecting the plants themselves; and that it is best to confine the attention to a few leading types, and to take up first the simpler and more easily understood forms, and afterwards those whose structure and functions are more complex.

From J. T. Rothrock, Professor in the University of Pennsylvania: "There is nothing superficial in it, nothing needless introduced, nothing essential left out. The language is lucid; and, as the crowning merit of the book, the author has introduced throughout the volume 'Practical Studies,' which direct the student in his effort to see for himself all that the text-book teaches." 


\section{Chemistry. By Ira Remsen, Professor in the Johns Hop* kins University.}

Advanced Course. 8 vo.

The general plan of this work will be the same with that of the Briefer Course, already published. But the part in which the members of the different families are treated will be considerably enlarged. Some attention will be given to the lines of investigation regarding chemical affinity, dissociation, speed of chemical action, mass action, chemical equilibrium, thermochemistry, etc. The periodic law, and the numerous relations which have been traced between the chemical and physical properties of the elements and their positions in the periodic system will be specially emphasized. Reference will also be made to the subject of the chemical constitution of compounds, and the methods used in determining constitution.

Introduction to the Study of Chemistry. I2mo. $389 \mathrm{pp}$.

The one comprehensive truth which the author aims to make clear to the student is the essential nature of chemical action. With this in view, he devotes the first 208 pages of the book to a carefully selected and arranged series of simple experiments, in which are gradually developed the main principles of the subject. His method is purely inductive; and, wherever experience has shown it to be practicable, the truths are drawn out by pointed questions, rather than fully stated. Next, when the student is in a position to appreciate it, comes a simple account of the theory of the science. The last $\left.15^{\circ}\right)$ pages of the book are given to a survey, fully illustrated by experiments, of the leading families of inorganic compounds.

From Arthur W. Wright, Professor in Yale College :-The student is not merely made acquainted with the phenomena of chemistry, but is constantly led to reason upon them, to draw conclusions from them, and to study their significance with reference to the processes of chemical action - a course which makes the book in a high degree disciplinary as well as instructive.

From Thos. C. Van Nuys, Professor of Chemistry in the Indiana University:-It seems to me that Remsen's "Introduction to the Study of Chemistry" meets every requirement as a text or class book.

From C. Les MeEs, Professor of Chemistry in the Ohio University: -I unhesitatingly recommend it as the best work as yet published for the use of beginners in the study. Having used it, I feel justified in saying this much. 


\section{CHEMISTRY - Continued.}

\section{Elements of Chemistry. 12mo. $272 \mathrm{pp}$.}

Utilizes the facts of every-day experience to show what chem. istry is and how things are studied chemically. The language is untechnical, and the subject is fully illustrated by simple experiments, in which the pupil is led by questions to make his own inferences. The author has written under the belief that "a rational course in chemistry, whether for younger or older pupils, is something more than a lot of statements of facts of more or less importance; a lot of experiments of more or less beauty; or a lot of rules devised for the purpose of enabling the pupil to tell what things are made of. If the course does not to some extent help the pupil to think as well as to see it does not deserve to be called rational."

Chase Palmer, Professor in the State Normal School, Salem, Mass.: -It is the best introduction to chemistry that I know, and I intend to put it into the hands of my pupils next Fall.

A. D. Gray, Instructor in Springfield (Mass.) High School :-Neat, attractive, clear, and accurate, it leaves little to be desired or sought for by one who would find the best book for an elementary course in our High Schools and Academies.

General Biology. By William T. Sedgwick, Professor in the Mass. Institute of Technology, and EDMUND B. WILson, Professor in Bryn Mawr College. Part 1. 8vo. 193 pp.

This work is intended for college and university students as an introduction to the theoretical and practical study of biology. It is not zoology, botany, or physiology, and is intended not as a substitute, but as a foundation, for these more special studies. In accordance with the present obvious tendency of the best elementary biological teaching, it discusses broadly some of the leading principles of the science on the substantial basis of a thorough examination of a limited number of typical forms, including both plants and animals. Part First, now published, is a general introduction to the subject illustrated by the study of a few types. Part Second will contain a de. tailed survey of various plants and animals.

W. G. Farlow, Professor in Harvard University, Cambridge, Mass.: -An introduction is always difficult to write, and I know no work in which the general relations of plants and animals and the cell-struc ture have been so well stated in a condensed form. 


\section{POLITICAL ECONOMY. By Francis A. WALKer, President} of the Massachusetts Institute of Technology.

Advanced Course. 8vo. 537 pp.

The peculiar merit of this book is its reality. The reader is brought to see the application of the laws of political economy to real facts. He learns the extent to which those laws hold good, and the manner in which they are applied. The subject is divided, as usual, into the three gręat branches of production, exchange, and distribution. An interesting and suggestive "book" on consumption is added, which serves to bring in conveniently the principles of population. The last part of the volume is given to the consideration of various practical applications of economic principles.

From Richmond Mayo Smith, Professor in Columbia College, $N$. Y.:-In my opinion it is the best text-book of political economy that we as yet possess.

From Woodrow Wilson, Professor in Princeton University, $N . J .:$ -It serves better than any other book I know of as an introduction to the most modern point of view as to economical questions.

Briefer Course. I2mo. 4I $5 \mathrm{pp}$.

The demand for a briefer manual by the same author for the use of schools in which only a short time can be given to the subject has led to the publication of the present volume. The work of abridgment has been effected mainly through excision, although some structural changes have been made, notably in the parts relating to distribution anci consumption.

From Alexander Johnston, late Professor in Princeton University, N. J.:-Using the "Briefer Course" as a text-book, suited to any capacity, I am able at the same time to recommend the "Advanced Course" to those who are better able to use it as a book of reference, or more inclined to carry their work further.

Elementary Course. I2mo. $323 \mathrm{pp}$.

What has been attempted is a clear arrangement of topics; a simple, direct, and forcible presentation of the questions raised; the avoidance, as far as possible, of certain metaphysical distinctions which the author has found perplexing; a frequent repetition of cardinal doctrines, and especially a liberal use of concrete illustrations, drawn from facts of common experience or observation.

\section{HENRY HOLT \& CO., PUBLISHERS, N. Y.}





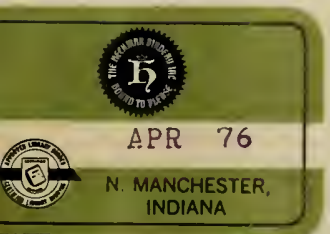




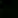

